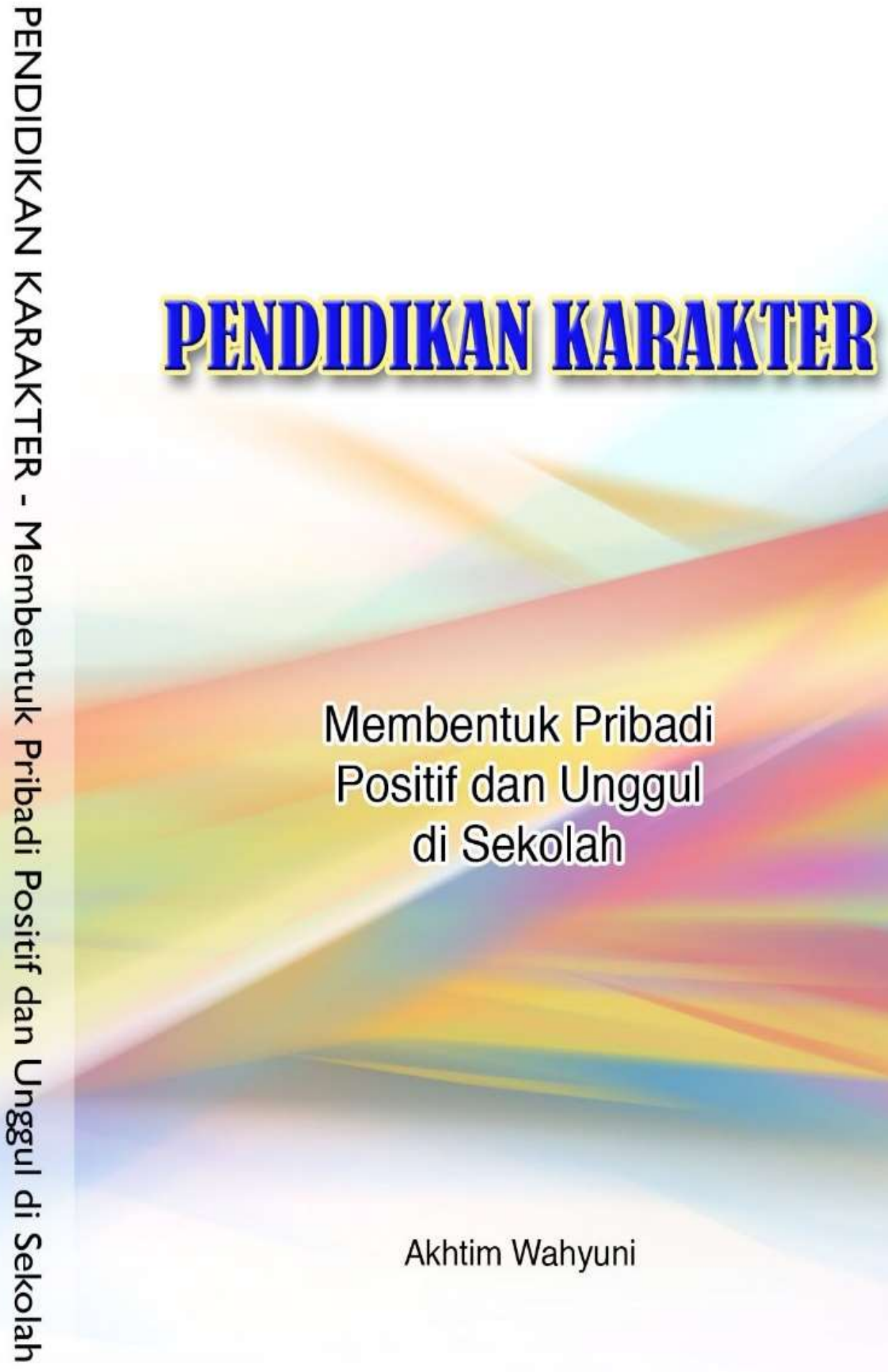




\section{PENDIDIKAN KARAKTER}

Penulis:

Akhtim Wahyuni

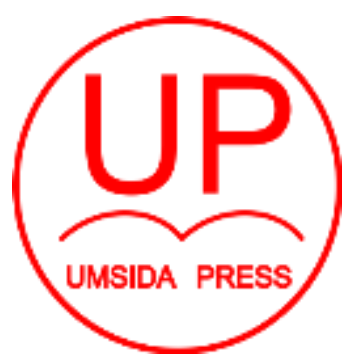

Diterbitkan oleh UMSIDA PRESS

JI. Mojopahit 666 B Sidoarjo

ISBN: 978-623-6292-78-5

Copyright $@ 2021$

Authors

All rights reserved 


\section{Pendidikan Karakter}

\section{Penulis :}

Akhtim Wahyuni

\section{ISBN :}

978-623-6292-78-5

\section{Editor :}

Eni Fariyatul Fahyuni

\section{Copy Editor :}

Fika Megawati

\section{Design Sampul dan Tata Letak :}

Eka Sri Rahmawati

\section{Penerbit :}

UMSIDA Press

\section{Redaksi :}

Universitas Muhammadiyah Sidoarjo

Jl. Mojopahit No 666B

Sidoarjo, Jawa TImur

Cetakan pertama, Desember 2021

(C) Hak cipta dilindungi undang-undang

Dilarang memperbanyak karya tulis ini dengan suatu apapun tanpa ijin tertulis dari penerbit. 


\section{KATA PENGANTAR}

Puji syukur kepada Allah Swt. atas limpahan rahmat dan kasih sayangNya sehingga penulis bisa menyelesaikan buku 'Pendidikan Karakter 'Membentuk Pribadi Positif dan Unggul di Sekolah' ini dan dapat terbit untuk memperkaya referensi tentang Pendidikan Karakter.

Pendidikan karakter menjadi tema penting saat ini untuk mengatasi persoalan-persoalan sosial yang kerap melanda negara ini. Ia menjadi alternatif solusi yang perlu dilestarikan dalam kehidupan sehari-hari. Tidak terkecuali di lembaga pendidikan, yang notabene sebagai wadah penggodokan tiga ranah tingkah laku; kognitif, afektif, dan psikomotorik. Sekolah dipandang sebagai lahan yang efektif untuk membentuk pribadi positif anak, setelah keluarga. Pribadi positif yang terbangun dari proses pembiasaan karakter di sekolah diantaranya: Mampu menilai diri sendiri secara realisitik, Menerima tanggung jawab, kemandirian, dapat mengontrol emosi, berorientasi tujuan, penerimaan sosial, berbahagia, dan lainnya. Ini semua dapat terwujud jika semua stakeholder dilibatkan untuk mengawal dan menjalankan, dan mengevaluasi semua proses ini sehingga menjadi budaya positif di sekolah.

Buku Pendidikan Karakter ini melengkapi buku-buku yang telah ada, untuk memperkaya konsep dan wawasan tentang Pendidikan Karakter. Pengalaman penulis di dunia pendidikan dan sebagai tenaga pengajar di Perguruan Tinggi serta peneliti 
dalam bidang pendidikan dan sosial banyak memberikan kontribusi dalam penulisan, sehingga buku ini terwujud.

Penulis menyadari bahwa buku ini masih banyak kekurangan baik dari sisi konseptual maupun aplikasi. Oleh karena itu, kritik dan saran konstruktif selalu penulis harapkan untuk kesempurnaan buku ini. Tidak lupa penulis sampaikan terima kasih kepada semua pihak yang telah membantu dalam berbagai bentuk demi terselesaikannya buku ini. Semoga buku ini bermanfaat bagi para pembaca.

Sidoarjo, Oktober 2021

Penulis

Akhtim Wahyuni

\section{DAFTAR ISI}

KATA PENGANTAR .................................................................

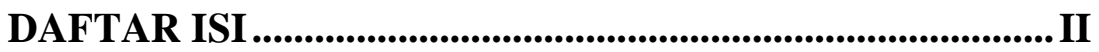




\section{BAB I PENDIDIKAN KARAKTER DAN RUANG}

LINGKUPNYA...................................................................... 1

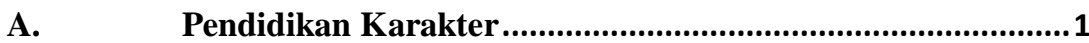

B. Hakikat Pendidikan Karakter ............................................9

C. Fungsi dan Tujuan Pendidikan Karakter ............................13

D. Strategi Pelaksanaan Pendidikan Karakter ..........................17

E. Ruang Lingkup dan Komponen-Komponen Pendidikan

Karakter 23

BAB II PELAKSANAAN PENDIDIKAN KARAKTER .... 26

A. Pendididikan Karakter di Sekolah .......................................26

B. Pendidikan Karakter dalam Keluarga ………………….......59

BAB III SUMBER NILAI-NILAI PENDIDIKAN

KARAKTER ................................................................................. 74

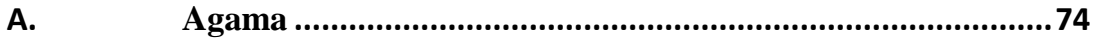

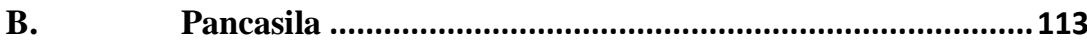

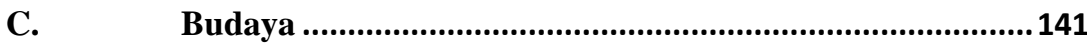

D. Tujuan Pendidikan Nasional..............................................185

BAB IV FAKTOR-FAKTOR YANG MEMPENGARUHI

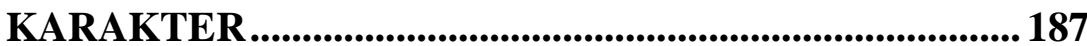

A. Faktor Internal .............................................................187

B. Faktor Eksternal................................................................189

C. Tantangan-Tantangan Pendidikan Karakter.......................190

D. Pendidikan Karakter di Era Digital ....................................198

E. Tantangan Dalam Implementasi di Sekolah.......................202

F. Solusi ...................................................................................211

BAB V EVALUASI PENDIDIKAN KARAKTER ............. 213 A. Tim Penilai ........................................................................214 


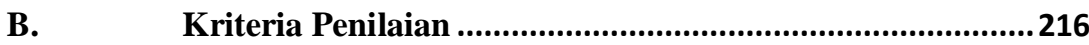

C. $\quad$ Evaluasi Pendidikan Karakter...........................................218

BAB VI MEMBANGUN KARAKTER POSITIF DALAM PEMBELAJARAN ............................................................... 225

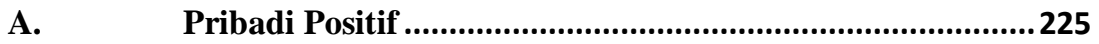

B. Integrasi Pendidikan Karakter dalam Kurikulum

Sekolah 232

BAB VII CARING DALAM PEMBELAJARAN ............. 242

A. Caring Guru dalam Pembelajaran.......................................242

B. Urgensi Caring dalam Pembelajaran ..............................245

C. Caring Relationship sebagai Pembentukan Karakter Anak

Didik Dalam Tradisi Pembelajaran Jawa ...........................................252

D. Caring Relationship sebagai Salah Satu Bentuk Pendidikan

Karakter 258

E. Membangun Pendidikan Karakter Integratif .....................265

BAB VIII KOMUNIKASI VERBAL DAN NON VERBAL DALAM PEMBELAJARAN ....................................... 269

A. Komunikasi Verbal dan Non Verbal Pembelajaran ...........270

B. Komunikasi Non Verbal dalam Pembelajaran ..................275

C. Komunikasi Verbal dalam Pembelajaran .........................283

BAB IX KOMUNIKASI INTERPERSONAL DALAM PEMBELAJARAN .................................................... 285

A. Pengertian Komunikasi Interpersonal.................................285

B. Komunikator yang Mendidik untuk Penguatan Karakter

Siswa $\quad 289$

C. Komunikasi Pendidikan 294 
DAFTAR PUSTAKA ......................................................... 298 TENTANG PENULIS .............................................................. 306 


\section{BAB I}

\section{PENDIDIKAN KARAKTER DAN RUANG LINGKUPNYA}

\section{A. Pendidikan Karakter}

1. Pengertian Karakter

Secara etimologis, kata karakter (Inggris: character) berasal dari bahasa Yunani, yaitu charassein yang berarti "to engrave"(Kevin Ryan \& Karen E. Bohlin, 1999). Makna ini dapat dikaitkan dengan persepsi bahwa karakter adalah lukisan jiwa yang termanifestasi dalam perilaku. Karakter dalam Kamus Besar Bahasa Indonesia diartikan dengan "tabiat, sifat-sifat kejiwaan, akhlak atau budi pekerti yang membedakan seseorang dengan yang lain, dan watak (Pusat Bahasa Departemen Pendidikan Nasional, 2008). Orang berkarakter berarti orang yang berkepribadian, berperilaku, bersifat, bertabiat, atau berwatak. Makna seperti itu menunjukkan bahwa karakter identik dengan kepribadian atau akhlak.

Kepribadian merupakan ciri atau karakteristik atau sifat khas dari diri seseorang yang bersumber dari bentukan-bentukan yang diterima dari lingkungan, misalnya keluarga pada masa kecil, dan juga bawaan sejak lahir (Doni A. Koesoema, 2007). 
Seiring dengan pengertian ini, ada sekelompok orang yang berpendapat bahwa baik buruknya karakter manusia sudah menjadi bawaan dari lahir. Jika jiwa bawaan baik, maka manusia itu akan berkarakter baik, dan sebaliknya jika bawaan jelek, maka manusia itu akan berkarakter jelek. Jika pendapat ini benar, maka pendidikan karakter tidak ada gunanya, karena tidak akan mungkin mengubah karakter orang yang sudah taken for granted. Sementara itu sekelompok orang berpendapat berbeda, bahwa karakter dapat dibentuk dan diupayakan, sehingga pendidikan karakter menjadi sangat bermakna untuk membuat manusia memiliki karakter yang baik. Karakter adalah kepribadian ditinjau dari titik tolak etis atau moral. Karakter memiliki kesamaan arti dengan moral. Moral merupakan kondisi pikiran, perasaan, ucapan, dan perilaku manusia yang terkait dengan nilainilai baik dan buruk( Jamal Ma'mur Asmani, 2011). Menurut Simon Philips bahwa karakter adalah kumpulan tata nilai yang menuju pada suatu sistem, yang melandasi pemikiran, sikap, dan perilaku yang ditampilkan (Masnur Muslich, 2011).

Berdasarkan pengertian di atas dapat dipahami bahwa karakter identik dengan akhlak, etika, dan moral, sehingga karakter merupakan nilai-nilai perilaku manusia 
yang universal meliputi seluruh aktivitas manusia, baik dalam rangka berhubungan dengan Tuhan, dengan dirinya, dengan sesama manusia, maupun dengan lingkungannya, yang terwujud dalam pikiran, sikap, perasaan, perkataan, dan perbuatan berdasarkan norma-norma agama, hukum, tatakrama, budaya, dan adat istiadat. Ahmad Amin menjadikan kehendak (niat) sebagai awal terjadinya akhlak (karakter) pada diri seseorang, jika kehendak itu diwujudkan dalam bentuk pembiasaan sikap dan perilaku (Ahmad Amin, 1995).Fatchul Mu'in dalam bukunya Pendidikan Karakter: Kontruksi Teoretik \& Praktik menjelaskan ciri-ciri karakter, yaitu: (1) Karakter adalah "siapakah dan apakah kamu saat orang lain sedang melihat kamu" (character is what you are when nobody is looking). Jadi, karakter berhubungan dengan konsep diri bahwa seseorang harus paham terhadap dirinya sendiri, harus tahu kelebihan dan kekurangan yang dimiliki;(2) Karakter merupakan hasil nilai-nilai dan keyakinan-keyakinan (character is the result of values and beliefs). Nilai adalah sesuatu yang dianggap benar dan suci, tetapi bersifat abstrak yang hanya dapat dirasakan, sedangkan keyakinan adalah kulminasi dari sesuatu yang dianggap benar dan suci; (3) Karakter adalah sebuah kebiasaan yang menjadi sifat alamiah kedua (character is a habit that becomes second nature). Kebiasaan adalah sesuatu yang 
dilakukan setiap hari, jadi karena sudah menjadi suatu kebiasaan maka ia tampak alamiah dan bukan rekayasa; (4) Karakter bukanlah reputasi atau apa yang dipikirkan oleh orang terhadapmu (character is not reputation or what others thinks about you). Jadi karakter tidak selalu menjadi gambaran diri seseorang berdasarkan persepsi orang lain, tetapi perilaku yang apa adanya; (5) Karakter bukanlah seberapa baik kamu daripada orang lain (character is not how much better you are than others). Jadi karakter bukanlah menjadi perbandingan antara diri seseorang dengan orang lain;(6) Karakter tidak relatif (character isnot relative). Jadi karakter itu adalah baku "saya adalah saya","kamu adalah kamu”, dan "dia adalah dia” (Fatchul Mu'in, 2011).Tampak bahwa semua ciri karakter di atas merujuk pada satu tujuan yaitu menjadi diri sendiri(be your self). Dari konsep karakter ini muncul konsep pendidikan karakter (character education).

Terminologi pendidikan karakter mulai dikenalkan sejak tahun 1900-an. Thomas Lickona dianggap sebagai pengusungnya, terutama ketika ia menulis buku yang berjudul The Return of Character Education dan kemudian disusul bukunya, Educating for Character: How Our School Can Teach Respect and Responsibility. Melalui buku-buku itu, ia 
menyadarkan dunia Barat akan pentingnya pendidikan karakter. Pendidikan karakter menurut Lickona mengandung tiga unsur pokok, yaitu mengetahui kebaikan (knowing the good), mencintai kebaikan (loving the good), dan melakukan kebaikan (doing the good) (Thomas Lickona, 1991). Artinya, karakter mengacu kepada serangkaian pengetahuan, sikap, dan motivasi, serta perilaku dan keterampilan.

Konfigurasi pendidikan karakter dalam konteks totalitas proses psikologis dan sosial-kultural tersebut dikelompokkan dalam: olah hati (spiritual and emotional development), olah pikir (intellectual development), olah raga dan kinestetik (physical and kinestetic development), dan olah rasa dan karsa (affective and creativity development) (Muhammad Yaumi, 2012). Pengembangan dan implementasi pendidikan karakter yang dilakukan semestinya mengacu pada olah hati, olah pikir, olah raga, dan olah rasa tersebut.

2. Pengertian Pendidikan Karakter

Pengertian pendidikan karakter menurut Kemendiknas, yaitu pendidikan yang mengembangkan nilai-nilai budaya dan karakter bangsa pada diri peserta didik sehingga mereka memiliki nilai dan karakter sebagai karakter dirinya, menerapkan nilai-nilai 
tersebut dalam kehidupan dirinya, sebagai anggota masyarakat, dan warga negara yang religius, nasionalis, produktif dan kreatif.9 Dalam buku lain, Kemendiknas juga menyebutkan bahwa pendidikan karakter adalah usaha menanamkan kebiasaankebiasaan yang baik (habituation) sehingga peserta didik mampu bersikap dan bertindak berdasarkan nilai-nilai yang telah menjadi kepribadiannya. Dengan kata lain, pendidikan karakter yang baik harus melibatkan pengetahuan yang baik (moral knowing), perasaan yang baik atau loving good (moral feeling) dan perilaku yang baik (moral action) sehingga terbentuk perwujudan kesatuan perilaku dan sikap hidup peserta didik.10 Saptono dalam bukunya dimensi-dimensi pendidikan karakter mengemukakan pendidikan karakter adalah upaya yang dilakukan dengan sengaja untuk mengembangkan karakter yang baik berlandaskan kebijakan-kebijakan inti yang secara objektif baik bagi individu maupun masyarakat. Menurut Lickona pendidikan karakter adalah upaya yang sungguh-sungguh untuk membantu seseorang memaham, peduli, dan bertindak dengan landasan inti nilai- nilai etis yang dirancang secara sengaja untuk memperbaiki karakter siswa. Karakter memiliki tiga bagian yang saling berhubungan, yaitu pengetahuan moral, perasaan moral, dan perilaku moral. Karakter yang baik terdiri dari mengetahui 
hal-hal yang baik, menginginkan hal-hal yang baik, dan melakukan kebiasaan hal-hal yang baik, kebiasaan dalam berpikir, kebiasaan dalam hati, dan kebiasaan dalam tindakan. Menururt Scerenko dalam buku Muchlas Samani dan Hariyanto yang berjudul Konsep dan Model Pendidikan Karakter, pendidikan karakter dapat dimaknai sebagai upaya yang sungguhsungguh dengan cara mana ciri kepribadian positif dikembangkan, didorong, dan diberdayakan melalui keteladanan serta praktik scara maksimal untuk mewujudkan hikmah dari apaapa yang diamati dan dipelajari. Pendapat lain Dharma Kesuma dalam bukunya Pendidikan Karakter; Kajian Teori dan Praktik di Sekolah menyebutkan bahwa pendidikan karakter merupakan pendidikan yang terintegrasi dengan pembelajaran yang terjadi pada semua mata pelajaran, diarahkan pada penguatan dan pengembangan perilaku peserta didik secara utuh. Penguatan dan pengembangan perilaku didasari oleh nilai yang dirujuk sekolah atau Lembaga.

Menurut Sabar Budi Raharjo dalam jurnal Pendidikan dan Kebudayaan menyebutkan pendidikan karakter adalah proses pendidikan secara holistik yang menghubungkan dimensi moral dengan ranah sosial dalam kehidupan peserta didik sebagai pondasi bagi terbentuknya generasi yang berkualitas yang mampu 
hidup mandiri dan memiliki prinsip suatu kebenaran yang dapat dipertanggung jawabkan. Pendidikan karakter dipahami sebgai upaya penanaman kecerdasan dalam berpikir, penghayatan dalam bentuk sikap, dan pengalaman dalam bentuk perilaku yang sesuai dengan nilai-nilai luhur yang menjadi jati dirinya diwujudkan dalam interaksi dengan dengan Tuhannya, diri sendiri, antar sesama, dan lingkungannya. Nilai-nilai lihur tersebut antara lain, kejujuran, kemandirian, sopan santun, kemuliaan sosial, kecerdasan berpikir termasuk kecerdasan intelektual, dan berpikir logis.

Berdasarkan pengertian di atas dan definisi dari beberapa ahli dapat disimpulkan bahwa pendidikan karakter adalah sistem penanaman nilai-nilai karakter kepada peserta didik sehingga mereka menerapkan dalam kehidupannya baik di keluarga, sekolah, masyarakat, dan negara sehingga dapat memberi kontribusi yang positif kepada lingkungannya. Peserta didik dituntun untuk menjadi manusia seutuhnya yang berkarakter dalam dimensi hati, pikir, raga, serta rasa dan karsa. Dengan demikian, pendidikan karakter adalah segala upaya yang dilakukan oleh guru, yang mampu mempengaruhi karakter peserta didik. Guru membantu membentuk watak peserta didik. Hal ini mencakup keteladanan bagaimana guru berperilaku, cara 
guru berbicara atau menyampaikan materi, bagaimana guru bertoleransi dan berbgai hal terkait lainnya.

\section{B. Hakikat Pendidikan Karakter}

Pendidikan adalah suatu usaha terencana memanusiakan manusia dalam proses sosialisasi untuk memperbaiki karakter serta melatih kemampuan intelektual peserta didik dalam rangka mencapai kedewasaannya. Hal tersebut sejalan dengan pendapat Kadir bahwa, "Pendidikan merupakan usaha terencana untuk memanusiakan manusia melalui sosialisasi untuk memperbaiki karakter dan melatih kemampuan intelektual peserta didik"

Istilah Pendidikan dalam Islam dikenal dengan sebutan "Tarbiyah yang berarti pendidikan, al-ta'lim yang berarti pengajaran, dan al-ta'dib yang diartikan pendidikan sopan santun". Maka jelaslah bahwa, pendidikan berorientasi pada mendidik dan mengajarkan secara sadar tentang nilai-nilai sopan santun dalam hidup bermasyarakat melalui proses sosialisasi.

Sedangkan karakter adalah akhlak yang melekat daam diri seseorang, yang dimulai dengan kesadaran seseorang pada keseluruhan tata perilaku dalam cara berpikir dan bertindak berdasarkan moral yang berlaku melalui pendidikan dengan pembiasaan yang melatih kepekaan peserta didik terhadap nilai- 
nilai moral di lingkungan tempat tinggalnya. Dengan demikian, karakter dianggap sebagai suatu kesadaran batin yang menjadi tipikal seseorang dalam berpikir dan bertindak.

Dengan demikian, pendidikan karakter merupakan suatu usaha sadar untuk menanamkan dan mengembangkan nilai-nilai kebaikan dalam rangka memanusiakan manusia, untuk memperbaiki karakter dan melatih intelektual peserta didik, agar tercipta generasi berilmu dan berkarakter yang dapat memberikan kebermanfaatan bagi lingkungan sekitar. Hal tersebut, sejalan dengan Zubaedi bahwa, "Character education is the deliberate effort to cultivate virtue that is objectively good human qualities that are good for the individual person and good for the whole society".

Pendapat di atas, diperkuat juga oleh pernyataan Lickona dalam Easterbrooks \& Scheets bahwa, "Character education is the deliberate effort to develope virtues that are good for the individual and good for society". Dengan demikian, jelaslah bahwa pendidikan karakter merupakan sebuah upaya yang disengaja secara sistematis untuk mengembangkan kebajikan yang berdampak positif baik bagi individu maupun lingkungan sosial, dan prosesnya tidak instan, melainkan melalui usaha yang terus menerus (pembiasaan). 
Dalam Undang-Undang Republik Indonesia No. 20 Tahun 2003 tentang sistem Pendidikan Nasional Bab I Pasal 1 dinyatakan bahwa pendidikan adalah usaha sadar dan terencana untuk mewujudkan suasana belajar dan proses pembelajaran agar peserta didik secara aktif mengembangkan potensi dirinya untuk memiliki kekuatan spiritual keagamaan, pengendalian diri, kepribadian, kecerdasan, akhlak mulia, serta keterampilan yang diperlukan dirinya, masyarakat, bangsa, dan negara.

Pembangunan pendidikan nasional didasarkan pada paradigma membangun manusia Indonesia seutuhnya, yang berfungsi sebagai subyek yang memiliki kapasitas untuk mengaktualisasikan potensi dan dimensi kemanusiaan secara optimal. Dimensi kemanusiaan mencakup tiga hal paling mendasar, yaitu (1) afektif yang tercermin pada kualitas keimanan, ketakwaan, akhlak mulia termasuk budi pekerti luhur serta kepribadian unggul, dan kompetensi estetis; (2) kognitif yang tercermin pada kapasitas pikir dan daya intelektualitas untuk menggali dan mengembangkan serta menguasai ilmu pengetahuan dan teknologi; dan (3) psikomotorik yang tercermin pada kemampuan mengembangkan keterampilan teknis, kecakapan praktis, dan kompetensi kinestetis. 
Hal ini sesuai dengan tujuan pendidikan nasional dalam UndangUndang Republik Indonesia No. 20 Tahun 2003 tentang sistem Pendidikan Nasional Bab II Pasal 3 yaitu "Pendidikan nasional berfungsi mengembangkan dan membentuk watak serta peradaban bangsa yang bermartabat dalam rangka mencerdaskan kehidupan bangsa, bertujuan untuk berkembangnya potensi peserta didik agar menjadi manusia yang beriman dan bertakwa kepada Tuhan Yang Maha Esa, berakhlak mulia, sehat, berilmu, cakap, kreatif, mandiri, dan menjadi warga negara yang demokratis serta bertanggung jawab".

Dengan demikian, pendidikan seyogyanya menjadi wahana strategis bagi upaya mengembangkan segenap potensi individu, sehingga cita-cita membangun manusia Indonesia seutuhnya dapat tercapai. Atas dasar itu, dapat disimpulkan bahwa pendidikan karakter merupakan inti dari suatu proses pendidikan.

Pendidikan karakter dipahami sebagai upaya menanamkan kecerdasan dalam berpikir, penghayatan dalam bentuk sikap dan pengalaman dalam bentuk perilaku yang sesuai dengan nilai-nilai luhur yang menjadi jati dirinya, diwujudkan dalam interaksi dengan Tuhannya, diri sendiri, antar sesama dan lingkungannya. Oleh karena itu, penanaman pendidikan karakter 
tidak hanya sekadar mentransfer ilmu pengetahuan saja. Penanaman pendidikan karakter perlu proses dan keterlibatan semua pihak, contoh teladan dan pembiasaan dalam lingkungan peserta didik baik di lingkungan sekolah, keluarga, maupun lingkungan masayarakat.

Dari paradigma di atas, dapatlah diambil suatu garis besar bahwasanya pendidikan karakter adalah upaya yang terencana untuk menjadikan peserta didik mengenal, peduli dan menginternalisasi nilai-nilai agar peserta didik mampu menumbuhkan karakter khasnya pada saat menjalankan kehidupan. Dengan kata lain, peserta didik tidak hanya memahami pendidikan sebagai bentuk pengetahuan, namun juga menjadikan sebagai bagian dari hidup dan secara sadar hidup berdasarkan pada nilai tersebut.

\section{Fungsi dan Tujuan Pendidikan Karakter}

1. Fungsi pendidikan karakter Berikut ini fungsi Pendidikan karakter:

a. Pengembangan, pengembangan potensi peserta didik untuk menjadi pribadi berperilaku baik; ini bagi peserta didik yang telah 
memiliki sikap dan perilaku yang mencerminkan budaya dan karakter bangsa;

b. Perbaikan: memperkuat kiprah pendidikan nasional untuk bertanggung jawab dalam pengembangan potensi peserta didik yang lebih bermartabat; dan

c. Penyaring: untuk menyaring budaya bangsa sendiri dan budaya bangsa lain yang tidak sesuai dengan nilai-nilai budaya dan karakter bangsa yang bermartabat (Said Hamid Hasan, 2010).

\section{Tujuan Pendidikan Karakter}

Pendidikan karakter bertujuan untuk meningkatkan mutu dan hasil pendidikan yang mengarah pada pembentukan karakter dan akhlak mulia peserta didik secara utuh, terpadu, dan seimbang, sesuai dengan standar kompetensi lulusan pada setiap satuan pendidikan. Melalui pendidikan karakter peserta didik diharapkan mampu secara mandiri meningkatkan dan menggunakan pengetahuannya, mengkaji dan menginternalisasikan serta mempersonalisasi nilai-nilai karakter dan akhlak mulia sehingga terwujud dalam perilaku sehari-hari. 
Tujuan pendidikan karakter didesain untuk mengembalikan kultur moral peserta didik ke arah yang lebih baik dan berperilaku dalam masyarakat yang lebih manusiawi. Semakin manusiawi maka mampu berelasi secara sehat di lingkungan dan menjadi manusia yang bertanggung jawab. Dengan ditempatkannya pendidikan karakter sebagai pembentuk pedoman perilaku, pengayaan nilai-nilai peserta didik dan dengan memberikan keteladanan bagi peserta didik, maka peserta didik dapat pengembangan dalam dirinya baik intelektual, sosial, moral, maupun religius. Dengan ditanamkannya pendidikan karakter pada lembaga pendidikan diharapkan mampu membuat suatu perubahan tata kehidupan peserta didik dengan lingkungan. Undang-undang Dasar Negara Republik Indonesia Tahun 1945 mengamanatkan agar pemerintah mengusahakan dan menyelenggarakan suatu sistem pendidikan nasional yang meningkatkan keimanan dan ketakwaan kepada Tuhan Yang Maha Esa serta akhlak mulia dalam rangka mencerdaskan kehidupan bangsa. Secara jelas, tujuan pendidikan karakter adalah:

Pertama, pendidikan karakter adalah memfasilitasi penguatan dan pengembangan nilai-nilai tertentu sehingga terwujud dalam perilaku anak, baik ketika proses sekolah maupun 
setelah proses sekolah atau di lingkungan masyarakat. Penguatan dan pengembangan memiliki makna bahwa pendidikan dalam seting sekolah bukanlah proses yang membawa peserta didik untuk memahami dan mereflesi bagaimana suatu nilai menjadi penting untuk diwujudkan dalam perilaku keseharian peserta didik. Penguatan juga mengarahkan proses pendidikan pada proses pembiasaan yang disertadi oleh logika dan refleksi terhadap proses dan dampak dari proses pembiasaan yang dilakukan oleh sekolah baik dalam seting kelas maupun sekolah.

Kedua, pendidikan karakter adalah mengkoreksi perilaku peserta didik yang tidak sesuai dengan nilai - nilai yang dikembangkan oleh sekolah. Tujuan ini memiliki makna bahwa pendidikan karakter memiliki sasaran untuk meluruskan perilaku peserta didik yang negatif menjadi positif. Kemudian tujuan yang ketiga dalam pendidikan karakter seting sekolah adalah membangun koneksi yang harmoni dengan keluarga dan masyarakat dalam memerankan tanggung jawab pendidikan karakter secara bersama. Pendidikan karakter ini memiliki makna bahwa proses pendidikan karakter di sekolah harus dihubungkan dengan proses pendidikan di keluarga. Jika saja penerapan pendidikan karakter tidak hanya interaksi sesama peserta didik 
dan guru maka pencapaian pendidikan karakter akan sulit terwujud.

Tujuan lain dari pendidikan karakter yang dikemukakan oleh Kemendiknas dalam buku pengembangan budaya dan karakter bangsa adalah:

a. Mengembangkan potensi kalbu/nurani/afektif peserta didik sebagai manusia dan warga negaranya yang memiliki nilai-nilai budaya dan karakter bangsa.

b. Mengembangkan kebiasaan dan perilaku peserta duidik yang terpuji dan sejalan dengan nilai-nilai universal dan tradisi budaya yang religius.

c. Menanamkan jiwa kepemimpinan dan tanggung jawab peserta didik sebagai generasi penerus bangsa.

d. Mengembangkan kemampuan peserta didik menjadi manusia yang mandiri, kreatif, berwawasan kebangsaan.

e. Mengembangkan lingkungan kehidupan sebagai lingkungan belajar yang aman, jujur, penuh kreatifitas, dan persahabatan, serta dengan rasa kebangsaan yang tinggi dan penuh kekuatan.

\section{Strategi Pelaksanaan Pendidikan Karakter}

Strategi Pendidikan Karakter yang akan dibahas adalah Strategi Pendidikan Karakter melalui Multiple Talent Aproach 
(Multiple Intelligent).Strategi Pendidikan Karakter ini memiliki tujuan yaitu untuk mengembangkan seluruh potensi anak didik yang manifestasi pengembangan potensi akan membangun Self Concept yang menunjang kesehatan mental. Konsep ini menyediakan kesempatan bagi anak didik untuk mengembangkan bakat emasnya sesuai dengan kebutuhan dan minat yang dimilikinya. Ada banyak cara untuk menjadi cerdas, dan cara ini biasanya ditandai dengan prestasi akademik yang diperoleh di sekolahnya dan anak didik tersebut mengikuti tes intelengensia. Cara tersebut misalnya melalui kata-kata, angka, musik, gambar, kegiatan fisik atau kemampuan motorik atau lewat cara sosial emosional. Menurut Gardner (1999), manusia itu sedikitnya memiliki 9 kecerdasan. Kecerdasan manusia, saat ini tak hanya dapat diukur dari kepandaiannya menguasai matematika atau menggunakan bahasa. Ada banyak kecerdasan lain yang dapat diidentifikasi di dalam diri manusia. Sedangkan menurut Howard Gardner (1999) yang menjelaskan 9 kecerdasan ganda, apabila dipahami dengan baik, akan membuat semua orang tua memandang potensi anak lebih positif. Terlebih lagi, para orang tua (guru) dapat menyiapkan sebuah lingkungan yang menyenangkan dan memperdayakan di sekolah. Konsep Multiple Intelligence mengajarkan kepada anak bahwa mereka bisa belajar 
apapun yang mereka ingin ketahui. Bagi Orang tua atau guru, yang dibutuhkan adalah kreativitas dan kepekaan untuk mengasah anak tersebut. Baik guru atau orang tua juga harus berpikir terbuka, keluar dari paradigma tradisional. Kecerdasan bukanlah sesuatu yang bersifat tetap. Keceradasan bagaikan sekumpulan keterampilan yang dapat ditumbuhkan dan dikembangkan.

Kecerdasan adalah kemampuan untuk memecahkan masalah, kemampuan untuk menciptakan masalah baru untuk dipecahkan, kemampuan untuk menciptakan sesuatu yang berharga dalam suatu kebudayaan masyarakat. Melalui pengenalan Multiple Intellegence akan dapat mempelajari kekuatan atau kelemahan anak dan dapat memberikan mereka peluang untuk belajar melalui kelebihan mereka, tujuannya adalah agar anak memiliki kesempatan untuk mengeksplorasi dunia (Omeri, 2015)

a. Pada hakikatnya, tujuan pendidikan nasional tidak boleh melupakan landasan konseptual filosofi pendidikan yang mampu menyiapkan generasi masa depan untuk dapat bertahan hidup (survive) dan berhasil menghadapi tantangan-tantangan zamannya. Fungsi dan tujuan pendidikan nasional menurut Undang-Undang Sistem Pendidikan Nasional Tahun 2003 Bab 2 
Pasal 3 adalah sebagai berikut."Pendidikan nasional berfungsi mengembangkan kemampuan dan membentuk watak serta peradaban bangsa yang bermartabat dalam rangka mencerdaskan kehidupan bangsa, bertujuan untuk berkembangnya potensi peserta didik agar menjadi manusia yang beriman dan bertakwa kepada Tuhan Yang Maha Esa, berakhlak mulia, sehat, berilmu, cakap, kreatif, mandiri, dan menjadi warga negara yang demokratis serta bertanggung jawab (Undang-Undang No. 20 Tahun 2003).

Mencermati fungsi pendidikan nasional, yakni mengembangkan kemampuan dan membentuk watak serta peradaban bangsa seharusnya memberikan pencerahan yang memadai bahwa pendidikan harus berdampak pada watak manusia atau bangsa Indonesia. Fungsi ini amat berat untuk dipikul oleh pendidikan nasional, terutama apabila dikaitkan dengan siapa yang bertanggung jawab untuk keberlangsungan fungsi ini.

b. Fungsi pertama "mengembangkan kemampuan" dapat dipahami bahwa pendidikan nasional menganut aliran konstruktivisme, yang mempercayai bahwa peserta didik adalah manusia yang potensial dan dapat dikembangkan secara optimal melalui proses pendidikan. Setiap layanan pendidikan yang ada 
di Indonesia harus dipersepsi secara sama bahwa peserta didik itu memiliki potensi yang luar biasa dan perlu difasilitasi melalui proses pendidikan untuk mengembangkan potensinya. Dalam konteks pendidikan karakter, dapat dilihat bahwa kemampuan yang harus dikembangkan pada peserta didik melalui persekolahan adalah berbagai kemampuan yang akan menjadikan manusia sebagai makhluk yang berketuhanan dan mengemban amanah sebagai pemimpin di dunia. Kemampuan yang perlu dikembangkan pada peserta didik adalah kemampuan mengabdi kepada Tuhan yang menciptakannya, kemampuan untuk menjadi dirinya sendiri, kemampuan untuk hidup secara harmonis dengan manusia dan makhluk lainnya, dan kemampuan untuk menjadikan dunia ini sebagai wahana kemakmuran dan kesejahteraan bersama.

c. Fungsi kedua pendidikan nasional adalah "membentuk watak" mengandung makna bahwa pendidikan nasional harus diarahkan pada pembentukan watak. Pendidikan yang berorientasi pada watak peserta didik merupakan suatu hal yang tepat, tetapi perlu diperjelas mengenai istilah perlakuan terhadap "watak." Apakah watak itu harus "dikembangkan", "dibentuk" atau "difasilitasi." Perspektif pedagogik, lebih memandang bahwa pendidikan itu mengembangkan/ menguatkan/ 
memfasilitasi watak, bukan membentuk watak. Jika watak dibentuk, maka tidak ada proses pedagogik/ pendidikan, yang terjadi adalah pengajaran (Dharma Kesuma, dkk., 2011: 7).

d. Ukuran keberhasilan pendidikan yang berhenti pada angka ujian, seperti halnya ujian nasional, adalah sebuah kemunduran, karena dengan demikian pembelajaran akan menjadi sebuah proses menguasai keterampilan dan mengakumulasi pengetahuan. Paradigma ini menempatkan peserta didik sebagai pelajar imitatif dan belajar dari ekspose-ekspose didaktik yang akan berhenti pada penguasaan fakta, prinsip, dan aplikasinya. Paradigma ini tidak sesuai dengan esensi pendidikan yang digariskan dalam Undang-Undang Sistem Pendidikan Nasional.

e. Apa tujuan pendidikan karakter dalam seting sekolah? Pendidikan karakter dalam seting sekolah memiliki tujuan sebagai berikut,

1. Menguatkan dan mengembangkan nilai-nilai kehidupan yang dianggap penting dan perlu sehingga menjadi kepribadian/ kepemilikan peserta didik yang khas sebagaimana nilai-nilai yang dikembangkan. Penguatan dan pengembangan memiliki makna bahwa pendidikan dalam seting sekolah bukanlah sekedar dogmatisasi nilai kepada peserta didik, tetapi sebuah proses yang membawa peserta didik untuk memahami dan merefleksi 
bagaimana suatu nilai menjadi penting untuk diwujudkan dalam perilaku keseharian.

2. Mengoreksi perilaku peserta didik yang tidak bersesuaian dengan nilai-nilai yang dikembangkan oleh sekolah.Tujuan ini memiliki makna bahwa pendidikan karakter memiliki sasaran untuk meluruskan berbagai perilaku anak yang negatif menjadi positif. Proses pelurusan yang dimaknai sebagai pengkoreksian perilaku dipahami sebagai proses yang pedagogis, bukan suatu pemaksaan atau pengkondisian yang tidak mendidik.

3. Membangun koneksi yang harmonis dengan keluarga dan masyarakat dalam memerankan tanggung jawab pendidikan karakter secara bersama-sama. Tujuan ini memiliki makna bahwa proses pendidikan karakter di sekolah harus dihubungkan dengan proses pendidikan di keluarga. Jika pendidikan karakter di sekolah hanya bertumpu pada interaksi antara peserta didik dengan guru di kelas dan sekolah, maka pencapaian berbagai karakter yang diharapkan sulit diwujudkan (Warsito, 2018)

\section{E. Ruang Lingkup dan Komponen-Komponen Pendidikan Karakter}

Pendidikan karakter meliputi 2 aspek yang dimiliki manusia, yaitu aspek ke dalam dan aspek keluar. Aspek ke dalam atau 
potensia meliputi aspek kognitif (olah pikir), aspek afektif (olah batin) dan aspek psikomotor (olah raga). Aspek luar adalah proses pendidikan dan lingkungan, seperti budaya sekolah dan kegiatan sekolah. Masing-masing aspek memiliki ruang yang berisi nilainilai pendidikan karakter

Menurut Kemendiknas ruang lingkup pendidikan karakter digambarkan sebagai berikut:

1. Olah batin meliputi sikap-sikap; beriman dan bertaqwa, jujur, amanah, adil, bertanggungjawab, berempati, berani mengambil resiko, pantang menyerah, rela berkorban, dan berjiwa patriotik.

2. Olah rasa/karsa meliputi sikap-sikap; ramah, saling menghargai, toleran, peduli, suka menolong, gotong royong, nasionalis, mengutamakan kepentingan umum, bangga menggunakan bahasa dan produk Indonesia,dinamis, kerja keras dan beretos kerja.

3. Olah pikir meliputi sikap-sikap; cerdas, kreatif, inovatif, ingin tahu, berfikir terbuka, produktif, berorientasi iptek.

4. Olah raga meliputi sikap-sikap; bersih dan sehat, disiplin dan sportif, tangguh,andal, kooperatif, kompetetif, ceria dan gigih. Lebih jelasnya digambarkan pada gambar: 


\section{Olah Pikir \\ Olah Batin}

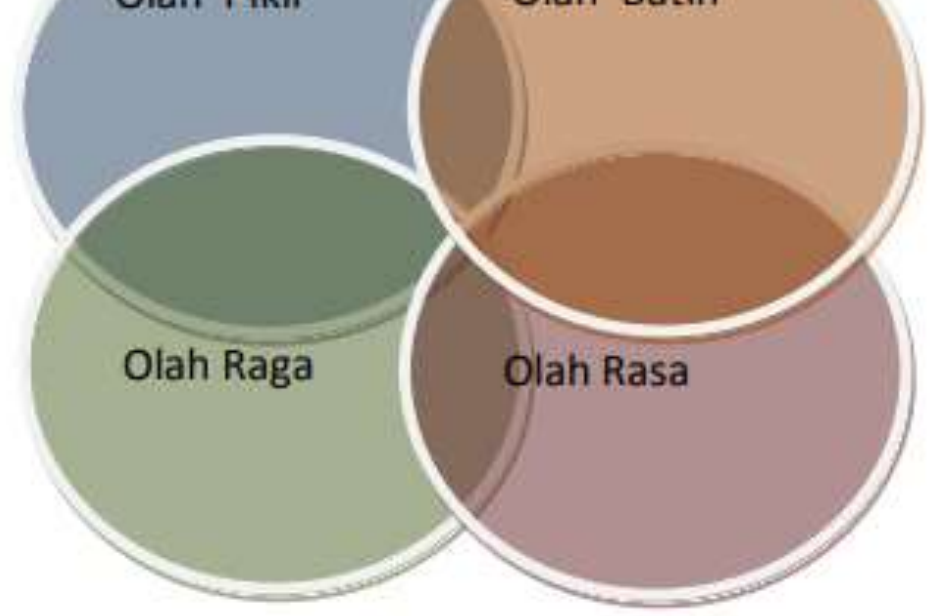

Gambar : 2.1 Koherensi nilai nilai karakter

Selain ruang lingkup pendidikan karakter sebagaimana diuraikan di atas, terdapat komponen-komponen utama pendidikan karakter antara lain:

a. Moral knowing yang meliputi, kesadaran moral, memahami nilainilai moral, mengambil perspektif alasan moral, pengambilan keputusan dan pengendalian diri.

b. Moral feeling yang meliputi hati nurani, harga diri, empaty, mencintai kebaikan, control diri dan kerendahan hati.

c. Moral action yang meliputi, kompetensi dan kemauan serta habit. 


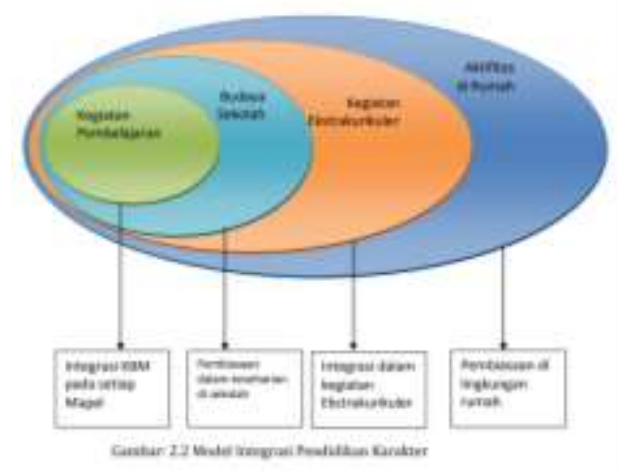

BAB II

\section{PELAKSANAAN PENDIDIKAN KARAKTER}

\section{A. Pendididikan Karakter di Sekolah}

Pelaksanaan Pendidikan karakter di sekolah yang dikemukakan oleh para ahli pendidikan karakter dikemukakan berbagai cara atau metode: Pertama, menggunakan metode pemahaman. Socrates dalam Ratna Megawangi mengemukakan perlunya formula $4 \mathrm{M}$ dalam pendidikan karakter, yaitu: Mengetahui (knowing the good), mencintai ( loving the good), menginginkan (desiring the good), dan mengerjakan (acting the good) kebaikan secara simultan dan berkesinambungan. Cara ini menunjukkan bahwa karakter adalah sesuatu yang dikerjakan berdasarkan kesadaran yang utuh. Sedangkan kesadaran utuh itu 
adalah sesuatu yang diketahui secara sadar, dicintainya, dan diinginkan. Dari kesadaran utuh ini, barulah tindakan dapat menghasilkan karakter yang utuh pula. Proses pengajaran yang bermula dari memberikan pengetahuan peserta didik tentang kebaikan, menggiring atau mengkondisikan agar peserta didik mencintai kebaikan tersebut, kemudian membangkitkan peserta didik agar menginginkan karakter yang diajarkan, dan terakhir mengondisikan peserta ddidik agar mengerjakan kebaikan secara sukarela, simultan dan berkesinambungan.

Kedua, metode atau dengan cara pembiasaan. Pembiasaan merupakan alat penddidikan. Dalam pembiasaan peserta didik dipancing untuk menyadari karakter tertentu yang telah ditentukan, baru kemudian karakter yang telah disadari dan diinginkan itu dibiasakan dalam keseharian. Pembiasaan dimulai dengan menetapkan sikap atau tingkah laku atau karakter yang baik kemudian dilatihkan dan dibiasakan kepada peserta didik. Secara berproses, latihan-latihan yang dilakukan apabila diikuti dengan kesadaran dan mawas diri, lama kelamaan akan menyatu dalam kepribadian peserta didik dan itu menjadi karakter. Kebiasaan tersebut harus dilestarikan sehingga mempribadi atau menyatu dalam kehidupan peserta didik. 
Kemudian dalam pelaksanaan pendidikan karakter di sekolah Doni A. Koesoema dalam Bambang Q-Anees (2008), mengajukan lima metode atau lima cara pendidikan karakter yaitu

\section{Mengajarkan}

Mengajarkan karakter berarti memberikan pemahaman pada peserta didik tentang struktur nilai tertentu, keutamaan (bila dilaksanakan), maslahatnya, manfaatnya, kegunaannya, kerugiannya atau bahayanya (bila tak dilaksanakan). Mengajarkan nilai-nilai memiliki dua faedah. Pertama, memberikan pengetahuan konseptual baru. Kedua, menjadi pembanding atas pengetahuan yang telah dimiliki oleh peserta didik, karena proses mengajarkan tidaklah menolong, melainkan melibatkan peserta didik. Inilah unsur metode pendidikannya.

Dalam konsep mengajarkan ini yaitu memberikan kesempatan kepada peserta didik untuk mengajukan apa yang difahaminya, apa yang pernah dialaminya, dan bagaimana perasaannya berkenaan dengan konsep yang diajarkan. Melalui cara ini, konsep yang diajarkan bukanlah sesuatu yang asing dan 
baru melainkan sudah dialami atau pernah teramati oleh peserta didik. Konsep tetap diberikan dan menjadi otoritas guru. Konsep yang diberikan guru dapat bermanfaat bagi peserta didik bukan sebagai doktrin melainkan sebagai norma-norma bagi apa yang telah dialami peserta didik. Dalam mengajarkan konsep-konsep ini disertai dengan contoh-contoh yang pernah dan teramati oleh peserta didik.

\section{Keteladanan}

Keteladanan adalah alat utama dalam pendidikan . Hal ini dipraktekan oleh Rasulullah Muhammad saw. dalam mendidik umatnya. Firman Allah menyatakan "Laqad kana lakum fi rasulillahi uswatun hasanah" artinya "Sungguh telah ada pada diri Rasulullah contoh tauladan yang baik" (Q.S.Al Ahzab: 21). Dalam pendidikan karakter, keteladanan perlu dikembangkan oleh orang tua di lingkungan keluarga, guru-guru di sekolah, tokoh masyarakat dan ulama serta para pemimpin bangsa. Peribahasa mengatakan "Bahasa tingkah laku (keteladanan) lebih mantap ketimbang bahasa ucapan. Dakwah bil hal lebih baik dengan dakwah bil qaul. Guru harus terlebih dahulu memilki karakter yang hendak diajarkan, guru adalah yang digugu dan 
ditiru (digugu ucapannya dan ditiru perilakunya). Peserta didik akan meniru apa yang dilakukan gurunya.

Keteladanan tidak hanya bersumber dari guru di sekolah, tapi dari seluruh tenaga keependidikan lainnya yang ada di lembaga sekolah mulai dari kepala Sekolah, staf tata usaha, administrasi, pustakawan, dimana peserta didik berada dan sering berhubungan. Oleh sebab itu pendidikan karakter membutuhkan lingkungan pendidikan yang utuh.

\section{Menentukan Prioritas}

Penentuan prioritas harus ditentukan agar proses evaluasi atas berhasil tidaknya pendidikan karakter dapat menjadi jelas. Tanpa prioritas, pendidikan karakter tidak dapat terfokus dan karenanya tidak daapat dinilai berhasil atau tidak berhasil. Lembaga sekolah memilki beberapa kewajiban: Pertama, menentukan tuntutan standar yang akan ditawarkan pada peserta didik. Kedua, semua pribadi yang terlibat dalam lembaga pendidikan harus memahami secara jernih apa nilai yang ingin ditekankan dalam lembaga pendidikan karakter. Ketiga, jika lembaga ingin menetapkan perilaku struktur yang menjadi ciri khas lembaga, maka karakter standar itu harus difahami oleh anak didik. 
4. Praksis Prioritas

Lembaga pendidikan harus mampu membuat verifikasi sejauh mana prioritas yang telah ditentukan telah dapat direalisasikan dalam lingkup pendidikan melalui berbagai unsur yang ada dalam lembaga pendidikan ini.

5. Refleksi

Refleksi disini berarti dipantulkan kedalam diri. Apa yang telah dialami masih tetap terpisah dengan kesadaran diri sejauh ia belum dikaitkan, dipantulkan dengan isi kesadaran seseorang. Refleksi disini merenungkan apa-apa yang telah dipelajarinya. Refleksi disini dapat juga disebut sebagai proses bercermin, mematut-matutkan diri pada peristiwa/konsep yang telah dialami, apakah saya seperti itu? Apakah ada karakter baik seperti itu pada diri saya?

Selain metode-metode tersebut di atas, dalam pendidikan karakter di sekolah ada lagi sebagai alternatif metode dialog partisipatif, dan metode eksperimen. Metode dialog partisipatif mendorong para siswa untuk kreatif, kritis, mandiri, dan terampil berkomunikasi.

Metode dialog partisipasi dijabarkan/dikonkritkan dalam kegiatan-kegiatan seperti diskusi kelompok, sharing pengalaman keseharian dan sharing pengalaman iman, wawancaara, dramatisasi, dinamika kelompok 
dan sebagainya. Metode naratif menggunakan cerita sebagai model pengembangan diri. Metode ini dianggap unggul karena bersifat merangsang imajinasi peserta didik, menyapa peserta didik secara menyeluruh, baik segi kognitif maupun afektif, bersifat menawarkan, membebaskan dan tidak menjejali.

\section{a. Peran Sekolah}

Jika dilingkungan rumah/keluarga, anak dapat dikatakan "menerima apa adanya" dalam menerapkan sesuatu perbuatan, maka dilingkungan sekolah sesuatu hal menjadi “mutlak"adanya, sehingga sering didengar anak mengatakan pada orang tuanya "Ma, Pa, kata Bu guru/ Pak guru begini bukan begitu”. Ini menunjukkan bahwa pengaruh sekolah sangat besar dalam membentuk pola pikir dan karakter anak. Namun hal ini pun bukanlah sesuatu yang mudah tercapai tanpa ada usaha yang dilakukan. Untuk menjadi 'Bapak dan Ibu' guru seperti dalam ilustrasi di atas butuh keteladanan dan konsistensi perilaku yang patut diteladani. Contoh-contoh perilaku yang dapat diterapkan di sekolah:

1) Membiasakan siswa berbudaya salam, sapa dan senyum

2) Tiba di sekolah mengucap salam sambil salaman dan cium tangan guru. 
3) Menyapa teman, satpam, penjual dikantin atau cleaning servis di sekolah

4) Menyapa dengan sopan tamu yang datang ke sekolah

5) Membiasakan siswa berbicara dengan bahasa yang baik dan santun

6) Mendidik siswa duduk dengan sopan di kelas

7) Mendidik siswa makan sambil duduk di tempat yang telah disediakan, tidak sambil jalan- jalan Membimbing dan membiasakan

8) Siswa shalat Dhuha dan shalat Dzuhur berjamaah di sekolah

Sekolah, pada hakikatnya bukanlah sekedar tempat "transfer of knowledge" belaka. Seperti dikemukakan Fraenkel (1977: 1-2), sekolah tidaklah semata-mata tempat guru menyampaikan pengetahuan melalui berbagai mata pelajaran. Sekolah juga adalah lembaga yang mengusahakan usaha dan proses pembelajaran yang berorientasi pada nilai (value-oriented enterprise).

Pembentukan karakter merupakan bagian dari pendidikan nilai (values education) melalui sekolah, merupakan usaha mulia yang mendesak untuk dilakukan. Bahkan, kalau berbicara tentang 
masa depan, sekolah bertanggungjawab bukan hanya dalam mencetak peserta didik yang unggul dalam ilmu pengetahuan dan teknologi, tetapi juga dalam jati diri, karakter dan kepribadian.

Usaha pembentukan watak melalui sekolah, secara berbarengan dapat pula dilakukan melalui pendidikan nilai dengan langkah-langkah sebagai berikut: Pertama, menerapkan pendekatan "modelling" atau "exemplary" atau "uswah hasanah". Yakni mensosialisasikan dan membiasakan lingkungan sekolah untuk menghidupkan dan menegakkan nilai-nilai akhlak dan moral yang benar melalui model atau teladan. Setiap guru dan tenaga kependidikan lain di lingkungan sekolah hendaklah mampu menjadi "uswah hasanah" yang hidup (living exemplary) bagi setiap peserta didik. Mereka juga harus terbuka dan siap untuk mendiskusikan dengan peserta didik tentang berbagai nilainilai yang baik tersebut.

Kedua, menjelaskan atau mengklarifikasikan kepada peserta didik secara terus menerus tentang berbagai nilai yang baik dan yang buruk. Usaha ini bisa dibarengi pula dengan langkah-langkah; memberi penghargaan (prizing) dan menumbuhsuburkan (cherising) nilai-nilai yang baik dan sebaliknya mengecam dan mencegah (discouraging) berlakunya nilai-nilai yang buruk; menegaskan nilai nilai yang baik dan 
buruk secara terbuka dan kontinu; memberikan kesempatan kepada peserta didik untuk memilih berbagai alternatif sikap dan tindakan berdasarkan nilai; melakukan pilihan secara bebas setelah menimbang dalam-dalam berbagai konsekuensi dari setiap pilihan dan tindakan; membiasakan bersikap dan bertindak atas niat dan prasangka baik (husn al-zhan) dan tujuan-tujuan ideal; membiasakan bersikap dan bertindak dengan pola-pola yang baik yang diulangi secara terus menerus dan konsisten.

Ketiga, menerapkan pendidikan berdasarkan karakter (character-based education). Hal ini bisa dilakukan dengan menerapkan character-based approach ke dalam setiap mata pelajaran nilai yang ada di samping mata pelajaran-mata pelajaran khusus untuk pendidikan karakter, seperti pelajaran agama, pendidikan kewarganegaraan (PKn), sejarah, Pancasila dan sebagainya.

Pembentukan watak dan pendidikan karakter melalui sekolah, dengan demikian, tidak bisa dilakukan semata-mata melalui pembelajaran pengetahuan, tetapi adalah melalui penanaman atau pendidikan nilai-nilai. Apakah nilai-nilai tersebut? Secara umum, kajian-kajian tentang nilai biasanya mencakup dua bidang pokok, estetika, dan etika (atau akhlak, moral, budi pekerti). Estetika mengacu kepada hal-hal tentang 
dan justifikasi terhadap apa yang dipandang manusia sebagai "indah", apa yang mereka senangi. Sedangkan etika mengacu kepada hal-hal tentang dan justifikasi terhadap tingkah laku yang pantas berdasarkan standar-standar yang berlaku dalam masyarakat, baik yang bersumber dari agama, adat istiadat, konvensi, dan sebagainya. Dan standar-standar itu adalah nilainilai moral atau akhlak tentang tindakan mana yang baik dan mana yang buruk.

Sekolah merupakan sarana yang secara sengaja dirancang untuk melaksanakan pendidikan. Karena kemajuan zaman, maka keluarga tidak mungkin lagi memenuhi seluruh kebutuhan dan aspirasi anak terhadap iptek. Semakin maju suatu masyarakat, semakin penting peranan sekolah dalam mempersiapkan generasi muda sebelum masuk dalam proses pembangunan masyarakat itu. Suatu alternatif yang mungkin dilakukan untuk meningkatkan sekolah dalam perannya sebagai lembaga pendidikan sesuai dengan situasi dan kondisi sekolah, antara lain:

a) Pengajaran yang mendidik

Yaitu pengajaran yang serentak memberi peluang pencapaian tujuan intruksional bidang studi dan tujuan-tujuan umum pendidikan lainnya. Dalam upaya mewujudkan pengajaran 
yang mendidik, perlu dikemukakan bahwa setiap keputusan dan tindakan guru dalam rangka kegiatan belajar mengajar akan membawa berbagai dampak atau efek kepada siswa, Pemilihan kegiatan belajar yang etpat, akan memberikan pengalaman belajar siswa yang efisien dan efektif untuk mewujudkan pembangunan manusia seutuhya. Hal ini dapat dilaksanakan dengan konsisten apabila guru memiliki wawasan kependidikan yang tepat serta menguasai berbagai strategi belajar mengajar sehingga mampu dan mau merancang dan melaksanakan berbagai kegiatan belajar mengajar yang kaya dan bermakna bagi peserta didik. Selain itu, pemberian prakarsa dan tanggung jawab sedini mungkin kepada anak dalam kegiatan belajar mengajar akan memupuk kebiasaan dan kemampuan belajar mandiri yang terus menerus. Dengan demikian diharapkan peran sekolah dapat mewujudkan suatu masyarakat yang cerdas. 
b). Peningkatan dan Pemantapan Program Bimbingan dan Konseling (BK) di Sekolah

Seperti diketahui, bidang garapan program Bimbingan Konseling (BK) adalah perkembangan pribadi peserta didik, khususnya aspek sikap dan perilaku atau kawasan afektif. Dalam pedoman kurikulum disebutkan bahwa pelaksanaan kegiatan BK di sekolah menitikberatkan kepada bimbingan terhadap perkembangan pribadi melalui pendekatan perseorangan dan kelompok. Siswa yang menghadapi masalah mendapat bantuan khusus agar mampu mengatasi masalahnya. Semua siswa tetap mendapatkan bimbingan karier. Pendidikan afektif dapat diawali dengan kajian tentang nilai dan sikap yang seharusnya dikejar lebih jauh dalam perwujudannya melalui perilaku sehari-hari.

c). Pengembangan Perpustakaan Sekolah

Perpustakaan sekolah merupakan salah satu pusat sumber belajar, yang mengelola bukan hanya bahan pustaka tetapi juga berbagai sumber belajar lainnya. Perpustakan diharapkan peranannya bisa lebih aktif dalam mendukung program pendidikan. Dengan penyediaan berbagai perangkat lunak yang didukung perangkat keras yang memadai maka perpustakaan 
dapat menjadi "mitra kelas" dalam proses belajar mengajar dan tempat pengkajian berbagai pengembangan sistem instruksional. Suatu perpustakaan sekolah yang memadai akan dapat mendorong siswa atau anak untuk belajar mandiri.

d). Peningkatan Program Pengelolaan Sekolah

Khususnya yang terkait dengan peserta didik, pengelola sekolah sebagai pusat pendidikan dan kebudayaan seharusnya merupakan refleksi dari suatu masyarakat yang beradab yang dicita-citakan oleh tujuan nasional. Gaya kerja pengelola umumnya, akan berpengaruh bukan hanya melalui kebijakannya tetapi juga aspek keteladanannya.

Selain diperlukan sosok guru ideal yang mampu membuat ramuan perencanaan pembelajaran berbasis pendidikan karakter, dukungan iklim dan budaya sekolah/Sekolah/Madrasah pun akan sangat menentukan hasil dari proses internalisasi. Demikian halnya dengan ketersediaan sarana dan prasarana yang mendukung. Peran kepemimpinan dari seorang Kepala Sekolah/Sekolah/Madrasah akan sangat menentukan hal tersebut dapat terwujud. Disamping peran serta yang optimal dari seluruh perangkat sekolah/Sekolah/Madrasah. 
Selain melalui upaya di atas, apa yang diungkapkan oleh Bagir, dkk (2005: 108) dapat menjadi referensi para praktisi pendidikan di lingkungan persekolahan dalam mengembangkan strategi pendidikan karakter di lingkungan Sekolah/Madrasah. Menurutnya bahwa terdapat empat tataran implementasi, yaitu tataran konseptual, institusional, operasional, dan arsitektural.

Dalam tataran konseptual, internalisasi pendidikan karakter dapat diwujudkan melalui perumusan visi, misi, tujuan dan program Sekolah/Madrasah (rencana strategis Sekolah/Madrasah), adapun secara institusional, integrasi dapat diwujudkan melalui pembentukan institution culture yang mencerminkan adanya misi pendidikan karakter, sedangkan dalam tataran operasional, rancangan kurikulum dan esktrakulikuler (Kurikulum Tingkat Satuan Pendidikan/KTSP) harus diramu sedemikian rupa sehingga nilai-nilai fundamental agama prihal akhlak mulia dan kajian ilmu/ilmiah prihal akhlak mulia terpadu secara koheren. Sementara secara arsitektural, internalisasi dapat diwujudkan melalui pembentukan lingkungan fisik yang berbasis pendidikan akhlak, seperti sarana ibadah yang lengkap, sarana laboratorium yang memadai, serta perpustakaan yang menyediakan buku-buku prihal akhlak mulia. 
Adapun Sulhan (2010: 15-16) mengemukakan tentang beberapa langkah yang dapat dikembangkan oleh Sekolah/Madrasah dalam melakukan proses pembentukan karakter pada siswa. Adapun langkah tersebut adalah sebagai berikut:

1) Memasukan konsep karakter pada setiap kegiatan pembelajaran dengan cara:

a) Menambahkan nilai kebaikan kepada anak (knowing the good)

b) Menggunakan cara yang dapat membuat anak memiliki alasan atau keinginan untuk berbuat baik (desiring the good)

c) Mengembangkan sikap mencintai untuk berbuat baik (loving the good)

2) Membuat slogan yang mampu menumbuhkan kebiasaan baik dalam segala tingkah laku masyarakat sekolah

3) Pemantauan secara kontinyu. Pemantauan secara kontinyu merupakan wujud dari pelaksanaan pembangunan karakter. Beberapa hal yang harus selalu dipantau diantaranya adalah:
a) Kedisiplinan masuk pesantren
b) Kebiasaan saat makan di kantin
c) Kebiasaan dalam berbicara
d) Kebiasaan ketika di masjid, dll 
4) Penilaian orangtua. Rumah merupakan tempat pertama sebenarnya yang dihadapi anak. Rumah merupakan tempat pertama anak berkomunikasi dan bersosialisasi dengan lingkungannya. Untuk itulah, orangtua diberikan kesempatan untuk menilai anak, khususnya dalam pembentukan moral anak.

Selain pendekatan-pendekatan di atas, minimal terdapat empat strategi yang bisa menjadi alternatif pendidikan karakter di Sekolah:

1) Pendekatan Normatif, yakni mereka (perangkat Sekolah/Madrasah) secara bersama-sama membuat tata kelola (good governence) atau tata tertib penyelenggaraan Sekolah/Madrasah yang di dalamnya dilandasi oleh nilai-nilai pendidikan karakter/akhlak, perumusan tata kelola ini penting dibuat secara bersama, bahkan melibatkan santri dan tidak bersifat top down dari pimpinan Sekolah/Madrasah Sehingga terlahir tanggung jawab moral kolektif yang dapat melahirkan sistem kontrol sosial, yang pada giliranya mendorong terwujudnya institution culture yang penuh makna.

2) Pendekatan Model yakni mereka (perangkat Sekolah/Madrasah), khususnya pimpinan Sekolah/Madrasah berupaya untuk menjadi model dari tata tertib yang dirumuskan, ucap, sikap dan 
prilakunya menjadi perwujudan dari tata tertib yang disepakati bersama.

3) Pendekatan Reward and Punishment yakni diberlakukanya sistem hadiah dan hukuman sebagai stimulus dan motivator terwujudnya tata kelola yang dibuat.

4) Pendekatan Suasana Belajar (baik suasana fisik maupun suasana psikis) yakni dengan mengkondisikan suasana belajar agar menjadi sumber inspirasi penyadaran nilai bagi seluruh perangkat Sekolah/Madrasah, termasuk para siswa seperti dengan memasang visi Sekolah/Madrasah, kata-kata hikmah, ayat-ayat Al Qur'an dan mutiara Hadits di tempat-tempat yang selalu terlihat oleh siapapun yang ada di Sekolah/Madrasah, memposisikan bangunan masjid di arena utama Sekolah/Madrasah, memasang kaligrafi di setiap ruangan belajar, membiasakan membaca Al Qur'an setiap mengawali belajar dengan dipimpin guru, program shalat berjamaah, kuliah tujuh menit, perlombaan-perlombaan dan sebagainya. (Subianto, 2013)

Sistem pendidikan dan lingkungan sekolah yang mengayomi dapat memacu keinginan dalam setiap anak untuk mengembangkan rasa bangga pada diri mereka untuk selalu berusaha mencapai kemampuan terbaik mereka sebagai seorang 
yang seimbang dan berkembang secara utuh untuk mengembangkan kualitas dan keterampilan yang diperlukan sebagai pembelajar sejati dan sebagi bagian dari masyarakat global. Demikianlah beberapa alternatif yang dapat dilakukan untuk meningkatkan fungsi sekolah sebagai salah satu pusat pendidikan.

\section{b. Pelaksanaan Pendidikan Karakter di Sekolah}

Rusyan (2014: 251-252) menyebutkan bahwa sekolah sebagai pusat pendidikan, sebagai lembaga pendidikan, dan merupakan lingkungan pendidikan. Tugas dan fungsi sekolah adalah untuk menyelenggarakan pembelajaran yang pelaksanaannya perlu terencana, tertib, dan teratur agar usaha untuk menyediakan diri terampil dan hasilnya benar-benar memuaskan.

Dengan demikian, lingkungan sekolah dapat menjadi tempat yang baik dalam menanamkan karakter siswa. Segala kegiatan yang ada di sekolah, baik kegiatan pembelajaran maupun kegiatan pembiasaan-pembiasaan yang ada di sekolah semestinya dapat diintegrasikan dalam program pendidikan karakter. 
Berdasarkan fungsi dan tujuan pendidikan nasional UU No. 20 Tahun 2003 Pasal 3, Masnur (2018: 84) menerangkan bahwa pendidikan karakter di sekolah adalah suatu sistem penanaman nilai-nilai karakter kepada warga sekolah yang meliputi komponen pengetahuan, kesadaran atau kemauan, dan tindakan untuk melaksanakan nilai-nilai tersebut, baik terhadap Tuhan Yang Maha Esa, diri sendiri, sesama, lingkungan, maupun kebangsaan, sehingga menjadi manusia insan kamil. Masnur (2018: 87) juga menambahkan bahwa pendidikan karakter di sekolah sangat terkait dengan manajemen atau pengelolaan sekolah (perencanaan, pelaksanaan, dan pengendalian). Senada dengan pendapat Masnur, Nata (2017: 135) menjelaskan bahwa jika program pendidikan dan pembinaan akhlak itu dirancang dengan baik, sistematik dan dilaksanakan dengan sungguhsungguh, maka akan menghasilkan anak-anak atau orang-orang yang baik akhlaknya.

Berdasarkan berbagai pendapat di atas sekolah sebagai lembaga pendidikan harus melaksanakan tugas dan fungsinya dengan baik, dan sekolah juga harus menyusun program dan membangun sistem yang baik untuk mengembangkan pendidikan karakter peserta didik dan seluruh warga sekolah. 
Sebagaimana telah dibahas sebelumnya, Pasal 6 (1) Peraturan Menteri Pendidikan dan Kebudayaan Republik Indonesia Nomor 20 Tahun 2018, dijelaskan tentang pelaksanaan Penguatan Pendidikan Karakter (PPK) di sekolah dengan pendekatan berbasis: kelas, budaya sekolah, dan masyarakat. Adapun implementasi dari ketiga basis pendekatan tersebut adalah sebagai berikut:

1) Pendekatan Berbasis Kelas (Pasal 6 (2)), dilakukan dengan cara:

a) Mengintegrasikan nilai-nilai karakter dalam proses pembelajaran secara tematik atau terintegrasi dalam mata pelajaran sesuai dengan isi kurikulum;

b) Merencanakan pengelolaan kelas dan metode pembelajaran/pembimbingan sesuai dengan karakter peserta didik;

c) Melakukan evaluasi pembelajaran/ pembimbingan; dan

d) Mengembangkan kurikulum muatan lokal sesuai dengan kebutuhan dan karakteristik daerah, satuan pendidikan, dan peserta didik. 
2) Pendekatan Berbasis Budaya Sekolah (Pasal 6 (3)) dilakukan dengan cara:

a) menekankan pada pembiasaan nilai-nilai utama dalam keseharian sekolah;

b) memberikan keteladanan antar warga sekolah;

c) melibatkan seluruh pemangku kepentingan pendidikan di sekolah;

d) membangun dan mematuhi norma, peraturan, dan tradisi sekolah;

e) mengembangkan keunikan, keunggulan, dan daya saing sekolah sebagai ciri khas sekolah;

f) memberi ruang yang luas kepada peserta didik untuk mengembangkan potensi melalui kegiatan literasi; dan

g) khusus bagi peserta didik pada satuan pendidikan jenjang pendidikan dasar atau satuan pendidikan jenjang pendidikan menengah diberikan ruang yang luas untuk mengembangkan potensi melalui kegiatan ekstrakurikuler.

3) Pendekatan Berbasis Masyarakat (Pasal 6 (4)), melalui:

a) Memperkuat peranan orang tua sebagai pemangku kepentingan utama pendidikan dan Komite Sekolah sebagai lembaga 
partisipasi masyarakat yang menjunjung tinggi prinsip gotong royong;

b) Melibatkan dan memberdayakan potensi lingkungan sebagai sumber belajar seperti keberadaan dan dukungan pegiat seni dan budaya, tokoh masyarakat, alumni, dunia usaha, dan dunia industri; dan

c) Mensinergikan implementasi PPK dengan berbagai program yang ada dalam lingkup akademisi, pegiat pendidikan, lembaga swadaya masyarakat, dan lembaga informasi.

Sekolah merupakan sebuah ekosistem pendidikan yang terdiri dari kepala sekolah, pendidik, tenaga kependidikan, karyawan serta peserta didik. Dalam program PPK, fungsi dan peran dari masing-masing dipaparkan sebagai berikut (2017: 2224):

1) Pengawas Sekolah;

a) memberikan keteladanan kepada seluruh komunitas sekolah sebagai perwujudan dari pelaksanaan program PPK;

b) mengidentifikasi dan mengoptimalkan berbagai potensi/keunggulan sekolah binaan dalam implementasi PPK;

c) memetakan branding implementasi PPK di sekolah-sekolah binaan untuk dijadikan rujukan bagi sekolah binaan lain; 
d) mendampingi dan mendukung kepala sekolah, guru, dan peserta didik untuk mengimplementasikan nilai-nilai PPK sesuai dengan branding sekolah;

e) mengevaluasi implementasi PPK di sekolah binaan;

f) mendampingi penyusunan tindak lanjut hasil evaluasi implementasi PPK di sekolah binaan;

g) membantu menjelaskan secara komprehensif kepada pihak terkait/komunitas sekolah tentang konsep, tujuan, dan manfaat PPK; dan

h) memastikan PPK diterapkan secara utuh dan menyeluruh melalui implementasi kurikulum dan metode pembelajaran di sekolah binaan.

2) Kepala Sekolah/Ketua Yayasan Kepala Sekolah/Ketua Yayasan bersama dengan komunitas sekolah lainnya:

a) memberikan keteladanan kepada seluruh komunitas sekolah sebagai perwujudan dari pelaksanaan program PPK;

b) menyusun dan mengimplementasikan visi misi sekolah

c) menetapkan branding sekolah terkait pelaksanaan program PPK;

d) menyusun RKS dan RKAS yang mengakomodasi program PPK;

e) melaksanakan sosialisasi program PPK di satuan pendidikan;

f) mewujudkan budaya sekolah yang mendukung pelaksanaan program PPK; 
g) memfasilitasi pendidik dan tenaga kependidikan dalam mengimplementasikan program PPK;

h) mendampingi pendidik dan peserta didik dalam pelaksanaan program PPK;

i) mengoptimalkan fungsi MKKS dalam pelaksanaan Program PPK.

j) melaksanakan monitoring dan evaluasi pelaksanaan program PPK

k) melaksanakan tindak lanjut berdasarkan hasil monitoring dan evaluasi pelaksanaan program PPK; dan 12) membuat dokumentasi pelaksanaan kegiatan PPK

3) Pendidik

a) memberikan keteladanan kepada seluruh komunitas sekolah sebagai perwujudan dari pelaksanaan program PPK;

b) menyusun RPP, melaksanakan pembelajaran, dan penilaian yang mengintegrasikan nilai-nilai utama PPK;

c) menggunakan metode pembelajaran yang mengembangkan kemampuan berpikir kritis, kreatif, komunikatif, dan kolaboratif;

d) mendukung terbentuknya relasi yang baik antarpendidik. peserta didik, dan seluruh komunitas sekolah di dalam kelas maupun di luar kelas; 
e) membangun lingkungan belajar yang mengapresiasi dan menghargai keunikan individu

f) mengoptimalkan fungsi KKG dan MGMP untuk pengembangan pembelajaran berbasis PPK

g) mengembangkan kegiatan kokurikuler berbasis PPK;

h) melaksanakan program ekstrakurikuler berbasis PPK

i) mengoptimalkan peran dan fungsi bimbingan dan konseling dalam pelaksanaan program PPK; dan

j) melaksanakan monitoring dan evaluasi pelaksanaan program PPK

4) Tenaga Kependidikan

a) memberikan keteladanan kepada seluruh komunitas sekolah sebagai perwujudan dari pelaksanaan program PPK;

b) mendukung terbentuknya relasi yang baik antartenaga kependidikan, pendidik, pesertadidik, dan seluruh komunitas sekolah di dalam lingkungan satuan pendidikan; dan

c) mendukung pelaksanaan kegiatan intrakurikuler, kokurikuler, dan ekstrakurikuler berbasis PPK

5) Komite Sekolah

a) memberikan keteladanan kepada seluruh komunitas sekolah sebagai perwujudan dari pelaksanaan program PPK; 
b) mendukung pelaksanaan program PPK secara mandiri dan gotong royong;

c) mendukung pelaksanaan kegiatan intrakurikuler, kokurikuler, dan ekstrakurikuler berbasis PPK;

d) mendukung pelaksanaan kebijakan lima hari sekolah;

e) melaksanakan monitoring dan evaluasi pelaksanaan program PPK

f) menciptakan suasana rumah yang kondusif dalam penanaman nilainilai karakter; dan

g) melaksanakan monitoring dan evaluasi pelaksanaan program PPK.

Meskipun tidak berhubungan langsung dengan proses pembelajaran kepada peserta didik, pengawas sekolah dapat mendukung keberhasilan atau kekurangberhasilan penyelenggaraan pendidikan melalui peran dan fungsi yang diemban. Selain kepala sekolah, guru merupakan personalia penting dalam pendidikan karakter di sekolah. Sebagian besar interaksi yang terjadi di sekolah adalah interaksi peserta didik dengan guru.

Dalam program PPK, sosok guru memiliki multi fungsi sebagai guru masa kini. Seorang guru dituntut untuk menyiapkan 
anak didiknya memiliki kecakapan abad ke-21 yang bercirikan berfikir kritis dan analitis, kreatif dan inovatif, komunikatif serta kolaboratif. Fungsi guru adalah sebagai pengajar, artinya guru mampu menyampaikan mata pelajaran agar dimengerti dan dipahami anak didiknya. Guru sebagai katalisator, artinya guru mampu mengidentifikasi, menggali, dan mengoptimalkan potensi anak didik. Guru sebagai penjaga gawang, diartikan bahwa guru dapat membantu anak didik untuk mampu menyaring pengaruh negatif. Guru sebagai fasilitator, berarti guru mampu membantu anak didik dalam proses pembelajaran, menjadi teman diskusi dan bertukar fikiran. Dan guru sebagai penghubung, berarti bahwa guru mampu menghubungkan anak didik dengan sumbersumber belajar yang beragam; baik di dalam maupun di luar sekolah.

Pendidik merupakan teladan bagi siswa. Dalam Undang-Undang Guru dan Dosen No. 14 tahun 2005, guru didefinisikan sebagai pendidik profesional dengan tugas utama mendidik, mengajar, membimbing, mengarahkan, melatih, menilai, dan mengevaluasi peserta didik pada pendidikan usia dini jalur pendidikan formal, pendidikan dasar, dan pendidikan menengah. 
Koesoema (2015: 53) menyimpulkan bahwa pendidikan karakter yang efektif hanya akan dapat dimulai ketika masingmasing anggota komunitas di dalam sekolah merasa sebagai satu keluarga. Pendapat Koesoema mengisyaratkan bahwa lingkungan sekolah yang sarat akan nilai persaudaraan dan kekeluargaan dapat menjadi modal awal bagi pengembangan pendidikan karakter di sekolah.

\section{c. Pendekatan dan Langkah-langkah Pendidikan Karakter di Sekolah}

Mulyasa (2018:3) memaknai pendidikan karakter lebih tinggi dari pendidikan moral. Hal itu karena pendidikan karakter berkaitan dengan menanamkan kebiasaan (habit) tentang hal-hal yang baik dalam kehidupan, agar peserta didik memiliki kesadaran, dan pemahaman yang tinggi, serta kepedulian dan komitmen untuk menerapkan kebajikan dalam kehidupan seharihari.

Menurut Zubaedi (2011:14) ada tiga hal yang bisa dilakukan dalam menanamkan pendidikan karakter, yaitu (1) mengintegrasikan butir-butir nilai karakter pada semua mata pelajaran, muatan lokal dan kegiatan pengembangan diri, (2) melalui kegiatan pembiasaan dalam kehidupan sehari-hari di 
sekolah atau Sekolah/Madrasah, baik dari segi pelayanan, pengelolaan dan pengajaran di Sekolah/Madrasah, dan (3) meningkatkan kerjasama antara pihak sekolah, orang tua peserta didik dan masyarakat. Hal ini bertujuan untuk membudayakan atau membiasakan nilai-nilai karakter di lingkungan sekolah, lingkungan rumah dan lingkungan masyarakat.

Akan tetapi, pada kenyataannya, ketiga strategi penerapan pendidikan karakter tersebut belum terlaksana dengan baik di beberapa sekolah dan Madrasah. Sebab, dewasa ini, fokus sebagian lembaga pendidikan masih pada pembekalan ilmu pengetahuan dan skill untuk bekerja agar peserta didik mampu bersaing dalam mempertahankan hidupnya. Sedangkan, pembentukan watak, karakter atau akhlak, hampir tidak diperhatikan dan terlupakan, padahal karakter inilah yang akan menentukan dan mengarahkan masa depan peserta didik yang lebih cerah dan lebih baik.

Sudrajat (2011:41-42) menggambarkan bahwa dua cara untuk membangun karakter, dilakukan dengan: 1) melatih siswa membiasakan perilaku sesuai dengan nilai-nilai, sebagai aktualisasi potensi spiritual (SQ) dalam kehidupan sehari-hari melalui pembiasaan. 2). Meningkatkan kecerdasan siswa sehingga pemahaman-pemahaman atas nilai-nilai akhlak mulia, 
dapat diterima dan diorganisasikan dalam sistem yang disebut sebagai penghayatan atau internalisasi.

Pada intinya pendidikan karakter di sekolah dapat dilaksanakan melalui pembiasaan nilai-nilai baik dalam kegiatankegiatan yang ada di sekolah, baik itu di dalam kelas maupun di lingkungan sekolah dan juga melalui keikutsertaan seluruh warga sekolah.

Cara menanamkan nilai-nilai karakter di sekolah dibagi ke dalam beberapa bentuk kegiatan, antara lain kegiatan rutin, kegiatan spontan, keteladanan dan juga pengondisian (Wibowo, 2012: 84-91). Kegiatan rutin yaitu kegiatan yang dilakukan peserta didik secara terus menerus dan konsisten setiap saat. Seperti kegiatan upacara hari Senin, piket kelas, shalat berjamaah, berdo"a sebelum pelajaran dimulai dan diakhiri, dan mengucapkan salam apabila bertemu guru, tenaga pendidik, dan teman. Adapun kegiatan spontan adalah kegiatan yang dilakukan peserta didik secara spontan pada saat itu juga, seperti mengumpulkan sumbangan untuk korban bencana. Keteladanan merupakan perilaku, sikap guru, tenaga kependidikan dan peserta didik dalam memberikan contoh melalui tindakantindakan yang baik sehingga diharapkan menjadi panutan bagi peserta didik lain. Misalnya kedisiplinan guru, kebersihan, kerapihan, perhatian, 
jujur, dan kerja keras. Sedangkan Pengkondisian yaitu penciptaan kondisi yang mendukung keterlaksanaan pendidikan karakter, misalnya kebersihan badan dan pakaian, toilet yang bersih, tempat sampah, halaman yang hijau dengan pepohonan, poster kata-kata bijak di sekolah dan di dalam kelas.

Selain itu, Fitri (2017: 52) mengemukakan lima langkah yang bisa ditempuh untuk pendidikan karakter, yaitu:

1) Merancang dan merumuskan karakter yang ingin dibelajarkan pada siswa;

2) Menyiapkan sumber daya dan lingkungan yang dapat mendukung program pendidikan karakter;

3) Meminta komitmen bersama (Kepala Sekolah, Guru, Karyawan, dan Wali Murid) dalam pelaksanaan dan pengawasan;

4) Melaksanakan pendidikan karakter secara kontinu dan konsisiten;

5) Melakukan evaluasi terhadap program yang sudah ada dan sedang berlangsung.

Agus (2017: 59) juga menambahkan tentang tahap-tahap pembentukan karakter seperti gambar berikut: 


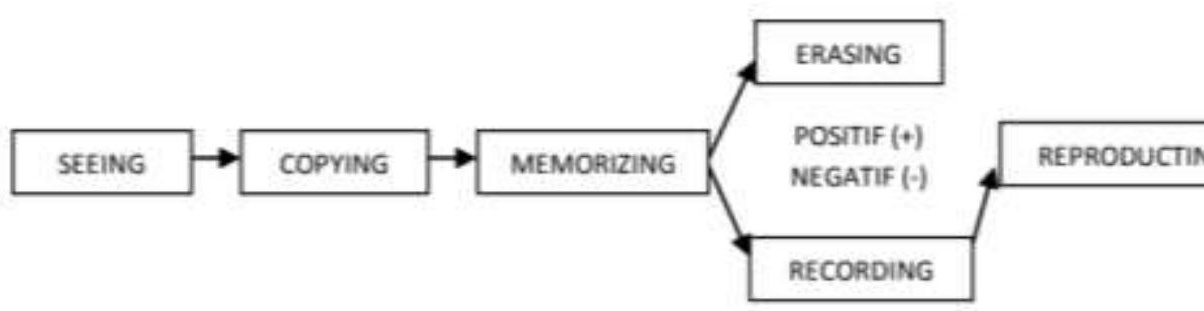

Gambar 2.6 Tahap Pembentukan Karakter

Gambar di atas dapat menjadi acuan bahwa apa yang dilakukan peserta didik, baik atau buruk, diawali dengan proses melihat, mengamati, meniru, mengingat, menyimpan kemudian mengeluarkannya kembali menjadi perilaku sesuai dengan ingatan yang tersimpan dalam otaknya. Untuk itu sekolah yang baik harus mampu menciptakan lingkungan yang baik dan kondusif guna menjadikan segala sesuatu di sekolah yang dapat dilihat dan didengar oleh peserta didik sarat dengan nilai-nilai baik sesuai dengan nilai karakter yang diharapkan dapat terbetuk pada peserta didik.

Langkah awal yang wajib dilakukan bila ingin berhasil melaksanakan pendidikan karakter adalah melibatkan seluruh anggota komunitas untuk memiliki persamaan tujuan dalam bersikap dan bertindak (Koesoema, 2015: 56). Setiap individu dalam sekolah memiliki perbedaan pengalaman khas yang 
membentuk mereka sekarang. Jika perbedaan yang ada tidak dikelola dengan baik dapat menghambat proses dan keberhasilan pendidikan karakter di sekolah.

\section{B. Pendidikan Karakter dalam Keluarga}

Jika sosialisasi dan pendidikan sangat penting dalam pendidikan karakter, maka sejak kapan sebaiknya hal itu dilakukan? Menurut Thomas Lickona yang dikutip Megawangi, pendidikan karakter perlu dilakukan sejak usia dini (Ratna Megawangi, 2003). Erik Erikson-yang terkenal dengan teori Psychososial Development - juga menyatakan hal yang sama. Erikson menyebutkan bahwa anak adalah gambaran awal manusia menjadi manusia, yaitu masa di saat kebajikan berkembang secara perlahan tapi pasti. Jika dasar-dasar kebajikan gagal ditanamkan pada anak di usia dini, dia akan menjadi orang dewasa yang tidak memiliki nilai-nilai kebajikan (Erik $\mathrm{H}$. Erikson, 2010). Selanjutnya, Hurlock menyatakan bahwa usia dua tahun pertama dalam kehidupan adalah masa kritis bagi pembentukan pola penyesuaian personal dan social (Elizabeth B. Hurlock, 2009). Oleh karena itu, bagi seorang anak, keluarga 
merupakan tempat pertama dan utama bagi pertumbuhan dan perkembangannya.

Selain psikolog, para sosiolog juga meyakini bahwa keluarga memiliki peran penting dalam menentukan kemajuan suatu bangsa, sehingga mereka berteori bahwa keluarga adalah unit yang penting sekali dalam masyarakat, sehingga jika keluarga-keluarga yang merupakan fondasi masyarakat lemah, maka masyarakat pun akan lemah. Oleh karena itu, para sosiolog meyakini bahwa berbagai masalah masyarakat, seperti kejahatan seksual dan kekerasan yang merajalela, serta segala macam kebobrokan di masyarakat merupakan akibat dari lemahnya institusi keluarga.Apabila keluarga gagal untuk mengajarkan kejujuran, semangat, keinginan untuk menjadi yang terbaik, dan kemampuan-kemampuan dasar, maka akan sulit sekali bagi institusi-institusi lain untuk memperbaiki kegagalan itu.Aspek penting dalam pembentukan karakter anak dalam keluarga adalah terpenuhinya tiga kebutuhan dasar anak, yaitu: maternal bonding, rasa aman, dan stimulasi fisik dan mental.Maternal bonding (kelekatan psikologis dengan ibunya) merupakan dasar penting dalam pembentukan karakter anak karena aspek ini berperan dalam pembentukan dasar kepercayaan kepada orang lain (trust) pada anak. Kelekatan ini membuat anak merasa diperhatikan dan 
menumbuhkan rasa aman sehingga menumbuhkan rasa percaya. Menurut Erikson, dasar kepercayaan yang ditumbuhkan melalui hubungan ibu-anak pada tahun-tahun pertama kehidupan anak akan memberi bekal bagi kesuksesan anak dalam kehidupan sosialnya ketika ia dewasa. Artinya, ikatan emosional yang erat antara ibu-anak di usia awal dapat membentuk kepribadian yang baik pada anak (Elizabeth B. Hurlock, 2009).

Kebutuhan akan rasa aman yaitu kebutuhan anak akan lingkungan yang stabil dan aman. Kebutuhan ini penting bagi pembentukan karakter anak karena lingkungan yang berubahubah akan membahayakan perkembangan emosi bayi. Pengasuh yang berganti-ganti juga akan berpengaruh negatif pada perkembangan emosi anak. Menurut Megawangi, normal bagi seorang bayi untuk mencari kontak dengan hanya satu orang (biasanya ibu) pada tahap-tahap awal masa bayi. Kekacauan emosi anak yang terjadi karena tidak adanya rasa aman ini diduga oleh para ahli gizi berkaitan dengan masalah kesulitan makan pada anak.Tentu saja hal ini tidak kondusif bagi pertumbuhan anak yang optimal (Ratna Megawangi, 2003).

Kebutuhan akan stimulasi fisik dan mental juga merupakan aspek penting dalam pembentukan karakter anak. Tentu saja hal ini membutuhkan perhatian yang besar dari orang 
tua dan reaksi timbal balik antara ibu dan anaknya.Seorang ibu yang sangat perhatian (yang diukur dari seringnya ibu melihat mata anaknya, mengelus, menggendong, dan berbicara kepada anaknya) terhadap anaknya yang berusia usia di bawah enam bulan akan mempengaruhi sikap bayinya, sehingga menjadi anak yang gembira, antusias mengeksplorasi lingkungannya, dan menjadikannya anak yang kreatif. Selain itu, keberhasilan keluarga dalam menanamkan nilai-nilai kebajikan (karakter) pada anak sangat tergantung pada jenis pola asuh yang diterapkan orang tua pada anaknya. Pola asuh dapat didefinisikan sebagai pola interaksi antara anak dengan orangtua yang meliputi pemenuhan kebutuhan fisik (seperti makan, minum dan lain-lain) dan kebutuhan psikologis (seperti rasa aman, kasih sayang dan lain-lain), serta sosialisasi norma-norma yang berlaku di masyarakat agar anak dapat hidup selaras dengan lingkungannya.

Pola asuh juga meliputi pola interaksi orang tua dengan anak dalam rangka pendidikan karakter anak.Melalui pola asuh yang dilakukan oleh orang tua, anak belajar tentang banyak hal, termasuk karakter.Tentu saja pola asuh otoriter (yang cenderung menuntut anak untuk patuh terhadap segala keputusan orang tua) dan pola asuh permisif (yang cenderung memberikan kebebasan penuh pada anak untuk berbuat) sangat berbeda dampaknya 
dengan pola asuh demokratis (yang cenderung mendorong anak untuk terbuka, namun bertanggung jawab dan mandiri) terhadap hasil pendidikan karakter anak.Artinya, jenis pola asuh yang diterapkan oleh orang tua terhadap anaknya menentukan keberhasilan pendidikan karakter anak oleh keluarga. (Samrin, 2016)

\section{a. Penguatan Karakter dalam Keluarga}

Pendidikan adalah tanggung jawab bersama antara keluarga, sekolah, masyarakat atau pemerintah. Sekolah sebagai pembentuk kelanjutan pendidikan dalam keluarga, sebab pendidikan yang pertama dan utama diperoleh anak adalah dalam keluarga.

Menurut Ali bin Abi Thalib (RA), seorang sahabat utama Nabi Muhammad SAW., menganjurkan: Ajaklah anak pada usia sejak lahir sampai tujuh tahun bermain, ajarkan anak peraturan atau adab ketika mereka berusia tujuh sampai empat belas tahun, pada usia empat belas sampai dua puluh satu tahun jadikanlah anak sebagai mitra orang tuanya.

Ketika anak masuk ke sekolah mengikuti pendidikan formal, dasar-dasar karakter ini sudah terbentuk. Anak yang 
sudah memiliki watak yang baik biasanya memiliki achievement motivation yang lebih tinggi karena perpaduan antara intelligence quotient, emosional quotient dan spiritual quotient sudah terformat dengan baik.

Peran orang tua dalam mewujudkan kepribadian anak antara lain:

1) Kedua orang tua harus mencintai dan menyayangi anak-anaknya

2) Kedua orang tua harus menjaga ketenangan lingkungan rumah dan menyiapkan ktenangan jiwa anak-anak

3) Saling menghormati antara kedua orang tua dan anak-anak

4) Mewujudkan kepercayaan

5) Mengadakan kumpulan dan rapat keluarga (kedua orang tua dan anak)

Selain itu kedua orang tua harus mengenalkan mereka tentang masalah keyakinan, akhlak dan hukum-hukum fikih serta kehidupan manusia. Yang paling penting adalah bahwa ayah dan ibu adalah satusatunya teladan yang pertama bagi anak-anaknya dalam pembentukan kepribadian, begitu juga anak yang secara tidak sadar mereka akan terpengaruh, maka kedua orang tua berperan sebagai teladan bagi mereka baik teladan pada tataran teoritis maupun praktis. 
Seperti yang telah dijelaskan, bahwa lingkungan rumah dan keluarga memiliki andil yang sangat besar dalam pembentukan perilaku anak. Untuk itu pastilah ada usaha yang harus dilakukan terutama oleh pihak-pihak yang terkait di dalamnya sehingga mereka akan memiliki tanggung jawab dalam hal ini. Beberapa contoh kebiasaan yang dapat dilakukan di lingkungan keluarga:

1) Membiasakan anak bangun pagi,

2) Mengatur tempat tidur dan berolahraga

3) Membiasakan anak mandi dan berpakaian bersih

4) Membiasakan anak turut membantu mengerjakan tugas-tugas rumah

5) Membiasakan anak mengatur dan memelihara barang-barang yang dimilikinya

6) Membiasakan dan mendampingi anak belajar/mengulang pelajaran/mengerjakan tugas sekolahnya

7) Membiasakan anak pamit jika keluar rumah

8) Membiasakan anak mengucap salam saat keluar dari dan pulang ke rumah

9) Menerapkan pelaksanaan ibadah shalat sendiri dan berjamaah

10) Mengadakan pengajian Alquran dan ceramah agama dalam keluarga 
11) Menerapkan musyawarah dan mufakat dalam keluarga sehingga dalam diri anak akan tumbuh jiwa demokratis

12) Membiasakan anak bersikap sopan santun kepada orang tua dan tamu

13) Membiasakan anak menyantuni anak yatim dan fakir miskin

Kendala-kendala yang dihadapi dalam keluarga :

1) Tidak ada/kurangnya keteladanan/contoh penerapan yang diberikan oleh orang tua.

2) Orang tua atau salah satu anggota keluarga (orang dewasa) yang tidak konsisten dalam melaksanakan usaha yang sedang diterapkan

3) Kurang terpenuhinya kebutuhan anak dalam keluarga, baik secara fisik maupun psikhis sebab ada ungkapan yang menyatakan bahwa 'kepatuhan anak berbanding sama dengan kasih sayang yang diterimanya.

4) Tempat tinggal yang tidak menetap

Rumah tangga dan keluarga sebagai lingkungan pembentukan watak dan pendidikan karakter pertama dan utama mestilah diberdayakan kembali. Sebagaimana disarankan Phillips, 
keluarga hendaklah kembali menjadi "school of love", sekolah untuk kasih sayang (Phillips 2000: 11).

Dalam perspektif Islam, keluarga sebagai "school of love" dapat disebut sebagai "Sekolah/Madrasah mawaddah wa rahmah, tempat belajar yang penuh cinta sejati dan kasih sayang. Islam memberikan perhatian yang sangat besar kepada pembinaan keluarga (usrah). Keluarga merupakan basis dari (ummah) bangsa; dan karena itu keadaan keluarga sangat menentukan keadaan ummah itu sendiri. Bangsa terbaik (khayr ummah) yang merupakan (ummah wahidah) bangsa yang satu dan (ummah wasath) bangsa yang moderat, sebagaimana dicita-citakan Islam hanya dapat terbentuk melalui keluarga yang dibangun dan dikembangkan atas dasar mawaddah warahmah.

Berdasarkan sebuah hadis yang diriwayatkan Anas RA., keluarga yang baik memiliki empat ciri. Pertama; keluarga yang memiliki semangat (ghirah) dan kecintaan untuk mempelajari dan menghayati ajaran-ajaran agama dengan sebaik-baiknya untuk kemudian mengamalkan dan mengaktualisasikannya dalam kehidupan seharihari. Kedua, keluarga di mana setiap anggotanya saling menghormati dan menyayangi; saling asah dan asuh. Ketiga, keluarga yang dari segi nafkah (konsumsi) tidak berlebih- 
lebihan; tidak ngoyo atau tidak serakah dalam usaha mendapatkan nafkah; sederhana atau tidak konsumtif dalam pembelanjaan. Keempat, keluarga yang sadar akan kelemahan dan kekurangannya; dan karena itu selalu berusaha meningkatkan ilmu dan pengetahuan setiap anggota keluarganya melalui proses belajar dan pendidikan seumur hidup (life long learning), min almahdi ila al-lahdi. Berikut ini pembinaan karakter dalam keluarga:

a) Pembinaan Karakter Anak yang dilakukan oleh Keluarga

Secara etimologi pengasuhan berasal dari kata "asuh" yang artinya, pemimpin, pengelola, membimbing. Oleh kerena itu mengasuh disini adalah mendidik dan memelihara anak, mengurus makan, minum, pakaiannya dan keberhasilannya dari periode awal hingga dewasa. Pada dasarnya, tugas dasar perkembangan anak adalah mengembangkan pemahaman yang benar tentang bagaimana dunia ini bekerja. Dengan kata lain, tugas utama seorang anak dalam perkembangannya adalah mempelajari "aturan main" segala aspek yang ada di dunia ini. Berbagai pola asuh orang tua dapat mempengaruhi kreativitas anak antara lain, lingkungan fisik, lingkungan sosial pendidikan internal dan eksternal. Intensitas kebutuhan anak untuk mendapatkan bantuan dari orang tua bagi kepemilikan dan 
pengembangan dasar-dasar kreativitas diri, menunjukan adanya kebutuhan internal yaitu manakala anak masih membutuhkan banyak bantuan dari orang tua untuk memiiliki dan mengembangkan dasar dasar kreativitas diri (berdasarkan naluri), berdasarkan nalar dan berdasarkan kata hati. Dari hasil penelitian bahwa bila orang tua berperan dalam pendidikan, anak akan menunjukan peningkatan prestasi belajar, diikuti dengan perbaikan sikap, stabilitas sosioemosional, kedisiplinan, serta aspirasi anak untuk belajar sampai ke jenjang paling tinggi, bahkan akan membantu anak ketika ia telah bekerja dan berkeluarga.

b) Keluarga sebagai Wahana Pertama dan Utama Pendidikan

Para sosiolog meyakini bahwa keluarga memiliki peran penting dalam menentukan kemajuan suatu bangsa, sehingga mereka berteori bahwa keluarga adalah unit yang penting sekali dalam masyarakat. Oleh karena itu para sosiolog yakin, segala macam kebobrokan masyarakat merupakan akibat lemahnya institusi keluarga. Bagi seorang anak keluarga merupakan tempat pertama dan utama bagi pertumbuhan dan perkembangnnya. Menurut resolusi Majelis Umum PBB, fungsi utama keluarga adalah sebagai wahana untuk mendidik, mengasuh dan 
mensosialisasikan anak, mengembangkan kemampuan seluruh anggotanya agar dapat menjalankan fungsinya di masyarakat dengan baik, serta, memberikan kepuasan dan lingkungan yang sehat guna tercapainya keluarga sejahtera". Keluarga merupakan tempat yang paling awal dan efektif untuk menjalankan fungsi departemen kesehatan, pendidikan adan kesejahteraan. Jika keluarga gagal untuk mengajarkan kejujuran, semangat, keinginan untuk menjadi yang terbaik, dan menguasai kemampuan- kemampuan dasar, maka akan sulit sekali bagoi institusi lain untuk memperbaiki kegagalannya. Karena kagagalan keluarga dalam membentuk karakter anak akan berakibat pada tumbuhnya masyarakat yang berkarakter buruk atau tidak berkarakter. Oleh karena itu setiap keluarga harus memiliki kesadaran bahwa karakter bangsa sangat tergantung pada pendidikan karakter anak di rumah.

c) Pola Asuh Menentukan Keberhasilan Pendidikan Anak dalam Keluarga

Keberhasilan keluarga dalam menanamkan nilai-nilai kebijakan pada anak sangat tergantung pada jenis pola asuh yang 
diterapkan orang tua pada anaknya. Pola asuh dapat didefinisikan sebagai pola interaksi antara anak dengan orang tua yang meliputi pemenuhan kebutuhan fisik dan kebutuhan psikologis, serta norma norma yang berlaku di masyarakat.agar anak dapat hidup selaras dengan lingkungannya. Beberapa macam contoh pola asuh:

1) Pola asuh otoriter, yaitu mempunyai ciri, kekuasan orang tua dominan, anak tidak diakui sebagai pribadi, control terhadap tingkah laku anak sangat ketat, orang tua menghukum anak jika tidak patuh.

2) Pola asuh demokratis, kerjasama antara orang tua- anak, anak diakui sebgai pribadi, ada bimbingan dan penngarahan dari orang tua, control orang tua tidak kaku.

3) Pola asuh permisif, mempunyai ciri, dominasi oleh anak, sikap longgar atau kebebasan dari orang tua, kontrol dan perhatian orang tua sangat kurang. Melalui pola asuh yang dilakukan orang tua anak akan belajar banyak hal, termasuk karakter. Artinya jenis pola asuh yang ditetapkan orang tua terhadap anaknya menentukan keberhasilan pendidikan karakter anak oleh keluarga. 
d) Kesalahan keluarga dalam mendidik anak mempengaruhi perkembangan kecerdasan emosi anak

Kesalahan dalam pengasuhan anak akan berakibat pada kegagalan dalam pembentukan karakter yang baik. Beberapa kesalahan orang tua dalam mendidik anak dapat mempengaruhi kecerdasan emosi anak, diantaranya adalah:

1) Orang tua kurang menunjukan ekspresi kasih sayang baik secara verbal maupun fisik

2) Kurang meluangkan waktu untuk anak

3) Orang tua bersikap kasar secara verbal, misalnya, menyindir anak, mengecilkan anak dan berkata kata kasar

4) Bersikap kasar secara fisik, misalnya memukul, mencubit atau memberikan hukuman badan lainnya.

5) Orang tua terlalu memaksa anak untuk menguasai kemampuan kognitif secara dini

6) Orang tua tidak menanamkan karakter yang baik pada anak

Dampak salah asuh di atas akan menimbulkan anak yang mempunyai kepribadian yang bermasalah atau kecedasan emosi yang rendah, seperti:

a). Anak menjadi tak acuh, tidak menerima persahabatan, rasa tidak percaya pada orang lain dll. 
b). Secara emosionil tidak responsif

c). Berprilaku agresif

d). Menjadi minder

e). Selalu berpandangan negatif

f). Emosi tidak stabil

g). Emosional dan intelektual tidak seimbang dan lain-lain. (Subianto, 2013) 


\section{BAB III}

\section{SUMBER NILAI-NILAI PENDIDIKAN KARAKTER}

Teridentifikasinya 18 nilai pembentuk karakter oleh Pusat Kurikulum Kementerian Pendidikan dan Kebudayaan (Kemendikbud) merupakan hasil kajian empirik yang bersumber dari agama, Pancasila, budaya, dan tujuan pendidikan Nasional (Samani dan Hariyanto, 2011: 9). Berikut penjelasannya:

\section{A. Agama}

Suhamijaya dkk menjelaskan bahwa mantan Presiden RI Pertama Soekarno berulang-ulang menegaskan "Agama adalah unsur mutlak dalam National and Character Building" (Majid dan Andayani, 2011:61).

Pendidikan karakter yang melekat pada masyarakat Indonesia di masa lalu disebabkan berbagai faktor, antara lain faktor agama. Sejarah mencatat bahwa di Indonesia pada ribuan tahun yang lalu telah ada berbagai macam agama, seperti Hindu, Budha, Islam, Kristen, Konghucu, dan sebagainya. Di pulau Jawa, terdapat sembilan orang Wali (Wali Songo) sebagai juru dakwah yang mengajak masyarakat kembali bertauhid meng- 
Esakan Allah SWT. Para wali tersebut mengajarkan pendidikan karakter dengan berbagai metode dan pendekatan ke dalam jiwa, pikiran, dan perilaku masyarakat melalui kegiatan dakwah, kesenian, pernikahan, perdagangan, pertanian, pengobatan, dan lain sebagainya.

Dalam ajaran Islam, istilah karakter dikenal dengan akhlak. Ayat-ayat Allah SWT dalam al-Qur"ean menyebutkan berbagai bentuk perbuatan yang termasuk akhlak mulia. Hal itu menunjukkan betapa Islam sangat memperhatikan masalah pembinaan akhlak. Dalam QS. An-Nahl ayat 97 Allah SWT berfirman:

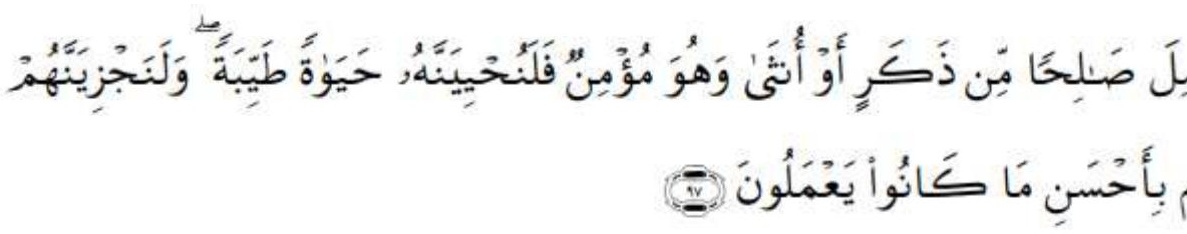

Artinya: "Barangsiapa yang mengerjakan amal shaleh, baik laki-laki maupun perempuan dalam keadaan beriman, maka sesungguhnya akan Kami berikan kepadanya kehidupan yang baik dan sesungguhnya akan Kami beri balasan kepada mereka dengan pahala yang lebih baik dari apa yang telah mereka kerjakan". 
Amal shaleh yang dimaksud pada ayat di atas adalah perbuatan yang mengikuti petunjuk kitabullah dan sunnah NabiNya (Ibnukatsironline.com). Nata (2017:59) menambahkan bahwa orang yang melakukan berbagai perbuatan baik yang diperintahkan Tuhan (Allah SWT) itu, akan mendapatkan berbagai keberuntungan yang lebih besar baik di dunia ini maupun di akhirat. Dengan kata lain, orang yang beriman diharapkan mampu melaksanakan perbuatan-perbuatan yang baik sesuai petunjuk Al-Qur"ean dan ajaran Rasulullah SAW. Adapun larangan-larangan yang Allah terangkan dalam al-Qur'ean ditujukan untuk kebaikan dan keselamatan manusia itu sendiri.

Selain ayat di atas, bukti lain bahwa akhlak menempati posisi yang istimewa dan sangat penting yaitu bahwa Rasulullah SAW menempatkan penyempurnaan akhlak yang mulia sebagai misi pokok risalah Islam. Hal itu termaktub jelas dalam sabda beliau:

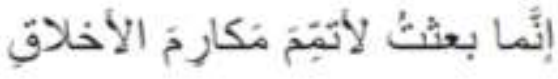

Artinya: "Sesungguhnya aku diutus untuk menyempurnakan akhlak yang mulia."

(HR. Al Baihaqi, dishahihkan Al Albani dalam Silsilah Ash Shahihah, no. 45). 
Maksud dari ungkapan "menyempurnakan" pada bunyi hadits di atas, Rasulullah SAW mengakui adanya akhlak atau karakter mulia yang diwarisi para Nabi, para filosof, dan pujangga di masa lalu (sebelum Islam) (Nata, 2017: 297). Pendapat Nata tersebut menjelaskan bahwa pendidikan karakter/akhlak dalam Islam merupakan penyempurnaan dari nilai-nilai akhlak yang sudah ada sebagai warisan para Nabi dan filosof-filosof terdahulu.

Bukti lain dari keistimewaan akhlak yaitu hadits Rasulullah SAW yang menyatakan kesempurnaan iman seseorang terikat pada kebaikan akhlaknya yaitu:

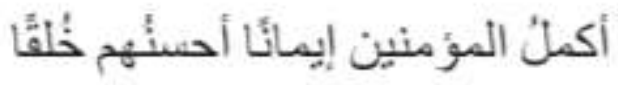

Artinya: "Kaum Mu"minin yang paling sempurna imannya adalah yang paling baik akhlaknya” (HR. Tirmidzi no. 1162, ia berkata: "hasan shahih").."

Ayat al-Qurean dan dua hadits di atas cukup mewakili untuk dapat menunjukkan betapa pentingnya akhlak/adab/karakter bagi manusia, terutama sebagai ciri kesempurnaan iman seorang mukmin. Nata (2017: 35) 
menjelaskan bahwa Ibnu Khaldun seorang ilmuwan Muslim yang ahli dalam bidang Ilmu agama dan Sosiologi menyatakan bahwa manusia adalah makhluk budaya yang kesempurnaannya baru akan terwujud manakala ia berinteraksi dengan lingkungan sosialnya. Ia menunjukkan tentang perlunya pembinaan manusia, termasuk dalam pembinaan akhlaknya. Majid dan Andayani (2011: 29) turut menegaskan bahwa misi utama Rasulullah SAW dalam mendidik manusia adalah untuk mengupayakan pembentukan akhlak yang baik (good character).

Majid dan Andayani (2011: 60) menambahkan bahwa akhlak Islam adalah akhlak yang benar-benar memelihara eksistensi manusia sebagai makhluk terhormat sebagai fitrahnya. Rasulullah SAW bersabda: "kamu tidak bisa memperoleh simpati semua orang dengan hartamu, tetapi dengan wajah yang menarik (simpati) dan dengan akhlak yang baik (HR. Abu Yu'la dan AlBaihaqi).

Dari ulasan di atas, secara jelas dapat disimpulkan bahwa ajaran agama Islam merupakan sumber nilai-nilai kebaikan yang harus dipelajari, diketahui, dipahami, dan dapat diimplementasikan dalam kehidupan seorang yang beriman dalam hubungannya kepada Allah SWT dan kepada sesama 
manusia. Begitupun menjauhi larangan-larangan-Nya, agar manusia selalu berada dalam kebaikan dan keselamatan.

\section{a. Pendidikan Karakter Berbasis Nilai Religius}

Ada empat jenis karakter yang selama ini dikenal dan dilaksanakan dalam proses pendidikan, yaitu sebagai berikut:

1. Pendidikan karakter berbasis nilai religius, yang merupakan kebenaran wahyu Tuhan (konservasi moral).

2. Pendidikan karakter berbasis nilai budaya, antara lain yang berupa budi pekerti, Pancasila, apresiasi sastra, keteladanan tokoh-tokoh sejarah dan para pemimpin bangsa (konservasi lingkungan).

3. Pendidikan karakter berbasis lingkungan (konservasi lingkungan)

4. Pendidikan karakter berbasis potensi diri, yaitu sikap pribadi, hasil proses kesadaran pemberdayaan potensi diri yang diarahkan untuk meningkatkan kualitas pendidikan (konservasi humanis).

Secara spesifik, pendidikan karakter yang berbasis nilai religius mengacu pada nilai-nilai dasar yang terdapat dalam agama (Islam). Nilai-nilai karakter yang menjadi prinsip dasar pendidikan karakter banyak kita temukan dari beberapa sumber, 
di antaranya nilai-nilai yang bersumber dari keteladanan Rasulullah yang terjewantahkan dalam sikap dan perilaku seharihari beliau, yakni shiddîq (jujur), amânah (dipercaya), tablîgh (menyampaikan dengan transparan), fathânah (cerdas). Berikut akan dijelaskan secara lebih rinci dari keempat sifat tersebut.

Shiddî $q$ adalah sebuah kenyataan yang benar yang tercermin dalam perkataan, perbuatan atau tindakan dan keadaan batinnya. Pengertian shiddîq ini dapat dijabarkan ke dalam butirbutir: a) memiliki sistem keyakinan untuk merealisasikan visi, misi dan tujuan; dan b) memiliki kemampuan kepribadian yang mantap, stabil, dewasa, arif, jujur, dan berwibawa, menjadi teladan bagi peserta didik dan berakhlak mulia.

Amânah adalah sebuah kepercayaan yang harus diemban dalam mewujudkan sesuatu yang dilakukan dengan penuh komitmen, kompeten, kerja keras dan konsisten. Pengertian amanah ini dapat dijabarkan ke dalam butir-butir: a) rasa memiliki dan tanggung jawab yang tinggi; b) memiliki kemampuan mengembangkan potensi secara optimal; c) memiliki kemampuan mengamankan dan menjaga kelangsungan hidup; dan d) memiliki kemampuan membangun kemitraan dan jaringan. 
Tablîgh adalah sebuah upaya merealisasikan pesan atau misi tertentu yang dilakukan dengan pendekatan atau metode tertentu. Jabaran pengertian ini diarahkan pada: a) memiliki kemampuan merealisasikan pesan atau misi; b) memiliki kemampuan berinteraksi secara efektif; dan c) memiliki kemampuan menerapkan pendekatan dan metodik yang tepat.

Fathânah adalah sebuah kecerdasan, kemahiran, atau penguasaan bidang tertentu yang mencakup kecerdasan intelektual, emosional dan spiritual. Karakteristik jiwa fathânah meliputi arif dan bijak, integritas tinggi, kesadaran untuk belajar, sikap proaktif, orientasi kepada Tuhan, terpercaya dan ternama, menjadi yang terbaik, empati dan perasaan terharu, kematangan emosi, keseimbangan, jiwa penyampai misi, dan jiwa kompetisi. Sifat fathânah ini dapat dijabarkan ke dalam butir-butir: a) memiliki kemampuan adaptif terhadap perkembangan dan perubahan zaman; b) memiliki kompetensi yang unggul, bermutu dan berdaya saing; dan c) memiliki kecerdasan intelektual, emosi, dan spiritual.

Di samping itu sumber lainnya dapat juga ditemukan dalam teksteks agama, baik al-Qur'an, hadits, maupun kata-kata hikmah para ulama. Dalam teks-teks agama tersebut banyak 
ditemukan anjuran untuk bersikap/berperilaku terpuji (akhlak alkarîmah), seperti ramah, adil, bijaksana, sabar, syukur, sopan, peduli, tanggap, tanggung jawab, mandiri, cinta kebersihan, cinta kedamaian, dan lain sebagainya sebagaimana yang melekat pada diri Rasulullah. Sebaliknya menghindarkan diri dari perilaku tercela (akhlak al-madzmûmah).

Lebih lanjut, Azzet mengemukakan bahwa di antara nilai karakter yang baik yang hendaknya dibangun dalam kepribadian anak adalah bisa bertanggung jawab, jujur, dapat dipercaya, menepati janji, ramah, peduli kepada orang lain, percaya diri, pekerja keras, bersemangat, tekun, tak mudah putus asa, bisa berpikir secara rasional dan kritis, kreatif dan inovatif, dinamis, bersahaja, rendah hati, tidak sombong, sabar, cinta ilmu dan kebenaran, rela berkorban, berhati-hati, bisa mengendalikan diri, tidak mudah terpengaruh oleh informasi yang buruk, mempunyai inisiatif, setia mengharga waktu, dan bisa bersikap adil.

Pertanyaannya adalah apakah nilai-nilai karakter terpuji tersebut di atas sudah diejawantahkan dalam kehidupan masyarakat Indonesia, khususnya dunia pendidikan? pertanyaan ini sesungguhnya menggugah kesadaran kita untuk melakukan refleksi terkait dengan konsistensi kita dalam beragama. 
Sejatinya agama tidak henti-hentinya mengingatkan kita melalui para alim, para ulama, para guru, dan elemen-elemen lainnya untuk membiasakan diri melakukan hal-hal yang baik. Dengan membiasakan diri secara terus-menerus akhirnya tertanam kuat dalam diri, itulah yang disebut karakter.

Karakter seseorang tidak bisa langsung tiba-tiba terbentuk menjadi baik, akan tetapi membutuhkan proses internalisasi dan pengalaman panjang serta penuh dengan tantangan. Sebagai contoh seseorang sudah berniat untuk menjadi orang baik, misalnya ingin berperilaku jujur, tiba-tiba ia kena musibah yang mengharuskan ia mengeluarkan uang dalam jumlah besar, kebetulan pada saat itu ia menjadi pemegang uang proyek. Dalam situasi dan kondisi seperti itu, tantangannya adalah apakah ia akan menggunakan uang tersebut untuk memenuhi keperluannya dengan cukup mengatakan bahwa uang proyek telah hilang? ataukah ia tetap jujur dengan tidak memanipulasi uang tersebut walaupun ia dalam keadaan sulit? persoalan seperti ini sering dihadapi oleh sebagian orang, maka beruntunglah orang-orang yang masih tetap memegang teguh nilainilai kejujuran tersebut.

Dalam pendidikan karakter, anak didik memang sengaja dibangun karakternya agar mempunyai nilai-nilai kebaikan sekaligus mempraktikkannya dalam kehidupan sehari-hari, baik 
itu kepada Tuhan Yang Maha Esa, dirinya sendiri, sesama manusia, lingkungan sekitar, bangsa, negara maupun hubungan internasional sebagai sesama penduduk dunia.

\section{b. Nilai Nilai Pendidikan Karakter dalam Surat Yusuf}

Setelah menelaah surat Yusuf secara keseluruhan maka sesuai dengan metodologi yang ditempuh, penulis mendapatkan beberapa nilai pendidikan karakter yaitu sebagai berikut:

\section{Religius}

Kata dasar dari religius adalah religi yang berasal dari bahasa asing religion sebagai bentuk dari kata benda yang berarti agama atau kepercayaan akan adanya sesuatu kekuatan kodrati di atas manusia. Sedangkan religius berasal dari kata religious yang berarti sifat religi yang melekat pada diri seseorang. Religius sebagai salah satu nilai karakter dideskripsikan oleh Suparlan sebagai sikap dan perilaku yang patuh dalam melaksanakan ajaran agama yang dianut, toleran terhadap pelaksanaan ibadah agama lain, dan hidup rukun dengan pemeluk agama lain. Karakter religius ini sangat dibutuhkan oleh siswa dalam menghadapi perubahan zaman dan degradasi moral, dalam hal ini 
siswa diharapkan mampu memiliki dan berprilaku dengan ukuran baik dan buruk yang di dasarkan pada ketentuan dan ketetapan agama. 16

Nilai karakter ini bisa kita temukan dengan memahami bahwa kepribadian Nabi Yusuf dan Ya'kub adalah pribadi orang yang taat kepada Allah dan mematuhi syariat agama. Itulah sebab utama mengapa mereka berdua dipilih sebagai Nabi pengembat risalah umat. Yusuf melihat mimpi ini di usia yang sangat belia yaitu 10 tahun, dan ini merupakan bentuk kemuliaan yang Allah anugrahkan kepada beliau. Mimpi yang seperti ini merupakan tanda kenabian yang Allah tunjukkan kepadanya. Namun karena Ya'kub mencium adanya potensi hasad dan kecemburuan dari saudara-saudara Yusuf, maka dia menasehatkan agar jangan diceritakan. Dan Ya'kub memberitahukan bahwa Yusuf kelak akan menjadi nabi pilihan Allah, terlihat pada ayat yang keenam yaitu, Allah telah memilihmu menjadi Nabi, mengajarkan engkau takwil mimpi, dan menyempurnakan nikmatnya kepadamu berupa harta, kekuasaan dan kehormatan. Menurut analisis penulis bahwa, Yusuf mendapatkan karunia tersebut adalah karena karakter religius yang melekat pada kepribadian beliau, 
berupa patuh dan taatnya dia kepada arahan bapaknya dalam masalah mimpi.

2. Nilai Tanggung Jawab

Sikap dan perilaku seseorang untuk melaksanakan tugas dan kewajibannya yang seharusnya dia lakukan, terhadap diri sendiri, masyarakat, lingkungan (alam sosial dan budaya), negara dan Tuhan Yang Maha Esa. Inilah yang penulis temukan dalam karakter ya'kub, karena kepeduliannya sebagai ayah untuk memberikan kasih sayang dan perlindungan terhadap anaknya demi kemashlahatan bersama. Seperti disebutkan dalam ayat 13

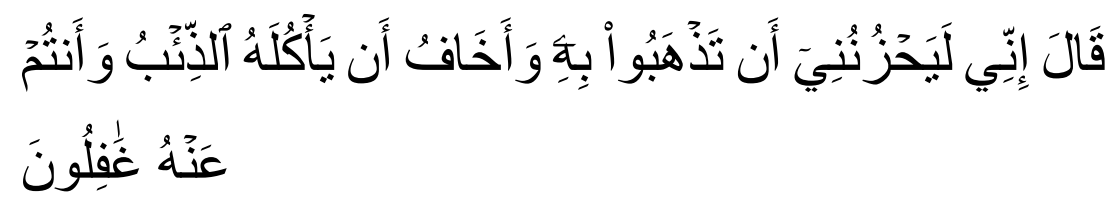

Berkata Ya'qub: "Sesungguhnya kepergian kamu bersama Yusuf amat menyedihkanku dan aku khawatir kalau-kalau dia dimakan serigala, sedang kamu lengah dari padanya"17

Ibnu katsir menyebutkan: jawaban Ya'kub terhadap permintaan anaknya untuk membawa serta Yusuf dalam keperluan mereka mengembala kambing ke padang pasir, 
sungguh aku sangat bersedih kalau kalian membawanya ikut serta, dan aku takut dia diterkam serigala. Sangat berat bagiku berpisah dengannya disaat kepergian kalian sampai kembali karena kecintaan yang besar terhadap Yusuf dan kebaikankebaikan yang terkumpul padanya serta kasihan karena beliau masih sangat belia.

3. Nilai Tanggung Jawab.

Walaupun sebelumnya sudah disebutkan tentang tanggung jawab, namun pada kelompok ini sosok figur yang memiliki tanggung jawab menurut penulis adalah raja mesir yang membeli Yusuf dari keterpurukan dan setelah dibuang oleh saudara-saudaranya. Disebutkan pada ayat 21-22.

Menurut penafsiran yang disebutkan oleh Ibn Katsir bahwa Allah mengabarkan tentang keadaan Yusuf as, bahwa Allah telah menetapkan bahwa orang yang membeli Yusuf adalah seseorang yang berasal dari mesir, dan dia adalah sosok yang memiliki kepedulian dan bertanggung jawab. Sehingga mereka memuliakan Yusuf dan menasehatkan istrinya untuk memeliharanya dan mengangkat sebagai anak dan bagian dari 
keluarga mereka. Dan yang membeli itu adalah seorang pembesar kaumnya di mesir yang bernama qithfir sebagaimana pendapat Ibnu Abbas. Sedangkan istrinya bernama zulaikha. Mereka mengasuh Yusuf sampai dewasa, banyak pendapat mengenai tafsiran "Walamma balagha asyuddah" ketika dia telah cukup dewasa, menurut penulis yaitu antara 25-40 tahun, sebagaimana yang disebutkan dalam tafsir Ibn Katsir tentang keanekaragaman pendapat mengenai berapa usia Yusuf kala itu. Namun yang menjadi fokus kita adalah kepedulian dan tanggungjawab keluarga itu dalam membesarkan dan mengayomi Yusuf kecil hingga beranjak dewasa, ini merupakan keutamaan yang Allah berikan kepada beliau di permukaan bumi ini.

\section{Nilai Kejujuran.}

Nilai kejujuran merupakan perilaku yang didasarkan pada upaya menjadikan dirinya sebagai orang yang dapat dipercaya dalam perkataan, tindakan dan pekerjaan. Hal itu ada pada pribadi Yusuf sebagai karakter yang melekat padanya. Selain karakter kejujuan ada juga pengembangan nilai karakter yang terdapat pada kelompok ayat ini yaitu 'iffah'. Beliau menjaga kehormatannya dan bersabar atas fitnah yang menimpanya. Sebagaimana terdapat pada ayat 23-29. 
Ini merupakan episode selanjutnya. Kata dan pada awal ayat di atas berfungsi sebagai perpindahan antara episode sebelumnya ke episode ini.

Sekian lama sudah Yusuf as. berada di kediaman orang Mesir itu. Dari hari ke hari, semakin jelas kehalusan budinya dan keluhuran akhlaknya. Kegagahan dan ketampanan wajahnya pun semakin menonjol. Kalau kita sepakat dengan Thabâthabâeci yang menjadikan ayat yang lalu sebagai awal episode, itu berarti kini Yusuf as. telah mencapai kematangan usia. Ia ketika itu belum mencapai tiga puluhan. Apapun yang terjadi, dan berapa pun usianya, yang jelas isteri orang Mesir itu-yang konon bernama Zalîkha, atau Zulaîkha, atau Râê̂l. Melihat dan memperhatikan dari hari ke hari pertumbuhan jasmani dan perkembangan jiwa Yusuf akhirnya muncullah rasa ketertarikan isteri Al-Aziz terhadap Yusuf as. tidak mustahil dia mengamati keindahan parasnya, kejernihan matanya, serta kehalusannya budinya. Dari hari ke hari perhatian itu semakin bertambah, sejalan dengan pertumbuhan Yusuf as. dan satu ketika entah bagaimana sang isteri sadar bahwa dia telah jatuh cinta kepada Yusuf as.

\section{Toleransi}


Yaitu sikap dan tindakan yang menghargai perbedaan agama, suku, etnis, pendapat, sikap dan tindakan orang lain yang berbeda dari dirinya. Karakter ini bisa tampak jelas kita perhatikan dari pembesar mesir ketiga memergoki istrinya bersama Yusuf, walaupun istrinya berusaha meyakinkan bahwa Yusuf yang salah, di sisi lain juga ia memberikan kesempatan kepada Yusuf untuk menyampaikan argumentasinya. Inilah bentuk toleransi yang dicontohkan oleh sosok raja mesir tersebut. Sebagaimana sisebutkan dalam ayat 25-29. Adanya silang pendapat itu tidak menjadikannya gegabah untuk memutuskan bahwa istrinya pasti benar, sehingga datanglah seorang saksi yang juga merupakan bagian dari anggota keluarga perempuan itu, lalu mengatakan "jika baju gamisnya koyak di bagian depan, maka perempuan itu benar, dan Yusuf termasuk orang yang berdusta. Dan jika baju gamisnya koyak dibagian belakang, maka perempuan itulah yang dusta. Dan ternyata setelah dilihat, Yusuf lah yang benar, karena ketika dilihat oleh raja, baju gamis Yusuf koyak dari bagian belakang. Lalu dia berkata sesungguhnya ini adalah tipu dayamu. Tipu dayamu benar-benar hebat. Dan dengan penuh kebijaksanaan beliau berucap sebagaimana pada ayat ke 29 berikut 
ini:

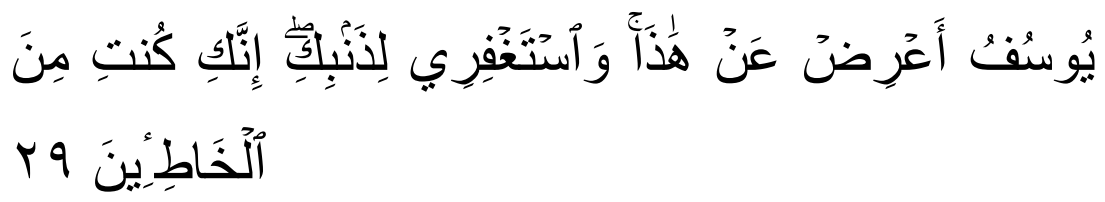

29. (Hai) Yusuf: "Berpalinglah dari ini, dan (kamu hai isteriku) mohon ampunlah atas dosamu itu, karena kamu sesungguhnya termasuk orang-orang yang berbuat salah"

Ini diantara dalil yang menunjukkan karakter raja yang menghargai pendapat orang lain, tidak gegabah dalam memutuskan suatu perkara, diantara makna dari nilai karakter toleransi menurut yang di analisis oleh penulis.

6. Rasa Ingin Tahu

Rasa ingin tahu merupakan sikap dan tindakan yang selalu berupaya untuk mengetahui lebih mendalam dan meluas dari sesuatu yang dipelajarinya, dilihat, dan didengar. Dan inilah yang bisa kita lihat dari sosok wanita-wanita pembesar di Mesir yang selalu berupaya mengetahui lebih meluas dan mendalam sesuatu yang didengarnya. Sebagaimana tertera pada ayat 30-32.

7. Cinta damai 
Yaitu sikap, perkataan, dan tindakan yang menyebabkan orang lain merasa senang dan amam atas kehadiran dirinya. Ini dapat kita lihat setelah Yusuf mengetahui makar dan tujuan dia dipanggil oleh Zulaikha karen sesuatu yang tidak baik lalu beliau memilih lebih baik penjara daripada terkesan mengganggu orang lain dan menyusahkan orang lain dengan kehadiran dirinya.

Kisah tentang ujian berikutnya yang dialami Yusuf as. ketika dipenjarakan oleh istri Al-'Aziz termuat dalam Q.S. Yusuf/12: 30-32 yang artinya sebagai berikut:

30. dan wanita-wanita di kota berkata: "Isteri Al Aziz menggoda bujangnya untuk menundukkan dirinya (kepadanya), Sesungguhnya cintanya kepada bujangnya itu adalah sangat mendalam. Sesungguhnya Kami memandangnya dalam kesesatan yang nyata." 31. Maka tatkala wanita itu (Zulaikha) mendengar cercaan mereka, diundangnyalah wanita-wanita itu dan disediakannya bagi mereka tempat duduk, dan diberikannya kepada masing-masing mereka sebuah pisau (untuk memotong jamuan), kemudian Dia berkata (kepada Yusuf): "Keluarlah (nampakkanlah dirimu) kepada mereka". Maka tatkala wanitawanita itu melihatnya, mereka kagum kepada (keelokan rupa) nya, dan mereka melukai (jari) tangannya dan berkata: "Maha 
sempurna Allah, ini bukanlah manusia. Sesungguhnya ini tidak lain hanyalah Malaikat yang mulia." 32. wanita itu berkata: "Itulah Dia orang yang kamu cela aku karena (tertarik) kepadanya, dan Sesungguhnya aku telah menggoda Dia untuk menundukkan dirinya (kepadaku) akan tetapi Dia menolak. dan Sesungguhnya jika Dia tidak mentaati apa yang aku perintahkan kepadanya, niscaya Dia akan dipenjarakan dan Dia akan Termasuk golongan orang-orang yang hina."

\section{Bersahabat/Komunikatif}

Sebagaimana yang telah penulis sebutkan pada bab sebelumnya bahwa komunikatif adalah tindakan yang memperlihatkan rasa senang berbicara, bergaul, dan bekerjasama dengan orang lain. Sikap yang mendorong seseorang untuk melakukan dan menghasilkan sesuatu yang berguna bagi masyarakat, dan mengakui serta menhgormati keberhasilan orang lain. Selain itu juga dapat berkomunikasi lisan dan tidak lisan dengan efektif juga merupakan kandungan arti dari nilai karakter komunikatif/bersahabat itu sendiri. Penulis mengamati dari teladan Nabi Ya'kub as yang memiliki karakter komunikatif terhadap anak-anaknya, bergaul, bekerjasama dan senantiasa menasehati mereka. Misalnya komunikasi beliau kepada Yusuf as 
agar tidak menceritakan mimpinya, nasehat kepada anak-anaknya agar menjaga Yusuf dan juga menjaga saudaranya bunyamin. Dan karakter ini juga ditemui penulis pada pribadi saudarasaudara Yusuf yang cukup komunikatif, ditilik dari beberapa negoisasi yang mereka lancarkan kepada ayah mereka.

Selanjutnya menurut analisis penulis bahwa karakter bersahabat dan komunikatif ini bisa terlihat dengan pembicaraan dan tanggapan serta dakwah yang beliau sampaikan dengan santun kepada 2 orang narapidana tersebut, beliau menggunakan analogi logika agar mereka bisa memahami dengan nalarnya, dengan demikian ini diantara kemuliaan yang Allah karuniakan kepada beliau. Sebagaimana disebutkan bagaimana karakter komunikatif yang terpancar dalam pribadi Yusuf pada ayat 3740.

9. Kerja keras

Kerja keras merupakan perilaku yang menunjukan upaya sungguh-sungguh dalam mengatasi berbagai hambatan guna menyelesaikan tugas (belajar/pekerjaan) dengan sebaik-baiknya. Selain itu, kerja keras juga merupakan perilaku yang menunjukan upaya sungguh-sungguh dalam mengatasi berbagai hambatan 
guna menyelesaikan tugas (belajar/pekerjaan) dengan sebaikbaiknya.

Dengan demikian, kerja keras adalah suatu sifat usaha yang dilakukan oleh seseorang dengan sungguh-sungguh dalam mengatasi berbagai hambatan untuk mencapai tujuan atau citacita sesuai dengan kemampuan masing-masing orang dan tidak mudah putus asa. Berdasarkan pengertian tentang kerja keras di atas dapat dipahami bahwa kesabaran merupakan bagian dari kerja keras. Kesabaran sangat dibutuhkan dalam kerja keras. Karena sifat kerja keras tidak akan muncul selama tidak ada kesabaran dalam diri seseorang. Selain itu, benih-benih kesabaran akan melahirkan sifat kerja keras. Semakin besar kesabaran seseorang maka akan semakin besar pula sifat kerja keras yang dimilikinya.

10. Rasa Ingin Tahu

Karakter ini sudah disebutkan sebelumnya, namun pada kelompok ayat ini beranjak dari munculnya mimpi raja. Raja menceritakan perihal mimpinya itu kepada para pejabat pemerintahannya, serta agamawan, dan orang yang cerdik dan pandai tentang takwil mimpi. Namun, setelah Raja selesai 
menceritakan mimpinya, mereka menjawab: Mimpi Tuan itu adalah mimpi-mimpi yang kosong. Tidak puas dengan itu, karena rasa ingin tahu yang bersarang pada pemikirannya. Kemudian salah seorang dari teman Yusuf ketika berada di dalam penjara teringat akan kemampuan Yusuf mentakwilkan mimpi mereka sebelumnya. Dia pun meminta Raja untuk mengutusnya kepada Yusuf agar dapat mentakwilkan mimpinya tersebut. Yusuf pun berhasil mentakwilkan mimpi sang Raja hingga dia dilepaskan dari penjara, ini sebagai bentuk balas budi yang dilakukan Raja kepada Yusuf.

\section{Menghargai prestasi}

Sikap dan tindakan yang mendorong dirinya untuk menghasilkan sesuatu yang berguna bagi masyarakat dan mengakui, serta menghormati keberhasilan orang lain. Ini yang tampak dari kepribadian Raja, ketika Yusuf telah berprestasi mentakwilkan mimpinya dan berusaha mengaktualisasikan takwil mimpi tersebut agar perekonomian masyarakat tetap aman dan terkendali, lalu bentuk penghormatan dan penghargaan yang dinerikan Raja kepada Yusuf sebagaimana disebutkan dalam ayat 54-57. Artinya : 
54. Dan raja berkata: "Bawalah Yusuf kepadaku, agar aku memilih dia sebagai orang yang rapat kepadaku". Maka tatkala raja telah bercakap-cakap dengan dia, dia berkata: "Sesungguhnya kamu (mulai) hari ini menjadi seorang yang berkedudukan tinggi lagi dipercayai pada sisi kami" 55. Berkata Yusuf: "Jadikanlah aku bendaharawan negara (Mesir); sesungguhnya aku adalah orang yang pandai menjaga, lagi berpengetahuan" 56. Dan demikianlah Kami memberi kedudukan kepada Yusuf di negeri Mesir; (dia berkuasa penuh) pergi menuju kemana saja ia kehendaki di bumi Mesir itu. Kami melimpahkan rahmat Kami kepada siapa yang Kami kehendaki dan Kami tidak menyia-nyiakan pahala orang-orang yang berbuat baik 57. Dan sesungguhnya pahala di akhirat itu lebih baik, bagi orang-orang yang beriman dan selalu bertakwa

\section{Nilai Tanggung Jawab}

Walaupun karakter ini sudah disebutkan sebelumnya, namun pada kelompok ayat ini afiliasi dari karakter tanggung jawab itu terlihat dari sikap Yusuf yang berusaha menyiapkan dan menyimpan hasil panen selama tujuh tahun berturut-turut demi perbekalan untuk menghadapi musim paceklik di tahun-tahun berikutnya. Pada ayat berikutnya ini juga terlihat karakter 
tanggung jawab yang ada pada pribadi Ya'kub terhadap keselamatan anak-anaknya, karena beliau sangat perhatian dan mencintai anak-anaknya. Dan mereka juga mematuhi arahan dari ayahnya. Sebagaimana yang akan dijelaskan pada ayat 65-68.

\section{Nilai Kepedulian sosial}

Pada kelompok ayat ini juga tercermin karakter kepedulian sosial dri pribadi Yusuf, berkat wahyu yang Allah karuniakan kepada beliau untuk mengetahui takwil mimipi dan kebenaran dari takwil itu, sehingga muncullah kepedulian sosial dari pribadi Yusuf. Manusia pada dasarnya merupakan makhluk sosial yang tidak dapat hidup sendiri dan membutuhkan orang lain. Manusia dalam hidup bermasyarakat haruslah saling menghormati, mengasihi, dan peduli terhadap berbagai macam keadaan disekitarnya. Kepedulian merupakan sikap memperhatikan sesuatu. Dengan demikian, kepedulian sosial merupakan sikap memperhatikan atau menghiraukan urusan orang lain (sesama anggota masyarakat). Kepedulian yang dimaksud bukanlah untuk terlalu mencampuri urusan orang lain, tetapi lebih kepada membantu menyelesaikan permasalahan yang dihadapi orang lain dengan tujuan kebaikan dan perdamaian. Mengenai bentuk kepedulian ini, disebutkan dalam ayat 58-62. 
14. Semangat kebangsaan

Karakter semangat kebangsaan dapat kita dapati dan kita lihat dalam diri para pahlawan yang telah berjuang merebut kemerdekaan negara Republik Indonesia tanpa mengharapkan balasan maupun pujian dari orang lain. Bahkan, Kita sering menyaksikan orang-orang yang dengan tulus mengorbankan segalanya baik dana maupun tenaganya untuk memberikan pendidikan dan pelayanan kesehatan untuk sudara-saudara kita yang berada dipelosok-pelosok maupun yang berada di perbatasan Indonesia tercinta.

Hal ini pula yang tercermin dalam diri Yusuf as. yang memberikan pelayanan secara merata kepada para rakyat Mesir tanpa mengharap pujian maupun balasan dari Raja dan rakyat Mesir. Diantara hal yang sangat penting pada pengembangan karakter ini juga adalah nila keadilan. Nilai keadilan dalam surat ini terdapat pada ayat ke-55 yang berbunyi sebagai berikut:

berkata Yusuf: "Jadikanlah aku bendaharawan negara (Mesir); Sesungguhnya aku adalah orang yang pandai menjaga, lagi berpengetahuan".

15. Nilai kejujuran 
Sebenarnya nilai kejujuran ini sudah kita sebutkan dan sudah ada pada ayat sebelumnya, namun pada kelompok ayat ini menjelaskan tentang tulus dan jujurnya niata saudara Yusuf untuk mendapatkan bahan makanan dan tidak terbetik sedikitpun untuk melakukan tipu muslihat.

16. Religius

Perasaan religius ialah perasaan berkaitan dengan Tuhan atau Yang Maha Kuasa, antara lain takjub, kagum, percaya, yakin keimanan, tawakal, pasrah diri, rendah hati ketergantungan pada Ilahi,merasa diri sangat kecil, kesadaran akan dosa dan lain-lain.

Definisi lain diungkap, Glock dan Strak merumuskan relegiusitas sebagai komitmen religius (yang berhubungan dengan agama atau keyakinan iman) yang dapat dilihat melalui aktivitas atau perilaku individu yang bersangkutan dengan agama atau keyakinan iman yang dianut.

Religiusitas seringkali diidentikkan dengan keberagamaan. Relegiusitas diartikan sebagai seberapa jauh pengetahuan. Seberapa kokoh kenyakinan. Seberapa pelaksanaa ibadah dan kaidah dan seberapa dalam penghayatan atas agama yang dianutnya. Inilah yang diwujudkan dalam perilaku sehari- 
hari. Sedangkan Ahyadi mendefinisikan sikap religiusitas sebagai tanggapan pengamatan, pemikiran, perasaan dan sikap ketaatan yang diwarnai oleh rasa keagamaan.Dan bentuk karakter religius ini terlihat dari jawaban Ya'kub ketika menghadapi situasi dimana beliau kehilangan dua anak yang amat dicintai. Sebagaimana yang ditegaskan pada ayat ke 83 .

\section{Cinta damai}

Cinta damai ini bisa dipahami apabila kepribadian sesorang memiliki sikap, perkataan, dan tindakan yang menyebabkan orang lain merasa senang dan aman atas kehadiran dirinya. Dan inilah yang terdapat dalam kepribadian Ya'kub ketika memafkan kesalahan anak-naknya yang telah berdusta, kemudian memohonkan ampunan kepada Allah untuk mereka. Dan sikap ini juga terdapat dalam diri Yusuf, dengan penuh rasa suka dan lapang dada beliau menyambut kedatangan keluarganya, yang membuat mereka merasa damai.

Pada ayat ini diceritakan tenang kelalaian mayoritas manusia dalam memikirkan tanda-tanda kebesaran Allah swt dan bukti-bukti kekuasaan Allah melauli makhluk-maklhluk yang diciptakannya di langit maupun di bumi, yaitu bintang-bintang 
yang cemerlang sinarnya, yang tetap dan beredar serta gugusangugusan bintang lainnya. Semuanya itu tunduk pada kekuasaan Allah. Berdasarkan uraian dalam tiap bab, dapat kita pahami bahwa krisis moralitas dan karakter utama bangsa ini perlu diperbaiki dengan cara mengoptimalkan nilai-nilai pendidikan karakter tersebut (Romadhon, dkk, 2017).

\section{c. Nilai Pendidikan Karakter dalam Q.S. Al-An'am ayat 151-} 153

1) Surat Al-an'am ayat 151.

ata

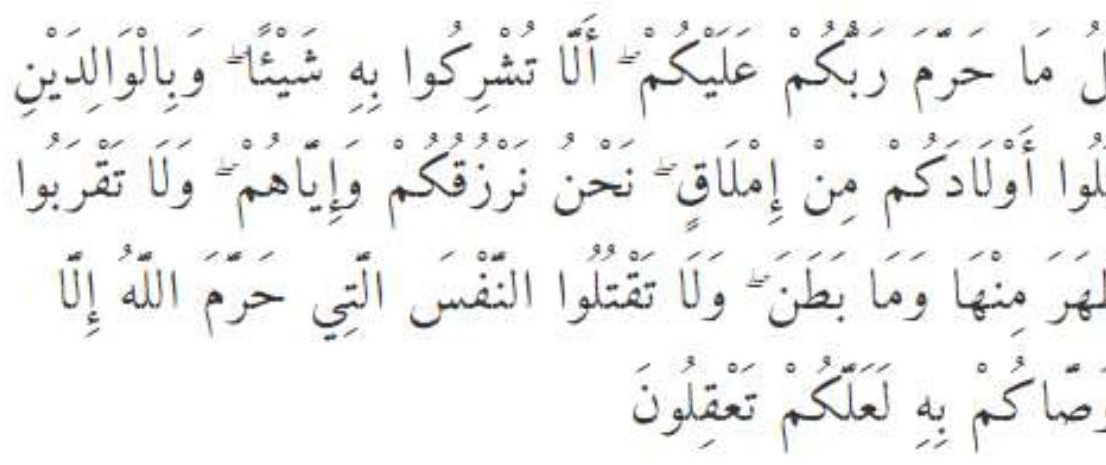


mempersekutukan sesuatu dengan Dia, berbuat baiklah terhadap kedua orang ibu bapa, dan janganlah kamu membunuh anakanak kamu karena takut kemiskinan. Kami akan member rezeki kepadamu dan kepada mereka; dan janganlah kamu mendekati perbuatan-perbuatan yang keji, baik yang nampak di antaranya maupun yang tersembunyi, dan janganlah kamu membunuh jiwa yang diharamkan Allah (membunuhnya) melainkan dengan sesuatu (sebab) yang benar".

Demikian itu yang diperintahkan oleh Tuhanmu kepadamu supaya kamu memahami (Nya).

Dalam ayat 151 ini terdapat nilai-nilai karakter yaitu, nilai religius, dimana dalam hal ini ada larangan untuk tidak menyekutukan Allah dalam arti bahwa dalam hal ini lebih kepada menjaga ketauhidan seseorang agar tidak terjerumus kepada jalan yang salah. Terdapat nilai akan cinta damai yang di tunjukan oleh sikap atau tingkah laku agar berbuat baik kepada kedua orang tua, kemudian larangan untuk membunuh anak karena takut kemiskinan, hal ini merupakan salah satu nilai kepedulian sosial dimana adanya sikap saling menghargai akan hak setiap manusia, tidak bersikap semena mena akan orang lain, serta harus mengetahui akan apa yang Allah perintahkan dan apa yang dilarang-Nya. 
2) Surat Al-an'am ayat 152

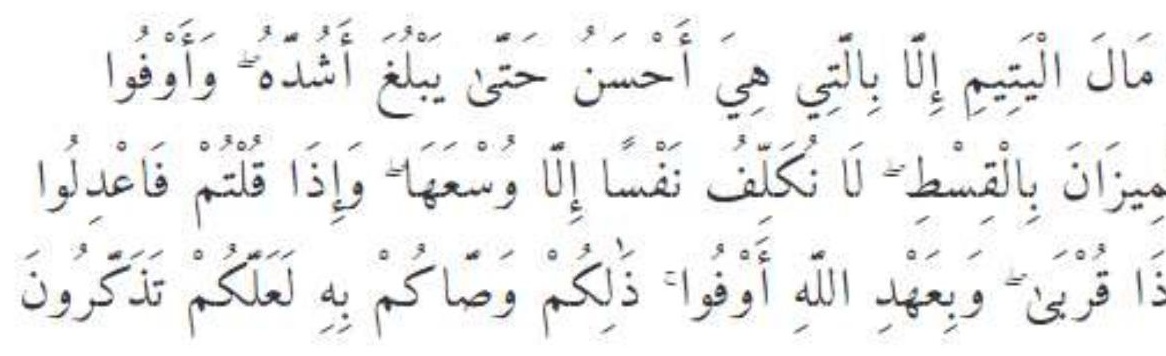

"Dan janganlah kamu dekati harta anak yatim, kecuali dengan cara yang lebih bermanfaat, hingga sampai ia dewasa. Dan sempurnakanlah takaran dan timbangan dengan adil. Kami tidak memikulkan beban kepada seseorang melainkan sekedar kesanggupannya. Dan apabila kamu berkata, maka hendaklah kamu berlaku adil kendati pun dia adalah kerabat (ти), dan penuhilah janji Allah. Yang demikian itu diperintahkan Allah kepadamu agar kamu ingat". (Q.S. al-An'am, 6: 152).

Dalam ayat 152 terdapat nilai peduli sosial yang ditunjukkan dengan adanya larangan mendekati harta anak yatim, kecuali dengan cara yang lebih bermanfaat, dalam arti tidak diperbolehkan kepada siapapun akan harta anak yatim itu sendiri apalagi sampai dipergunakan untuk kepentingan pribadi yang tentunya itu tidak boleh dilakukan. 
Larangan yang menyangkut harta dimulai dengan larangan mendekati harta kaum lemah, yakni anak-anak yatim. Ini sangat wajar karena mereka tidak dapat melindungi diri dari penganiayaan akibat kelemahannya. Dan karena itu pula, larangan ini tidak sekedar melarang memakan atau menggunakan, tetapi juga mendekati.

Dengan cara menjaga harta anak yatim maka dengan tidak kita sadari bahwa itu merupakan sesuatu hal yang mencerminkan bahwa kita memiliki sikap peduli sosial terhadap sesama dan tentunya itu merupakan sesuatu yang baik. Adapun diperbolehkan menggunakan akan harta anak yatim itu dengan cara yang baik dan tentunya bermanfaat dan maslahat bagi orang lain.

Dalam ayat 152 terdapat nilai kejujuan serta keadilan dengan adanya rasa tanggungjawab atas apa yang menjadi tnggungjawabnya baik itu dilakukan kepada orang lain ataupun terhadap dirinya sendiri, jadi tidak adanya diskriminasi antara dirinya dan orang lain dalam hal apapun yang sesuai dengan syariat Islam.

Ini dikemukakan untuk mengingatkan bahwa memang dalam kehidupan sehari-hari tidak mudah mengukur, apabila menimbang, yang benar-benar mencapai kadar adil yang pasti, 
tetapi kendati demikian, penimbang dan penakar hendaknya berhati-hati senantiasa melakukan penimbangan dan penakaran itu semampu mungkin.

3) Surat Al-an'am ayat 153

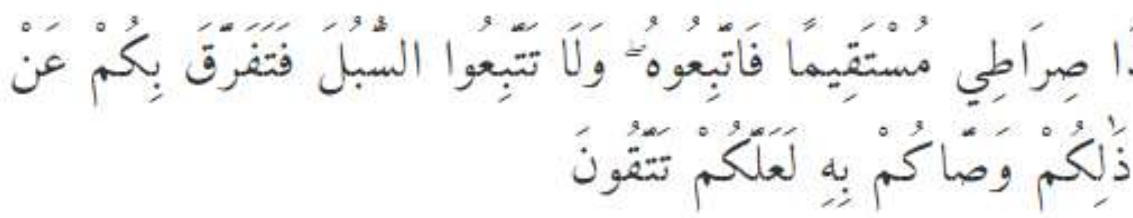

"Dan bahwa (yang Kami perintahkan) ini adalah jalan-Ku yang lurus, maka ikutilah dia; dan janganlah kamu mengikuti jalanjalan (yang lain), karena jalan-jalan itu mencerai-beraikan kamu dari jalan-Nya. Yang demikian itu diperintahkan Allah kepadamu agar kamu bertakwa.(Q.S.al-An'am ayat 153).

Dalam ayat terakhir yaitu ayat 153 terdapat nilai karakter yaitu nilai rasa ingin tahu, dimana dengan cara kita mencari tahu bagaimana mengikuti jalan yang benar sehingga tidak mengikuti jalan yang salah yaitu dengan cara melakukan perintah Allah 
yang tentu baik bagi makhluk-Nya dan tentunya hal tersebut ada pada Ridha-Nya (Ratna, dkk, 2017)

\section{d. Petunjuk Al Qur'an Dan Hadits}

Al Qur'an dan Hadits dengan jelas telah menjadi petunjuk bagi umat manusia pada umumnya dan khususnya bagi para pendidik dalam rangka penanaman pendidikan karakter. Sebagai agama yang lengkap, Islam sudah memiliki aturan yang jelas tentang pendidikan karakter. Di dalam al-Quran akan ditemukan banyak sekali pokok-pokok pembicaraan tentang akhlak atau karakter ini. Seperti perintah untuk berbuat baik (ihsan), dan kebajikan (al-birr), menepati janji (al-wafa), sabar, jujur, takut kepada Allah SWT, bersedekah di jalan Allah, berbuat adil, pemaaf dalam banyak ayat di dalam al-Quran. Kesemuanya itu merupakan prinsip-prinsip dan nilai karakter mulia yang harus dimiliki oleh setiap anak didik.

Implementasi pendidikan karakter dalam Islam, tersimpul dalam karakter pribadi Rasulullah SAW. Dalam pribadi Rasul, tertanam nilai-nilai akhlak yang mulia dan agung.

Dalam surah al-Qalam ayat 4 dijelaskan: 


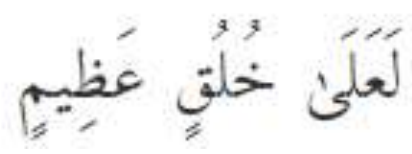

"Dan sesungguhnya kamu benar-benar berbudi pekerti yang agung".

Sementara itu, dalam surat al-Ahzab ayat 21 dijelaskan:

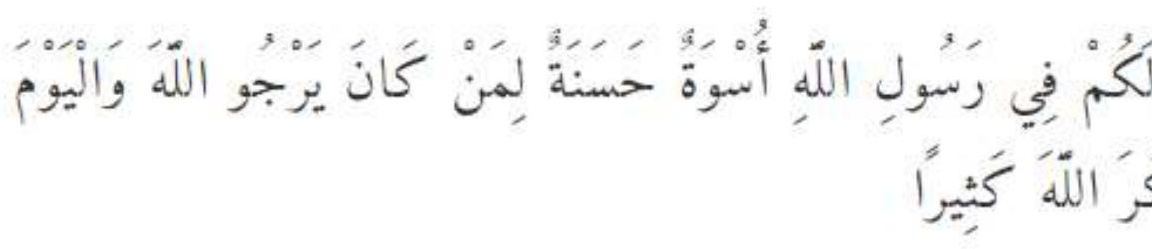

"Sesungguhnya Telah ada pada (diri) Rasulullah itu suri teladan yang baik bagimu (yaitu) bagi orang yang mengharap (rahmat) Allah dan (kedatangan) hari kiamat dan dia banyak menyebut Allah".

Dengan demikian, sesungguhnya Rasulullah SAW adalah teladan bagi manusia yang mengajarkan serta menanamkan nilainilai karakter yang mulia kepada umatnya. Sebaik-baik manusia adalah yang baik karakter atau akhlaknya dan manusia yang sempurna adalah yang memiliki akhlak al-karimah, karena ia merupakan cerminan iman yang sempurna. Karenanya, sebaik- 
baik teladan pendidikan karakter, adalah teladan Rasulullah SAW.

Dalam Islam, karakter atau akhlak mempunyai kedudukan penting dan dianggap mempunyai fungsi yang vital dalam memandu kehidupan masyarakat. Sebagaimana firman Allah SWT di dalam Al-Qur'an surat An-Nahl ayat 90 sebagai berikut:

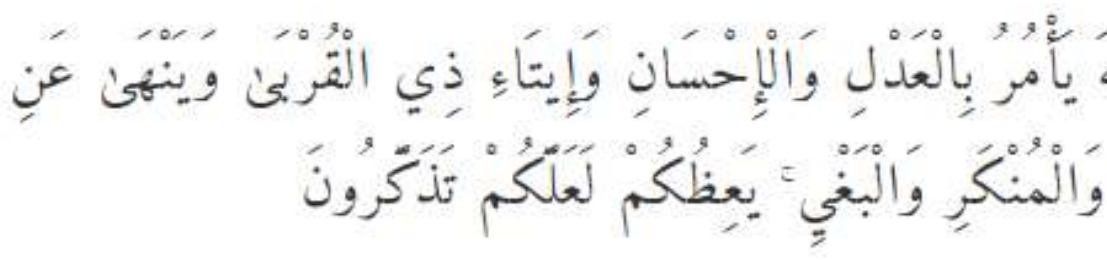

"Sesungguhnya Allah menyuruh (kamu) berlaku adil dan berbuat kebajikan, memberi kepada kaum kerabat, dan Allah melarang dari perbuatan keji, kemungkaran dan permusuhan. dia memberi pengajaran kepadamu agar kamu dapat mengambil pelajaran".

Ayat di atas menjelaskan tentang perintah Allah yang menyuruh manusia agar berbuat adil, yaitu menunaikan kadar kewajiban berbuat baik dan terbaik, berbuat kasih sayang pada ciptaan-Nya dengan bersilaturrahmi pada mereka serta menjauhkan diri dari berbagai bentuk perbuatan buruk yang menyakiti sesama dan merugikan orang lain. 
Melalui ayat di atas dapat dipahami bahwa ajaran Islam serta pendidikan karakter mulia yang harus diteladani agar manusia yang hidup sesuai denga tuntunan syari'at, yang bertujuan untuk kemaslahatan serta kebahagiaan umat manusia. Islam merupakan agama yang sempurna, sehingga tiap ajaran yang ada dalam Islam memiliki dasar pemikiran, begitu pula dengan pendidikan karakter. Adapun yang menjadi dasar pendidikan karakter adalah al-Qur'an dan al-Hadits, dengan kata lain dasar-dasar yang lain senantiasa dikembalikan kepada alQur'an dan al-Hadits.

Kemudian, ada sebuah ayat Al-qur'an lagi yang menjadi dasar pendidikan karakter adalah berfirman di dalam Al Quran surah al-Isra' ayat 23-24 yang berbunyi:

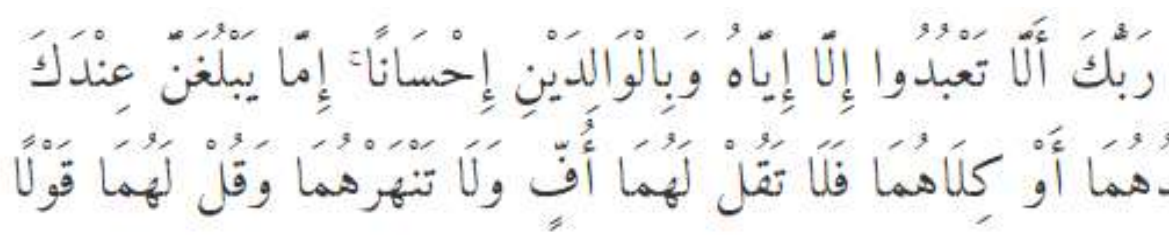

"Dan Tuhanmu telah memerintahkan supaya kamu jangan menyembah selain Dia dan hendaklah kamu berbuat baik pada ibu bapakmu dengan sebaik-baiknya. Jika salah seorang di 
antara keduanya atau kedua-duanya sampai berumur lanjut dalam pemeliharaanmu, maka sekali-kali janganlah kamu mengatakan kepada keduanya perkataan "ah" dan janganlah kamu membentak mereka dan ucapkanlah kepada mereka perkataan yang mulia".

Ayat ini merupakan salah satu ayat yang memuat materi pendidikan yang harus ditanamkan dalam lingkungan keluarga. Perintah Allah yang termaktub di dalam ayat ini, mencakup bidang pendidikan karakter (akhlak) berupa Aqidah, ibadah dan akhlak yang harus terbina bagi seorang anak. Demikian juga peran serta orang tua dalam memberikan bimbingan moral dan keluhuran dalam upaya membentuk karakter anak yang berkualitas.

Sementara itu jika kita lihat dari petunjuk hadits, ada beberapa hadits yang bisa kita jadikan dasar bagi pembentukan karakter anak :

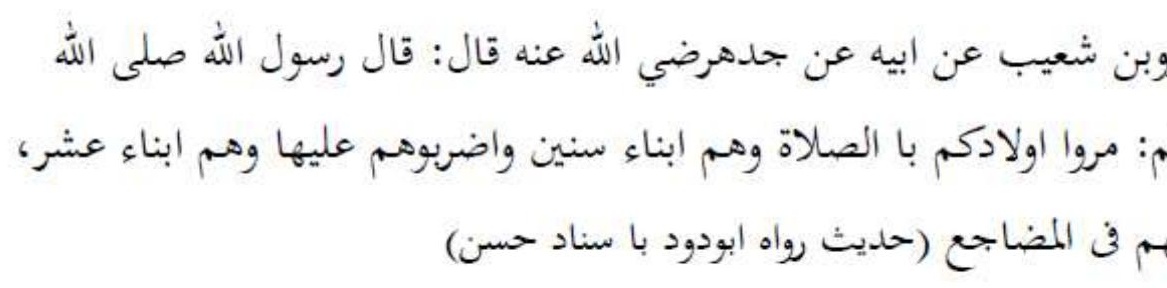


“Dari Amru bin Syu'aib dari bapaknya dari kakeknya RA berkata: Rasulullah SAW bersabda : perintahkan anak-anakmu untuk melaksanakan shalat, ketika mereka sampai di usia 7 tahun, kemudian pukul mereka karena meninggalkan shalat jika telah sampai usia 10 tahun dan pisahkan diantara mereka di tempat tidurnya". (H.R. Abu Daud)

Hadits ini mengisyaratkan bahwa pembentukan karakter anak hendaklah melalui tahapan-tahapan yang dimulai ketika anak masih masa kanak-kanak, bahkan ketika anak masih berbentuk janin di dalam kandungan.

Kemudian yang menjadi tujuan akhir dari pendidikan karakter adalah membentuk pribadi anak yang memiliki akhlaq mulia sebagai mana akhlaq Rasulullah SAW. Sebab dengan berhasilnya pendidikan karakter yang berkiblat pada akhlaq Rasul, maka untuk seterusnya anak didik akan menjadi generasi membanggakan. Sebagaimana dalam hadits Nabi yang diriwayatkan oleh Bukhori dan Muslim :

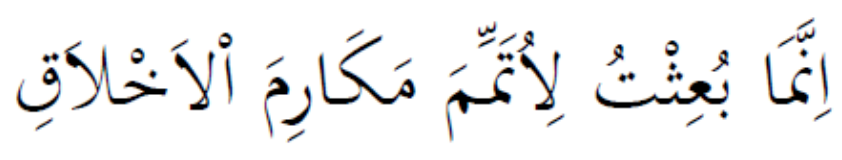

"Aku (Muhammad) diutus ke muka bumi ini semata-mata untuk menyempurnakan akhlak." 
Melalui berbagai metode internalisasi pendidikan karakter dan petunjuk-petunjuk dari Al Qur'an dan Hadits tersebut kecil sekali kemungkinan munculnya karakter anak bermasalah, seperti: susah diatur dan susah diajak kerja sama, kurang terbuka kepada orang tua, menanggapi negative terhadap semua persoalan, menarik diri dari pergaulan, menolak kenyataan yang terjadi dan menganggap dirinya dan hidupnya sebagai palawak (bahan tertawaan). Justru yang muncul adalah sebaliknya, manusia yang berbudi pekerti luhur, peka terhadap lingkungan dan mampu membawa perubahan positif bagi umat manusia.

\section{B. Pancasila}

Bagi bangsa Indonesia, Pancasila merupakan dasar negara, pandangan hidup bangsa kepribadian bangsa, jiwa bangsa, asas kehidupan bermasyarakat, berbangsa, dan bernegara, serta merupakan jati diri bangsa. Karakter yang berlandaskan falsafah Pancasila berarti setiap aspek karakter harus dijiwai oleh kelima sila Pancasila secara utuh dan komprehensif.

Berikut adalah nilai-nilai karakter yang bersumber dari Pancasila yang dipaparkan oleh Samani dan Hariyanto (2011: 2224). 
1) Bangsa yang ber-Ketuhanan Yang Maha Esa

Nilai Karakter:

\section{Karakter terhadap Tuhan YME}
a) taat menjalankan kewajiban agama masing-masing;
b) sabar atas segala ketentuan-Nya;
c) ikhlas dalam beramal;
d) tawakal;
e) senantiasa bersyukur

\section{Karakter antar manusia}

a) saling hormat menghormati;

b) bekerja sama;

c) berkebebasan menjalankan ibadah sesuai ajaran agamanya;

d) tidak memaksakan agama dan kepercayaannya terhadap orang lain;

e) tidak melecehkan kepercayaan agama seseorang

2) Bangsa yang menjunjung Kemanusiaan Yang Adil dan Beradab

Nilai Karakter:

a) Hormat menghormati antar warga dan bangsa lain;

b) Mengakui kesamaan derajat, hak dan kewajiban;

c) Saling mengasihi;

d) Tenggang rasa; 
e) Peduli;

f) Tidak semena-mena terhadap orang lain;

g) Membela kebenaran dan keadilan.

3) Bangsa yang mengedepankan Persatuan dan Kesatuan Indonesia.

Nilai Karakter:

a) Menempatkan persatuan, kesatuan, kepentingan, dan keselamatan bangsa di atas kepentingan pribadi atau golongan;

b) Bergotong royong;

c) Rela berkorban untuk kepentingan bangsa dan negara;

d) Cinta tanah air;

e) Bangga berbangsa Indonesia;

f) Menjunjung tinggi Bahasa Indonesia.

4) Bangsa yang demokratis dan menjunjung tinggi Hukum dan Hak Asasi Manusia.

Nilai Karakter:

a) Menghargai pendapat orang lain;

b) Tidak memaksakan kehendak;

c) Bersahaja dan tenggang rasa;

d) Mengutamakan kepentingan rakyat dan Negara;

e) Musyawarah untuk mufakat;

f) Menggunakan akal sehat dan nurani luhur dalam musyawarah 
5) Bangsa yang mengedepankan Keadilan dan Kesejahteraan. Nilai Karakter:

a) Menjaga kebersamaan, kekeluargaan, dan gotong royong;

b) Menjaga harmonisasi antara hak dan kewajiban;

c) Menghormati hak-hak orang lain;

d) Menolong orang lain;

e) Tidak boros;

f) Tidak bergaya hidup mewah;

g) Bekerja keras;

h) Menghargai karya orang lain.

Pemaparan nilai-nilai karakter yang terkandung dalam Pancasila di atas menunjukkan betapa besarnya harapan dan citacita para perumus dan pencetusnya terhadap kelangsungan generasi bangsa Indonesia. Nilai-nilai tersebut sarat akan nilainilai luhur yang layak dipertahankan sebagai budaya bangsa dan cerminan wajah Indonesia.

\section{a. Pancasila Sebagai Karakter Bangsa Indonesia}

Maswardi Rauf (2008: 88) menegaskan, karakter bangsa adalah "sifat yang melekat pada bangsa secara keseluruhan yang terlihat dari pola pikir dan tingkah laku yaitu kultur/budaya atau nilai yang dianut oleh warga masyarakat untuk menjadi pedoman 
dalam bertingkah laku". Berdasarkan pendapat di atas karakter bangsa dapat terbangun melalui budaya yang ada di masyarakat. Sedangkan budaya-budaya tersebut di kristalisasikan dan melahirkan suatu pandangan hidup bersama yang kita kenal dengan Pancasila. Sehingga keberadaan nilai-nilai Pancasila perlu terus dibina, dikembangkan dan dilestarikan. Pembinaan karakter bangsa dengan nilai-nilai Pancasila bertujuan agar bangsa Indonesia mampu bersikap dan bertingkah laku dengan sepatutnya sehingga mampu mengantar bangsa menuju kesuksesan hidup sesuai dengan cita-cita bangsa. Kesuksesan hidup suatu bangsa tergantung bagaimana bangsa tersebut dapat membawa diri sesuai dengan cita-cita yang didambakannya, serta mampu untuk mengantisipasi secara tepat tantangan zaman. Dengan demikian sumber karakter adalah belief system yang telah terpatri dalam sanubari bangsa, serta tantangan dari luar sehingga membentuk sikap dan perilaku yang akan mengantar bangsa mencapai kehidupan yang sukses. Bagi bangsa Indonesia belief system ini tiada lain adalah Pancasila yang di dalamnya terdapat konsep, prinsip dan nilai yang merupakan faktor endogen bangsa Indonesia dalam membentuk karakternya.

Desain Induk Pembangunan Karakter Bangsa (2010:7) menyebutkan bahwa karakter bangsa merupakan "kualitas 
perilaku kolektif kebangsaan yang unik-baik tercermin dalam kesadaran, pemahaman, rasa, karsa, dan perilaku berbangsa dan bernegara dari hasil olah pikir, olah hati, olah rasa dan karsa, serta olah raga seseorang atau sekelompok orang". Sehingga individu yang telah dijiwai oleh silasila Pancasila melaksanakan nilai-nilai berikut :

1. Karakter yang bersumber dari olah hati, antara lain beriman dan bertakwa, jujur, amanah, adil, tertib, taat aturan, bertanggung jawab, berempati, berani, mengambil resiko, pantang menyerah, rela berkorban, dan berjiwa patriotik;

2. Karakter yang bersumber dari olah piker antara lain cerdas, kritis, kreatif, inovatif, ingin tahu, produktif, berorientasi iptek dan reflektif;

3. Karakter yang bersumber dari olah raga antara lain: bersih, sehat, sportif, tangguh, andal, berdaya tahan, bersahabat, kooperatif, determinatif, kompetitif, ceria, dan gigih;

4. Karakter yang bersumber dari olah rasa dan karsa antara lain, kemanusiaan, saling menghargai, gotong royong, kebersamaan, ramah, hormat, toleran, nasionalis, peduli, kosmopolit, mengutamakan kepentingan umum, cinta tanah air, bangga mengunakan bahasa dan produk Indonesia, dinamis, kerja keras, 
dan beretos kerja (Desain Induk Pembangunan Karakter Bangsa, 2010:22).

Dengan demikian, berdasarkan pendapat-pendapat di atas, karakter bangsa dimaknai ciri-ciri kepribadian yang relative tetap, gaya hidup yang khas, cara pikir, bersikap, dan berperilaku yang sesuai nilai nilai luhur yang bersumber dari budaya bangsa Indonesia yang dijiwai nilai-nilai Pancasila

\section{b. Pancasila sebagai Sumber Nilai}

Pancasila merupakan ideologi, dasar negara, dan falsafah negara yang harus dipertahankan dan terus dihidupkan demi keutuhan Negara Kesatuan Republik Indonesia (NKRI). Apalagi dewasa ini pemahaman akan nilai-nilai Pancasila dan nasionalisme generasi muda semakin menurun. Oleh karena itu, penting dilakukannya revitalisasi nilainilai Pancasila bagi elemen masyaraka pada umumnya

dan generasi muda pada khususnya.

Indonesia merupakan negara yang beragam, kehidupan masyarakatnya diwarnai oleh berbagai macam suku bangsa, adatistiadat, hingga berbagai macam agama dan aliran kepercayaan. Dengan kondisi sosiokultur yang heterogen atau plural tersebut dibutuhkan idiologi yang universal, tetapi dapat mengayomi 
seluruh bangsa. Ideologi itulah yang disebut Pancasila. Bapak Pendidikan Nasional Republik Indonesia, Ki Hadjar Dewantara pernah menegaskan: “...Pengajaran harusbersifat kebangsaan, kalau pengajaran bagi anak-anak tak mungkin mempunyai rasa cinta bangsa dan makin lama terpisah dari bangsanya, kemudian barangkali menjadi lawan kita..."

Pancasila adalah dasar negara. Pancasila bukan wahana tetapi ruh yang harus tetap hidup karena tanpa Pancasila maka Indonesia tidak ada. Di atas Pancasila sebagai dasar negara itu, berdirilah pilar-pilar negara. Ada empat pilar yang ditegakkan di atas dasar negara yaitu: 1) Proklamasi Kemerdekaan (sebagai pesan eksistensial tertinggi), 2) UUD 1945, 3) NKRI, 4) Bhinneka Tunggal Ika. Tanpa dasar maka pilar-pilar akan mengambang. Pancasila sebagai dasar memberi ruh dan warna pada pilar-pilar yang ditegakkan di atasnya (Sri Edi, 2014:29).

Pembangunan karakter bangsa sudah menjadi harga mati pada masa-masa sekarang ini. Perilaku-perilaku menyimpang yang telah membudaya hanya dapat diberantas secara tuntas dengan mengubah pola pikir dan karakter seseorang. Terkadang kita sulit untuk menentukan parameter yang sesuai terlebih-lebih dengan kemajemukan bangsa Indonesia yang terdiri dari bermacamma cam etnis, agama, budaya, dan 
sebagainya.Disinilah kita semestinya kembali kepada nilai-nilai luhur bangsa yang terkandung dalam Pancasila. Pada hakikatnya pendidikan Pancasila adalah upaya sadar diri suatu masyarakat dan pemerintah suatu negara untuk menjamin kelangsungan hidup dan kehidupan generasi penerusnya, selaku warga masyarakat, bangsa dan negara secara berguna (berkaitan dengan kemampuan spiritual) dan bermakna (berkaitan dengan kemampuan kognitif dan psikomotorik) serta mampu mengantisipasi hari depan mereka yang senantiasa berubah dan selalu terkait dengan konteks dinamika budaya, bangsa, negara, dan hubungan internasionalnya. Berdasarkan UU no. 20 tahun 2003 tentang sistem pendidikan nasional, pasal 2 menyatakan bahwa "pendidikan nasional berdasarkan Pancasila dan UUD 1945".Undang-Undang Dasar 1945 mengamanatkan "Pemerintah mengusahakan dan menyelenggarakan satu sistem pendidikan nasional", dapat diartikan bahwa kurikulum pendidikan nasionalseharusnya adalah untuk memperkokoh sikap cinta tanah air atau nasionalisme, dengan kata lain kurikulum pendidikan nasional seharusnya membudayakan mindset ketunggalikaan di tengah realita kemajemukan atau kebhinekaan Indonesia. 
Pancasila secara alami lahir dari kepribadian bangsa Indonesia itu sendiri. Keberagaman di Indonesia seperti keragaman suku, agama, bahasa daerah, pulau, adat istiadat, warna kulit, kebiasaan budaya yang berbeda satu sama lain dapat dipersatukan dengan Pancasila. Nilai-nilai yang terkandung dalam tiap butir sila Pancasila merupakan cerminan jati diri bangsa yang sudah melekat pada tiap sanubari warga Negara Kesatuan Republik Indonesia. Pancasila memiliki lima buah sila yang memiliki makna yang mendalam sesuai dengan kepribadian bangsa Indonesia.

\section{c. Nilai-nilai dalam Pancasila}

Di dalam Dictionary of sociology nilai adalah kemampuan yang dipercaya yang ada pada sesuatu benda untuk memuaskan manusia. Jadi, nilai itu pada hakikatnya adalah sifat atau kualitas yang melakat pada suatu objek, bukan objek itu sendiri. Sesuatu itu mengandung nilai artinya ada sifat atau kualitas yang melekat pada sesuatu itu. Sebagai suatu dasar filsafat negara maka silasila Pancasila merupakan suatu nilai. Oleh karena itu, sila-sila Pancasila itu pada hakikatnya merupakan suatu kesatuan, meskipun antara sila yang satu dengan sila yang berbeda, tetapi 
kesemuanya merupakan kesatuan yang sistematis. Berikut penjelasan sila-sila dalam Pancasila.

1) Sila Ketuhanan Yang Maha Esa. Sila ini nilai-nilainya meliputi dan menjiwai keempat sila lainnya. Dalam sila Ketuhanan Yang Maha Esa terkandung nilai bahwa negara yang didirikan adalah sebagai penjawantahan tujuan manusia sebagai mahkluk Tuhan Yang Maha Esa. Oleh karena itu, segala hal yang berkaitan dengan pelaksanaan dan penyelenggaran negara, hukum dan peraturan perundang-undangan negara, kebebasan dan HAM harus dijiwai nilai-nilai keTuhan Yang maha Esa.

2) Sila Kemanusian yang adil dan beradab. Sila ini secara sistematis didasari dan dijiwai oleh sila Ketuhanan Yang Maha Esa, serta mendasari dan menjiwai ketiga sila berikutnya. Dalam sila kemanusian terkandung nilai-nilai bahwa negara harus menjunjung tinggi harkat dan martabat manusia sebagai makhluk yang beradab. Oleh karena itu, dalam kehidupan kenegaraan terutama dalam perauran perundang-undangan negara harus mewujudkan tercapainya tujuan ketinggian harkat dan martabat manusia, terutama HAM harus dijamin dalam peraturan perundang-undangan. Kemanusian yang adil dan beradab mengandung nilai suatu kesadaran sikap moral dan tingkah laku manusia yang didasarkan pada potensi budi nurani dalam 
hubungan dengan normanorma dan kebudayaan pada umumnya, baik terhadap diri sendiri, terhadap sesama manusia maupun lingkungannya. Nilai kemanusiaan yang beradab adalah perwujudan nilai kemanusiaan sebagai mahkluk yang berbudaya bermoral dan beragama. Dalam kehidupan bernegara harus senantiasa dilandasai oleh moral kemansusiaan antara lain dalam kehidupan pemerintahan negara, politik, ekonomi, hukum, sosial, budaya, pertahanan dan kemanan serta dalam kehidupan keagamaan.

3) Sila Persatuan Indonesia. Nilai yang terkandung dalam sila persatuan Indonesia tidak dapat dipisahkan dengan dengan sila keempat sila lainnya karena seluruh sila merupakan suatu kesatuan yang bersifat sistematis. Sila persatuan Indonesia didasari dan dijiwai oleh sila Ketuhanan Yang Maha Esa, kemanusiaan yang adil dan beradab serta mendasari dan dijiwai sila kerakyatan yang dipimpin oleh hikmat kebijaksanaan dalam Permusyawaratan/ perwakilan, dan keadilan sosial bagi seluruh rakyat Indonesia. Dalam sila Persatuan Indonesia terkandung nilai bahwa negara adalah penjelmaan sifat kodrat manusia monodualis yaitu sebagai makhluk individu dan makhluk sosial. Negara adalah merupakan suatu persekutuan hidup bersama di antara elemen-elemen yang membentuk negara yang berupa, 
suku, ras, kelompok, golongan maupun kelompok, golongan. Oleh karena itu, perbedaan adalah merupakan bawaan kodrat manusia dan juga merupakan ciri khas elemen-elemen yang membentuk negara. Konsekuensinya negara adalah beraneka ragam tapi satu, mengikatkan diri dalam persatuan yang dilukiskan dalam seloka Bhinneka Tunggal Ika. Perbedaan bukannya untuk diruncingkan menjadi konflik dan permusuhan melainkan diarahkan pada suatu sintesa yang saling menuntungkan yakni persatuan dalam kehidupan bersama untuk mewujudkan tujuan bersama.

4) Sila Kerakyatan yang Dipimpin oleh Hikmat Kebijaksaan dalam Permusyaratan/Perwakilan. Nilai yang terkandung dalam sila kerakyatan yang dipimpin oleh hikmah kebijaksanaan dan perwakilan didasari oleh sila Ketuhanan Yang Maha Esa, kemanusian yang adil dan beradab serta persatuan Indoensia, dan mendasari serta menjiwai sila keadilan sosial bagi seluruh rakyat Indonesia. Nilai filosofis yang terkandung di dalamnya adalah bahwa hakikat negara adalah sebagai penjelmaan sifat kodrati manusia sebagai makhluk individu dan makhluk sosial. Hakikat rakyat adalah merupakan sekelompok manusia sebagai makhluk Tuhan Yang Maha Esa yang bersatu yangt bertujuan mewujudkan harkat dan martabat manusia dalam suatu wilayah negara. Rakyat 
adalah merupakan subjek pendukung pokok negara. Negara adalah dari dan oleh rakyat. Oleh karena itu, rakyat merupakan asal mula kekuasaan negara. Dalam sila kerakyatan terkandung nilai demokrasi yang secara mutlak harus dilaksanakan dalam hidup negara, maka nilai-nilai demokrasi yang terkandung dalam sila kerakyatan di antaranya adalah: a) adanya kebebasan yang disertai dengan tanggungjawab terhadap masyarakat bangsa maupun moral terhadap Tuhan Yang Maha Esa, b) menjunjung tinggi harkat dan martabat kemanusiaan, dan c) menjamin dan memperkokoh persatuan dan kesatuan dalam hidup bersama

5) Keadilan Sosial bagi Seluruh Rakyat Indonesia. Nilai yang terkandung dalam sila keadilan sosial bagi seluruh rakyat Indonesia didasari dan dijiwai oleh sila Ketuhanan Yang Maha Esa, kemanusiaan yang adil dan beradab, persatuan Indoensia, serta kerakyatan yang dipimpin oleh hikmat kebijaksanaan dalam permusyawaratan/perwakilan. Bangsa yang mengedepankan keadilan dan kesejahteraan, yaitu bangsa yang memiliki komitmen dan sikap untuk mewujudkan keadilan dan kesejahteraan merupakan karakteristik pribadi bangsa Indonesia. Karakter berkeadilan sosial seseorang tercermin antara lain dalam per buat an yang mencerminkan sikap dan suasana kekeluargaan 
dan kegotongroyongan; sikap adil; menjaga keharmonisan antara hak dan kewajiban; hormat terhadap hak-hak orang lain

Sebagai suatu sistem nilai Pancasila bagi bangsa Indonesia memiliki keunikan atau kekhasan, karena nilai-nilai Pancasila mempunyai kedudukan atau status yang tetap dan berangkai. Keunikan ini disebabkan, karena masing-masing sila tidak dapat dipisahkan dengan sila lainnya. Kekhususan ini merupakan identitas bagi bangsa Indonesia. Pancasila mempunyai nilai-nilai universal, pada bangsa lain tidak dilaksanakan secara utuh dan menyeluruh sebagaimana bangsa Indonesia dan bangsa lain. Dengan demikian perbedaannya bukan terletak pada sikap ramah tamah, gotong royong dan lain-lain, tetapi tetap terletak pada pengamalan atau penerapan nilai-nilai Pancasila tersebut. Pancasila merupakan pandangan hidup bangsa Indonesia oleh karena itu penerapannya harus ditumbuhkan dan dikembangkan tanpa adanya pemaksaan atau indoktrinasi melainkan harus ditumbuhkan dari dalam hati nurani.

Berdasarkan uraian di atas, Pancasila memiliki nilai-nilai yang apabila diamalkan, maka dapat menjadi pondasi yang kuat dalam membangun bangsa Indonesia ke arah yang lebih baik. Secara teoristis, Pancasila merupakan nilai-nilai dasar yang merupakan gabungan dari nilai instrumental dan nilai praksis. 
Nilai instrumental Pancasila tercermin dalam UUD 1945 maupun hukum perundang- undangan lainnya. Nilai praksis tercermin dalam sikap warga negara Indonesia mengamalkan nilai-nilai Pancasila. Nilai-nilai itu memang bersifat abstrak, umum, dan relatif tidak berubah, namun maknanya selalu bisa disesuaikan dengan perkembangan zaman.

\section{d. Upaya Revitalisasi Nilai-nilai Pancasila sebagai Penguatan Karakter Bangsa}

Franz Magnis-Suseno (2012:11) menyatakan bahwa kita mempunyai etika nasional yang dirumuskan dalam Pancasila. Etika dalam Pancasila bukan hanya sebuah rumusan melainkan merupakan prasyarat agar bangsa Indonesia bisa maju bersama, damai, sejahtera dan memiliki solidaritas sosial yang tinggi. Franz Magnis-Susenomerumuskan etikaPancasila dalam lima pedoman yang mudah dimengerti oleh masyarakat. Kelima pedoman tersebut adalah: 1) tak boleh ada tekanan, ancaman atau paksaan dalam hal agama, 2) dalam situasi apa pun kita bertindak secara beradab, 3)

kita maju dan kita maju bersama 4) mari kita sukseskan demokrasi kita, dan 5) mari kita dahulukan yang miskin dan lemah agar dapat hidup secara manusiawi. Kelima pedoman 
tersebut muncul sebagai reaksi atas kondisi perilaku masyarakat yang sangat mengkhawatirkan seperti saat ini. Pancasila sebagai wujud dari cita-cita dan tujuan bangsa Indonesia di era globalisasi ini semakin diabaikan bahkan ditinggalkan. Oleh karena itu, perlu upaya untuk merevitalisasi atau membangun kembali karakter bangsa yang berpedoman pada nilai-nilai Pancasila.

Kita ketahui bahwa manusia mustahil dapat berdiri sendiri tanpa bantuan orang lain. Kasus tersebut menimbulkan suatu kesadaran bahwa segala yang akan dicapai pada dasarnya membutuhkan bantuan orang lain. Selanjutnya hal tersebut juga melahirkan kesadaran bahwa setiap manusia terpanggil hatinya untuk melakukan hal yang baik bagi orang lain dan lingkungannya. Dalam masyarakat Indonesia yang sangat beraneka ragam corak dan budayanya ini, kemampuan untuk mengendalikan diri dan kepentingan adalah suatu sikap yang mempunyai arti sangat penting dan bahkan merupakan sesuatu yang sangat diharapkan, yang pada gilirannya akan menumbuhkan keseimbangan masyarakat. Dalam pandangan Pancasila, hubungan sosial yang selaras, serasi, dan seimbang antara individu dengan masyarakatnya tidak netral, melainkan dijiwai oleh nilai-nilai yang terkandung dalam sila-sila Pancasila 
sebagai kesatuan. Manusia harus hidup dan bekerja sama dengan manusia lain dalam bermasyarakat (Kaelan, 2010:31).

Dari uraian di atas dapat dikatakan bahwa pendidikan Pancasila merupakan satu aspek penting untuk membangun karakter generasi bangsa. Hampir semua bangsa menempatkan pembangunan pendidikan sebagai prioritas utama dalam program pembangunan nasional. Sumber daya manusia yang bermutu yang merupakan produk pendidikan dan merupakan kunci keberhasilan suatu negara. Tujuan pendidikan nasional yang tercantum dalan Undang-Undang Sistem Pendidikan Nasional No. 20 tahun 2003 menyatakan: "Pendidikan bertujuan untuk berkembangnya potensi peserta didik agar menjadi manusia yang beriman dan bertakwa kepada Tuhan Yang Maha Esa, berakhlak mulia, sehat, berilmu, cakap, kreatif, mandiri, dan menjadi warga negara yang demokratis serta bertanggung jawab". Pernyataanpernyataan di atas tampak jelas bahwa pendidikan harus mampu membentuk atau menciptakan manusia yang dapat mengikuti dan melibatkan diri dalam proses perkembangan, karena pembangunan merupakan proses perkembangan, yaitu suatu proses perubahan yang meningkat dan dinamis. Hal ini berarti bahwa membangun hanya dapat dilaksanakan oleh manusia-manusia yang berjiwa pembangunan, yaitu manusia 
yang dapat menunjang pembangunan bangsa dalam arti luas, baik material, spriritual serta sosial budaya.

Upaya untuk merevitalisasikan kembali nilai-nilai Pancasila dalam kehidupan bermasyarakat perlu dilakukan untuk meminimalkan agar tingkat degradisasi moral dapat menurun. Ada beberapa upaya yang dapat dilakukan, di antaranya sebagai berikut.

2) Peningkatan Perhatian Masyarakat Terhadap Nilai-Nilai Pancasila

Dalam mengha lau dampak negatif berkembangnya berbagai ideologi negara lain termasuk kuatnya pengaruh ideologi leluhur ditengah-tengah masyarakat, maka perhatian masyarakat terhadap nilai-nilai Pancasila harus kembali dapat ditingkatkan melalui serangkaian upaya dan kegiatan sebagai berikut.

a) Mengunggah dan mensosialisasikan secara terus menerus eksistensi dan keberadaan ideologi Pancasila sebagai pemersatu untuk membangkitkan kembali rasa nasionalisme dikalangan pemimpin politik, pengusaha, pemuda dan tokoh tokoh agama.

b) Meningkatkan filter/ saringan masyarakat terhadap eksistensi ideologi kapitalis dan liberalis yang mencoba untuk memecah belah Indonesia disemua aspek politik, ekonomi dan sosial budaya. 
c) Meningkatkan intensitas pemberian materi pelajaran pendidikan Pendidikan Pancasila seperti pendidikan moral Pancasila pada tataran teori maupun praktik kepada para siswa/mahasiswa pada semua jenjang pendidikan. Pengemasan materi pelajaran tersebut harus ditampilkan semenarik mungkin dan menghindari kesan adanya doktrinasi sebagaimana pernah terjadi pada masa lalu. Berdasarkan hasil survei Badan Pusat Statistik (BPS) sepanjang 27-29 Mei 2011 dengan 12.056 responden lewat mewawancarai/tatap muka kepada pelajar, mahasiswa, ibu rumah tangga, pengusaha, tokoh masyarakat, TNI, Polri, dan lainnya yang di 181 kabupaten/kota di 33 provinsi. Pada survei itu diajukan pertanyaan "Bagaimana cara yang tepat untuk memahami Pancasila?" Hasilnya, 30 persen melalui pendidikan, 19 persen melalui teladan dari pejabat negara dan pemerintah, 14 persen melalui teladan dari tokoh masyarakat, 12 persen melalui media massa, dan 10 persen melalui ceramah keagamaan. Ketika ditanya siapa yang paling tepat melakukan edukasi dan sosialisasi Pancasila, 43 persen responden menyatakan para guru dan dosen, 28 persen tokoh masyarakat dan pemuka agama, 20 persen badan khusus pemerintah seperti BP 7, dan 3 persen responden memilih elite politik. 
3) Penyamaan Interpretasi Pemahaman Nilai-Nilai Pancasila. Kenyataan saat ini, interpretasi masyarakat terhadap nilai-nilai Pancasila seringkali terdapat perbedaan kerap menimbulkan adanya kesalahan dalam penafsiran penjabaran dari suatu sila, sehingga timbul benturan antarmasyarakat yang dapat merusak persatuan dan kesatuan bangsa. Oleh karena itu, guna menghindari hal tersebut, maka diperlukan adanya penyamaan interpretasi pemahaman nilai-nilai Pancasila yang dilaksanakan melalui berbagai kegiatan sebagai berikut.

a) Sosialisasi nilai-nilai Pancasila dengan memanfaatkan tokoh masyarakat. Upaya sosialisasi ini dapat dilakukan oleh jajaran pemerintah setempat, anggota DPRD, serta aparat TNI atau Polri.

b) Pengkajian terhadap kondisi penghayatan nilai-nilai Pancasila. Upaya ini dapat dilakukan oleh jajaran pemerintahan setempat dengan melibatkan kalangan akademisi dan tokoh-tokoh masyarakat. Pengkajian dilakukan terhadap nilai-nilai Pancasila beserta relevansinya terhadap berbagai perkembangan yang terjadi.

c) Pemerintah melalui Kemendagri dan Kemendiknas merumuskan kebijaksanaan dan program penyusunan buku pedoman/ arahan umum implementasi nilai-nilai Pancasila dan menjadikan buku tersebut sebagai bahan bacaan wajib bagi seluruh aparatur 
penyelenggara negara di berbagai instansi pemerintah, kalangan swasta maupun dunia pendidikan.

d) Pemerintah melalui Kemendiknas menyusun seperangkat kebijakan dan program penataan kurikulum pendidikan materi Pancasila dengan mengacu pada buku pedoman/arahan umum implementasi nilai-nilai Pancasila, sehingga ada kesamaan dan kesinambungan dalam interpretasi nila-nilai Pancasila dari pusat sampai ke daerah.

4) Penataan Kelembagaan Formal Terstruktur Sebagai Pengawas Dan Pengembangan Nilai-Nilai Pancasila Secara Formal.

Kelembagaan formal terstruktur yang diterapkan secara terstruktur/ melembaga, maupun melalui sistem pendidikan nasional yang menyangkut program membudayakan dan memasyarakatkan Pancasila di berbagai lingkungan organisasi kemasyarakatan maupun lingkungan pendidikan dapat terbentuk, sehingga dapat terwujud lembaga yang mengawasi, mengembangkan Pancasila secara formal. Untuk itu diperlukan adanya berbagai upaya sebagai berikut.

a) Pemerintah/Pemda bekerjasama dengan kalangan akademisi merumuskan kebijakan pembentukan Lembaga Pengkajian dan Pelestarian Nilai-nilai. 
b) Pemerintah menetapkan peraturan perundang- undangan yang mengatur tugas, tanggung jawab dan kewenangan yang diberikan kepada Lembaga Pengkajian dan Pelestarian Nilai-Nilai Pancasila, agar lembaga ini memiliki dasar, pedoman dan payung hukum memadai dalam menjalan tugas dan fungsinya

c) Pemerintah/Pemda meningkatkan komunikasi, koordinasi, dan kerjasama dalam merumuskan berbagai aturan mengenai mekanisme kerja Lembaga Pengkajian dan Pelestarian NilaiNilai Pancasila dalam menjalankan tugas dan fungsinya.

d) Pemerintah/Pemda melaksanakan sosialisasi secara menyeluruh mengenai keberadaan Lembaga Pengkajian dan Pelestarian NilaiNilai Pancasila.

Pendidikan merupakan cara yang ampuh untuk menanamkan nilai-nilai Pancasila yang kini terindikasi sudah mulai dilupakan. Apalagi di era globalisasi sekarang ini Pancasila sebagai ideologi bangsa Indonesia sudah mulai terkikis. Oleh sebab itu, untuk membangkitkan semangat nilai-nilai yang ada dalam Pancasila diperlukan pengaplikasian sejak dini. Untuk itu, pendidikan karakter yang akan diaplikasikan pemerintah sangat diperlukan agar Pancasila tidak hanya jadi sekedar omongan, tetapi juga diaplikasikan. Sebaiknya pengamalan nilai-nilai Pancasila harus selalu di pegang teguh oleh peserta didik dalam 
menghadapi tantangan era globalisasi. Salah satu benteng yang paling ampuh adalah dengan memahami nilai-nilai Pancasila, sehingga dapat diaplikasikan. Peranan guru juga sangat dibutuhkan dalam membimbing anak didik. Selain itu, Pancasila diajarkan pengamalannya di rumah oleh orang tua, karena pendidikan bukan sepenuhnya tanggung jawab sekolah. Pengamalan nilai-nilai Pancasila terutama sila pertama harus diajarkan mulai dari tingkat keluar ga, karena siswa menghabiskan sebagian besar waktunya di rumah bersama keluarga.

\section{e. Hakikat Nilai Sila-Sila Pancasila}

Tentang hakikat sila-sila Pancasila perlu ditengarai makna dan arti dari setiap sila Pancasila secara hakiki agar mendapatkan gambaran tentang inti arti Pancasila. Maka, sudah tepat hanya lima sila itu yang dimasukan dalam dasar filsafat negara sebagai inti kesamaan dari segala keadaan yang beraneka warna dan juga telah mencukupi, dalam arti tidak ada lainnya yang tidak dapat dikembalikan kepada salah satu sila Pancasila. Notonegoro (Pandji Setijo, 2010:18).

Sila Pertama; Ketuhanan Yang Maha Esa. Mengandung pengertian dan keyakinan adanya Tuhan YME, pencipta alam 
semesta beserta isinya. Negara Kesatuan Republik Indonesia (NKRI) ditegaskan meskipun bukan negara agama, bukan juga negara sekuler melainkan adalah negara beragama. Bukan negara agama karena tidak menerapkan hukum agama tertentu sebagai hukum positif. Bukan pula negara sekuler yang memisahkan urusan negara dan urusan agama, sedangkan negara beragama dimaksud bahwa NKRI perlu hukum positif yang disepakati oleh seluruh bangsa, termasuk seluruh penyelenggara negara yang agamanya beraneka ragam dan negara wajib melindungi segenap agama yang diakui serta negara tidak dibenarkan mencampuri urusan akidah agama apapun.

Sila Kedua; Kemanusiaan yang adil dan beradab. Kemanusiaan berasal dari kata manusia yaitu manusia berbudi yang memiliki potensi pikir, rasa, karsa dan cipta karena berpotensi menduduki martabat yang tinggi. Adil mengandung arti bahwa suatu keputusan dan tindakan didasarkan atas normanorma yang objektif, tidak subjektif apalagi sewenang-wenang dan otoriter. Beradab berasal dari kata adab, memiliki arti budaya yang telah berabad-abad dalam kehidupan manusia. Jadi beradab berarti berkebudayaan yang lama berabad-abad, bertata kesopanan, dan bermoral. 
Sila Ketiga; Persatuan Indonesia. Persatuan berasal dari kata satu berarti utuh tidak terpecah-belah, mengandung bersatunya bermacam corak yang beraneka ragam yang bersifat kedaerahan menjadi satu kebulatan secara nasional. Selain itu, persatuan bangsa yang bersifat nasional mendiami suatu wilayah Indonesia, bersatu menuju kehidupan bangsa yang berbudaya bebas dalam wadah negara kesatuan rebublik Indonesia yang merdeka dan berdaulat menuju terbentuknya suatu masyarakat madani.

Sila Keempat; Kerakyatan yang dipimpin oleh hikmat kebijaksanaan dalam permusyawaratan perwakilan. Sila ini mengandung arti bahwa rakyat dalam NKRI menjalankan keputusannya dengan jalan musyawarah yang dipimpin oleh pikiran yang sehat serta penuh tanggungjawab dari para pemimpin yang profesional, baik kepada Tuhan YME maupun kepada rakyat yang diwakilinya.

Sila Kelima; Keadilan sosial bagi seluruh rakyat Indonesia. Keadilan sosial berarti keadilan yang berlaku dalam masyarakat segenap bidang kehidupan. Seluruh rakyat Indonesia berarti setiap orang yang menjadi rakyat Indonesia baik yang berada di dalam maupun di luar negeri. Jadi, setiap bangsa 
Indonesia mendapat perlakuan yang adil dibidang hukum, politik, social, ekonomi dan budaya.

Pancasila secara bulat dan utuh sangat sesuai menjadi milik bangsa Indonesia sebagai dasar dan ideologi negara. Setiap warganegara Indonesia wajib memahami makna dari sila-sila Pancasila dan menjadikan nilai-nilai Pancasila sebagai landasan bersikap dan berperilaku dalam kehidupan bermasyarakat, berbangsa dan bernegara.

Secara ringkas (Yudi Latif, 2011) menguraikan pokokpokok moralitas dan haluan kebangsaan kenegaraan menurut alam Pancasila sebagai berikut: Pertama; munurut alam pemikiran Pancasila, nilai-nilai ketuhanan (religiusitas) sebagai sumber etika dan spiritualitas dianggap penting sebagai fundamentaletika kehidupan bangsa. Kedua; menurut alam Pancasila, nilai nilai kemanusiaan universal yang bersumber dari hukum Tuhan, hukum alam, dan sifat-sifat sosial manusia (yang bersifat horizontal) dianggap penting sebagai fundamental etika politik kehidupan bernegara dalam pergaulan dunia. Landasan etika sebagai prasarat persaudaraan universal ini adalah adil dan beradab.

Ketiga; menurut alam pemikiran Pancasila, aktualisasi nilai-nilai etis kemanusiaan itu terlebih dahulu harus mengakar 
kuat dalam lingkungan pergaulan kebangsaan yang lebih dekat sebelum menjangkau pergaulan dunia yang lebih jauh. menurut alam pemikiran Pancasila, Persatuan dari kebhinnekaan masyarakat Indonesia dikelola berdasarkan konsepsi kebangsaan yang mengekspresikan persatuan dalam keragaman, dan keragaman dalam persatuan yang dalam slogan negara dinyatakan dalam ungkapan Bhinneka Tunggal Ika. Keempat; menurut alam pemikiran Pancasila, nilai ketuhanan, nilai kemanusiaan dan cita-cita kebangsaan itu dalam aktualisasinya harus menjunjung tinggi kedaulatan rakyat dalam semangat permusyawaratan yang dipimpin oleh hikmat kebijaksanaan. Kelima; menurut alam pemikiran Pancasila, dalam visi keadilan sosial menurut Pancasila yang dikehendaki adalah keseimbangan antara pemenuhan kebutuhan jasmani dan rohani, keseimbangan antara peran manusia sebagai mahluk individu, mahluk sosial, juga keseimbangan atara pemenuhan hak sipil dan politik dengan hak ekonomi, sosial dan budaya. 


\section{Budaya}

\section{Budaya Daerah sebagai Sumber Karakter Bangsa}

Masyarakat Indonesia bersifat Multi-pluralis, karena terdiri atas berbagai suku, etnik, bahasa, dan agama, namun tetap merupakan satu kesatuan budaya dan ideologis sesuai dengan moto "Bhinneka Tunggal Ika" (Umar, 2015: p.1).

Dari berbagai sumber, Samani dan Hariyanto (2011: 6077) memaparkan tentang nilai-nilai budaya daerah yang turut berperan dalam perumusan nilai-nilai karakter bangsa. Nilai-nilai tersebut dapat diringkas sebagai berikut:

a. Budaya Batak

1) Dalihan na Tolu (tungku berkaki tiga) mengandung nilai seimbang, harmonis, rendah hati, hormat menghormati, kasih sayang

2) Dos ni roha sibaen na saut (musyawarah untuk mufakat) mengandung nilai Spontanitas, terbuka, langsung, tenggang rasa, dan consensus

3) Horja (kerja; aktifitas yang melibatkan tanggung jawab secara lahir dan batin) mengandung nilai Ikhlas dan tulus

b. Budaya Sunda 
1) Silih Asih mengandung nilai religius (nilai-nilai ketuhanan), saling menghormati, dan adil.

2) Silih Asah mengandung nilai bekerjasama, mandiri, dan semangat ilmiah.

3) Silih asuh mengandung nilai peduli terhadap sesama

4) Cageur (sehat) mengandung nilai sehat jasmani dan rohani

5) Bageur (baik) mengandung nilai baik dalam bicara dan perbuatan

6) Bener (benar) mengandung nilai benar dalam tujuan hidup dan perbuatan

7) Singer mengandung nilai (muhasabah, mawas diri) mengandung nilai tidak terjerumus dalam perilaku salah dan keliru

8) Pinter (cerdas) mengandung nilai tidak berhenti dalam mencari dan mengembangkan ilmu.

c. Budaya Jawa

1) Tri Rahayu (tiga kesejahteraan)

- Maтayu hayuning salira mengandung nilai hidup untuk meningkatkan kualitas diri pribadi

- Mamayu hayuning bangsa mengandung nilai berjuang untuk Negara dan bangsa

- Mamayu hayuning bawana mengandung nilai membangun kesejahteraan dunia 
2) Berbudi bawa leksana mengandung nilai berbudi luhur dan rendah hati, tawaddhu

3) Kaprawiran mengandung nilai berlaku perwira dalam segala sesuatu

4) Temen mengandung nilai Jujur

5) Tanggap mengandung nilai bertindak antisipatif

6) Tatag mengandung nilai teguh hati

7) Tangguh mengandung nilai tidak mudah kalah/menyerah

8) Tanggon mengandung nilai berani

9) Datan melik pawehing liyan mengandung nilai tidak mengharapkan bantuan orang lain

d. Budaya Madura

Diambil dari beberapa syair lagu Madura, yaitu:

1) Lir Saalir mengandung nilai berhati-hati dalam bekerja, bertindak, bertingkah laku, berbicara, dan bersikap.

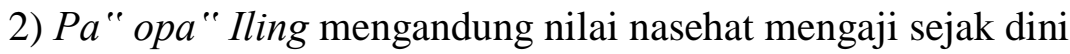

3) Caca Aghuna mengandung nilai berhati-hati dalam berucap dan menggunakan tata krama dalam berbicara

4) Les Balesan mengandung nilai nasehat agar anak muda selalu rajin mencari ilmu, semangat kekeluargaan, saling membantu, gotong royong.

e. Budaya Bugis 
Panngaddereng (lima unsur pokok norma hidup):

1) Ade" mengandung nilai tata tertib yang bersifat normatif

2) Bicara mengandung nilai aturan formal yang menyangkut peradilan dalam arti luas

3) Rappang mengandung nilai aturan tak tertulis untuk mengokohkan Negara dengan segenap undang-undang

4) Wari" mengandung nilai ketentuan dari bagian ade" yang mengatur batas-batas hak dan kewajiban setiap orang dalam hidup bermasyarakat

5) Sara" mengandung nilai berasal dari syariee at agama Islam

Pemaparan tentang nilai-nilai karakter dalam budaya di beberapa daerah di Indonesia di atas dapat membuktikan bahwa menurut fitrahnya, manusia adalah baik dan menyukai kebaikan. Adanya perbedaan budaya justru membuat bangsa Indonesia maju, sikap saling menghargai dan menghormati nilai-nilai budaya merupakan satu pendekatan dalam membangun karakter. Berdasarkan budaya-budaya daerah yang tumbuh di tengah masyarakat, maka lahirlah apa yang disebut budaya bangsa. Budaya bangsa inilah yang mencerminkan karakter bangsa Indonesia. 


\section{Membangun Karakter Anak dengan Budaya Kearifan Lokal dalam Proses Pembelajaran}

Sejarah menunjukkan, masing-masing etnis dan suku memiliki kearifan lokal sendiri. Misalnya, suku Batak kental dengan keterbukaan, suku Jawa nyaris identik dengan kehalusan, suku Madura memiliki harga diri yang tinggi, dan etnis Cina terkenal dengan keuletan. Lebih dari itu, masing-masing memiliki keakraban dan keramahan dengan lingkungan alam yang mengitari mereka. Kearifan lokal itu tentu tidak muncul sertamerta, tapi berproses panjang sehingga akhirnya terbukti, bahwa hal itu mengandung kebaikan bagi kehidupan mereka. Keterujiannya dalam sisi ini membuat kearifan lokal menjadi budaya yang mentradisi, melekat kuat pada kehidupan masyarakat. Semua, terlepas dari perbedaan intensitasnya, mengeram visi terciptanya kehidupan bermartabat, sejahtera dan damai. Dalam bingkai kearifan lokal ini, masyarakat bereksistensi, dan berkoeksistensi satu dengan yang lain.

Kearifan lokal dapat didefinisikan sebagai kebijaksanaan atau nilai-nilai luhur yang terkandung dalam kekayaan-kekayaan budaya lokal berupa tradisi, petatah-petitih, kata-kata bijak dan semboyan hidup (Pikiran Rakyat, 4 Oktober 2004). Pengertian kearifan lokal dilihat dari kamus Inggris Indonesia, terdiri dari 2 
kata yaitu kearifan (wisdom) dan lokal (local). Local berarti setempat dan wisdom sama dengan kebijaksanaan. Dengan kata lain maka local wisdom dapat dipahami sebagai gagasangagasan, nilai-nilai, pandangan-pandangan setempat (local) yang bersifat bijaksana, penuh kearifan, bernilai baik, yang tertanam dan diikuti oleh anggota masyarakatnya. Dengan demikian membangun pendidikan karakter disekolah melalui budaya kearifan lokal sangatlah tepat. Hal ini dikarenakan pendidikan yang berbasis kearifan lokal adalah pendidikan yang mengajarkan pada peserta didik untuk selalu dekat dengan situasi konkrit yang mereka hadapi sehari-hari. Model pendidikan berbasis kearifan lokal merupakan sebuah contoh pendidikan yang mempunyai relevansi tinggi bagi kecakapan pengembangan hidup, dengan berpijak pada pemberdayaan ketrampilan serta potensi lokal pada tiap-tiap daerah. Kearifan lokal milik kita sangat banyak dan beraneka ragam karena Indonesia terdiri atas bermacam-macam suku bangsa, berbicara dalam aneka bahasa daerah, serta menjalankan ritual adat istiadat yang berbeda-beda pula.

Masyarakat Indonesia sudah selayaknya kembali kepada jati diri mereka melalui pemaknaan kembali dan rekonstruksi nilai-nilai luhur budaya mereka. Upaya yang perlu dilakukan adalah menguak makna substantif dari budaya kearifan lokal. 
Contohnya adalah sikap keterbukaan dapat dikembangkan dan diaktualisasikan menjadi nilai kejujuran, toleransi, demokratis dan komunikatif. Kehalusan dapat diaktualisasikan sebagai nilai keramahtamahan, bersahabat, mudah bergaul dan bekerja sama dengan orang lain. Harga diri diletakkan dalam upaya pengembangan nilai disiplin, kerja keras, mandiri dan berprestasi. Pada saat yang sama, hasil rekonstruksi ini perlu dibumikan dan disebarluaskan ke dalam seluruh masyarakat sehingga menjadi identitas kokoh bangsa, bukan sekadar menjadi identitas suku atau masyarakat tertentu.

Persoalannya adalah bagaimana mengimplementasikan kearifan lokal untuk membangun pendidikan karakter anak dalam proses pembelajaran di sekolah? Perlu ada revitalisasi budaya lokal (kearifan lokal) yang relevan untuk membangun pendidikan karakter. Hal ini dikarenakan kearifan lokal di daerah pada gilirannya akan mampu mengantarkan siswa untuk mencintai daerahnya. Kecintaan siswa pada daerahnya akan mewujudkan ketahanan daerah. Ketahanan daerah adalah kemampuan suatu daerah yang ditunjukkan oleh kemampuan warganya untuk menata diri sesuai dengan konsep yang diyakini kebenarannya dengan jiwa yang tangguh, semangat yang tinggi, serta dengan cara memanfaatkan alam secara bijaksana. 
Dalam konteks tersebut di atas, kearifan lokal menjadi sangat relevan. Anak bangsa di negeri ini sudah sewajarnya diperkenalkan dengan lingkungan daerah sekitarnya. Melalui pengenalan lingkungan yang paling kecil, maka anak-anak kita bisa mencintai desanya. Apabila mereka mencintai desanya mereka baru mau bekerja di desa dan untuk desanya. Kearifan lokal mempunyai arti sangat penting bagi anak didik kita. Dengan mempelajari kearifan lokal anak didik kita akan memahami perjuangan nenek moyangnya dalam berbagai kegiatan kemasyarakatan. Nilai-nilai kerja keras, pantang mundur, dan tidak kenal menyerah perlu diajarkan pada anak-anak kita. Dengan demikian, pendidikan karakter melalui kearifan lokal seharusnya mulai diperkenalkan oleh guru kepada para siswanya.

Dari berbagai literatur, ternyata kecerdasan otak yang tercermin dalam kemampuan akademik seseorang hanya akan memberikan sumbangan untuk kesuksesan hidupnya sebesar 20\%. Hal ini menunjukkan bahwa kecerdasan intelektual bukan satu-satunya penentu keberhasilan seseorang dalam hidupnya, tetapi masih banyak kecerdasan lain yang perlu dikembangkan secara simultan dalam proses pembelajaran di sekolah. Menurut berbagai sumber penentu terbesar dalam keberhasilan seseorang dalam hidupnya adalah sikap.Bahkan sikap ini memberikan 
kontribusi hampir $80 \%$ terhadap keberhasilan seseorang. Oleh karena itu pendidikan yang mengembangkan pembentukan sikap positif menjadi sangat penting. Sikap positif ini tidak lain adalah nilai-nilai karakter yang sesuai dengan falsafah dan pandangan hidup bangsa.

Semua guru yang mengajar dan mendidik di sekolah, diharapkan mendidik dengan hati dalam rangka membentuk sikap positif siswanya. Guru dilatih untuk mendesain sendiri rancangan pembelajarannya sehingga apa yang terpikir secara baik oleh guru dapat segera diajar-latihkan kepada siswa agar siswa memiliki dasar-dasar sikap positif untuk melanjutkan pendidikannya. Beberapa kalimat bijak yang berbasis kearifan lokal dapat digunakan sebagai dasar pembangunan sikap positif pendidikan karakter. Kata-kata bijak yang merupakan bagian dari budaya kearifan lokal tersebut, antara lain sebagai berikut

\section{a. Rame ing Gawe, Sepi ing Pamrih}

Kata-kata bijak ini memiliki arti yang mengandung sebuah perintah atau ajakan. Yaitu ajakan agar seseorang senantiasa berbuat baik kepada siapapun, tanpa ada pilih kasih. Setelah berbuat baik seseorang diajak untuk tidak mengharapkan imbalan (pamrih) sedikitpun dari apa yang telah ia perbuat. Kata bijak ini juga mengajarkan kepada kita untuk selalu 
mengutamakan bekerja, bekerja, dan bekerja dan tidak terlalu berharap akan pujian. Dari ungkapan kata tersebut bisa dibayangkan, apa yang akan terjadi di Jawa khususnya jika sebagian besar masyarakatnya bisa memaknai dan mengaplikasikan ungkapan tersebut dalam kehidupan seharihari? Pertanyaan berikutnya adalah apa yang akan terjadi di negara Indonesia, jika semua pemimpin dan pejabatnya yang berasal dari suku Jawa bisa memaknai dan mengaplikasikannya dalam aktifitas kepemerintahannya? Dari ungkapan tersebut sekarang bisa terlihat bahwa sebenarnya nilai dari sebuah budaya lokal adalah sesuatu yang hebat.

b. Ing Ngarsa Sung Tulada, ing Madya Mangun Karsa, Tutwuri Handayani

Kata-kata bijak ini adalah sebuah ajakan agar seseorang bisa menyelesaikan dengan kondisi dan posisinya masingmasing. Apabila ia menjadi seorang pimpinan maka ia mampu menjadi suri teladan yang baik, apabila ia berposisi menjadi seorang penggerak (menteri/ pejabat tinggi) maka ia mampu memelihara kualitas kinerjanya, dan apabila ia menjadi seorang pejabat/ pegawai/ aparat perintah dan sebagainya maka ia sanggup menjaga dedikasi (memberi kekuatan/ dukungan).

c. Becik Ketitik Ala Ketara 
Kata-kata bijak ini memberi inspirasi kepada siapa saja, bahwa pada akhirnya seseorang akan menuai apa yang telah ditanamnya. Dengan begitu tidak ada alasan bagi seseorang untuk melakukan suatu perbuatan yang buruk, karena pada akhirnya sudah pasti orang tersebut tidak akan bisa mendapatkan kebahagiaan.

\section{d. Manungso bakal ngundhuh wohing pakarti}

Maknanya bahwa sebenarnya manusia hanya akan memetik atau memanen apa yang dilakukan selama hidupnya. Oleh karena itu dalam proses pembelajaran harus selalu diingatkan dan dilatihkan bahwa setiap orang selama hidupnya akan merasakan apa saja yang telah dilakukannya. Apabila yang dilakukan lebih banyak kebaikan, maka yang akan diperolehnya adalah kebaikan dan sebaliknya apabila yang dilakukan perbuatan yang kurang baik, maka sepanjang hidupnya juga akan memetik hal-hal yang kurang menyenangkan.

e. Ajining diri soko lathi

Maksudnya harga diri seseorang tergantung dari ucapannya. Dalam konteks ini guru dan siswa harus selalu berlatih, berbicara dengan kata-kata yang baik, sopan dan jujur. Karena hal tersebut akan mencerminkan harga diri dan 
kehormatan seseorang. Orang lain akan menghormati kita karena tutur bahasa kita. Kata bijak ini akan dapat mengembangkan nilainilai karakter kejujuran dan toleransi.

f. Rukun agawe santoso

Ungkapan ini mempunyai makna bahwa dalam hidup baik itu dalam lingkungan keluarga, masyarakat, sekolah, berbangsa dan bernegara apabila dilandasi kerukuan menjadi kokoh dan kuat. Sebaliknya apabila dalam perjalan hidup ini tidak mau bersatu dengan orang lain, tidak peduli, individualistis, tidak bersahabat, maka kehidupan terasa sulit dan apabila ada permasalahan akan cepat putus asa. Kata bijak ini dapat mengembangkan nilai-nilai karakter bersahabat komunikatif,yang memperlihatkan rasa senang bergaul dan bekerjasama dengan orang lain, punya kepedulian sosial, yaitu sikap yang selalu igin memberi bantuan pada orang lain dan masyarakat yang membutuhkan.

g. Mikul dhuwur mendem jero.

Kata bijak ini mempunyai makna bahwa kita harus bisa menghargai setinggi mungkin jasa orang tua kita atau para 
pendahulu kita dan kita harus dapat menutup rapat-rapat kesalahan atau dosa orang tua atau pendahulu kita.

h. Bapantang kusuik nan tak salasai

Kata bijak tersebut mempunyai makna ketika seseorang atau sekelompok orang sudah memulai suatu pekerjaan atau kegiatan, apapun masalah atau hambatannya harus dapat diselesaikan, baik secara sendiri-sendiri ataupun bersama-sama. Nilai karakter yang dapat dikembangkan dari kata bijak tersebut adalah kerja keras, tanggungjawab terhadap tugas dan menghargai prestasi.

i. Sekali langkah diayun, pantang untuk kembali.

Makna dari kata bijak tersebut adalah, apabila kita sudah memulai kegiatan atau program harus dikerjakan sampai selesai, apapun hasilnya. Hal ini memberikan implikasi bahwa seseorang kalau sudah mulai mengerjakan sesuatu harus terus bekerja dan tak akan pernah berhenti sebelum sampai ke tujuan. Nilai karakter yang dapat dikembangkan dari kata bijak ini adalah kedisiplinan, rasa tangggungjawab, dan kerja keras.

Makna dari kata bijak ini dapat digunakan untuk mengingatkan dan melatih siswa agar selalu menjadi manusia yang tangguh. Guru dapat menjelaskan tipe-tipe manusia dalam mewujudkan cita-citanya. Ada orang yang mudah menyerah 
ketika baru mulai menghadapi kesulitan dalam berusaha (quitters). Kebanyakan orang akan berhenti berusaha sebelum tenaga dan batas kemampuan mereka benar-benar teruji (campers). Sebagian lagi terus berusaha apapun rintangannya sampai berhasil mencapai tujuan (climbers).(Bejo Sujanto,2012:4)

Dengan memberikan ilustrasi tentang tipe-tipe manusia tersebut, siswa akan tahu bahwa ada manusia yang mudah menyerah menghadapi tantangan, akibatnya mereka tidak akan mampu meraih impian hidupnnya karena memilih jalan yang dianggap mudah dan mengabaikan potensinya. Ada juga tipe manusia yang menyerah sebelum usahanya maksimal, mereka hanya mengisi hidupnya yang dianggap nyaman dan mengorbankan hal-hal yang mungkin masih bisa diraihnya. Selanjutnya tipe manusia yang tangguh dan tidak mudah menyerah, dan mereka inilah yang akan berhasil mewujudkan puncak cita-cita atau impiannya.

j. Kehidupan yang besar selalu dimulai dengan impian-impian besar

Makna dari kata bijak tersebut adalah dalam hidup ini apabila kita ingin mencapai kesuksesan maka mulailah dengan impian-impian besar mengenai apa yang kita cita-citakan. Impian 
akan memberikan motivasi kepada seseorang untuk berusaha mewujudkannya. Nilai karakter yang dapat dikembangkan dari kata bijak ini adalah kerja keras, disiplin, rasa ingin tahu, mandiri, dan menghargai prestasi demi tercapainya impian besarnya.

Dalam proses pembelajaran guru harus dapat memotivasi dan meyakinkan kepada siswa, bahwa setiap manusia itu di samping mempunyai kekurangan juga mempunyai kelebihankelebihan. Hal tersebut sangat penting dijelaskan kepada siswa, agar siswa yang merasa memiliki kekurangan tidak berputus asa akibat kekurangannya tersebut, karena setiap orang juga mempunyai kelebihan dan harus yakin bahwa dengan kelebihannya tersebut mereka pasti dapat berhasil disetiap apa yang diusahakan. Oleh karena itu, kepada siswa perlu dijelaskan juga bahwa, hidup seperti kunci kombinasi, tugas dari kita adalah menemukan angka-angka yang tepat dengan urutan yang tepat, sehingga kita dapat membuka pintu kesuksesan. Tidak ada resep khusus yang membuat orang sukses, kecuali berusaha maksimal, yang berbentuk kerja keras, belajar rajin, punya rasa ingin tahu yang tinggi, disiplin, dan ulet. Harta yang paling berharga adalah keinginan kita untuk mau berusaha pantang menyerah. 
Tentu masih banyak lagi kata-kata bijak yang merupakan budaya kearifan lokal yang dapat digunakan untuk mengembangkan karakter anak dalam proses pembelajaran di sekolah. Hal yang paling utama adalah kesungguhan kita sebagai pendidik untuk selalu mendidik dengan hati. Mendidik dengan hati akan mengutamakan pembentukan sikap positif seperti; jujur, toleran, amanah, saling asah dan asuh, optimistis, percaya diri, ulet, tangguh dan lain sebagainya.

\section{Pendidikan Karakter Berbasis Budaya}

Pendidikan karakter berbasis budaya memaknai budaya sebagai suatu hal yang harus dipelajari dan ditransformasikan ke generasi selanjutnya. Kebudayaan suatu bangsa adalah jatidir yang harus dipelajari secara utuh dan dinamis. Karena itu untuk mempertahankan perlu kecderdasan dalam memaknai seuatu dampak kebudayaan. Kebudayaan memiliki makna inivasi dan perubahan dan kebudayaan adalah sumber dari perubahan itu sendiri.

Hubungan fungsional antara pendidikan dan kebudayaan mengandung makna antara lain; Pertama bersifat Reflektif, yaitu gambaran kebudayaan yang berlangsung saat ini, dan Kedua besifat Progresif, yaitu pendidikan bergerak melakukan 
pembaharuan, membawa kebudayaan kearah kemajuan peradaban kemajuan. Kedua hal ini adalah makna dari pendidikan karakter, yaitu dimana proses pendidikan merupakan usaha individu sekaligus upaya inovativ dan dinamis dalam rangka menghadapi perubahan jaman ke arah yang lebih baik lagi.

Dapat dikatakan pendidikan karakter adalah salah satu tujuan akhir dari proses pendiikan. Karakter adalah hasil dari budi . Budi dan nurani bersumber pada moralitas. Sedangkan moralitas bersumber pada suatu kesadaran diri manusia , dan kesadaran manusia berpusat pada alam pikir manusia. Dalam kehidupan manusia kedaran akan jiwa nurani dan alam pikiran harus seimbang. Dengan kesimbangan itu moralitas akan terjaga dan dapat dilakukan. Moralitas ini berpengaruh pada tanggung jawab nilai, hukum dan moral yang dilakukan oleh manusia.

Karakter menurut Lickona terbagi atas beberapa bagian yang tercakup di dalamnya. Sebagaimana yang dikemukakan oleh Lickona di bawah ini:

Character so conceived has three interrelated parts: moral knowing, moral feeling, and moral behavior. Good character consists of knowing the good, desiring the good, and doing the good, habits of the mind, habits of the heart, and habits of action. All three are necessary for leading a moral life, all three make up 
moral maturity. When we think about the kind of character we want for our children, it's clear that we want them to be able to judge what is right, care deeply about what is right, and then do what they believe to be right, even in the face of pressure from without and temptation from withiz.

Russel Willan menggambarkan Pendidikan karakter adalah otot/urat dimana pendidikan karakter akan menjadi lemah apabila tidak dilatih secara rutin dan tidak digunakan. Pendidikan karakter ibarat suatu potensi yang ada di dalam diri setiap manusia dan harus diaktualisasikan agar membentuk otot yang sesuai dengan kehendak melalui proses pendidikan. Banyaknya nilai nilai yang harus dikembangkan dalam proses pendidikan karakter, maka pendidikan karakter kita bagi menjadi tiga bagian utama, yaitu;

1) Keberagamaan; terdiri dari nilai-nilai (a). Kekhususan hubungan dengan tuhan; (b). Kepatuhan kepada agama; (c). Niat baik dan keikhlasan; (d). Perbuatan baik; (e). Pembalasan atas perbuatan baik dan buruk.

2) Kemandirian; terdiri dari nilai-nilai (a). Harga diri; (b). Disiplin; (c). Etos kerja; (d). Rasa tanggung jawab; (e). Keberanian dan semangat; (f). Keterbukaan; (g). Pengendalian diri. 
3) Kesusilaan terdiri dari nilai-nilai (a). Cinta dan kasih sayang; (b). kebersamaan; (c). kesetiakawanan; (d). Tolong-menolong; (e). Tenggang rasa; (f). Hormat menghormati; (g). Kelayakan/ kepatuhan; (h). Rasa malu; (i). Kejujuran; (j). Pernyataan terima kasih dan permintaan maaf (rasa tahu diri).

Dari penjelasan di atas Lickona memberikan 3 bagian penting untuk menjelaskan kerangka bangun pendidikan karakter, yaitu: a. Moral knowing (pengetahuan tentang moral), b. Moral feeling (perasaan tentang moral), c. Moral action (Perbuatan moral)

Tiga hal di atas dapat dijadikan rujukan dalam mengimplementasikan proses pendidikan karakter.

Target selanjutnya adalah sasaran yang menjadi tujuan akhir dari pendidikan karakter. Pertama adalah Kognitif, kedua adalah afektif dan yang Ketiga adalah Psikomotorik. Kognitif adalah megisi dan mengajari dari tidak tahu menjadi tahu dan kemudian menjadikan proses itu berkelanjutan atau menjadi budaya sehingga pikiran dapat mempungsikan akalnya menjadi suatu kecerdasan manusia. Afektif, adalah mengenai perasaan, emosional, pembentukan sikap dan sebagainya. Dan yang 
terakhir adalah psikomotorik, ini berkaitan dengan perbuatan, perilaku dan sebagainya

Pendidikan karakter adalah bagaimana seseorang mengetahui tentang baik dan buruk, bertindak dan berperilaku yang sesuai dengan nilai nilai kebaikan sehingga muncul karakter dan kepribadian yang mulia.

Pendidikan karakter menurut Ki Hajar Dewantara adalah: " ngerti, ngerasa, ngelakoni” yang artinya adalah menyadari, menginsyafi dan selanjutnya adalah melakukan. Ki Hajar Dewantara mengharapkan adanya suatu bentuk pendidikan dan pengajaran yang fokus atau menitik beratkan pada perilaku siswa dalam mengapresiasi dan implementasi pada nilai nilai karakter dalam kehidupan sehari hari. Target dari pendidikan karakter adalah terwujudnya peserta didik yang memiliki intregitas moral yang kemudian diimplementasikan pada lingkungan dan kehidupan sehari hari.

Untuk memahami pendidikan karakter maka perlu adanya pendekatan, pendekatan moral dapat digunkan dalam pendidikan karakter. Untuk lebih memahami tentang karakter maka harus dipahami konsep moral. 
Menurut pendapat Hersh (1980) diantara berbagai teori yang berkembang ada enam macam pendekatan teori yang biasa digunakan, yaitu;
a) Pendekatan pengembangan rasional
b) Pendekatan pertimbangan
c) Pendekatan klarifikasi nilai
d) Pendekatan moral kognitif dan
e) Pendekatan perilaku sosial

Berbeda dengan pendekatan di atas, Elias (1980) mengklasifikasikan berbgai teori dalam tiga pendekatan, yaitu;
a) Pendekatan kognitif
b) Pendekatan afektif
c) Pendekatan perilaku

Kemudian menurut Rest (1992) yang dilakukan didasarkan pada tiga unsur moralitas, yaitu perilaku, kognisi dan afeksi. 
Setidaknya terdapat lima pendekatan nilai yang dilakukan, yaitu : (1). Pendekatan penanaman nilai (inculcation approach), (2) Pendekatan perkembangan moral kognitif (cognitive moral development approach), (3) Pendekatan analisis nilai (values analysis approach), (4) Pendekatan klarifikasi nilai (values clarification approach), dan (5). Pendekatan pembelajaran berbuat (action learning approach).

a. Pendekatan Penanaman Nilai

Inculcation approach atau pendekatan penanaman nilai adalah suatu pendekatan dengan penekanan pada nilai-nilai sosial dalam diri siswa. Pendekatan ini adalah pendekatan tradisional. Tujuan pendidikan nilai adalah:

1) Diterimanya nilai-nilai sosial tertentu oleh siswa

2) Berubahnya nilai-nilai siswa yangtidak sesuai dengan nilai-nilai sosial yang diinginkan.

Dalam proses ini metode yang digunakan antara lain adalah; keteladanan, penguatan positif dan negative, simulasi, permainan dan sebagainya. 
Banyak kritik dalam berbagai literatur barat yang ditujukan kepada pendekatan ini. Pendekatan ini dipandang indoktrinatif, tidak sesuai dengan perkembangan kehidupan demokrasi (Banks, 1985; Windmiller, 1976). Pendekatan ini beranggapan mengabaikan hak untuk memilih nilai sendiri secara bebas. . Menurut Raths et al. (1978) kehidupan manusia berbeda karena perbedaan waktu dan tempat. Kita tidak dapat memprediksi nilai apa yang sesuai dengan kehidupan generasi yang akan datang, menurut pendapat di atas bahwa setiap generasi mempunyai hak untuk menentukan sendiri nilai yang sesuai dengan hidupnya. Oleh karena itu yang sangat penting adalah proses dan bukan nilai. Proses merupakan suatu perubahan yang tidak dapat dihindari. Proses perubahan dibutuhkan nilai yang baik dan harus sesuai dengan jamannya.

\section{b. Pendekatan Perkembangan Kognitif}

Pendekatan perkembangan kognitif adalah pendekatan perkembangan karena karakteristinya memerikan penekanan pada aspek kognitif dan perkembangannya. Pada perndekatan ini siswa diajak untuk berpikir aktif tentang masalah moral dalam membuat keputusan. 
Pendekatan ini melihat bahwa Perkembangan moral sebagai perkembangan tingkat berpikir dalam membuat pertimbangan moral, dari suatu tingkat yang lebih rendah menuju suatu tingkat yang lebih tinggi (Elias, 1989).

Pada pendekatan ini memiliki dua tujuan utama yaitu ; Pertama, membantu siswa dalam membuat suatu pertimbangan moral yang lebih kompleks berdasarkan kepada nilai yang lebih tinggi. Kedua, dalam menghadapi masalah moral siswa didorong untuk mendiskusikan alasan-alasannya ketika memilih nilai dan posisinya (Superka, et. al., 1976; Banks, 1985). Maka proses pengajaran nilai pada pendekatan ini didasarkan pada dilema moral dengan menggunakan metode diskusi kelompok. Pendekatan perkembangan kognitif pertama kali dikemukakan oleh Dewey (Kohlberg 1971, 1977). Selanjutkan dikembangkan lagi oleh Peaget dan Kohlberg (Freankel, 1977; Hersh, et. al. 1980). Dewey membagi perkembangan moral anak menjadi tiga tahap (level) sebagai berikut:

1) Tahap "preconventional" atau tahap premoral . yaitu dimana tingkah laku seseorang didorong atau dipengaruhi oleh sesuatu yang bersifat fisikal atau sosial; 
2) Tahap "conventional", dalam tahap ini perilaku seseorang mulai menerima nilai dengan sedikit kritis, hal ini didadarkan pada kriteria kelompoknya.

3) Tahap "autonomous". Dalam tahap ini perilaku seseorang dalam bertingkah laku atau berbuat sesuai dengan pertimbangan dan akalnya sendiri dan sepenuhnya tidak menerima criteria kelompoknya.

Selanjutnya Piaget mendefinisikan pada tingkat perkembangan moral pada anak-anak yang dilakukan dengan pengamatan dan wawancara (Windmiller, 1976). Dari hasil pengamatan yang dilakukan kepada anak-anak saat mereka bermain, dan jawaban anak anak terhadap pertanyaan kenapa mereka patuh kepada peraturan, yang kemudian pada satu kesimpulan yaitu perkembangan kemampuan kognitif pada anakanak mempengaruhi pertimbangan moral mereka. Selanjutnya menurut Kohlberg (1977) juga mengembangkan teorinya berdasarkan kepada asumsi-asumsi umum tentang teori perkembangan kognitif dari Dewey dan Piaget di atas.

Teori ini dinilai paling relevan dan mudah digunakan dalam proses pendidikan di kelas. Karena pendekatan ii memberikan focus tekana pada aspek pengembangan kemampuan berpikir. 
Pemikiran Kohlberg dinilai konsisten dengan teori dan peka untuk membedakan kemampuan dalam membuat suatu pertimbangan, mendukung perkembangan moral dan dapat melebihi berbagai teori lainnya yang berdasarkan hasil penelitian empiris.

c. Pendekatan Analisis Nilai

Value analysis approach, pada pendekatan ini analisis nilai memberikan focus pada kemempuan perkembangan siswa. Siswa didorong untuk berpikir logis dengan menggunakan metode analis yang berhubungan dengan nilai sosial.

Selanjutnya ada enam langkah analisis nilai yang penting dalam suatu proses pendidikan (Hersh, et. al., 1980; Elias, 1989), sebagai berikut:

Langkah Analisis Nilai Tugas Penyelesaian Masalah

1) Mengidentifikasi dan menjelaskan nilai yang terkait

2) Mengurangi perbedaan penafsiran tentang nilai yang terkait

3) Mengumpulkan fakta yang berhubungan 
4) Mengurangi perbedaan dalam fakta yang berhubungan

5) Menguji kebenaran fakta yang berkaitan

6) Mengurangi perbedaan kebenaran tentang fakta yang berkaitan

7) Menjelaskan kaitan antara fakta yang bersangkutan

8) Mengurangi perbedaan tentang kaitan antara fakta yang bersangkutan

9) Merumuskan keputusan moral sementara

10) Mengurangi perbedaan dalam rumusan keputusan sementara

11) Menguji prinsip moral yang digunakan dalam pengambilan keputusan

12) Mengurangi perbedaan dalam pengujian prinsip moral yang diterima

Pada analisis ini pendekatan kognitif menekankan pada pembahsan masalah yang memuat nilai nilai sosial pada lingkungan. Perkembangan kognitif memberikan penekanan pada dilemma moral yang bersifat perseorangan (Superka, 1976).

d. Pendekatan Klarifikasi Nilai 
Pendekatan selanjutnya adalah pendekatan klarifikasi nilai (values clarification approach). Pada fokus ini usaha membantu siswa dalam mengkaji perasaan dan perbuatan untuk meningkatkan kesadaran siswa tentang nilai yang telah dilakukan.

Terdapat tiga tujuan dalam pendidikan ini,. Pertama adalah membantu siswa menyadari dan selanjutnya mengidentifikasi nilai mereka sendiri dan nilai orang lain. Tujuan Kedua adalah agar siswa dapat berkomunikasi secara terbuka dengan orang lain yang berhubungan dengan nilai nilainya sendiri. Dan tujuan Ketiga adalah agar supaya siswa dapat berpikir secara rasional dan kesadaran emosional untuk memahami nilai dan pola mereka sendiri. (Superka, 1976).

Pada pendekatan ini penekanan pada nilai yang sesungguhnya dimiliki oleh seseorang. Penganut pada pendekatan klarifikasi nilai adlah bersifat subyektif dimana ditentukan oleh seseorang berdasarkan kepada latar belakang pengalamannya yang berbeda, selanjutnya titak ditentukan oleh faktor luar seperti kepercayaan kepada supranatural, agama dan lainnya. 
Hal yang sangat penting dalam program pendidikan adalah mengembangkan ketrampilan /skill pada proses menilai. Terdapat tiga proses klarifikasi nilai dalam pendekatan ini. Yaitu; Pertama : Memilih

1) Dengan bebas

2) Dari berbagai alternatif

3) Setelah mengadakan pertimbangan tentang berbagai akibatnya Kedua : Menghargai

1) Merasa bahagia atau gembira dengan pilihannya

2) Mau mengakui pilihannya itu di depan umum Ketiga : Bertindak

1) Berbuat sesuatu sesuai dengan pilihannya

2) Diulang-ulang sebagai suatu pola tingkah laku dalam hidup (Raths, et. Al., 1978)

\section{Kearifan Lokal sebagai Sumber Pendidikan karakter}

Beberapa kandungan pada budaya jawa yang dapat digunakan sebagai pendidikan karakter bisa kita lihat dari ungkapanjawa yang telah di inventarisir Thomas Wiyasa Bratawijaya (1997) berikut :

a. Aja Dumeh 
Aja dumeh ungkapan sederhana tetapi mengandung arti mendalam. Bila diterjemahkan ke dalam Bahasa Indonesia lebih kurang jangan sok. Pengertian aja dumeh adalah suatu sikap seseorang yang mendorong untuk berbuat sewenang-wenangnya menurut kehendak sendiri, sehingga lupa diri. Hal ini karena dipengaruhi oleh mumpung berkuasa sehingga dapat memperlihatkan sayalah yang berkuasa. Ungkapan itu mengingatkan kepada kita jangan sekali-kali berperilaku aja dumeh tersebut. Seperti telah kita uraikan di muka bahwa orang Jawa selalu berusaha jangan sampai kelihatan melebihi orang lain. Bila kita menjadi pemimpin perlu menghindari sikap aja dumeh agar kepemimpinan kita tidak goyah. Hal ini dapat digambarkanseperti Raja Kresna yaitu inggil tan ngukul-ukuli, andhap tan kena ing ngasoran. Artinya ia sebagai Raja Agung tidak ingin melebihi raja-raja lain, namun demikian tidak berarti ia harus merendah. Bersikaplah wajar agar tidak menimbulkan sikap karena sok raja. Masyarakat Jawa dididik supaya jangan mengecewakan dan menyakiti hati orang lain, karena adanya pergantian nasib ke arah yang lebih baik sehingga orang Jawa jangan sampai keweleh artinya dipermalukan. Oleh karena itu orang Jawa ingin selalu mawas diri yaitu ingin mengetahui kekurangan dan kelemahan dirinya. Agar jangan sampai keweleh 
maka orang Jawa menghindari dari sikap aja dumeh dengan cara suka menolong, membantu dan dapat memahami perasaan orang lain atau empati.

b. Tepa selira

Tepa selira secara sederhana dapat diterjemahkan dalam Bahasa Indonesia tenggang rasa. Tepa salira merupakan perilaku seseorang yang mampu memahami perasaan orang lain. Dengan demikian orang yang mempunyai tepa selira tidak akan bertindak sewenang-wenang jika ia menjadi pemimpin. Kalau dicubit merasa sakit, ya, jangan mencubit. Tepa selira artinya mampu memahami perasaan orang lain (empati) dalam dunia barat di kenal dengan isitilah trial by the press. Pada dasarnya seseorang yang mempunyai tepa selira adalah tidak cepat-cepat mengambil kesimpulan untuk menyalahkan orang lain. Tepa selira dapat diartikan pula setiap orang menghotrnati hak-hak azasi manusia dan menghormati pendapat orang lain.

c. Mawas Diri

Mawas diri adalah mengadakan penelitian dan memeriksa di dalam hati nurani, apakah tindakan yang dilakukan sudah benarsesuai dengan norma-norma dan tata nilai ataukah belum.Mawas diri identik dengan anti intronspeksi. Bagi masyarakat Jawa senang menjalankan mawas diri dan berusaha 
untukselalu menjadi pedoman cara bertindak guna mendapat jawaban atas persoalan yang dihadapinya. Hal ini diperlukan agar mengatasi masalah tidak salah langkah. Masyarakat Jawa atau orang Jawa selalu bertindak secara moral dapat dibenarkan dan dapat dipertanggungjawabkan. Jalan yang ditempuh adalah dengan penuh pertimbangan dengan cara menganalisis lebih mendalam berdasarkan hati nurani. Istilah mawas diri telah menjadi istilah yang bukan hanya dilakukan oleh orang Jawa, tetapi sudah membudaya secara nasional. Mawas diri sebagai landasan pemikiran. Apa yang telah kita sumbangkan terhadap pemerintah, sehingga kita tidak banyak menuntut. Mawas diri berarti awal mula seseorang dapat mengendalikan diri dan menahan nafsu angkara murka. Salah satu jalan bagi seseorang agar dapat mawas diri adalah berkomunikasi dengan Tuhan untuk memohon agar apa yang dilakukan adalah menurut kehendakNya. Atau paling tidak bersemedi sejenak untuk menyingkirkan pikiran-pikiran yang tidak baik guna mendapatkan jalan yang paling tepat dalam mengambil keputusan. Seseorang yang melakukan mawas diri berarti ingin jujur yaitu tidak bertentangan hati nuraninya. Kejujuran terhadap hati nurani merupakan jaminan untuk dilaksanakannya dengan pikiran bersih agar mawas diri benar-benar dapat terwujud. Mawas diri bagi 
seseorang berarti ia menginginkan hidup senang, tenteram penuh kedamaian.

d. Budi Luhur

Bagi masyarakat Jawa dalam mendidik putra-putrinya semenjak mereka kecil sudah dididik menimbang baik dan buruknya suatu perbuatan. Pendidikan budi luhur melatar belakangi pendidikan budi pekerti yang diajarkan di dalam lingkungan keluarga basis atau inti, maupun di dalam sekolah oleh para guru. Sayang sekali pendidikan budi pekerti di sekolah dewasa ini kurang mendapatkan perhatian. Hal ini di-sebabkan dalam kurikulum tidak dicantumkan pendidikan budi pekerti. Sedangkan di rumah, kadang-kadang orangtua sibuk di luar rumah untiik mencari nafkah agar kebutuhan rumah tangga yang begitu banyak dapat teratasi. Namun demikian bagi masyarakat Jawa orangtua masih sempat memberikan pendidikan budi pekerti meskipun dalam porsi yang sangat sederhana. Budi luhur adalah perilaku seseorang untuk selalu berbuat yang terbaik dan berbagai kebaikan. Pada prinsipnya kita harus berusaha jangan sampai berbuat jahat dan untuk itu kita harus menjauhkan diri dan perbuatan srei dan drengki. Perbuatan srei adalah perbuatan serakah yaitu ingin mengusai segala-galanya sedangkan drengki adalah iri terhadap ke-berhasilan atau kekayaan orang lain. 
Seseorang yang berbudi luhur selalu berorientasi kepada kepentingan orang lain, senang menolong tanpa pamrih. Ada ungkapan Jawa yang perlu ditekankan di sini yaitu sepi ing pamrih rame ing gawe, arti ungkapan itu adalah bila kita menolong seseorang dari kesulitan adalah tanpa mengharapkan imbalan apa pun. Budi luhur berarti juga mau berkorban demi kepentingan orang lain, terutama mereka yang mengalami kesusahan/kesulitan. Sebenarnya semua perbuatan buruk seseorang berpangkal pada keserakahan dan keirihatiannya. Bertitik tolak dari itulah seseorang akan lupa diri, tidak dapat mengendalikan diri, akibatnya terjerumus ke dalam perbuatanperbuatan yang negatif. Namun bila seseorang memiliki budi luhurakan mampu mengendalikan diri dan terlepas dari belenggu serakah dan iri hati. Seseorang yang memiliki budi pekerti luhur selalu nrima ing pandum artinya menerima apa yang telah diberikan oleh Tuhan. Nrima ing pandum atau menerima apa adanya bukan berarti putus asa tetapi membatasi din untuk berbuat sesuatudi luar aturan agar dapat menerima lebih bahkan berlebihan. Bagi masyarakat Jawa selalu mau menerima apa adanya dengan disertai ikhlas dalam menerima apa yang telah diperolehnya. Apa yang telah diterimanya selalu disyukuri dan ingin berusaha untuk meningkatkan apa yang telah didapatnya. 


\section{e. Sikap Wani Tombok}

Wani tombok berarti berani menanggung rugi demi harga diri. Sikap wani tombok bagi masyarakat Jawa adalah sikap berani menanggung risiko atau rugi. Sikap tersebut merupakan sikap perwira yaitu sikap terpuji karena mau memberi bantuan bila ada kekurangan, misalnya biaya yang seharusnya ditanggung bersama secara patungan ternyata kurang. Kekurangan itulah yang ditanggung orang berani tombok. Berani tombok bagi orang Jawa bukan mencari muka atau pujian, tetapi demi terlaksananya tujuan bersama. Contoh rombongan siswa SMA, mengadakan wisata karya. Dan para siswa sudah ditarik iuran yang jumlahnya sudah diperhitungkan mencukupi. Akan tetapi perhitungan tersebut meleset yaitu ada kekurangan. Maklum ada biaya-biaya tidak terduga. Ada seseorang guru pengasuh yang secara ikhlas bersedia menutupi biaya kekurangan tersebut. Sikap demikianlah yang dinamakan wani tombok, dan sikap itu tidak untuk mencari muka dan pujian tetapi untuk menjaga kewibawaan atau nama baik sekolah. Seharusnya sikap wani tombok ini perlu bagi seorang pemimpin, artinya ia menjadi pemimpin selalu berpikir positif. Berani menanggung risiko termasuk menanggung kekurangan atau biaya. Tetapi apakah sikap wani Lombok ini masih menjiwai para pemimpin kita, mungkin masih banyak atau 
mungkin tidak ada. Malah selalu mencari kesempatandalam kesempitan untuk memeras masyarakat dengan alasan gaji tidak cukup. Sayang sekali bila para pemimpin kita tidak memiliki sikap berani tombok. Berilah pelayanan kepada masyarakat sebaikbaiknya agar mereka puas dengan pelayanan tersebut. Memberi pelayanan yang baik terhadap masyarakat sudah termasuk sikap berani tombok. Dengan prinsip wani tombok itulah masyarakat Jawa memiliki motto sugih tanpa bandba artinya kaya tanpa memiliki harta benda, yang penting banyak kerabat dan kawan. Motto itu mengingatkan masyarakat Jawa bahwa harga did seseorang tidak ditentukan oleh kekayaan harta benda yang dimiliki, tetapi sikap terpuji seperti wani tombok memberi pengaruh positif kepada semua orang Indonesia. Wani tombok merupakan sikap mau berkorban untuk kepentingan umum atau membantu orang lain dalam kesulitan. Orang yang wani tombok tidak hams yang sudah kecukupan atau orang kaya raya, tetapi orang biasa atau orang tidak punya pun bisa berbuat wani tombok. Itulah konsep budaya Jawa sikap wani tombok yang perlu dilestarikan dan dilaksanakan bukan hanya dihayati saja.

f. Mendhem Jero Mikul Dhuwur 
Ungkapan ini harus ditujukan kepada anak-anak atau para remaja kita terutama masyarakar Jawa. Mendhern jero artinya menutupi lubang sedalam-dalamnya dengan tanah yang telah digali, mikul dhuwur artinya mikul = memikul; dhuwur = atas Jadi anti harafiah yaitu menutup, lubang sampai sedalamdalamnya dan memikul sampai atas. Maksud ungkapan tersebut adalah kita sebagai anak atau generasi penerus harus melu-pakan atau melenyapkan keburukan, kejelekan atau kesalahan orangtua apalagi orangtua kita yang sudah meninggal dunia. Bagi orang Jawa, tidak baik mengungkit-ungkit atau mengungkapkan keburukan orang tua dan saudara yang sudah meninggal. Yang perlu dikenang adalah jasa mereka.Orang tua kita merupakan sarana Tuhan agar kita ada di dunia ini. Sedangkan makna dari mikul dhuwur atau memikul sampai di atas adalah sebagai generasi muda perlu menjunjung nama baik orang tua dengan menghindarkan diri dari perbuatan tercela. Apalagi bila para generasi muda memiliki prestasi sehingga membawa nama naik orang tua. Misalnya seperti Yayuk Basuki yang berprestasi dalam dunia olah raga tens dan banyak contoh lain yang mampu membawa nama baik orang tua dan sanak saudara. Oleh karena itu orang tua berjuang keras atau bekerja keras demi untuk menunjang dalam meraih prestasi putra-putrinya, dan paling tidak 
berbudi luhur meskipun tidak berprestasi. Sikap budi pekerti luhur pun merupakan satu indikator mikul dhuwur.Bagaimana kenyataan sekarang, terutama bagi masyarakat Jawa, masih ingatkah ungkapan tersebut. Bila masyarakat kita bukan Jawa saja ada perkelahian pelajai terlibat perampokan dan bentuk-bentuk kriminal lainnya. Sayang para orang tua sudah tidak sempat memberi ular-ular ungkapan yang sangat berharga itu. Contohnya kehidupan keluarga sederhana, meskipun anaknya banyak yaitu 8 orang untuk ukuran keluarga berencana tetapi apa nyatanya. Karena orang tua yang bersangkutan masih selalu memberi pitutur pendidikan/nasihat. Kamu sekalian harus rukun dan yang penting kamu semua harus dapat mendhem jero lan mikul dhuwur. Dengan nasihat itulah mereka semua lulus sarjana dari perguruan tinggi terkenal di Indonesia yaitu Universitas Gajah Mada. Sebaliknya ada yang mempunyai anak dua dan mengikuti program pemerintahtetapi kedua-duanya gagal meraih gelar sarjana, akhirnya terjerumus ikut merampok. Hal ini suatu kenyataan bahwa siapa saja yang telah mengabaikan ungkapan budaya Jawa, jelas akan gagal membina putra-putrinya.

\section{g. Sifat Gemi}

Para orang tua dalam budaya Jawa, selalu menasihati putra--putrinya untuk bersikap gemi artinya pandai menghemat. 
Pada dasarnya gemi adalah selalu memperhitungkan secara cermat untuk mengeluarkan uang. Pengertian gemi atau hemat pengeluaran bukanlah pelit melainkan dapat membedakan apa yang perlu dibeli dan apa yang belum perlu dibeli. Sedangkan pelit adalah tidak mau memberi bantuan berupa uang meskipun sangat diperlukan, padahal kaya. Seseorang yang mempunyai sifat gemi, bila orang lain memang perlu ditolong, ia dengan rela dan senang hati memberi bantuan uang dan tidak mengha-rapkan sesuatu. Seseorang yang mempunyai sifat pelit, sulit dimintai bantuan keuangan untuk seseorang yang sangat membutuhkan, meskipun ia kaya. Kita memang perlu gemi agar kita tidak memenuhi kesulitan dalam kehidupan. Gemi berarti dapat mengatur keseimbangan antara pendapatan dan pengeluaran uang. Namun kita sering terpengaruh lingkunganyang majemuk yang mengarah kepada hidup boros atau dalam bahasa Jawanya moto sehingga nasihat para sesepuh untuk hidup gemi telah luntur. Akibatnya menyusahkan diri sendiri. Sifat gemi memang perlu dimiliki oleh siapa pun karena sifatnya universal. Pengertian moto adalah seseorang yang senang memberi uang kepada orang lain, meskipun tidak dimiliki dan mungkin tidak dibutuhkan. Hal ini adanya kemungkinan bahwa seseorang yang memiliki sifat gemi juga mudah mengeluarkan uang dan menjadi 
dermawan, apabila hal tersebut memang diperlukan untuk membantu kesulitan orang yang sangat perlu mendapatkan bantuan.

h. Sifat Nastiti

Nastiti artinya cermat yaitu segala tindakan yang akan dilakukan perlu dipertimbangkan masak-musak. Ungkapan itu selalu diajarkan oleh para orang tua terhadap putra-putrinya, terutama bila mereka telah meningkatdewasa. Sekarang sejauh mana orang Jawa masih mengingat, pesan atau ajaran orang tua mengenai ungkapan tersebut. Sifat cermat bagi seseorang adalah merupakan dasar agar tugas yang dikerjakannya berhasil dengan baik dan memuaskan, baik untuk orang yang memberi pekerjaan maupun diri sendiri. Nastiti atau cermat dapat diartikan pula bahwa kita selalu cepat mengetahui kesalahan yang kita buat. Oleh karena itu sikap nastiti perlu ditanamkan sejak kecil di dalam lingkungan keluarga inti. Orang cermat selalu mengadakan perhitungan-perhitungan segala sesuatu yang akan dikerjakan. Maksudnya selalu waspada agar tidak terperosok di dalam jurang kesengsaraan.

i. Sifat Ngati-ati

Ngati-ati arti dalam bahasa Indonesia adalah selalu berhati-hati. Apa yang dilakukan perlu dipikirkan terlebih dahulu. 
Jika sekiranya telah memutuskan sesuatu harus dilakukan, maka dalam melaksanakan keputusan harus berhati-hati. Seseorang dapat berhati-hati bila seseorang didasari oleh sifat nastiti seperti telah diuraikan. Berhati-hati merupakan sikap dewasa, artinya segala apa yang dilakukan jangan sampai menim-bulkan konflik. Untuk itu diperlukan adanya tenggang rasa, dan tidak lupa berdoa kepada Tuhan Yang Maha Esa. Saling menghargai dan menghormati dan adanya pengendalian diri agar kita tidak kehilangan kontrol. Budaya ngati-ati selalu disampaikan oleh orang tua bila anak-anaknya akan melakukan atau melaksanakan kegiatan. Budaya ngati-ati biasanya dilengkapi dengan kata-kata sing eling, artinya agar selalu ingat petuah orang tua dan Tuhan. Lebih lengkap lagi bila ungkapan itu ditambah waspada sehingga berbunyi ngati-ati, sing eling lan waspada, agar tidak terjadi apaapa yaitu agar nir ing sambe kala artinya bebas dari gangguan dan hambatan. Dengan ungkapan itu, orang tua selalu mengharapkan agar putra-putrinya dapat sukses dalam menempuh kehidupan. Jadi ungkapan gemi, nastiti, ngati-ati membawa misi agar kita dalam menempuh kehidupan selalu sukses dengan gemilang tanpa rintangan apapun.Kita berpalingpada ungkapan itu, agar kita dapat selamat sampai di akhirat.

j. Jer Basuki Mawa Beya 
Arti ungkapan tersebut di atas adalah bila kita ingin berhasil perlu dan haruss mengeluarkan biaya, agar kita berhasil dalam segala usaha. Bagi masyarakat Jawa adalah wajar bila harus mengeluarkan uang. Hakikat dari ungkapan Jer Basuki Mawa Beya adalah, segala sesuatu yang kita cita-citakan harus disertai dengan usaha sungguh-sungguh di samping diperlukan biaya sehubungan dengan hal tersebut, orang Jawa tidak sayangsayang untuk mengeluarkan uang, asal apa yang dimaksudkan dapat terwujud, meskipun uang itu diperoleh dengan cara menjual apa saja yang dimilikinya atau dengan meminjam uang yang disertai bunga tinggi. Hal ini tercermin bila orang Jawa ingin mendapatkan pekerjaan sehingga sering kali mudah tertipu dengan janji-janji muluk, seolah-olah meyakinkan. Akhirnya kecewa, karena apa yang diharap-harapkan tidak pernah menjadi kenyataan. Dengan demikian dalam mengartikan ungkapan Jer Basuki Mawa Beya perlu diluruskan, yaitu bahwa aplikasi ungkapan ini adalah, bila kita ingin mencapai apa yang dicitacitakan hams disertai usaha yang sungguh-sungguh, bekerja giat penuh semangat. Untuk mendapatkan pendidikan yang berkualitas perlu biaya yang cukup tinggi juga disertai belajar dengan tekun, sungguh-sungguh.

k. Ajining Dhiri Saka Obahing Lathi 
Ungkapan ini sudah jarang didengar, dan sudah banyak yang melupakan. Arti dari ungkapan itu adalah harga diri seseorang itu tergantung dari apa yang dikatakan. Maksudnya tidak asal menggerakkan bibir saja, (obahing lathi) atau asal omong saja, tetapi apa yang diucapkan melalui bibir perlu dipertimbangkan baik-baik. Bila kita berbicara melalui gerakan bibir harus dengan kata-kata yang sopan, hormat dan dapat menyenangkan orang lain. Yang terang orang akan dihargai karena ucapannya yang baik, laras dan konsekuen yaitu apa yang diucapkan harus dilaksanakan. Janji harus ditepati, bila tidak orang lupa, karena kedudukan atau jabatan. Saking orang lupa, karena kedudukan atau jabatan, sehingga bila berbicara asal bicara, asal menjawab, asal keluar suara sampai-sampai yang diucapkan akan menimbulkan akibat fatalnya,bicaranya menyakitkan hati, kasar, kotor, sehingga menyinggung harga diri orang. Akibatnya menimbulkan pertengkaran sampai terjadi saling baku hantam. Akhirnya bencana kematian terjadi hanya karena kata-kata yang dikeluarkan melalui bibir tidak terkendalikan. Untuk itulah kita perlu berhati-hati bila kita berbicara. Sedapat mungkin menghindari kata-kata yang menyinggung perasaan orang lain. Jika seseorang menduduki jabatan tinggi, bila berbicara di dalam forum umum perlu 
menggunakan teks agar sebelum disampaikan dapat diteliti terlebih dulu, agar apa yang disampaikan tidak menimbulkan masalah.

\section{Pendidikan karakter bersumber kearifan lokal}

Dari nilai-nilai luhur seperti: Aja Dumeh, Tepa selira, Mawas Diri, Luhur, Sikap Utama, Sikap Gugontuhon, Sikap Wani Tombok, Mendhem Jero Mikul Dhuwur maka kita dapat menerapkanya pada pendidikan untuk membentuk karakter.Prof. Dr. Cece Rakhmat, M.Pd menjelaskan untuk menanamkan karakter pada anak terdapat pada tiga tahap, Pertama kognitif, mengisi otak, mengajarinya dari tidak tahu menjadi tahu, dan pada tahap-tahap berikutnya dapat membudayakan akal pikiran, sehingga dia dapat memfungsi akalnya menjadi kecerdasan intelegensia. Kedua, afektif, yang berkenaan dengan perasaan, emosional, pembentukan sikap di dalam diri pribadi seseorang dengan terbentuknya sikap, simpati, antipati, mencintai, membenci,dan lain sebagainya. Sikap ini semua dapat digolongkan sebagai kecerdasanemosional. Ketiga, psikomotorik, adalah berkenaan dengan aktion, perbuatan,prilaku, dan seterusnya. Hal itu juga sependapat dengan apa yang dikatakan Lickona (1991) untuk memiliki 
karakter yang baik maka seseorang harus menguasai tiga kompetensi yakni moral knowing, moral feeling dan moral actionserta Ki Hajar Dewantoro "ngerti-ngerasa-ngelakoni" (menyadari, menginsyafi dan melakukan).Untuk menanamkan ketiga ranah karakter (pengetahuan, perasaan dan tindakan) pada anak, maka sekolah dapat melakukanya dengan empat metode seperti penanaman nilai, keteladanan nilai, fasilitasi nilai, dan keterampilan (Kirschenbaum, 1995:6).

\section{Tujuan Pendidikan Nasional}

Sebagaimana tercantum dalam UU No.20 Tahun 2003 tentang Sistem Pendidikan Nasional, pendidikan nasional adalah pendidikan yang berdasarkan Pancasila dan Undang-Undang Dasar Negara Republik Indonesia Tahun 1945 yang berakar pada nilai-nilai agama, kebudayaan nasional Indonesia dan tanggap terhadap tuntutan perubahan zaman Pasal 1 (2). Pendidikan nasional berfungsi mengembangkan kemampuan dan membentuk watak serta peradaban bangsa yang bermartabat dalam rangka mencerdaskan kehidupan bangsa, bertujuan untuk berkembangnya potensi peserta didik agar menjadi manusia yang beriman dan bertakwa kepada Tuhan Yang Maha Esa, berakhlak 
mulia, sehat, berilmu, cakap, kreatif, mandiri, dan menjadi warga negara yang demokratis serta bertanggung jawab (Pasal 3).

Dari paparan di atas, tujuan pendidikan nasional memuat berbagai nilai kemanusiaan yang harus dimiliki segenap warga negara Indonesia. Nilai tersebut merupakan sumber operasional dalam pengembangan pendidikan budaya dan karakter bangsa bagi seluruh warga Negara Indonesia guna mewujudkan generasi bangsa yang mampu mempertahankan eksistensinya dalam persaingan global. 


\section{BAB VI}

\section{FAKTOR-FAKTOR YANG MEMPENGARUHI KARAKTER}

Para ahli mengelompokkan faktor yang mempengaruhi karakter ke dalam dua bagian, yaitu faktor internal dan eksternal.

\section{A. Faktor Internal}

1. Insting atau naluri

Manusia sebelum melakukan setiap perbuatan atau aktifitas pastinya akan digerakkan oleh insting/ naluri. Setiap manusia yang lahir ke dunia dibekali oleh Allah Swt. dengan insting/ naluri. Dampak insting/ naluri pada diri manusia tergantung kepada penyalurannya. Naluri dapat menjerumuskan manusia pada kehinaan, tetapi dapat juga mengangakat kepada derajat yang tinggi, jika naluri disalurkan kepada hal baik dengan tuntunan kebenaran (Gunawan, 2014). Insting atau naluri bekaitan erat dengan akal manusia, sehingga tidaklah salah bahwa makhluk paling sempurna ciptaan Allah adalah manusia yang mempunyai akal dan nafsu.

2. Kebiasaan atau adat

Salah satu faktor penting dalam tingkah laku manusia adalah kebiasaan, karena sikap dan perilaku yang menjadi akhlak (karakter) sangat erat sekali dengan kebiasaan. Kebiasaan adalah perbuatan yang selalu diulang-ulang sehingga mudah untuk 
dikerjakan (Gunawan, 2014) Kebiasaan baik atau jelek sangat berpengaruh kepada terbangunnya akhlak manusia, seperti halnya air dengan minyak, kebiasaan berbuat jelek tidak bisa bersatu dengan kebiasaan berbuat baik.

3. Kemauan atau kehendak

Kemauan adalah salah satu kekuatan yang berlindung dibalik tingkah laku dan merupakan kekuatan yang mendorong manusia dengan sungguh sungguh untuk berperilaku (berakhlak), sebab dari kehendak itulah menjelma suatu niat yang baik dan buruk. Kemauan mampu melangsungkan segala ide (Gunawan, 2014). Kehendak atau kemauan tidak akan bisa terlepas dengan niat. Seperti halnya melakukan ibadah bisa menghasilkan pahala atau tidak ketika niat tidak sesuai perintah Allah.

4. Suara hati atau suara batin

Di dalam diri manusia terdapat suatu kekuatan yang sewaktuwaktu memberikan peringatan (isyarat), jika tingkah laku manusia berada diambang bahaya dan keburukan, maka kekuatan tersebut adalah suara batin atau suara hati. Suara batin berfungsi memperingatkan bahaya perbuatan buruk dan berusaha mencegahnya, di samping dorongan untuk melakukan perbuatan baik (Zubaedi, 2012). Suara hati atau batin biasanya bersih, ketika seseorang akan melakukan perbuatan jahat sebenarnya di dalam hatinya atau batinnya mengatakan bahwa perbuatan itu tercela, akan tetapi berhubung ada setan, manusia pun lebih mengikuti tergoda akan tipu dayanya.

\section{Keturunan}

Keturunan merupakan suatu faktor yang dapat mempengaruhi perbuatan manusia. Adapun sifat yang diturunkan orang tua 
terhadap anaknya itu bukan sifat yang tumbuh dengan matang karena pengaruh lingkungan, adat, dan pendidikan, melainkan sifat-sifat bawaan sejak lahir (Zubaedi, 2012). Keturunan yang baik berasal dari orangtua yang baik juga, sehingga di dalam Islam terdapat ajaran agar menikah dengan memperhatikan akhlaknya, kecantikan, dan hartanya.

\section{B. Faktor Eksternal}

1. Pendidikan

Pendidikan mempunyai pengaruh yang sangat besar dalam pembentukan karakter seseorang. Pendidikan ikut mematangkan kepribadian manusia sehingga tingkah lakunya sesuai dengan pendidikan yang telah diterima seseorang baik pendidikan formal, informal, maupun nonformal. Betapa pentingnya faktor pendidikan itu, karena naluri yang terdapat pada seseorang dapat dibangun dengan baik dan terarah (Gunawan, 2014). Pendidikan adalah investasi seseorang dimasa depan, khususnya investasi orangtua kepada anak-anaknya, ketika pendidikan seorang anak salah maka hasilnya akan mengecewakan, tapi jika pendidikan seorang anak baik niscaya akan membahagiakan kepada orangtuanya.

\section{Lingkungan}

Salah satu aspek yang turut memberikan saham dalam terbentuknya corak sikap dan tingkah laku seseorang adalah faktor lingkungan di mana seseorang berada. Lingkungan artinya sesuatu yang melingkupi tubuh yang hidup, meliput tanah, udara, sedangkan lingkungan manusia adalah apa yang melingkupi manusia dalam arti seluas-luasnya (Muslich, 2011). Lingkungan 
juga mengambil peran penting dalam pembangunan karakter, seorang anak hidup dalam lingkungan pondok-pesantren pasti akan berbeda dalam hal pengetahuan agamanya jika dibandingkan dengan anak yang hidup dalam lingkungan prostitusi.

\section{Tantangan-Tantangan Pendidikan Karakter}

Dengan mengacu pada taksonomi Bloom, maka pendidikan karakter pada dasarnya termasuk pendidikan pada ranah efektif. Sebagaimana nasib pendidikan afektif selama ini yang hanya berhenti pada retorika saja, maka pendidikan karakter ke depan juga akan menghadapi tantangan yang tidak ringan, baik tantangan yang bersifat internal maupun eksternal.

Tantangan yang bersifat internal dapat berupa orientasi pedidikan kita selama ini yang masih mengutamakan aspek keberhasilan bersifat kognitif, praksis pendidikan yang masih banyak mengacu filsafat rasionalisme yang memberikan peranan yang sangat penting bagi kemampuan akal budi (otak) manusia, kemampuan dan karakter guru yang belum mendukung, serta budaya dan kultur sekolah yang kurang mendukung.

Sementara itu tantangan yang bersifat ekternal adalah pengaruh globalisai, perkembangan sosial masyarakat, dan pengaruh perkembangan teknologi informasi dan komunikasi.

1. Tantangan Internal

Proses pendidikan di sekolah kita sampai saat ini ternyata masih lebih mengutamakan aspek kognitif dan psikomotoriknya dibandingkan afektifnya. Model evaluasi Ujian Nasional pun 
banyak dinilai lebih mementingkan aspek intelektualnya daripada aspek kejujurannya. Konon tingkat kejujuran Ujian Nasional saat ini hanyalah 20\%, karena masih banyak peserta didik yang menyontek dalam berbagai cara dalam mengerjakan soal Ujian Nasional tersebut.

Kabar yang lebih mengejutkan lagi adalah bahwa banyak kecurangan oleh peserta Ujian Nasional tersebut dikoordinir dan mendapat restu dari guru dan kepala sekolahnya. Hal ini sengaja dilakukan karena alasan keamanan kedudukan kepala sekolahnya, sebab jika banyak siswa yang tidak lulus bisa jadi kepala sekolahnya akan mendapat sanksi dari kepala dinas atau bupati/walikotanya (Suparlan, 2010).

Guru merupakan stakeholders yang sangat menentukan keberhasilan dalam proses pendidikan di sekolah. Sebagaimana dikutip oleh Kyle (1985), menyatakan bahwa salah satu indikator dari keberhasilan pendidikan di sekolah adalah mutu pencapaian hasil belajar siswanya, dan hasil belajar siswa tersebut sangat tergantung pada sejauh mana keberhasilan guru dalam membantu siswa untuk mencapai hasil belajaranya.

Dalam hal ini apa yang dipelajari siswa selama di sekolah banyak bergantung pada apa yang terjadi di kelas, dan apa yang terjadi di kelas sangat bergantung pada bagaimana prakarsa guru yang mengimplementasikan kurikulum dan rencana pembelajaran ke dalam kegiatan belajar di kelas. Dalam menuangkan kurikulum menadi kegiatan belajar-mengajar siswa aktual, dan menentukan cara bagaimana siswa harus mempertanggung- jawabkan hasil belajarnya. 
Demikian pula pendidikan karakter tidak membutuhkan toeri berlebihan tetapi lebih diutamakan adalah praktik atau manifestasi nilai-nilai luhur tersebut di dalam kehidupan seharihari. Untuk iti guru dituntut untuk memberikan praktik dan contoh yang baik kepada siswa, sehingga guru adalah seorang motivator dan sekaligus menjadi seorang teladan bagi siswasiswanya.

Seorang guru selain dituntut harus mempunyai kompetensi pedagogis sebagai basic pembelajaran, guru juga harus mempunyai beberapa kompetensi utama dalam melakukan proses pembelajaran dalam pendidikan karakter.

Kompetensi pertama adalah kompetensi kepribadian, yaitu menjadi guru yang berkepribadian baik, santun, serta mengembangkan sifat terpuji sebagai seorang guru. Pendidikan karakter membutuhkan guru yang dapat memberikan nilai yang dapat langsung memberikan dicontoh oleh siswa.

Kompetensi kedua adalah kompetensi untuk berinteraksi dan berkomunikasi. Guru harus dapat membangun hubungan yang baik dengan siswa, tanpa menghilangkan sopan santun antara guru dan murid, sudah menadi kewajiban guru untuk menjalin hubungan yang harmonis dengan siswanya. Melakukan pendekatan yang persuasive untuk meningkatkan motivasi dalam belajar. Mampu memberikan konsep belajar-mengajar yang tidak menekan dan memaksa terhadap murid. Serta memberi sanksi yang sesuai dan konstruktif jika siswa melakukan kesalahan. Dan yang paling urgen adalah tidak ada legitimasi bagi guru untuk melakukan kekerasan terhadap siswa apapun alasannya, untuk kekerasan fisik maupun psikis. 
Kompetensi ketiga adalah kompetensi bimbingan dan penyuluhan. Dalam teori tabularasa siswa yang digambarkan sebagai sebuah kertas putih yang masih bersih yang nanti akan diisi dengan catatan-catatan kehidupan. Oleh karena itu guru harus selalu memberikan bimbingan di dalam pengisian kertas putih ini. Seorang siswa akan membutuhkan bimbingan dari orang lain dalam menjalani kehidupannya yang semakin kompleks. Di sekolah-sekolah pada umumnya sudah banyak memiliki guru BK (Bimbingan Konseling), akan tetapi kebanyakan di lapangan justru siswa menauhi guru BK karena merasa takut dengan image guru BK. Kompetensi bimbingan dan penyuluhan seharusnya dimiliki oleh setiap guru, tidak hanya guru BK, karena dimungkinkan seorang siwa akan merasa lebih nyaman dengan salah satu guru tertentu daripada guru BK.

Selain tantangan-tantangan tersebut di atas, pendidikan karakter di sekolah akan dihadapkan pada masih dominannya pemikiran filsafat rasionalisme dalam mewarnai praksis pendidikan di sekolah (Tilaar, 2002). Filsafat rasionalisme memberikan peranan yang sangat penting kepada kemampuan akal budi (rasio) manusia. Keberadaan manusia ditentukan karena rasionya. Tanpa akal eksistensi manusia akan lenyap.

Pengaruh rasionalisme di dalam praksis pendidikan dan kehidupan umat manusia terutama dapat kita lihatdi Eropa Barat pada abad pertengahan, yang telah mendewakan kemampuan akal manusia sebagai kemampuan tanpa batas. Akal (rasio) dianggap ,merupakan sumber kebenaran. Alam semesta dan realitas akan dapat dipahami oleh manusia tanpa ketergantungan pada pengamatan dan pengalaman empiri. Akal budi manusia 
merupakan sumber ilmu pengetahuan dan sumber nilai, termasuk nilai-nilai moral, efisiensi, kegunaan, dan semuanya merupakan ukuran dari filsafat rasionalisme.

Sumber pengetahuan adalah kemampuan akal yang secara dedukatif tetapi konsekuen dan logis dapat menguasai segala sesuatu tanpa perlu pemikiran induktif tetapi konsekuen dan logis yang dapat menguasai segala sesuatu tanpa perlu pemikiran induktif berdasarkan pengalaman empiri. Pemikiran pendidikan yang sejalan dengan filsafat rasionalisme adalah mengembangkan akal manusia untuk menguasai dunia, penguasaan alam, bahkan tujuan kehidupannya. Rasionalisme pada akhirnya memproklamirkan bahwa Tuhan itu tidak ada.

Selain itu perkembangan praksis pendidikan di Indonesia pada orde lama dan orde baru ternyata masih sangat mewarnai praksis pendidikan kita saat ini. Pada masa orde lama sesuai dengan perkembangan politik tanah air, telah lahir orientasi pendidikan kearah etatisme dan nasionalisme yang sempit. Di era tersebut pendidikan telah menjadi bagian dari politik praktis. Filsafat pendidikan telah digantikan dengan ideologi pendidikan yang bersumber dari ideologi Negara. Dengan sendirinya, proses pendidikan merupakan proses indoktrinasi yang tidak memberikan tempat kepada kreativitas dan kebebasan berpikir manusia.

Pada era orde baru pada hakekatnya masih melanjutkan orientasi pedagogic orde lama demi untuk pembangunan. Pendekatan pembangunan melahirkan orientasi developmentalisme, yaitu proses pendidikan yang diarahkan kepada percepatan pembangunan, tanpa melihat 
fundamenfundamen pendidikan yang hakiki. Orientasi pendidikan diarahkan pada pencapaian target dan bukan kepada pengembangan manusia itu sendiri atau dehumanisasi. Dengan orientasi developmentalisme, dan usaha pencapaian target-target, maka telah mengarahkan orientasi pendidikan yang dehumanisasi.

Pada orde reformasi, masyarakat Indonesia masih berada pada masa transisi. Orientasi pendidikan pada era orde lama dan orde baru terasa masih tetap eksis. Mengubah suatu sistem pendidikan yang berorientasi dehumanisasi, memerlukan waktu yang panjang.

Berdasarkan pengembangan praksis pendidikan tersebut, maka menurut Pilliang (Tilaar, 2002), profil manusia Indonesia saat ini telah mengalami proses dehhumanisasi yang diakibatkan oleh orientasi pendidikan. Pada masa orde lama, telah menghasilkan "manusia ideology", orde era reformasi telah menghasilkan manusia-manusia komoditi yang bersedia dibayar untuk demonstrasi, karnavalisme, retorika, pawai unjuk rasa, juga menjadikan manusia yang suka memisahkan diri, sparatisme dan lain-lain. Oleh karena itu, manusia Indonesia perlu direhumanisasi karena telah kehilangan kemanusiannya.

Dalam Grand Design pendidikan karakter di sekolah yang dikembangkan oleh Kemendiknas (2010), dinyatakan bahwa pendidikan karakter merupakan proses pembudayaan dan pemberdayaan peserta didik agar memiliki nilai-nilai luhur dan perilaku yang berkarakter. Yang dapat dilakukan melalui integrasi nilai-nilai luhur dalam pembelajaran, melalui program pengembangan diri dalam kegiatan-kegiatan ekstrakulikuler, dan 
dimanifestasikan ke dalam tata pergaulan dan budaya sekolah Ketiga jalur pendidikan nilai-nilai luhur tersebut tidakboleh saling kontradiksi tetapi harus searas dan saling memperkuat.

Integrasi nilai-nilai luhur ke dalam kegiatan pembelajaran di kelas dan dalam program pengembangan diri melalui kegiatan ekstra kulikuler pada umumnya dapat direncanakan secara terprogram dan terukur hasilnya. Namun implementasi atau manifetasi nilai-nilai luhur dalam tata pergaulan dan kultur/budaya sekolah pada umumnya sulit terukur hasilnya. Di lain pihak, budaya/kultur sekolah bukanlah keadaan yang dapat diciptkan secara tiba-tiba, tetapi merupakan hasil kristalisasi nilai-nilai yang menjadi keyakinan dan milik bersama, yang menjadi pengikat kuat kebersamaan mereka sebagai warga suatu masyarakat sekolah (Deal dan Peterson, 1999).

Sementara itu, pengertian lain tentang kultur sekolah diajukan oleh Schein (1992), bahwa kultur sekolah adalah suatu pola asumsi dasar hail invensi, penemuan atau pengembangan oleh suatu kelompok tertentu pada saat dia belajar dan berhasil dalam mengatasi masalah-masalah serta dianggap valid, dan akhirnya diajarkan kepada warga baru sebagai cara-cara yang benar dalam memandang, memikirkan, dan merasakan masalahmasalah tersebut.

\section{Tantangan Eksternal}

Gelombang globalisasi bukan hanya mengubah tatanan kehidupan global, tetapi juga telah mengubah tatanan kehidupan pada tingkat mikro. Pengaruuh globalisasi di dalam ikatan kehidupan social dapat bersifat positif, tetapi dapat juga bersifat 
negative. Salah satu dampak negative dari proses globalisasi adalah kemungkinan terjadinya disintegrasi social. Beberapa gejala transisi social akibat globalisasi antara lain adalah hilangnya tradisi. Dalam hal ini, bentuk-bentuk budaya global telah memasuki segala segi kehidupan social ditingkat mikro, sehingga dikhawatirkan bahwa nilai-nilai tradisi dan nilai-nilai moral yang hidup di masyarakat semakin lama semakin terkikis.

Gelombang globalisasi yang ditunjang dengan perkembangan teknologi informasi dan komunikasi telah menghancurkan batasbatas waktu dan mengubah tata pergaulan umat manusia. Bahkan pengertian mengenai Negara-negara mulai berubah. Dimana-mana lahirlah bentuk nasionalisme baru yang dikenal sebagai etnonasionalisme atau bentuk Negara post nation state. Terdapat kecenderungan berkembangnya sentiment nasional yang beralih kepada sentiment primordial baik dalam bentuk budaya, ras, agama. Perkembangan yang baru ini tentunya memberikan pengaruh terhadap system pendidikan yang dikenal dewasa ini.

Memang disadari etno-nasionalisme dapat menjurus kepada sentiment sukuisme yang eksklusif. Tentu ini berbahaya bagi persatuan nasional. Masyarakat dan bangsa Indonesia yang teriri atas kelompok-kelompok etnis dari yang beranggotakan jutaan sampai kelompok kecil yang beranggotakan ratusan orang, semuanya mempunyai kebudayaan sendiri.

Diakui bahwa banyak factor yang mempengaruhi merosotnya nilai-nilai moralitas dlam tata kehidupan kolektif sebagai bangsa. Hal ini terjadi akibat perubahan system politik pasca reformasi yang menimbulkan euphoria politik berlebihan, 
kebebasan berdemokrasi yang nyaris tanpa batas, sampai mengabaikan nilai-nilai etika. Selain itu pesatnya perkembangan teknologi informasi dan komunikasi yang membuat arus informsai begitu derass. Nyaris taka da lagi filter untuk memilih dan memilah. Norma-norma agama atau budaya nyaris tak mampu membendung informasi yang mendorong terjadinya degradasi moral. Apalagi norma hokum dan peraturan perundang-undangan mudah dibongkar-pasang, didekonstruksi dan direkonstruksi sesuai dengan kepentingan tertentu.

\section{Pendidikan Karakter di Era Digital}

Zaman serba teknologi ini menjadikan anak telihat sangat pasif dan jarang untuk bersosialisasi di keluarga maupun masyarakat. Kebanyakan anak zaman sekarang lebih fokus untuk memperhatikan layar di depan matanya dibandingkan bermain dengan teman sebayanya. Sehingga tak jarang anak kehilangan waktu berharganya bermain bersama keluarga, belajar, mengembangkan bakat atau bermain bersama teman-temannya karena fokusnya sudah diambil alih oleh layar ponsel ataupun teknologi yang ada.Disini peran orangtua sangat penting dalam membimbing, memantau, serta mengatur waktu anak dari alat digital yang dipakai.

Adapun yang harus dilakukan orang tua terhadap anak dalam pengasuhan digital atau digital parenting adalah sebagai berikut:

1. Meningkatkan dan memperbarui wawasan tentang internet dan gadget. Orang tua tidak bisa mengawasi anak-anak apabila orang tua gagap teknologi. 
2. Jika di rumah ada internet, posisikan di ruang keluarga dan siapa yang dapat melihat apa yang dilakukan anak dalam mengakses internet.

3. Membatasi waktu pada anak dalam menggunakan gadget dan internet.

4. Memberikan pemahaman dan kesadaran bersama akan dampak negative dari internet atau gadget.

5. Secara tegas melarang sesegera mungkin jika ada yang tidak pantas ditonton

6. Menjalin komunikasi yang terbuka dua arah dengan anak-anak.

Anak-anak era digital telah banyak dimanjakan dengan teknologi yang serba canggih, seperti mencari bahan pembelajaran melalui situs Google, permainan tradisional sudah banyak ditinggalkan. Ciri-ciri Generasi Digital adalah sebagai berikut:

1. Generasi digital ramai-ramai membuat akun di media sosial untuk membuktikan kepada dunia bahwa mereka ada.

2. Generasi digital cenderung lebih terbuka, blak-blakan, dan berfikit lebih agresif.

3. Generasi digital cenderung ingin memperoleh kebebasan. Mereka tidak suka diatur dan dikekang. Mereka ingin memegang kontrol dan internet menawarkan kebebasan berekspresi.

4. Generasi digital selalu mengakses dengan Google, Yahoo, atau situs lainnya. Kemampuan belajar mereka jauh lebih cepat karena segala informasi ada di ujung jari mereka.

Sebagai seorang pendidik dan seorang orang tua, harus menjadi panutan dan rolemodel yang baik untuk anak demi membentuk 
kepribadian dan karakter yang baik. Apalagi di era digital ini sangat mudah untuk menggali dan mendapatkan informasi di internet.Sebagai pendidik ataupun orang tua sudah seharusnya menjadi pengawas dan pembimbing yang baik untuk anak-anak dalam mendapatkan infromasi. Apalagi usia anak-anak sekolah dasar yang masih belum mampu membedakan dengan baik mana hal yang baik dan mana hal yang buruk. Dikahawatirkan, dengan teknologi yang ada, anak-anak justru terkena dampak negatif dari teknologi itu sendiri karena kurangnya pantauan pendidik maupun orangtua. Dini (2018) menyebutkan dampak positif dan negative dari teknologi digital, sebagai berikut:

\section{a. Dampak Positif}

1) Sarana penyampaian informasi, informasi suatu kejadian secara cepat, tepat dan akurat

2) Mempermudah akses terhadap informasi baru, memperoleh informasi kapanpun dan dimanapun.

3) Media sosial, mempertemukan individu dengan orang yang baru, mempertemukan individu dengan teman lama yang jarang sekali bertemu, saran berbisnis.

4) Membantu dalam mencari informasi bahan pelajaran bagi peserta didik.

5) Media hiburan.

6) Sebagai eksistensi seseorang dalam media sosial.

7) Mempermudah komunikasi meskipun dalam keadaan jarak yang jauh.

\section{a. Dampak Negatif}


1) Anak bersifat Individual, berkurangnya tingkat pertemuan langsung atau interksi antar sesama manusia.

2) Temperamen, kebiasaan bersosialisasi dengan media sosial, maka anak akan beranggapan bahwa dunia luar adalah ancaman.

3) Berita tanpa tanggung jawab, berita Hoax, Bulying.

4) Rentannya kesehatan mata, terutama mengalami rabun jauh atau rabun dekat.

5) Tak bisa menikmati hidup. Ketika menghadiri sebuah acara pesta, kita malah asik berfoto, tanpa menimati acara pesta dan musik.

6) Radiasi alat hasil teknologi membahayakan kesehatan otak anak.

7) Maraknya kasus penipuan lewat sms, telepon dan internet.

8) Mudahnya mengakses video porno.

9) Anak lupa akan pekerjaan rumah yang ditugaskan oleh guru dan lupa melaksanakan ibadah, seperti sholat dan mengaji.

10) Anak menjadi sasaran kejahatan, seperti penculikan anak dan pemerkosaan anak.

Contoh kasus yang paling banyak dan marak terjadi adalah bullying dimana dampaknya sangat berpengaruh pada korban.Dampaknya bukan hanya jangka pendek melainkan jangka panjang bahkan bisa terbawa sampai korban melanjutkan pendidikan ke jenjang sekolah yang lebih tinggi.Dampak bullying sendiri membuat korban menjadi minder, tidak percaya diri, cenderung menutup diri dari lingkungan sosial, menyakiti diri sendiri atau paling parahnya lagi ialah memiliki hasrat untuk bunuh diri.

Selain bullying, situs pornografi merupakan salah satu dampak negative dari teknologi yang ada.Kemudahan dalam mengakses 
dan menyebarkan video secara digital ternyata masih banyak yang disalahgunakan.Apalagi, pemerintah sendiri tidak untuk membatasi akses situs pornografi yang ada di internet.Hal-hal seperti ini yang menjadikan banyaknya anak bangsa yang karakternya masih cenderung buruk. Maka dari itu pengawasan dari orangtua dan pendidik sangat diperlukan untuk memantau apa yang anak lakukan dengan gadgetnya demi berkembangnya karakter anak menjadi lebih baik. Lagipula, anak pada usia sekolah dasar memang seharusnya menggunakan waktunya untuk berkumpul keluarga, bermain bersama teman, bersosialisasi untuk mengasah keterampilan sosialnya dibandingkan menghabiskan waktu dengan gadgetnya hanya untuk bermain video game dan sejenisnya.

\section{E. Tantangan Dalam Implementasi di Sekolah}

Secara konseptual, pendidikan karakter di sekolah tampaknya sudah cukup mapan. Namun dalam pelaksanaannya, hal itu akan mendapat tantangan yang sangat besar. Tantangan tersebut dapat berasal dari lingkungan pendidikan itu sendiri maupun dari luar. Tantangan dari dalam dapat berasal dari personal pendidikan maupun perangkat lunak pendidikan (mind set, kebijakan pendidikan dan kurikulum). Tantangan dari luar berupa perubahan lingkungan sosial secara global yang mengubah tata nilai, norma, dan budaya suatu bangsa, menjadi sangat terbuka. Perubahan itu tidak dapat dikendalikan dan dibatasi karena berkembangnya teknologi informasi 
1. Tantangan Dalam Kebijakan Dan Kurikulum

Karakter merupakan produk yang berupa pengetahuan, sikap dan perilaku yang ditunjukkan oleh sesorang. Bila pendidikan karakter ini hanya bertumpu pada sekolah maka akan gagal. Kegagalan terjadi karena secara kuantitas dan kualitas, sekolah (khususnya di Indonesia) belum merupakan lingkungan yang dominan dalam kehidupan anak. Hanya sedikit bagian waktu dalam kehidupannya, anak berada dalam lingkungan dan situasi sekolah. Interaksi yang terjadi antara guru dan siswa masih sangat terbatas pada jam-jam pelajaran. Belum ada situasi dan kesempatan yang memungkinkan peserta didik dan sekolah berinteraksi di luar jam pelajaran. Kebanyakan waktu anak adalah dalam keluarganya, sehingga keluarga seharusnya berkesempatan lebih banyak untuk mendidik anak-anaknya walaupun Daniel Goleman mengatakan bahwa banyak orang tua yang gagal dalam mendidik karakter anak-anaknya. Kegagalan dikarenakan kesibukan atau lebih mementingkannya aspek kognitif anak. Semua ini dapat dikoreksi dengan memberikan pendidikan karakter di sekolah

Pendidikan karakter di sekolah sangat diperlukan, walaupun dasar dari pendidikan karakter adalah di dalam keluarga. Bila seorang anak mendapatkan pendidikan karakter yang baik dari keluarganya, diharapkan anak tersebut seterusnya akan berkarakter baik. Namun, seperti sinyalemen Daniel Goleman di atas, ternyata banyak orang tua yang lebih mementingkan aspek kecerdasan otak ketimbang pendidikan karakter. 
Pendidikan karakter di sekolah tidak cukup dengan memberikan mata pelajaran budi pekerti dalam struktur kurikulum. Pemberian mata pelajaran budi pekerti atau pendidikan moral bukan merupakan bagian yang dinilai dalam pendidikan karakter. Pemberian mata pelajaran hanya menkualifikasikan pemahaman secara teoritis. Tidak ada kaitan logis bahwa penilaian dalam mata pelajaran budi pekerti (agama, Pkn atau sejenisnya) menentukan kualitas kepribadian siswa (Doni Kusuma, 2007: 182-283). Lickona (1991:162-163). menyatakan pentingnya pendidikan karakter terintegrasi dalam kurikulum dengan pernyataan Kita akan menyianyiakan kesempatan besar, jika kita keliru dalam memanfaatkan kurikulum sebagai kendaraan dalam mengembangkan nilai-nilai dan kepedulian terhadap etika. Bahkan, Lickona menganggap kurikulum seakan raksasa yang sedang tidur bagi pendidikan karakter. Ryan \& Bohlin (1999:89-90) menyatakan, terdapat kaitan langsung-sebagai hubungan sebab akibat-antara sistem pendidikan suatu bangsa dengan maju atau mundurnya bangsa tersebut. Kekuatan pendidikan bukan saja dalam membentuk karakter individual, tetapi juga karakter bangsa secara keseluruhan.

Masalahnya, kebijakan pendidikan di Indonesia selama ini, lebih mementingkan aspek kecerdasan otak. Barubaru ini saja pentingnya pendidikan budi pekerti menjadi bahan pembicaraan yang luas. Ada yang mengatakan bahwa kurikulum pendidikan di Indonesia hanya cocok untuk diberikan pada $10-20 \%$ otak-otak terbaik. Artinya sebagian besar anak sekolah (80-90\%) tidak 
dapat mengikuti kurikulum pelajaran di sekolah. Akibatnya, sejak usia dini, sebagian besar anak-anak akan merasa "bodoh" karena kesulitan menyesuaikan dengan kurikulum yang ada. Ditambah lagi dengan adanya sistem ranking yang telah "memvonis" anakanak yang tidak masuk "10 besar", sebagai anak yang kurang pandai. Sistem seperti ini tentunya berpengaruh negatif terhadap usaha membangun karakter, dimana sejak dini anak-anak justru sudah "dibunuh" rasa percaya dirinya

Rasa tidak mampu yang berkepanjangan akan membentuk pribadi yang tidak percaya diri dan menimbulkan stress berkepanjangan. Pada usia remaja keadaan ini biasanya akan mendorong untuk berperilaku negatif. Maka, tidak heran kalau kemudian muncul perilaku remaja, dan bahkan orang dewasa yang senang tawuran, terlibat kriminalitas, putus sekolah, koruptif, manipulatif, dan tidak tahu malu. Bahkan perbuatan yang sebelumnya dianggap memalukan menjadi biasa terjadi (Williams, Russell T. dan Ratna Megawangi, 2010).

Sebagian besar, bila tidak dapat dikatakan seluruhnya, kompetensi dasar yang disusun dalam standart isi kurikulum sekolah tidak menuntut secara eksplisit pengembangan karakter peserta didik. Tidak semua sekolah, bahkan mungkin tidak ada sekolah, yang merumuskan secara eksplisit tentang pencapaian pembangunan karakter peserta didik dalam dokumen kurikulumnya. Capaian karakter mungkin muncul dalam visi misi sekolah, namun dalam terjemahan pencapaian kurikulernya, jarang secara eksplisit dituangkan, baik dalam silabus, maupun rencana pelaksanaan pembelajaran. Oleh karena itu, menjadi 
tantangan bagi Kemendiknas dan seluruh jajarannya, untuk mendorong sekolah mengeksplisitkan target capaian pembelajaran dari sisi pengembangan karakter peserta didik. Dorongan tersebut dapat dimulai dari sosialisasi dan pelatihan terbatas dalam hal pengembangan perangkat pembelajaran berbasis pengembanagn karakter, yang dilanjutkan dengan perluasan melalui proses pengimbasan.

\section{Tantangan Personalia Pendidikan}

Pendidikan karakter di sekolah tidak dapat berjalan tanpa pemahaman yang cukup dan kosnsisten oleh seluruh personalia pendidikan. Di sekolah, kepala sekolah, guru, dan Karyawan, harus memiliki persamaan persepsi tentang pendidikan karakter bagi peserta didik. Setiap personalia pendidikan mempunyai perannya masing-masing. Kepala sekolah sebagai manajer, harus mempunyai komitmen yang kuat tentang pendidikan karakter. Kepala sekolah harus mampu membudayakan karakter-karakter unggul di sekolahnya. Pembudayaan karakter bukan saja berupa kebijakan dan atau aturan dengan segala sanksinya, namun juga harus melalui keteladanan perilaku sehari-hari. Keteladanan dalam hal kedisiplinan, tanggungjawab, perilaku bersih dan sehat, serta adil, merupakan sebagian dari pendidikan karakter yang selama ini masih sulit dilakukan. Budaya ewuh pekewuh, kadang menjadi hambatan kultural dalam menciptakan budaya berkarakter tersebut. Oleh karena itu, kepala sekolah sebagai pemimpin puncak di sekolah, memegang peran kunci mewujudkan karakter luhur tersebut. 
Selain kepala sekolah, guru merupakan personalia penting dalam pendidikan karakter di sekolah. Sebagian besar interaksi yang terjadi di sekolah, adalah interaksi peserta didik dengan guru. Baik melalui proses pembelajaran akademik kurikuler, kokurikuler, maupun ekstra-kurikuler. Pemahaman guru tentang pentingnya pendidikan karakter sangat menentukan keberhasilan implementasi pendidikan karakter di sekolah. Selama ini tidak banyak guru yang secara eksplisit telah mendisain kegiatan pembelajarannya untuk mengembangkan pendidikan karakter. Sebagian besar guru masih mendisain pembelajaran itu dalam rangka pencapain aspek kognitif peserta didik. Hal ini dapat terjadi, karena pemahaman guru tentang pendidikan karakter yang terbatas, atau karena penterjemahan tuntutan kurikuler yang tidak mencantumkan capain pembentukan karakter secara eksplisit. Uji yang dilakukan terhadap peserta didik selama ini, terbatas pada uji kompetensi secara kognitif dan psikomotorik. Oleh karena itu, diperlukan upaya perbaikan pemahaman guru tentang pentingnya pendidikan karakter bagi peserta didik pada setiap pembelajaran yang diberikannya. Hal ini dapat dilakukan melalui pelatihan dan lokakarya yang dapat melibatkan perguruan tinggi sebagai partner.

Kesulitan lain yang mungkin dihadapi guru adalah dalam hal penilaian. Pendidikan karakter merupakan suatu proses yang dimulai dari pemahaman, pembiasaan hingga ke pembudayaan, sehingga menjadi perilaku hidup sehari-hari. Hasil pendidikan karakter tidak dapat secara instan. Karakter yang terbentuk saat ini, mungkin merupakan hasil pendidikan karakter pada 
masamasa sebelumnya. Bila penilaian karakter yang ditanamkan pada peserta didik saat ini, diuji saat ini juga, mungkin belum menggambarkan hasil pendidikan karakter yang sebenarnya. Hasil pendidikan karakter saat ini, mungkin baru akan menjadi perilaku sehari-hari pada tahun-tahun berikutnya. Uji yang dilakukan diakhir pembelajaran, mungkin baru menggambarkan aspek pengetahuan karakter saja.

Hambatan yang dihadapi guru bisa bertambah, bila kemudian guru diminta mengevaluasi hasil pembelajarannya dengan target pendidikan karakter yang telah ditetapkan. Tidak semua guru dapat menyusun perangkat observasi yang menggambarkan karakter peserta didik secara tepat. Perumusan indikator dan deskriptor tentang perilaku disiplin misalnya, dapat sangat bervariasi diantara guru-guru dengan pengalaman hidup yang berbeda. Padahal, satu aspek karakter yang bersifat universal, seharusnya memiliki indikator dan deskriptor yang setara atau bahkan mungkin sama. Apakah semua guru dengan variabilitas tingkat pendidikan, pengalaman hidup, lingkungan sosial dan budaya, memiliki kemampuan yang sama dalam menyusun alat evaluasi karakter peserta didik? Hal ini merupakan tantangan bagi semua pihak yang peduli dengan pendidikan karakter dan masa depan generasi penerus bangsa. Perguruan tinggi perlu memainkan perannya, terutama dalam hal peningkatan kualitas guru dalam menyusun alat evaluasi pendidikan karakter di sekolah.

3. Tantangan Lingkungan dan Teknologi Informasi 
Perubahan lingkungan sosial yang mengglobal, tidak bisa dihindari oleh seluruh masyarakat dunia. Peserta didik yang dahulu hanya merupakan bagian dari masyaraka, suku, atau budaya tertentu; saat ini telah menjadi bagian dari masyarakat dunia. Kasus dan perilaku masyarakat yang sebelumnya hanya menjadi pengalaman hidup masyarakat terbatas, saat ini tidak bisa ditutup lagi. Peserta didik dapat manjadi bagaian masyarakat mana saja dengan segala keberagamannya. Perubahan kawasan pergaulan dari lokal menjadi global, telah mengubah tata nilai dan norma masyarakat. Perilaku yang sebelumnya tabu dan memalukan, saat ini dapat menjadi peristiwa yang biasa dan menjadi bahan pembicaraan. Perubahan tata nilai, bahkan hingga ke tata nilai agama, telah mengubah pengalaman hidup peserta didik, sehingga hasil pendidikan pasti akan dipengaruhi oleh perubahan-perubahan tersebut. Guru dan sekolah tidak bisa lagi membatasi pergaulan peserta didiknya pada satu sisi kehidupan yang diperbolehkan. Guru dan sekolah menghadapi tantangan pola pergaulan global peserta didik yang hampir tidak bisa dikendalikan dan dikenali.

Sistem informasi berteknologi tinggi yang memungkinkan anak menggunakan sebagian waktunya untuk mengakses informasi sendiri, memberi peluang sangat besar bagi anak memperoleh informasi tanpa seleksi. Media televisi, menurut Davies (2010) telah menyebabkan kepribadian anak menjadi individualistis, agresif, permisif, mengenal kata-kata jorok, pengetahuan seks lebih awal, penyalahgunaan obat, merokok, dan lebih suka menyelesaikan persoalan dengan 
kekerasan, perilaku tidak aman dan tidak sehat, serta kecenderungan obesitas karena junkfood.

Lickona (1992) terdapat sepuluh tanda perilaku manusia yang menunjukkan arah kehancuran suatu bangsa, yaitu (1)meningkatnya kekerasan di kalangan remaja; (2) ketidak jujuran yang membudaya; (3) tingginya rasa tidak hormat terhadap orang tua, guru dan figur pemimpin; (4) pengaruh teman sebaya terhadap perilaku kekerasan; (5) meningkatnya kecurigaan dan kebencian; (6) penggunaan bahasa yang memburuk; (7) penurunan etos kerja; (8) menurunnya tanggung jawab individu dan warga negara; (9) meningginya perilaku merusak diri; dan (10) semakin kaburnya pedoman moral (Ary Ginanjar Agustian dalam Zuchdi, 2009: 38). Ary Ginanjar Agustian (2009:39-40) menyatakan bahwa bangsa Indonesia saat ini mengalami tujuh krisis, yaitu krisis kejujuran, tanggung jawab, tidak berepikir jauh ke depan, disiplin, kebersamaan, keadilan dan kepedulian

Media informasi juga menjadi contoh bagi anak-anak. Sayangnya, contoh buruk cenderung lebih mudah mereka ikuti dibanding teladan yang baik. Kurangnya kesempatan orang tua mendampingi anak dan terbatasnya pengetahuan orang tua terhadap pendidikan, semakin menjerumuskan anak-anak ke jurang degradasi kepribadian. Sangat sulit mendidik anak untuk jujur ketika banyak sekali penipuan, korupsi, manipulasi, dalam pengalaman hidupnya. Sangat sulit mendidik anak untuk bekerja keras, ketika pengalaman hidupnya menunjukkan tanpa bekerja keraspun dapat hidup layak bahkan bermewah-mewah. Sangat 
sulit mendidik anak supaya berbuat adill, ketika berita di mass media menayangkan begitu runyamnya sistem penegakan hukum di negeri ini.

\section{F. Solusi}

Karakter seseorang akan terbentuk bila aktivitas dilakukan berulang-ulang secara rutin hingga menjadi suatu kebiasaan, yang akhirnya tidak hanya menjadi suatu kebiasaan saja tetapi sudah menjadi suatu karakter. Maka dari itu, pendidikan karakter harus dilakukan sedini mungkin agar anak mampu menanamkan karakter yang baik sehingga mereka bisa membawanya hingga usia dewasa. Pendidikan karakter di sekolah dapat diterapkan pada semua mata pelajaran.Setiap mata pelajaran yang berkaitan denga norma-norma perlu dikembangkan dan dikaitkan dengan kehidupan sehari-hari. Di era digital ini peran keluarga, guru dan masyarakat sekitar sangatlah penting dalam meningkatkan karakter calon penerus bangsa.Keluarga sebagai tempat utama dan pertama peserta didik menjalani kehidupan dan pendidikannya hendaklah mengawasi dan membimbing dengan penuh kasih sayang, tegas, dan cermat.Peran guru di sekolah bukan hanya mengajar tetapi juga mendidik. Peran guru sebagai rolemodel dalam pandangan anak sehingga guru akan menjadi patokan bagi sikap anak didik. Guru tidak hanya mengajarkan 
konsep karakter yang baik, tetapi bagaimana mengarahkan peserta didik untuk dapat mengimplementasikan pada kehidupam sehari-hari. Masyarakat sekitar juga berperan dalam mengawasi dan memotivasi perkembangan karakter peserta didik. 


\section{BAB V}

\section{EVALUASI PENDIDIKAN KARAKTER}

Evaluasi hasil belajar untuk domain kognitif umumnya dilakukan melalui tes berbagai bentuk, seperti tes objektif, tes uraian, tes kinerja, portofolio, observasi, atau bentuk lainnya. Pendidikan karakter lebih banyak menekankan pada hasil belajar untuk domain afektif dan psikomotor. Oleh karena itu, evaluasi pendidikan karakter dilakukan melalui teknik evaluasi yang sesuai untuk mengukur domain afektif dan psikomotor, seperti angket, inventori, portofolio, dan observasi atau pengamatan langsung.

Angket merupakan instrumen evaluasi berupa sejumlah pertanyaan tertulis yang diberikan kepada responden (Candiasa, 2010). Terdapat dua jenis angket, yakni angket terstruktur dan angket tidak terstruktur atau angket terbuka. Angket terstruktur adalah angket yang di dalamnya memuat pertanyaan yang disertai dengan pilihan jawaban. Angket tidak terstruktur atau angket terbuka tidak menyertakan pilihan jawaban yang diharapkan. Dengan kata lain, Responden dapat memberi respon secara bebas menurut pikirannya masing-masing.

Inventorri adalah instrument evaluasi berupa sejumlah pernyataan yang disertai rentang sekor untuk dipilih. Umumnya rentangan sekor dalam inventori bergerak dari satu kutub ke kutub yang lain. Misalnya sebuah inventori yang di dalamnya 
memuat peryataan tentang tata cara berpakaian. Rentangan sekor yang disedaiakan misalnya 1 sampai 10 , yang mana 1 berada pada kutub jelek dan 10 berada pada kutub 10. Penilai akan memberikan sekor sesuai hasil pengamatan yang dilakukan.

Asesmen portofolio mendasarkan penilaian pada kumpulan karya-karya yang dikerjakan siswa. Wyatt III dan Loper (1999) mendefinisikan portofolio sebagai suatu koleksi personal yang berisi bukti-bukti karya (artifak) serta refleksi siswa tentang pencapaian, perkembangan, kekuatan, dan karya terbaik sebagai hasil belajarnya. Portofolio juga diartikan sebagai kumpulan karya siswa dalam kurun waktu tertentu (Depdiknas, 2002). Pembatasan waktu dilakukan dengan ketat menggunakan alat ukur waktu yang tersedia pada sistem komputer.

Observasi adalah teknik evaluasi dengan cara mengamati langsung hasil belajar yang ingin dievaluasi. Instrumen observasi atau pengamatan langsung berupa lembar observasi yang memuat indikator-indikator yang menjadi pedoman dievaluasi dan telah dilengkapi dengan kriteria-kriteria untuk masing-masing indikator. Penilai dapat menuliskan informasi atau memberi tanda pada kriteria yang sudah diberikan. Selain observasi, interview juga efektif digunakan untuk evaluasi sikap (Muller, 1985).

\section{A. Tim Penilai}

Tujuan, perencanaan, dan pelaksanaan pendidikan karakter harus dibuat jelas sehingga mudah dievaluasi. Cara mengevaluasi pendidikan karakter juga harus dipertimbangkan 
dengan baik, mengingat diperlukan data yang akurat sebagai ukuran keberhasilan mencapai tujuan pendidikan karakter sebagai bahan laporan kepada masyarakat.

Sekolah merupakan tempat untuk validasi nilai, tempat kerja sama antara staf sekolah dengan anak dan dengan orang tua anak, tempat untuk mengetahui apakah pendidikan karakter berjalan dengan sukses atau tidak. Usaha untuk mempertahankan pendidikan karakter ada pada sekolah. Oleh karena itu, evaluasi pendidikan karakter sebaiknya dilakukan oleh tim evaluasi pendidikan karakter. Tim tersebut beranggotakan guru, pegawai administrasi, staf sekolah yang lain, orang tua, wakil masyarakat, siswa, dan ahli evaluasi dari suatu perguruan tinggi. Tugas tim evaluasi adalah menentukan apa yang harus dievaluasi, menentukan kapan, dimana, dan oleh siapa evaluasi dilaksanakan, dan membuat jadwal pelaksanaan evaluasi.

Dalam melaksanakan tugasnya, tim evaluasi harus mengikuti beberapa petunjuk pentinga, antara lain: 1) evaluasi harus mencakup indikator hasil belajar yang diinginkan dari implementasi program pendidikan karakter, sehingga masalahmasalah yang muncul dapat dikoreksi segera; 2) staf sekolah harus mereview hasil penilaian pendidikan karakter; 3) penilaian dilakukan dengan berbagai teknik, termasuk jurnal, anekdot, laporan-individu, survey, tes, angket, wawancara, dan sebagainya; 4) pembuatan disain dan langkah-langkah implementasi evaluasi pendidikan karakter harus melibatkan siswa, orang tua, dan staf sekolah; dan 5) sebaiknya diadakan 
kerjasama penilaian dengan perguruan tinggi atau lembaga terkait lainnya.

Kegiatan lain yang tidak kalah pentingnya adalah menyiapkan anggota tim agar mampu mengerjakan tugasnya masingmasing. Bila proses evaluasi sudah dilaksanakan, maka kegiatan pokok berikutnya adalah mengambil keputusan tentang nilai yang diperoleh siswa, dan kemudian memutuskan cara untuk menyebarkan hasil tersebut kepada peserta. Berdasarkan jadwal, tim kemudian menentukan langkah-langkah yang harus diambil berikutnya.

\section{B. Kriteria Penilaian}

Kriteria berfungsi sebagai pedoman dalam mengevaluasi pendidikan karakter. Kriteria adalah standar yang diyakini memiliki kepastian, sehingga sesuatu bisa diputuskan berdasarkan kriteria ini. Ada sebelas kriteria yang dipilih sebagai standar yang akan memandu usaha pendidikan karakter, yaitu kepedulian, kerjasama, komitmen, keberanian, perubahan, hubungan, koherensi, konsensus, komunikasi, budaya, dan kekritisan.

Kepedulian, yang meliputi prinsipprinsip seperti empati, antusiasme, dan perilaku pro-sosial adalah konsep yang menembus organisasi dari pemimpin sampai ke partisipan. Kerjasama mengarahkan bagaimana individu bersama-sama memecahkan masalah. Kerjasama adalah hubungan saling menguntungkan antara dua pihak atau lebih untuk mencapai 
tujuan melalui berbagi tanggung jawab, otoritas, dan akuntabilitas.

Komitmen ditujukan kepada individu untuk bekerjasama. Identitas seseorang adalah apa yang telah dia komitmenkan. Komitmen individu adalah mempersiapkan energi, fisik, atau psikologis bagi seseorang untuk melakukan sesuatu. Hubungan dalam pendidikan karakter komunikasi antarindividu, baik di sekolah maupun di masyarakat. Pemisahan, sekat, dan perpecahan yang disebabkan oleh ras, etnis, gender, usia, prestasi, materi pelajaran, bakat, kecakapan, politik, atau penghasilan adalah hal yang tidak diharapkan dan tidak perlu terjadi.

Fungsi terpenting bagi pendidikan karakter di masyarakat dan di sekolah adalah mencapai konsensus dalam nilai demokratis. Orang-orang di dalam dan di luar program perlu mengetahui apa yang terjadi dan mengapa. Perencanaan dan pelaksanaan program pendidikan karakter harus dilakukan secara terbuka, mengingat misi, harapan, gaya, dan metode merupakan hal yang sangat penting dipahami oleh semua staf sekolah dan masyarakat.

Budaya lingkungan sekolah, etos, atau kurikulum tersembunyi yang berdasarkan kriteria kepedulian dan konsensus merupakan inti dari program pendidikan karakter. Akhirnya pendidik perlu bersikap kritis agar bisa melakukan penilaian berdasarkan standar atau kriteria yang ada. Sikap kritis ditujukan terhadap apa yang dikatakan, dilakukan, dan bagaimana membuat model nilai-nilai yang diajarkan. 


\section{Evaluasi Pendidikan Karakter}

Evaluasi adalah suatu cara lembaga mewujudkan kinerja dan mutu yang efektif dan efisien dan lebih jauh mendukung terwujudnya visi/misi lembaga atau organisasi. Penilaian dan pengendalian merupakan fungsi ketiga dalam garis besar fungsi manajerial implementasi pendidikan karakter $^{88}$. Fungsi ini bertujuan menjamin kinerja yang dicapai agar sesuai dengan rencana dan tujuan yang telah ditetapkan ${ }^{89}$. Secara khusus, tujuan penilaian dilakukan untuk mengukur seberapa jauh nilai-nilai yang dirumuskan sebagai standar minimal yang telah dikembangkan dan ditanamkan di sekolah, serta dihayati diamalkan, diterapkan dan dipertahankan oleh peserta didik dalam kehidupan sehari-hari.

Pengawasan merupakan kunci keberhasilan dalam keseluruhan manajemen pendidikan, perlu dilihat secara komprehensif, terpadu, dan tidak terbatas pada hal-hal tertentu. Pengawasan atau pengendalian dapat diartikan sebagai upaya untuk mengamati secara sistematis dan berkesinambungan. Penilaian keberhasilan tersebut dilakukan melalui langkahlangkah, sebagai berikut:

1. Mengembangkan indikator dari nilai-nilai yang dikembangkan 
dan disepakati;

2. Menyusun berbagai instrumen penilaian;

3. Melakukan pencatatan terhadap pencapaian indikator;

4. Melakukan analisis dan evaluasi;

5. Melakukan tindak lanjut

Penilaian atau evaluasi dalam pendidikan karakter harus dilakukan secara terus menerus dan berkesinambungan, untuk mengetahui dan memantau perubahan serta kemjuan peserta didik, mapun untuk memberu skor, angka atau nilai yang bisa dikonversi dalam penilaian hasil belajar. Lebih rinci, sistem penilaian pendidikan karakter mencakup penilaian program, penilaian proses, dan penilaian hasil pendidikan karakter $^{91}$.

\section{a. Penilaian program pendidikan karakter}

Penilaian program pendidikan karakter harus diarahkan dan diprioritaskan pada program pembelajaran berkarakter, dan layanan sebagai kerangka kerja untuk pengelolaan kelas.

Aspek yang dinilai dari program pendidikan karakter sebagai berikut.

1. Penyusun perencanaan program

2. Masalah dan isu yang dijadikan obyek 
3. Pembagian tugas antara warga sekolah dan masyarakat dalam melaksanakan pendidikan karakter

4. Cara memadukan program pendidikan karakter dengan program sekolah yang lain dan dengan program masyarakat.

\section{b. Penilaian proses pendidikan karakter}

Penilaian proses dimaksudkan untuk meilai kualitas proses pendidikan karakter dan pembentukan kompetensi peserta didik, termasuk cara merealisasikan tujuan belajar. Salah satu bentuk penilaian proses pendidikan karakter dapat dilakukan di dalam kelas, terutama yang berkaitan dengan guru dan kurikulum.

Dalam penilaian proses pendidikan karakter, pengolah data, pembuat keputusan, dan pengguna keputusan yang pertama adalah peserta didik yang harus aktif dalam menganalisis dan mempertimbnagkan kegiatan belajarnya. Di samping itu, orang tua dan anggota masyarakat sebaiknya dilibatkan dalam pengolahan data, pembuat keputusan, dan penggunaan keputusan hasil penilaian proses pendidikan karakter. Hal ini diperlukan terutama untuk menciptakan proses pendidikan karakter yang berkesinambungan, sehingga akan terjadi perbaikan dan peningkatan karakter secara bertahap, menuju 
terbentuknya pribadi yang berkarakter utuh.

\section{c. Penilaian hasil pendidikan karakter}

Penilaian hasil pendidikan karakter merupakan suatu kegiatan mengukur perubahan perilaku (karakter) yang telah terbentuk. Pada umumnya haisl pendidikan karakter akan memberikan pengaruh dalam dua bentuk yakni perspektif peserta didik terhadap kekuatan dan kelemahannya atas karakter yang diinginkan.

Penilaian pendidikan karakter lebih banyak menenkankan pada aspek sikap, yang dilakukan dengan daftar isian karakte sendiri, daftar issi karakter yang disesuaikan dengan standar komptensi dan komptensi dasar, serta skala diferensial berkarakter. Skala deferinsial berkarakter merupakan pengembangan dari Skala Diferensial Semantik yang lebih ditenaknkan pada penilaian karakter tertentu dari setiap peserta didik.

\section{d. Teknik Penilaian (Evaluasi) Pendidikan Karakter}

Untuk melakukan evaluasi terhadap program yang telah dibuat, terlebih dahulu hendaknya menyusun rencana evaluasi sekaligus menyusun instrument pengumpulan 
data. Instrument pengumpul data tersebut bisa berupa tes, angket, pedoman wawancara, observasi dan lain sebagainya. Sebagai cara yang paling sederhana adalah menagadakan pendekatan terhadap peristiwa yang dialami sehari-hari di kelas.

Untuk mengevaluasi progam, seorang guru tidak perlu dibebani secara sistematis sebagaimana layaknya seorang peneliti. Akan tetapi guru cukup membuat acuan singkat dan sederhana yang disusun dalm bentuk pertanyaan. Dari jawaban atas pertanyaan-pertanyaan tersebut guru akan memperoleh umpan balik terhadap apa yang dilakukan. Pertanyaan-pertanyaan yang diajukan berkaitan dengan objek atau sasaran evaluasi yang meliputi input, proses dan output.

Ada banyak instrument yang tersedia dan dapat digunakan oleh evaluator (guru) dalam menjalankan evaluasi karakter terhadap peserta didiknya, diantaranya adalah sebagai berikut:

1. Evaluasi diri oleh anak itu sendiri,

2. Penilaian teman,

3. Catatan anekdot guru,

4. Catatan anekdot orang tua,

5. Catatan perkembangan aktivitas anak (psikolog),

6. Lembar observasi guru,

7. Lembar kerja siswa (LKS),

8. Penilaian portofolio.

Sedangkan menurut Burhanudin Tola juga dapat dilakukan dengan beberapa cara atau teknik, selain dari 
teknik yang di atas, yaitu: Observasi perilaku, Pertanyaan Langsung, Laporan Pribadi, Penggunaan Skala Sikap.

Kunandar menyebutkan bahwa ada tiga teknik evaluasi atau penilaian sikap dan karakter, yakni dengan menggunakan: Observasi Perilaku, Pertanyaan Langsung, Laporan Pribadi.

Berikutnya menurut Wayan Nurkancana, sikap atau karakter dapat dinilai dengan berbagai teknik diantaranya adalah: Kuesioner, Interview, Observasi.

Selanjutnya Thorndike mengatakan bahwa sikap dan karakter pada diri siswa dapat dinilai dengan metode:

1. Self descriptive,

2. Auto biografi,

3. Interviu langsung dan tak langsung,

4. Angket langsung dan tak langsung,

5. Cumulative record,

6. Case study,

7. Observasi,

8. Inventori,

9. Proyektif

Lebih jauh, Isdisusilo mengatakan bahwa perlu diperhatikan penilaian tidak dapat diberikan hanya pada sekali pengamatan saja. Penilaian pun dilakukan di kelas dan di lingkungan sekolah. Untuk memudahkan guru dalam mendokumentasi hasil pengamatan, maka dapat digunakan sistem pencatatan anecdotal record. Hal ini benar, karena sifat seseorang 
atau sifat anak bisa berubah setiap saat tanpa direncanakan sebelumnya.

Ada beberapa kemampuan yang harus dimiliki oleh seorang evaluator pendidikan dalam melakukan evaluasi pendidikan karakter, diantaranya:

1. Mempunyai kecermatan dalam melihat celah-celah dan detail dari program serta bagian program yang akan dievaluasi.

2. Mengedepankan ketelitian, kesabaran dan ketekunan dalam melaksanakan tugas evaluasi

3. Bersikap Hati-hati dalam bertugas dan bertanggung jawab jika ada kesalahan.

4. Mempunyai kemampuan melaksanakan evaluasi yang didukung oleh teori dan keterampilan praktik.

5. Bersikap Objektif terhadap pengumpulan data dan tidak dipengaruhi oleh sesuatu apapun.

6. Menguasai nilai, baik nilai universal maupun lokal sebagai acuan basis evaluasi/penilaian. 


\section{BAB VI}

\section{MEMBANGUN KARAKTER POSITIF DALAM PEMBELAJARAN}

\section{A. Pribadi Positif}

\section{Pengertian Kepribadian}

Para ahli tampaknya masih sangat beragam dalam memberikan rumusan tentang kepribadian. Dalam suatu penelitian kepustakaan yang dilakukan oleh Gordon W. Allport (Calvin S. Hall dan Gardner Lindzey, 2005) menemukan hampir 50 definisi tentang kepribadian yang berbeda-beda. Berangkat dari studi yang dilakukannya, akhirnya dia menemukan satu rumusan tentang kepribadian yang dianggap lebih lengkap. Menurut pendapat dia bahwa kepribadian adalah organisasi dinamis dalam diri individu sebagai sistem psiko-fisik yang menentukan caranya yang unik dalam menyesuaikan diri terhadap lingkungannya. Kata kunci dari pengertian kepribadian adalah penyesuaian diri. Scheneider (1964) mengartikan penyesuaian diri sebagai "suatu proses respons individu baik yang bersifat behavioral maupun mental dalam upaya mengatasi kebutuhan-kebutuhan dari dalam diri, ketegangan emosional, 
frustrasi dan konflik, serta memelihara keseimbangan antara pemenuhan kebutuhan tersebut dengan tuntutan (norma) lingkungan.

Sedangkan disebut unik, karena kualitas perilaku itu khas sehingga dapat dibedakan antara individu satu dengan individu lainnya. Keunikannya itu didukung oleh keadaan struktur psikofisiknya, misalnya konstitusi dan kondisi fisik, tampang, hormon, segi kognitif dan afektifnya yang saling berhubungan dan berpengaruh, sehingga menentukan kualitas tindakan atau perilaku individu yang bersangkutan dalam berinteraksi dengan lingkungannya.

Terdapat beberapa teori kepribadian yang sudah banyak dikenal, diantaranya : teori Psikoanalisa dari Sigmund Freud, teori Analitik dari Carl Gustav Jung, teori Sosial Psikologis dari Adler, Fromm, Horney dan Sullivan, teori Personologi dari Murray, teori Medan dari Kurt Lewin, teori Psikologi Individual dari Allport, teori Stimulus-Respons dari Throndike, Hull, Watson, teori The Self dari Carl Rogers dan sebagainya. Sementara itu, Abin Syamsuddin (2003) mengemukakan tentang aspek-aspek kepribadian, yang di dalamnya mencakup : 
a. Karakter yaitu konsekuen tidaknya dalam mematuhi etika perilaku, konsiten tidaknya dalam memegang pendirian atau pendapat.

b. Temperamen yaitu disposisi reaktif seorang, atau cepat lambatnya mereaksi terhadap rangsangan-rangsangan yang datang dari lingkungan.

c. Sikap; sambutan terhadap objek yang bersifat positif, negatif atau ambivalen.

d. Stabilitas emosi yaitu kadar kestabilan reaksi emosional terhadap rangsangan dari lingkungan. Seperti mudah tidaknya tersinggung, marah, sedih, atau putus asa

e. Responsibilitas (tanggung jawab) adalah kesiapan untuk menerima risiko dari tindakan atau perbuatan yang dilakukan.

Seperti mau menerima risiko secara wajar, cuci tangan, atau melarikan diri dari risiko yang dihadapi.

f. Sosiabilitas yaitu disposisi pribadi yang berkaitan dengan hubungan interpersonal. Seperti : sifat pribadi yang terbuka atau tertutup dan kemampuan berkomunikasi dengan orang lain.

\section{Ciri-ciri Pribadi Positif}


Setiap individu memiliki ciri-ciri kepribadian tersendiri, mulai dari yang menunjukkan kepribadian yang positif dan yang tidak positif. Dalam hal ini, Elizabeth (Syamsu Yusuf, 2003) mengemukakan ciri-ciri kepribadian yang positif, sebagai berikut:

a. Mampu menilai diri sendiri secara realisitik; mampu menilai diri apa adanya tentang kelebihan dan kekurangannya, secara fisik, pengetahuan, keterampilan dan sebagainya.

b. Mampu menilai situasi secara realistik; dapat menghadapi situasi atau kondisi kehidupan yang dialaminya secara realistik dan mau menerima secara wajar, tidak mengharapkan kondisi kehidupan itu sebagai sesuatu yang sempurna.

c. Mampu menilai prestasi yang diperoleh secara realistik; dapat menilai keberhasilan yang diperolehnya dan meraksinya secara rasional, tidak menjadi sombong, angkuh atau mengalami superiority complex, apabila memperoleh prestasi yang tinggi atau kesuksesan hidup. Jika mengalami kegagalan, dia tidak mereaksinya dengan frustrasi, tetapi dengan sikap optimistik.

d. Menerima tanggung jawab; dia mempunyai keyakinan terhadap kemampuannya untuk mengatasi masalah-masalah kehidupan yang dihadapinya. 
e. Kemandirian; memiliki sifat mandiri dalam cara berfikir, dan bertindak, mampu mengambil keputusan, mengarahkan dan mengembangkan diri serta menyesuaikan diri dengan norma yang berlaku di lingkungannya.

f. Dapat mengontrol emosi; merasa nyaman dengan emosinya, dapat menghadapi situasi frustrasi, depresi, atau stress secara positif atau konstruktif, tidak destruktif.

g. Berorientasi tujuan; dapat merumuskan tujuan-tujuan dalam setiap aktivitas dan kehidupannya berdasarkan pertimbangan secara matang (rasional), tidak atas dasar paksaan dari luar, dan berupaya mencapai tujuan dengan cara mengembangkan kepribadian (wawasan), pengetahuan dan keterampilan.

h. Berorientasi keluar (ekstrovert); bersifat respek, empati terhadap orang lain, memiliki kepedulian terhadap situasi atau masalahmasalah lingkungannya dan bersifat fleksibel dalam berfikir, menghargai dan menilai orang lain seperti dirinya, merasa nyaman dan terbuka terhadap orang lain, tidak membiarkan dirinya dimanfaatkan untuk menjadi korban orang lain dan mengorbankan orang lain, karena kekecewaan dirinya.

i. Penerimaan sosial; mau berpartsipasi aktif dalam kegiatan sosial dan memiliki sikap bersahabat dalam berhubungan dengan orang lain. 
j. Memiliki filsafat hidup; mengarahkan hidupnya berdasarkan filsafat hidup yang berakar dari keyakinan agama yang dianutnya.

k. Berbahagia; situasi kehidupannya diwarnai kebahagiaan, yang didukung oleh faktor-faktor achievement (prestasi), acceptance (penerimaan), dan affection (kasih sayang).

\section{Nilai-nilai Karakter di Sekolah}

Sekolah merupakan tempat interaksi para siswa siswi dalam proses belajar mengajar, oleh karena itu sekolah menjadi lembaga pembentuk karakter siswa yang paling efektif. Guru maupun pengelola sekolah lainnya menjadi aktor utama sebagai model yang akan ditauladani peserta didik di sekolah.

Pendidikan karakter adalah suatu sistem penanaman nilainilai karakter kepada warga sekolah yang meliputi komponen pengetahuan, kesadaran atau kemauan, dan tindakan untuk melaksanakan nilai-nilai tersebut. Pendidikan karakter dapat dimaknai sebagai "the deliberate use of all dimensions of school life to foster optimal character development". Dalam pendidikan karakter di sekolah, semua komponen (pemangku pendidikan) harus dilibatkan, termasuk komponen-komponen pendidikan itu sendiri, yaitu isi kurikulum, proses pembelajaran dan penilaian, 
penanganan atau pengelolaan mata pelajaran, pengelolaan sekolah, pelaksanaan aktivitas atau kegiatan ko-kurikuler, pemberdayaan sarana prasarana, pembiayaan, dan ethos kerja seluruh warga sekolah/lingkungan. Di samping itu, pendidikan karakter dimaknai sebagai suatu perilaku warga sekolah yang dalam menyelenggarakan pendidikan harus berkarakter.

Dewasa ini banyak pihak menuntut peningkatan intensitas dan kualitas pelaksanaan pendidikan karakter pada lembaga pendidikan formal. Tuntutan tersebut didasarkan pada fenomena sosial yang berkembang, yakni meningkatnya kenakalan remaja dalam masyarakat, seperti perkelahian massal dan berbagai kasus dekadensi moral lainnya. Bahkan di kota-kota besar tertentu, gejala tersebut telah sampai pada taraf yang sangat meresahkan. Oleh karena itu, lembaga pendidikan formal sebagai wadah resmi pembinaan generasi muda diharapkan dapat meningkatkan peranannya dalam pembentukan kepribadian peserta didik melalui peningkatan intensitas dan kualitas pendidikan karakter.

Hasil kajian pusat kurikulum nasional menyimpulkan bahwa terdapat 18 nilai karakter bangsa yang penting untuk ditanamkan pada diri setiap peserta didik. Nilai karakter bangsa 
yang dimaksud adalah religius, jujur, toleransi, disiplin, kerja keras, kreatif, mandiri, demokratis, rasa ingin tahu, semangat kebangsaan, cinta tanah air, menghargai prestasi, bersahabat/komunikatif, cinta damai, gemar membaca, peduli lingkungan, peduli sosial, tanggung jawab.

Proses pendidikan karakter didasarkan pada totalitas psikologis yang mencakup seluruh potensi individu manusia (kognitif, afektif, psikomotorik) dan fungsi totalitas sosiokultural dalam konteks interaksi dalam keluarga, sekolah, dan masyarakat yang berlangsung sepanjang hayat. Konfigurasi karakter dalam kontek totalitas proses psikologis dan sosial-kultural dapat dikelompokkan dalam: (1) olah hati (spiritual \& emotional development); (2) olah pikir (intellectual development); (3) olah raga dan kinestetik (physical \& kinesthetic development); dan (4) olah rasa dan karsa (affective and creativity development). Proses itu secara holistik dan koheren memiliki saling keterkaitan dan saling melengkapi, serta secara konseptual merupakan gugus nilai luhur bangsa Indonesia.

\section{B. Integrasi Pendidikan Karakter dalam Kurikulum Sekolah}


Karakter adalah watak, tabiat, akhlak, atau kepribadian seserang yang terbentuk dari hasil internalisasi berbagai kebajikan (virtues) yang diyakini dan digunakan sebagai landasan untuk cara pandang, berpikir, bersikap, dan bertindak. Kebajikan terdiri atas sejumlah nilai, moral, dan norma, seperti: jujur, berani bertindak, dapat dipercaya, dan hormat kepada orang lain. Interaksi seseorang dengan orang lain menumbuhkan karakter masyarakat dan karakter bangsa. Oleh karena itu, pengembangan karakter bangsa hanya dapat dilakukan melalui pengembangan karakter individu seseorang. Akan tetapi, karena manusia hidup dalam lingkungan sosial dan budaya tertentu, maka pengembangan karakter individu seserang hanya dapat dilakukan dalam lingkungan sosial dan budaya yang bersangkutan. Artinya, pengembangan budaya dan karakter bangsa hanya dapat dilakukan dalam suatu proses pendidikan yang tidak melepaskan peserta didik dari lingkungan sosial, budaya masyarakat, dan budaya bangsa.

Lingkungan sosial dan budaya bangsa adalah Pancasila; jadi pendidikan budaya dan karakter bangsa haruslah berdasarkan nilai-nilai Pancasila. Dengan kata lain, mendidik budaya dan karakter bangsa adalah mengembangkan nilai-nilai Pancasila pada diri peserta didik melalui pendidikan hati, otak, dan fisik. 
Pendidikan adalah suatu usaha yang sadar dan sistematis dalam mengembangkan potensi peserta didik. Pendidikan adalah juga suatu usaha masyarakat dan bangsa dalam mempersiapkan generasi mudanya bagi keberlangsungan kehidupan masyarakat dan bangsa yang lebih baik di masa depan. Keberlangsungan itu ditandai oleh pewarisan budaya dan karakter yang telah dimiliki masyarakat dan bangsa. Oleh karena itu, pendidikan adalah proses pewarisan budaya dan karakter bangsa bagi generasi muda dan juga proses pengembangan budaya dan karakter bangsa untuk peningkatan kualitas kehidupan masyarakat dan bangsa di masa mendatang. Dalam proses pendidikan budaya dan karakter bangsa, secara aktif peserta didik mengembangkan potensi dirinya, melakukan proses internalisasi, dan penghayatan nilainilai menjadi kepribadian mereka dalam bergaul di masyarakat, mengembangkan kehidupan masyarakat yang lebih sejahtera, serta mengembangkan kehidupan bangsa yang bermartabat.

Berdasarkan pengertian budaya, karakter bangsa, dan pendidikan yang telah dikemukakan di atas maka pendidikan budaya dan karakter bangsa dimaknai sebagai pendidikan yang mengembangkan nilai-nilai budaya dan karakter bangsa pada diri peserta didik sehingga mereka memiliki nilai dan karakter sebagai karakter dirinya, menerapkan nilai-nilai tersebut dalam 
kehidupan dirinya, sebagai anggota masyarakat, dan warganegara yang religius, nasionalis, produktif dan kreatif. Atas dasar pemikiran itu, pengembangan pendidikan budaya dan karakter sangat strategis bagi keberlangsungan dan keunggulan bangsa di masa mendatang. Pengembangan itu harus dilakukan melalui perencanaan yang baik, pendekatan yang sesuai, dan metode belajar serta pembelajaran yang efektif. Sesuai dengan sifat suatu nilai, pendidikan budaya dan karakter bangsa adalah usaha bersama sekolah; oleh karenanya harus dilakukan secara bersama oleh semua guru dan pemimpin sekolah, melalui semua mata pelajaran, dan menjadi bagian yang tak terpisahkan dari budaya sekolah. Pendidikan adalah suatu proses enkulturasi, berfungsi mewariskan nilai-nilai dan prestasi masa lalu ke generasi mendatang.

Nilai-nilai dan prestasi itu merupakan kebanggaan bangsa dan menjadikan bangsa itu dikenal oleh bangsa-bangsa lain. Selain mewariskan, pendidikan juga memiliki fungsi untuk mengembangkan nilai-nilai budaya dan prestasi masa lalu itu menjadi nilai-nilai budaya bangsa yang sesuai dengan kehidupan masa kini dan masa yang akan datang, serta mengembangkan prestasi baru yang menjadi karakter baru bangsa. Oleh karena itu, 
pendidikan budaya dan karakter bangsa merupakan inti dari suatu proses pendidikan.

Dalam pendidikan karakter di sekolah, semua komponen (pemangku pendidikan) harus dilibatkan, termasuk komponenkomponen pendidikan itu sendiri, yaitu isi kurikulum, proses pembelajaran dan penilaian, penanganan atau pengelolaan mata pelajaran, pengelolaan sekolah, pelaksanaan aktivitas atau kegiatan ko-kurikuler, pemberdayaan sarana prasarana, pembiayaan, dan ethos kerja seluruh warga sekolah/lingkungan. Di samping itu, pendidikan karakter dimaknai sebagai suatu perilaku warga sekolah yang dalam menyelenggarakan pendidikan harus berkarakter.

Proses pengembangan nilai-nilai yang menjadi landasan dari karakter itu menghendaki suatu proses yang berkelanjutan, dilakukan melalui berbagai mata pelajaran yang ada dalam kurikulum. Dengan terobosan kurikulum yang demikian, nilai dan karakter yang dikembangkan pada diri peserta didik akan sangat kokoh dan memiliki dampak nyata dalam kehidupan diri, masyarakat, bangsa, dan bahkan umat manusia.Pendidikan budaya dan karakter bangsa dilakukan melalui pendidikan nilai- 
nilai atau kebajikan yang menjadi nilai dasar budaya dan karakter bangsa. Kebajikan yang menjadi atribut suatu karakter pada dasarnya adalah nilai. Oleh karena itu pendidikan budaya dan karakter bangsa pada dasarnya adalah pengembangan nilai-nilai yang berasal dari pandangan hidup atau idelgi bangsa Indonesia, agama, budaya, dan nilai-nilai yang terumuskan dalam tujuan pendidikan nasional.

Pengembangan nilai-nilai pendidikan budaya dan karakater bangsa diintegrasikan dalam setiap pokok bahasan dari setiap mata pelajaran. Nilai-nilai tersebut dicantumkan dalam silabus dan RPP. Menurut Zubaidi (2011), pengembangan nilainilai itu dalam silabus ditempuh melalui cara-cara: a.) mengkaji Standar Kompetensi (SK) dan Kompetensi Dasar (KD) pada Standar Isi (SI) untuk menentukan apakah nilai-nilai budaya dan karakter bangsa yang tercantum itu sudah tercakup di dalamnya; b.) menggunakan tabel 1 yang memperlihatkan keterkaitan antara SK dan KD dengan nilai dan Indikator untuk menentukan nilai yang akan dikembangkan; c.) mencantumkankan nilai-nilai budaya dan karakter bangsa dalam tabel 1 itu ke dalam silabus; d.) mencantumkan nilai-nilai yang sudah tertera dalam silabus ke dalam RPP; e.) mengembangkan proses pembelajaran peserta didik secara aktif yang memungkinkan peserta didik memiliki 
kesempatan melakukan internalisasi nilai dan menunjukkannya dalam perilaku yang sesuai; dan f.) memberikan bantuan kepada peserta didik, baik yang mengalami kesulitan untuk menginternalisasi nilai maupun untuk menunjukkannya dalam perilaku.

\section{Pengembangan Proses Pembelajaran}

Pembelajaran pendidikan budaya dan karakter bangsa menggunakan pendekatan proses belajar peserta didik secara aktif dan berpusat pada anak; dilakukan melalui berbagai kegiatan di kelas, sekolah, dan masyarakat.

a. Kelas, melalui proses belajar setiap mata pelajaran atau kegiatan yang dirancang sedemikian rupa. Setiap kegiatan belajar mengembangkan kemampuan dalam ranah kgnitif, afektif, dan psikmtr. Oleh karena itu, tidak selalu diperlukan kegiatan belajar khusus untuk mengembangkan nilai-nilai pada pendidikan budaya dan karakter bangsa. Meskipun demikian, untuk pengembangan nilai-nilai tertentu seperti kerja keras, jujur, Toleransi, disiplin, mandiri, semangat kebangsaan, cinta tanah air, dan gemar membaca dapat melalui kegiatan belajar yang biasa dilakukan guru. Untuk pegembangan beberapa nilai lain 
seperti peduli sosial, peduli lingkungan, rasa ingin tahu, dan kreatif memerlukan upaya pengkondisian sehingga peserta didik memiliki kesempatan untuk memunculkan perilaku yang menunjukkan nilai-nilai itu.

b. Sekolah, melalui berbagai kegiatan sekolah yang diikuti seluruh peserta didik, guru, kepala sekolah, dan tenaga administrasi di sekolah itu, direncanakan sejak awal tahun pelajaran, dimasukkan ke Kalender Akademik dan yang dilakukan sehari-hari sebagai bagian dari budaya sekolah. Contoh kegiatan yang dapat dimasukkan ke dalam program sekolah adalah lomba vocal grup antarkelas tentang lagu-lagu bertema cinta tanah air, pagelaran seni, lomba pidato bertema budaya dan karakter bangsa, pagelaran bertema budaya dan karakter bangsa, lomba olah raga antarkelas, lomba kesenian antarkelas, pameran hasil karya peserta didik bertema budaya dan karakter bangsa, pameran foto hasil karya peserta didik bertema budaya dan karakter bangsa, lomba membuat tulisan, lomba mengarang lagu, melakukan wawancara kepada tokoh yang berkaitan dengan budaya dan karakter bangsa, mengundang berbagai narasumber untuk berdiskusi, gelar wicara, atau berceramah yang berhubungan dengan budaya dan karakter bangsa. 
c. Luar sekolah, melalui kegiatan ekstrakurikuler dan kegiatan lain yang diikuti leh seluruh atau sebagian peserta didik, dirancang sekolah sejak awal tahun pelajaran, dan dimasukkan ke dalam Kalender Akademik. Misalnya, kunjungan ke tempattempat yang menumbuhkan rasa cinta terhadap tanah air, menumbuhkan semangat kebangsaan, melakukan pengabdian masyarakat untuk menumbuhkan kepedulian dan kesetiakawanan sosial (membantu mereka yang tertimpa musibah banjir, memperbaiki atau membersihkan tempat-tempat umum, membantu membersihkan atau mengatur barang di tempat ibadah tertentu).

\section{Penilaian Hasil Belajar}

Penilaian pencapaian pendidikan nilai budaya dan karakter didasarkan pada indikator. Sebagai contoh, indikator untuk nilai jujur di suatu semester dirumuskan dengan "mengatakan dengan sesungguhnya perasaan dirinya mengenai apa yang dilihat, diamati, dipelajari, atau dirasakan" maka guru mengamati (melalui berbagai cara) apakah yang dikatakan seorang peserta didik itu jujur mewakili perasaan dirinya. Mungkin saja peserta didik menyatakan perasaannya itu secara 
lisan tetapi dapat juga dilakukan secara tertulis atau bahkan dengan bahasa tubuh. Perasaan yang dinyatakan itu mungkin saja memiliki gradasi dari perasaan yang tidak berbeda dengan perasaan umum teman sekelasnya sampai bahkan kepada yang bertentangan dengan perasaan umum teman sekelasnya. Penilaian dilakukan secara terus menerus, setiap saat guru berada di kelas atau di sekolah. Model anecdotal record (catatan yang dibuat guru ketika melihat adanya perilaku yang berkenaan dengan nilai yang dikembangkan) selalu dapat digunakan guru.

Selain itu, guru dapat pula memberikan tugas yang berisikan suatu persoalan atau kejadian yang memberikan kesempatan kepada peserta didik untuk menunjukkan nilai yang dimilikinya. Sebagai contoh, peserta didik dimintakan menyatakan sikapnya terhadap upaya menolong pemalas, memberikan bantuan terhadap orang kikir, atau hal-hal lain yang bersifat bukan kontroversial sampai kepada hal yang dapat mengundang konflik pada dirinya. 


\section{BAB VII}

\section{CARING DALAM PEMBELAJARAN}

\section{A. Caring Guru dalam Pembelajaran}

Guru merupakan faktor yang dominan dan penting dalam pendidikan formal. Bahkan bagi peserta didik, guru sering dijadikan teladan. Mutu pendidikan yang baik sangat dipengaruhi kinerja guru dalam melaksanakan tugasnya sehingga kinerja guru menjadi tuntutan penting untuk mencapai keberhasilan pendidikan. Sebagai konsekuensinya, guru dituntut untuk mampu menguasai materi pelajaran, menguasai cara-cara menyesuaikan diri dan berkepribadian dalam menjalankan tugasnya untuk menjadi pribadi yang berkembang dan dinamis. ${ }^{1}$

Guru SD dituntut untuk mampu menyelenggarakan pembelajaran yang mendidik, berkomunikasi secara efektif, empatik, dan santun dengan peserta didik, serta mampu menampilkan diri sebagai pribadi yang jujur, berakhlak mulia, dan teladan bagi peserta didik dan masyarakat. Guru SD yang diinginkan oleh siswa adalah guru yang bisa menjalin hubungan 
baik dengan muridnya, sehingga akan mengerti bagaimana menghadapi murid-muridnya. Guru tersebut mengetahui metode apa yang tepat untuk mengajar. (Palmer, 1998).

Beberapa survey awal yang dilakukan peneliti ke beberapa SD serta wawancara dengan beberapa wali siswa, ditemukan fakta bahwa banyak guru tidak menyadari makna penting kompetensi sebagai guru SD, sehingga dalam proses belajar mengajar mereka tidak menunjukkan sikap yang mampu mendorong pembelajaran yang mendidik. Beberapa SD membuat slogan sekolah dengan $3 \mathrm{~S}$ (senyum, salam, sapa), tapi slogan tersebut hanya menjadi simbol atau slogan tanpa makna, karena hanya terpampang di tembok sekolah yang tidak dipahami dan diterapkan sehingga menjadi budaya sekolah.

Salah satu contoh dari aktivitas tersebut, pada pagi hari sebelum pembelajaran dimulai, SD yang diobservasi membiasakan salam dengan kegiatan guru bersalaman saat akan masuk kelas. Guru berbaris menyambut kehadiran siswa di gerbang sekolah yang berjejer antri berjabat tangan dengan guru sudah menjadi sebuah rutinitas. Akan tetapi pada saat menyambut dengan bersalaman, tidak jarang ditemukan guru menerima salam 
tangan siswa sambil ngobrol dengan guru di sebelahnya. Ada juga yang sambil menggenggam handphone dan sesekali mengangkat telpon masuk atau membalas Short Message Service (SMS). Ini menunjukkan, bahwa guru tidak memiliki pengetahuan dan pemahaman, bagaimana seharusnya melayani siswa dengan baik.

Dalam proses pembelajaran di beberapa sekolah juga ditemukan, siswa dituntut untuk berani bertanya maupun menjawab pertanyaan guru, namun apresiasi yang diterima tidak sesuai harapan siswa. Pada saat siswa menjawab pertanyaan kurang tepat, guru langsung mengalihkan ke siswa lain sambil berkata 'salah' tanpa ada penjelasan di sisi mana kesalahan siswa, bahkan ada yang lebih dari itu, bentakan juga menyertai sehingga di pembelajaran-pembelajaran berikutnya, siswa takut untuk bertanya ataupun menjawab pertanyaan guru karena malu dan takut jika dikatakan 'salah' lagi. Bahkan saat mengajar di kelas, guru duduk di depan sampai pelajaran berakhir. Mereka tidak mendekati siswa sama sekali ke tempat duduknya atau saat mereka mengerjakan tugas. Fakta lain juga menjelaskan, di luar kelas, jarak antara guru dan siswa cukup jauh, karena guru memahami bahwa tugasnya sebagai guru hanya pada saat di kelas. Guru merasa tidak perlu tahu apa yang dikeluhkan, 
diinginkan, dan dirasakan siswa. Lebih-lebih dengan masalah siswa di rumah.

\section{B. Urgensi Caring dalam Pembelajaran}

Akhir dekade ini ada sebuah dorongan untuk menggeser pendekatan-pendekatan konvensional dengan mengimplementasikan pendekatan-pendekatan yang berfokus pada pengembangan komunitas caring (Paul, 2005). Kebanyakan siswa memanggil guru favoritnya dengan menyebut namanya. Tetapi jika ditanya apa yang diingat dari guru tersebut, seringkali dijawab bahwa guru tersebut care pada setiap siswa. Ditemukan adanya hubungan antara guru dan siswa tentang kebutuhan dasar manusia untuk mengetahui bahwa orang lain sesungguhnya care terhadapnya. Para siswa mengetahui kapan saatnya mereka diakui, dipahami, dan dihargai kemampuan unik mereka dan keingintahuan mereka oleh guru (Lumpkin, 2007). Caring merupakan butir personal yang mendasar bagi guru. caring guru memainkan peranan yang vital bagi persepsi siswa dalam pembelajaran, sikap, kepuasan, dan persepsi kompetensi guru serta kepercayaan siswa terhadap guru (Teven, 2001). 
Pendekatan yang berfokus pada caring ini bermula pada penelitian persepsi siswa tentang 'guru yang baik'. Beberapa tahun kemudian hasil penelitian menunjukkan bahwa persepsi siswa tentang 'guru yang baik' adalah guru yang memiliki sikap prososial, perilaku yang bertanggung jawab, taat pada norma dan aturan kelas, serta mendorong pada aktivitas-aktivitas akademik (Wentzel, 1997).

Caring secara luas diyakini menjadi aspek penting dalam pembelajaran. Kohl, sebagai contoh, menegaskan bahwa seorang guru memiliki kewajiban untuk care pada setiap siswa. Sedangkan Rogers dan Webb menyatakan bahwa guru yang baik adalah guru yang care, dan pembelajaran yang baik adalah pembelajaran yang tidak dapat dipisahkan dari tindakan caring (Rogers, 1991). Noddings menulis, caring seharusnya ada dalam praktek pembelajaran (Noddings, 1984)

Pada saat caring diterapkan dalam pembelajaran, bentuk aktivitas yang dilakukan adalah mengutamakan dialog, menunjukkan sensitivitas pada kebutuhan dan keinginan siswa, dan memberikan materi dan aktivitas yang kaya dan penuh makna. ${ }^{2}$ Caring dapat menjadi dasar bagi guru untuk membuat 
keputusan (Noddings, 1992) Smith menyatakan bahwa caring sebagai science dalam pendidikan dan ide dalam pengajaran yang merupakan sebuah tindakan 'cinta' (dalam Murray Orr, 2002). Menurut Noddings caring dapat terjadi dalam hubungan dua orang, dan ini adalah sebuah aspek dari komunikasi. Komunikasi berakar pada bahasa, baik verbal maupun nonverbal. Jika terjadi komunikasi antara dua orang dengan dua bahasa yang berbeda, maka mereka akan memiliki dua cara memaknainya dengan cara yang berbeda. Miskomunikasi akan terjadi antara guru dan siswa, bergantung pada pola komunikasi yang terjadi antara keduanya (Noddings, 2001).

Ada tiga dimensi caring yaitu: 1) knowing; yang melibatkan kesadaran bahwa orang lain itu memiliki kebutuhan yang unik. Hal ini berimplikasi pada pemahaman akan kebutuhan, kekuatan, kelemahan, dan keterbatasan orang lain, 2) courage; mewujudkan kepedulian pada saat seseorang butuh berkembang akan tetapi hal itu tidak diketahui. Ia berani mengatakan apa yang diinginkan dan berani menanggung resiko apapun untuk dihadapi, 3) patience; merupakan hal yang mendasar dalam caring karena dengan patience seseorang mau memberikan waktu dan tempat untuk mengekspresikan dan mengeksplorasikan dirinya. Ia juga meyakini bahwa belajar butuh 
waktu, serta menyayangi dan mendukung orang lain untuk maju (N. Kongho, 1994)

Pengembangan caring yang ditulis oleh NKongho memiliki banyak implikasi pada dunia kesehatan dan profesi lainnya termasuk pendidikan. Menurutnya, sikap care itu mulitidimensional, melibatkan domain kognitif dan afektif. ${ }^{3}$ Selanjutnya ia mengatakan bahwa seseorang yang memiliki tingkat caring yang tinggi, maka ia bisa menjadi model bagi orang yang memiliki tingkat caring yang rendah. Ia juga menulis, bahwa kemampuan untuk care itu sangat penting diterapkan pada semua aspek situasi dan profesi daripada aspek yang lain. Caring ability inventory yang dikembangkan oleh NKongho memiliki implikasi yang berarti dalam dunia pendidikan. Ia mengatakan bahwa dimensi caring bisa diajarkan dan bisa digunakan untuk mengukur keberhasilan perilaku, karena caring termasuk perilaku.

Adapun strategi yang dapat dilakukan dalam menumbuhkan caring ada empat meliputi: 1) modeling yaitu guru menunjukkan pada siswa apa makna care pada orang lain sehingga siswa paham tidak hanya maknanya tapi juga 
bagaimana menjadikan diri mereka care untuk orang lain, 2) dialog yaitu melalui dialog guru dan siswa dekat satu sama lain, juga membangun kedekatan pengetahuan dengan siswa, 3) praktek yaitu guru memberikan kesempatan pada siswa untuk melakukan care pada orang lain. Tanpa mempraktekkan caring maka siswa tidak akan pernah belajar bagaimana menjadi individu yang care, 4) konfirmasi yaitu guru melihat kebaikan dari tiap individu siswa dan menemukan cara bagaimana menjaga kebaikan tersebut (Noddings, 1992)

Upaya peningkatan mutu pendidikan dipengaruhi oleh banyak faktor. Salah satu faktor yang paling penting adalah guru, karena hitam-putihnya proses belajar mengajar di dalam kelas banyak dipengaruhi oleh mutu gurunya. Guru dikenal sebagai 'hidden currickulum' atau kurikulum tersembunyi, karena sikap dan tingkah laku, penampilan profesional, kemampuan individual, dan apa saja yang melekat pada pribadi seorang guru, akan diterima oleh peserta didik sebagai rambu-rambu untuk diteladani atau dijadikan bahan pembelajaran. Bagi sebagian besar orangtua siswa, sosok pendidik atau guru masih dipandang 
sebagai wakil orangtua ketika anak-anaknya tidak berada di dalam keluarga. ${ }^{4}$

Untuk meningkatkan kualitas dan kuantitas kegiatan belajar mengajar yang dilakukan oleh guru sebagai tenaga kependidikan, maka profesi guru harus memiliki dan menguasai perencanaan kegiatan belajar mengajar, melaksanakan kegiatan yang direncanakan dan melakukan penilaian terhadap hasil dari proses belajar mengajar. Kemampuan guru dalam merencanakan dan melaksanakan proses pembelajaran merupakan faktor utama dalam mencapai tujuan pengajaran. Keterampilan merencanakan dan melaksanakan proses belajar mengajar ini sesuatu yang erat kaitannya dengan tugas dan tanggung jawab guru sebagai pengajar yang mendidik.

Guru sebagai pendidik mengandung arti yang sangat luas, tidak sebatas memberikan bahan-bahan pengajaran tetapi menjangkau etika dan estetika perilaku dalam menghadapi tantangan kehidupan di masyarakat. Sebagai pengajar, guru hendaknya memiliki perencanaan (planing) pengajaran yang cukup matang. Perencanaan pengajaran tersebut erat kaitannya 
dengan berbagai unsur seperti tujuan pengajaran, bahan pengajaran, kegiatan belajar, metode mengajar, dan evaluasi. Unsur-unsur tersebut merupakan bagian integral dari keseluruhan tanggung jawab guru dalam proses pembelajaran.(Palmer, 1994)

Secara umum terdapat beberapa langkah strategi yang dapat diimplementasikan dalam lingkungan kependidikan dengan tujuan bahwa peningkatan mutu pendidik dapat dilakukan melalui strategi- strategi berikut: 1) self assessment, 2) Perumusan Visi, Misi, dan tujuan, 3) Perencanaan, 4) Pelaksanaan, 5) evaluasi, dan 6) pelaporan. (Atmowidoro, 2000).

Kegiatan pembinaan dan pengembangan profesi dapat dilakukan oleh institusi pemerintah, lembaga pelatihan (training provider) nonpemerintah,penyelenggara, atau satuan pendidikan. Di tingkat satuan pendidikan, program ini dapat dilakukan oleh guru pembina, guru inti, koordinator guru kelas, dan sejenisnya yang ditunjuk dari guru terbaik dan ditugasi oleh kepala sekolah. Analisis kebutuhan, perumusan tujuan dan sasaran, desain program, implementasi dan layanan, serta evaluasi program pelatihan dapat ditentukan secara mandiri oleh penyelenggara atau memodifikasi/mengadopsi program sejenis. Dengan adanya pembinaan dan pengembangan karier dan profesionalitas, diharapkan para praktisi pendidikan tersebut dapat menjalankan 
fungsinya dengan baik sebagai pendidik bangsa, untuk mewujudkan masyarakat yang bermartabat dan berkualitas.

\section{Caring Relationship sebagai Pembentukan Karakter Anak Didik Dalam Tradisi Pembelajaran Jawa}

Pendidikan karakter senantiasa ada pada zamannya. Namanya berganti-ganti, mulai dari Civics dan Pendidikan Kewarganegaraan pada zaman Orde Lama. Pada masa Orde Baru menjadi Pendidikan Moral Pancasila (PMP) serta PPKn. Namanya memang berbeda, namun muatan dan orientasinya adalah Pedoman Penghayatan dan Pengamalan Pancasila (P-4), dengan pendekatan pembelajaran yang didominasi oleh pendekatan indoktrinatif teoritis.

Meskipun sudah ada materi-materi yang bermuatan tentang pengembangan moral anak, Namun kurikulum pendidikan di Indonesia yang ada selama masih belum menyentuh aspek karakter ini, meskipun ada pelajaran Pancasila, kewarganegaraan dan semisalnya,karena masih sebatas teori dan tidak dalam tataran aplikatif. Padahal jika Indonesia ingin memperbaiki mutu Sumber Daya Manusia dan segera bangkit 
dari ketinggalannya, maka Indonesia harus merombak sistem pendidikan yang ada saat ini.

Mungkin banyak yang bertanya-tanya sebenarnya apa dampak pendidikan karakter terhadap keberhasilan akademik ataupun kehidupan non akademik anak? Beberapa penelitian bermunculan untuk menjawab pertanyaan ini. Dalam sebuah buletin, Character Educator, yang diterbitkan oleh Character Education Partnership diuraikan hasil studi Dr. Marvin Berkowitz dari University of Missouri- St. Louis, yang menunjukan peningkatan motivasi siswa sekolah dalam meraih prestasi akademik pada sekolah-sekolah yang menerapkan pendidikan karakter. Kelas-kelas yang secara komprehensif terlibat dalam pendidikan karakter menunjukan penurunan drastis pada perilaku negatif siswa yang dapat menghambat keberhasilan akademik. Pendidikan karakter adalah pendidikan budi pekerti plus, yaitu yang melibatkan aspek pengetahuan (cognitive), perasaan (feeling), dan tindakan (action). Menurut Thomas Lickona, tanpa ketiga aspek ini, maka pendidikan karakter tidak akan efektif, dan pelaksanaannya pun harus dilakukan secara sistematis dan berkelanjutan. Dengan pendidikan karakter, seorang anak akan menjadi cerdas emosinya. Kecerdasan emosi 
adalah bekal terpenting dalam mempersiapkan anak menyongsong masa depan, karena dengannya seseorang akan dapat berhasil dalam menghadapi segala macam tantangan, termasuk tantangan untuk berhasil secara akademis. Sebuah buku yang baru terbit berjudul Emotional Intelligence and School Success (Joseph Zins, et.al, 2001) mengkompilasikan berbagai hasil penelitian tentang pengaruh positif kecerdasan emosi anak terhadap keberhasilan di sekolah. Dikatakan bahwa ada sederet faktor-faktor resiko penyebab kegagalan anak di sekolah. Faktorfaktor resiko yang disebutkan ternyata bukan terletak pada kecerdasan otak, tetapi pada karakter, yaitu rasa percaya diri, kemampuan bekerja sama, kemampuan bergaul, kemampuan berkonsentrasi, rasa empati, dan kemampuan berkomunikasi. Hal ini sesuai dengan pendapat Daniel Goleman tentang keberhasilan seseorang di masyarakat, ternyata 80 persen dipengaruhi oleh kecerdasan emosi, dan hanya 20 persen ditentukan oleh kecerdasan otak (IQ) (Daniel Golemen, 2007).

Anak-anak yang mempunyai masalah dalam kecerdasan emosinya, akan mengalami kesulitan belajar, bergaul dan tidak dapat mengontrol emosinya. Anak-anak yang bermasalah ini sudah dapat dilihat sejak usia pra-sekolah, dan kalau tidak 
ditangani akan terbawa sampai usia dewasa. Sebaliknya para remaja yang berkarakter atau mempunyai kecerdasan emosi tinggi akan terhindar dari masalah-masalah umum yang dihadapi oleh remaja seperti kenakalan, tawuran, narkoba, miras, perilaku seks bebas, dan sebagainya. Pendidikan karakter di sekolah sangat diperlukan, walaupun dasar dari pendidikan karakter adalah di dalam keluarga. Kalau seorang anak mendapatkan pendidikan karakter yang baik dari keluarganya, anak tersebut akan berkarakter baik selanjutnya. Namun banyak orang tua yang lebih mementingkan aspek kecerdasan otak daripada pendidikan karakter. Selain itu Daniel Goleman juga mengatakan bahwa banyak orang tua yang gagal dalam mendidik karakter anakanaknya entah karena kesibukan atau karena lebih mementingkan aspek kognitif anak. Namun ini semua dapat dikoreksi dengan memberikan pendidikan karakter di sekolah. Permasalahannya, kebijakan pendidikan di Indonesia juga lebih mementingkan aspek kecerdasan otak, dan baru-baru ini saja pentingnya pendidikan budi pekerti menjadi bahan kajian yang sering didiskusikan. Ada yang mengatakan bahwa kurikulum pendidikan di Indonesia dibuat hanya cocok untuk diberikan pada 10-20 persen otak-otak terbaik. Artinya sebagian besar anak sekolah (80-90 persen) tidak dapat mengikuti kurikulum 
pelajaran di sekolah. Akibatnya sejak usia dini, sebagian besar anak-anak akan merasa 'bodoh' karena kesulitan menyesuaikan dengan kurikulum yang ada. Ditambah lagi dengan adanya sistem ranking yang telah "memvonis" anak-anak yang tidak masuk ranking 10 besar, sebagai anak yang kurang pandai. Sistem seperti ini tentunya berpengaruh negatif terhadap usaha membangun karakter, dimana sejak dini anak-anak justru sudah "dibunuh" rasa percaya dirinya. Rasa tidak mampu yang berkepanjangan yang akan membentuk pribadi yang tidak percaya diri, akan menimbulkan stress berkepanjangan.

Pada usia remaja biasanya keadaan ini akan mendorong remaja berperilaku negatif. Maka, tidak heran kalau lihat perilaku remaja yang senang tawuran, terlibat kriminalitas, putus sekolah, dan menurunnya mutu lulusan SMP dan SMU. Jadi, pendidikan karakter atau budi pekerti plus adalah suatu yang urgent dan mendesak untuk dilakukan. Kalau masyarakat peduli untuk meningkatkan mutu lulusan SD, SMP dan SMU, maka tanpa pendidikan karakter adalah usaha yang sia-sia.

Mahatma Gandhi memperingatkan tentang salah satu tujuh dosa fatal, yaitu education without character (pendidikan tanpa karakter). Dr. Martin Luther King juga pernah berkata: 
Intelligence plus character....that is the goal of true education (Kecerdasan plus karakter....itu adalah tujuan akhir dari pendidikan sebenarnya). Juga Theodore Roosevelt yang mengatakan: To educate a person in mind and not in morals is to educate a menace to society (Mendidik seseorang dalam aspek kecerdasan otak dan bukan aspek moral adalah ancaman marabahaya kepada masyarakat).

Dunia pendidikan diharapkan sebagai motor penggerak untuk memfasilitasi pembangunan karakter, sehingga anggota masyarakat mempunyai kesadaran kehidupan berbangsa dan bernegara yang harmonis dan demokratis dengan tetap memperhatikan norma-norma di masyarakat yang telah menjadi kesepakatan bersama.Pembangunan karakter dan pendidikan karakter menjadi suatu keharusan karena pendidikan tidak hanya menjadikan peserta didik menjadi cerdas, juga mempunyai budi pekerti dan sopan santun sehingga keberadaannya sebagai anggota masyarakat menjadi bermakna baik dirinya maupun orang lain. Pembinaan karakter harus dilakukan pada semua tingkat pendidikan hingga Perguruan Tinggi (PT) karena PT harus mampu berperan sebagai mesin informasi yang membawa 
bangsa ini menjadi bangsa yang cerdas, santun, sejahtera dan bermartabat serta mampu bersaing dengan bangsa manapun.

\section{Caring Relationship sebagai Salah Satu Bentuk Pendidikan Karakter}

Caring relationship sangat penting dimiliki oleh guru untuk menciptakan hubungan yang bermakna antara guru dan siswa dalam lingkungan yang nyaman dan mendukung. Caring tidak cukup diucapkan dengan kata-kata tanpa aksi nyata. (Nell Nodding; 1984)Terkadang seseorang berkata 'aku sangat care' pada 'sesuatu' namun sejatinya dia belum melakukannya, karena dalam aktifitisnya belum menunjukkan sikap 'care' tersebut. Nodding juga menulis, praktik dalam mengajar seharusnya juga mempraktekkan Caring. Secara luas, caring juga diyakini sebagai hal yang pokok dalam pembelajaran. (Lisa S. Goldstein \& Vickie E. Lake, 1999) Roger dan Webb menegaskan bahwa pembelajaran yang baik tidak dapat dilepaskan dari aktifitas spesifik yaitu Caring. (Roger \& Webb; 1991)

Guru perlu menyadari makna penting 'Caring' dalam mengelola kelas, karena ia memiliki dampak luas terhadap academic and Social achievement siswa. Satu contoh, seorang 
anak pulang dari sekolah berteriak ketika sampai di rumah.Dia mengeluarkan kata-kata benci ibu guru karena ibu gurunya tidak memperdulikannya, ibu guru tidak adil dengan tugas yang dikerjakan dan lain sebagainya. Akibatnya ia jadi malas ke sekolah, karena ia merasa sudah belajar dan mengerjakan dengan benar apa yang ditugaskan. Bila ditelusur, ini bermula dari 'caring relationship' yang tidak dimiliki oleh guru dan guru tidak memahami bagaimana memperlakukan itu semua.

Satu contoh lagi, seorang siswa tidak paham pelajaran Matematika meskipun guru sudah menjelaskan secara detil terhadap semua siswa. Tanpa sadar guru berkata 'kamu memang tidak suka Matematika' sehingga kamu tetap saja tidak bisa. Katakata ini justru akan semakin membuat siswa down, karena dia sudah diberi stigma pembenci Matematika. Padahal ketika guru memiliki 'caring relationship' dia akan mengatakan 'kamu harus belajar menyenangi pelajaran matematika' dan guru senantiasa mensupport saat dibutuhkan si anak belajar pelajaran tersebut, sampai si anak menjadi lebih baik.(Nell Nodding, 1984) Guru merasa nyaman, sakit, dan dekat pada anak dan punya komitmen untuk melakukan hal tersebut pada saat siswa butuh. Maka pengembangan Caring menjadi hal yang penting pula bagi 
pendidikan calon guru untuk mewujudkan pembelajaran yang efektif dan profesional.

Dalam beberapa tahun, memahami pengelolaan kelas yang efektif selalu mengacu pada teori-teori behavioral tentang pembelajaran dan pengajaran. Penekanan utama untuk pengelolaan kelas dalam behavioral model adalah penggunaan teknik-teknik tentang stimulus kontrol terhadap perilaku siswa. Behavioral model ini menekankan pada reward dan penalti pada siswa. (Brophi, 1999).

Sebaliknya, akhir dekade ini ada sebuah dorongan untuk menggeser pendekatan-pendekatan kontrol behavior dengan mengimplementasikan pendekatan-pendekatan yang berfokus pada relationship dan pengembangan komunitas Caring (Power, Higgins, \& Kohlbert,1989)

Pendekatan yang berfokus pada Caring ini bermula pada penelitian tentang 'persepsi siswa tentang guru yang baik'. Beberapa tahun kemudian hasil penelitian menunjukkan bahwa persepsi siswa tentang 'guru yang baik' adalah guru yang memiliki sikap prososial, perilaku yang bertanggung jawab, taat pada 
norma dan aturan kelas, serta mendorong pada aktifitas-aktifitas akademik. (Osterman, 2000;Wentzel, 1997).

Namun, apa makna sesungguhnya 'good teacher' itu? Menurut Woolfolk Hoy dan Weinstein (2006) ada tiga faktor utama persepsi siswa tentang 'good teacher' yaitu; kemampuan untuk menjalankan otoritas dengan tidak sangat kaku, kemampuan untuk membuat pembelajaran lebih menyenangkan, kemampuan positif membangun 'caring interpersonal relathionship'.

Salah satu faktor sosial yang terjadi dalam kelas adalah relationship yang terjadi antara guru dan siswa. Jika relationship yang terjadi adalah Caring relationship, maka siswa akan sangat beruntung pada aspek akademis dan sosialnya.(Brandelyn Tosolt, 2009).Agar siswa dapat menerima manfaat ini, baik guru maupun siswa harus sama-sama memiliki caring relationship.

Menurut Nodding (2005) Caring relationship dapat terjadi dalam hubungan dua orang, dan ini adalah sebuah aspek dari komunikasi. Komunikasi berakar pada bahasa, baik verbal maupun nonverbal (Martin \&Nakayama, 2000).Jika terjadi komunikasi antara dua orang dengan dua bahasa yang berbeda, 
maka mereka akan memiliki dua cara memaknainya dengan cara yang berbeda. Miskomunikasi akan terjadi antara guru dan siswa, bergantung pada pola komunikasi yang terjadi antara keduanya.

Caring relationship guru banyak didiskusikan oleh para peneliti (Cutforth, 1999) ditemukan bahwa murid merasa diperlakukan care oleh guru dengan cara menjaganya dengan kontrol yang tinggi. Sedangkan Rogers (1994) menyatakan bahwa murid mendapat perlakuan care guru dengan cara guru menunjukkan concernnya terhadap prestasi akedemik, sosial, dan fisik yang menjadi lebih baik. Berbeda dengan Howard (2001), dia memposisikan guru yang memiliki caring relationship adalah guru yang mampu menciptakan lingkungan kelas yang nyaman sehingga siswa betah di kelas melalui perilaku yang ditunjukkan oleh guru, seperti menepuk punggungnya dan lainnya.

Pada tahun 2005, Ruggiero menemukan bahwa caring relationship yang ditunjukkan oleh guru diantaranya; guru memberikan feedback positif, membantu siswa keluar dari permasalahannya, sensitif terhadap emosi siswa, dan memberikan kenyamanan pada siswa. (Ruggiero; 2005). 
Sebuah penelitian dilakukan oleh Mary Allice dan John Stellern yang mengembangkan Caring Community di lembaga pendidikan Guru. Dalam penelitiannya menghasilkan temuan bahwa Caring sangat berpengaruh dan dapat menyelesaikan problem pribadi, keluarga, dan etnik dan problem kelas, sehingga dapat menciptakan pembelajaran, pengajaran dan kehidupan yang efektif.(Mary allice \& John Stellern, 2005)

Nell Noddings dalam bukunya Caring A Feminine Approach to Ethics \& Moral Education menjelaskan bahwa untuk Care adalah melakukan sesuatu bukan karena aturan yang ketat, tapi dengan sikap dan penghargaan (Noddings, 1984). Ketika guru 'Care' maka ia mempertimbangkan pandangan siswa, kebutuhan objektifnya, dan apa yang diharapkannya. Caring melibatkan perasaan terhadap orang lain, hubungan ini bisa disebut juga dengan empathy. Dalam Oxford Dictionary, empathy didefinisikan sebagai kekuatan personality seseorang dan penuhnya pengertian terhadap yang lain. Seperti contoh; ketika guru berkomunikasi dengan siswa, maka ia menjadi pendengar yang baik, matanya merefleksikan keseriusan, humor, dan senang dengan pesan-pesan dalam pembicaraan. 
Dengan istilah lain Noddings mengatakan bahwa to care adalah memberikan proteksi, 'kesejahteraan' pada sesuatu atau seseorang. Guru dianggap care jika ia menghargai pandanganpandangan siswa dan ketertarikannya. Guru juga membantu siswa untuk berkembang dan mengaktualisasikan dirinya. Caring dibutuhkan komitmen. Pada saat mengetahui kenyataan bahwa dia harus melakukan, mengurangi rasa sakit, memenuhi kebutuhan, dan mengaktualisasikan mimpi anak. Caring mengacu pada dua hal, yaitu; aktualitas dan komitmen secara verbal (Noddings; 1984)

Caring terdiri dari 4 komponen, menurut Noddings, yaitu; Modeling, dialog, praktek, dan konfirmasi. Modeling yaitu guru menunjukkan pada siswa apa makna care pada orang lain sehingga siswa paham tidak hanya maknanya tapi juga bagaimana menjadikan diri mereka care untuk orang lain. Dialog yaitu melalui dialog, guru dan siswa dekat satu sama lain. Dialog membangun kedekatan pengetahuan dengan yang orang lain. Praktek yaitu guru memberikan kesempatan pada siswa untuk melakukan care pada orang lain. Tanpa mempraktekkan caring maka siswa tidak akan pernah belajar bagaimana menjadi individu yang care. Konfirmasi yaitu guru melihat kebaikan dari 
tiap individu siswa dan menemukan cara bagaimana menjaga kebaikan tersebut.(Nell Noddings, 1992)

Gambaran di atas menunjukkan bahwa hubungan positif yang diciptakan oleh guru akan memberikan efek positif kepada anak didik karena merekapun akan melakukan hal serupa kepada orang lain ketika modeling yang diterima adalah good model. Maka Caring relationship yang diciptakan oleh guru terhadap anak akan membentuk karakter positif dalam kehidupan akademik maupun kehidupan sosial anak.

\section{E. Membangun Pendidikan Karakter Integratif}

Maka saatnya disadari bahwa karakter merupakan titian ilmu pengetahuan dan keterampilan. Pengetahuan tanpa landasan kepribadian yang benar akan menyesatkan dan keterampilan tanpa kesadaran diri akan menghancurkan. Karakter itu akan membentuk motivasi, dan pada saat yang sama dibentuk dengan metode dan proses yang bermartabat. Karakter bukan sekadar penampilan lahiriah, melainkan secara implisit mengungkapkan hal-hal tersembunyi. Karakter yang baik mencakup pengertian, kepedulian, dan tindakan berdasarkan nilai-nilai etika, meliputi aspek kognitif, emosional, dan perilaku dari kehidupan moral.

Membangun karakter dari pintu pendidikan harus dilakukan secara komprehensif-integral, tidak hanya melalui pendidikan formal, namun juga melalui pendidikan informal dan 
non formal. Selama ini, ada kecenderungan pendidikan formal, informal dan non formal berjalan terpisah satu dengan yang lainnya. Akibatnya, pendidikan karakter seolah menjadi tanggung jawab secara parsial.Banyak hal yang memiriskan ketika mengamati sistem pendidikan kita. Di depan mata, nilai-nilai kejujuran telah diinjak-injak. Mencontek, menjiplak karya orang lain, melakukan sabotase, adalah hal yang sering terjadi dan dianggap biasa.

Pendidikan yang ada selama ini sepertinya lebih banyak menghasilkan generasi yang pandai mengeluh, membebek, dan mengambil jalan pintas. Untuk menanamkan nilai kejujuran misalnya, sekolah ramai-ramai membuat kantin kejujuran. Anak diajak untuk jujur dalam membeli dan membayar barang yang dibeli tanpa ada yang mengontrolnya.Namun sayang, gagasan yang tampaknya relevan dalam mengembangkan nilai kejujuran ini mengabaikan prinsip dasar pedagogi pendidikan berupa kedisiplinan sosial yang mampu mengarahkan dan membentuk pribadi anak didik.

Demikian juga perilaku masyarakat banyak yang memberi contoh kurang mendidik seperti perilaku kurang sopan, mencuri, dan yang lainnya. Secara institusional, Pemerintah hendaknya memasukkan pendidikan budaya dan karakter bangsa melalui penguatan kurikulum, mulai dari tingkat sekolah dasar hingga perguruan tinggi, sebagai bagian dari penguatan sistem pendidikan nasional. 
Hal ini penting dilakukan agar nilai-nilai budaya dan karakter bangsa itu tetap melekat pada diri anak sehingga tidak terjadi lost generation dalam hal budaya dan karakter bangsa.Keluaran (output) pendidikan harus direorientasi pada keseimbangan tiga unsur pendidikan berupa karakter diri, pengetahuan, soft skill. Jadi bukan hanya berhasil mewujudkan anak didik yang cerdas otak, tetapi juga cerdas hati, dan cerdas raga.

Lickona (2007) menyatakan: terdapat 11 prinsip agar pendidikan karakter dapat berjalan efektif: (1) kembangkan nilainilai etika inti dan nilai-nilai kinerja pendukungnya sebagai fondasi, (2) definisikan "karakter" secara komprehensif yang mencakup pikiran, perasaan, dan perilaku, (3) gunakan pendekatan yang komprehensif, disengaja, dan proaktif, (4) ciptakan komunitas sekolah yang penuh perhatian, (5) beri siswa kesempatan untuk melakukan tindakan moral. Berikutnya, (6) buat kurikulum akademik yang bermakna dan menantang yang menghormati semua peserta didik, mengembangkan karakter, dan membantu siswa untuk berhasil. (7) Usahakan mendorong motivasi diri siswa, (8) libatkan staf sekolah sebagai komunitas pembelajaran dan moral, (9) tumbuhkan kebersamaan dalam kepemimpinan moral, (10) libatkan keluarga dan anggota masyarakat sebagai mitra, dan (11) evaluasi karakter sekolah, fungsi staf sekolah sebagai pendidik karakter, dan sejauh mana siswa memanifestasikan karakter yang baik.

Agar dapat berjalan efektif, pendidikan karakter dapat 
dilakukan melalui tiga desain, yakni; (1) Desain berbasis kelas, yang berbasis pada relasi guru sebagai pendidik dan siswa sebagai pembelajar, (2) Desain berbasis kultur sekolah, yang berusaha membangun kultur sekolah yang mampu membentuk karakter anak didik dengan bantuan pranata sosial sekolah agar nilai tertentu terbentuk dan terbatinkan dalam diri siswa, dan (3) Desain berbasis komunitas.

Dalam mendidik, komunitas sekolah tidak berjuang sendirian. Masyarakat di luar lembaga pendidikan, seperti keluarga, masyarakat umum, dan negara, juga memiliki tanggung jawab moral untuk mengintegrasikan pembentukan karakter dalam konteks kehidupan mereka.

Dengan desain demikian, pendidikan karakter akan senantiasa hidup dan sinergi dalam setiap komponen pendidikan. Sejak anak lahir atau bahkan masih dalam kandungan, ketika berada di lingkungan sekolah, kembali ke rumah, dan bergaul dalam lingkungan sosial masyarakatnya, akan selalu menjadi tempat bagi anak-anak untuk belajar, mencontoh, dan mengaktualisasikan nilai-nilainya yang dipelajari dan dilihatnya itu. 


\section{BAB VIII}

\section{KOMUNIKASI VERBAL DAN NON VERBAL DALAM PEMBELAJARAN}

Manusia adalah makhluk sosial. Ia hanya dapat hidup dan berkembang, dan berperan sebagai manusia dengan berhubungan dan bekerjasama dengan manusia lain. Seringkali konflik komunikasi menghambat seseorang untuk mengembangkan dunia sosialnya secara matang. Akibat dari hal ini, ia merasa kesepian, merasa tidak berharga, dan suka mengisolasi diri. Pada akhirnya ia mudah depresi dan kehilangan kebermaknaan hidup.

Setiap orang membutuhkan orang lain untuk memenuhi kebutuhan sosialnya. Dari interaksi sosialnya mereka dapat memenuhi kebutuhan akan perhatian, kasih sayang dan cinta. Untuk itulah teman dan lingkungan sosial yang mendukung menjadi penentu kematangan psikologis seseorang. Goleman telah menggulirkan kecerdasan sosial menjadi salah satu bentuk kecerdasan yang menentukan kehidupan seseorang (Social Intelligence, 2006), menurutnya, relasi sosial dapat memberikan dampak yang sangat berarti bagi pribadi seseorang baik secara psikhis maupun fisiknya. Karena kecerdasan sosial tidak hanya diartikan sebagai 'hubungan' seseorang dengan orang lain, namun makna dari 'hubungan' itu sendiri. Lingkup kecerdasan sosial ini mendorong seseorang untuk memperkaya relasi pribadi, seperti empati dan kepedulian. Bentuk nyata dari kecerdasan 
sosial ini diantaranya mampu berkomunikasi secara 'cerdas' dengan orang lain.

Dalam proses belajar mengajar tidak lepas dari komunikasi, maka komunikasi efektif menjadi bagian yang sangat penting dalam pembelajaran. Hal ini karena proses belajar mengajar melibatkan aktivitas komunikasi antara siswa dan guru, juga dengan stakeholder lainnya. Verbal dan non verbal communication merupakan aspek yang perlu mendapat penekanan bagi setiap guru, karena guru menggunakan perkataan untuk menyampaikan bahan kepada siswa secara lisan, dan menurut Moore (2001) terkadang guru menyampaikannya lewat gesture, ekspresi wajah, kontak pandang, penampilan dan lain sebagainya.

\section{A. Komunikasi Verbal dan Non Verbal Pembelajaran}

Kepribadian terbentuk sepanjang hidup manusia. Selama itu pula komunikasi menjadi penting untuk pertumbuhan pribadi. Melalui komunikasi seseorang akan menemukan dirinya, mengembangkan konsep diri dan menetapkan hubungan dengan dunia sekitar. Hubungan dengan orang lain akan menentukan kualitas hidup seseorang. Bila orang lain tidak memahami gagasan seseorang, bila pesan orang lain menjengkelkan seseorang, bila semakin sering berkomunikasi ternyata semakin membuat jauh jarak dengan orang lain, bila seseorang selalu gagal 
mendorong orang lain bertindak, ini menunjukkan bahwa sesorang telah gagal berkomunikasi (Jalaluddin Rakhmad, 2009)

Begitu juga bagi guru, dalam transfer pembelajaran ia dituntut untuk memiliki kamampuan berkomunikasi yang efektif, karena kemampuan komunikasi guru menjadi salah satu penentu kesuksesan anak didik dalam pembelajaran. Seorang pendidik yang efektif tidak hanya efektif dalam kegiatan belajar mengajar di kelas saja (transfer of knowledge), tetapi lebih-lebih dalam relasi pribadinya dan "modeling"nya (transfer of attitude and values), baik kepada peserta didik maupun kepada seluruh anggota komunitas sekolah. Pendidikan yang humanis menekankan bahwa pendidikan pertama-tama dan yang utama adalah bagaimana menjalin komunikasi dan relasi personal antara pribadi-pribadi dan antar pribadi dan kelompok di dalam komunitas sekolah. Relasi ini berkembang dengan pesat dan menghasilkan buah-buah pendidikan jika dilandasi oleh cinta kasih antar mereka. Pribadi-pribadi hanya berkembang secara optimal dan relatif tanpa hambatan jika berada dalam suasana yang penuh cinta (unconditional love), hati yang penuh pengertian (understanding heart) serta relasi pribadi yang efektif (personal relationship). Dalam mendidik seseorang guru hendaknya mampu menerima diri sebagaimana adanya dan kemudian mengungkapkannya secara jujur (modeling). Mendidik tidak sekedar mentransfer ilmu pengetahuan, melatih keterampilan verbal kepada para peserta didik, namun 
merupakan bantuan agar peserta didik dapat menumbuhkembangkan dirinya secara optimal.

Menurut Mohd. Safar dan Fatimah (1988) komunikasi verbal dan non verbal merupakan satu kesatuan yang tidak dapat dipisahkan. Antara satu dan lainnya berkaitan dalam menyampaikan suatu pesan. Maka, dalam melaksanakan proses pembelajaran guru harus mampu menggabungkan kedua jenis komunikasi ini. Kemampuan guru dalam mengaplikasikannya dapat membantu meningkatkan kesan dalam proses belajar mengajar. Pogue dan Kimo (2006) berpendapat bahwa proses belajar mengajar yang berkesan adalah hasil dari hubungan komunikasi antara guru dan siswa serta kredibilitas seorang guru. Hal ini menunjukkan bahwa hubungan guru-siswa dan sikap guru terhadap kerja sangat penting dalam meningkatkan perilaku yang positif.

Komunikasi merupakan manifestasi dari attitude yang akurat dan terbuka dalam perubahan informasi. Komunikasi merupakan inti dari kreativitas dan menjaga sekolah agar berjalan efektif. Komunikasi yang terjadi di sekolah sangat krusial dalam membentuk realitas sosial guru. Sedangkan menurut Bekewell (1988) dan Kyriacou dan Sutcliffe (1978), hubungan guru dan 
siswa memiliki pengaruh yang signifikan terhadap tingkat stres siswa. Guru yang berkomunikasi secara efektif dengan siswa akan sangat membantu siswa dalam belajar, juga interaksi antara guru-siswa sangat menentukan kesuksesan hubungan selama mereka belajar di sekolah.

Tantangan budaya merupakan tantangan dalam berkomunikasi. Gay (2002) berpendapat bahwa siswa yang paham dan dapat melakukan sesuatu dengan baik, tergantung bagaimana guru dapat berkomunikasi dengan mereka. Taylor (1990) sangat yakin bahwa komunikasi merupakan dimensi yang esensi dalam menciptakan pendidikan yang efektif. Fortujin (2002) meneliti bahwa problem dalam berbahasa adalah problem dalam pemahaman, dan bahasa tersebut mencakup 'menemukan kata yang tepat, corak suara yang tepat, dan nuansa yang tepat; hal tersebut terkait dengan permasalahan pronounciation dan kemampuan mendengar, kecepatan, nada, dan tune.

Di Amerika, menurut White (2000), pronounciation merupakan faktor penting dalam berkomunikasi, penggunaan pronounciation yang tepat akan membantu siswa respek dan percaya diri pada guru. Di Negara-negara Asia, 'fenomena saving face' dan 'losing face' sebagai bentuk pernyataan komunikasi 
tidak langsung. Pada kondisi ini, siswa menunjukkan bahwa dia sudah paham sesuatu padahal sebenarnya tidak. Hal ini karena respon siswa menunjukkan mereka yang tidak paham boleh merefleksikan secara negatif pada siswa dan guru. Sedangkan komunikasi non verbal menurut White (2000) dan Taylor (1990), merupakan komunikasi yang sangat penting karena menunjukkan kredibilitas dan leadership guru. Ada 6 faktor dalam komunikasi non verbal yang terkait dengan pengajaran efektif, yaitu; kontak pandang, gesture, paralanguage, posture, pakaian dan lingkungan, serta ekspresi wajah.

Guru adalah role model bagi siswa, baik di dalam maupun di luar kelas. Sava (2001) mengatakan, perilaku guru yang kurang positif dapat menimbulkan beberapa efek negatif pada siswa. Hsiao \& Darrel menyatakan bahwa interaksi di kelas antara guru dan siswa berlangsung sangat cepat. Sedangkan Good dan Brophy (1991) memprediksi bahwa guru Sekolah Dasar berinteraksi dengan 150 siswa yang berbeda setiap harinya. Namun, seringkali guru tidak peduli atau tidak dapat menjelaskan atau bahkan mengingat apa yang terjadi dalam interaksi bersama muridnya. Misalnya, guru biasanya tidak peduli berapa pertanyaan yang sudah diberikan kepada siswa-siswanya, dan 
bagaimana umpan balik yang disampaikan siswa. Maka dari itu guru harus memahami bahwa perilaku dan interaksi mereka dalam pembelajaran bisa diidentifikasi dan dicatat.

Beberapa peneliti di Nederland (Wubbels, Creton, \& Holvast, 1988, Wubbels, Creton \& Hoomayers, 1992; Wubbels \& Levy, 1993) meneliti perilaku guru dalam kelas dengan mengadaptasi teori proses komunikasi yang dikembangkan oleh Waltzlawick, Beavin, dan Jackson. Dengan system perspektif komunikasi, dapat diasumsikan bahwa perilaku seseorang dipengaruhi oleh perilaku orang lain. Perilaku guru juga dipengaruhi oleh perilaku siswa, maka, proses putaran komunikasi berkembang. Pendekatan sistem ini mengasumsikan bahwa seseorang tidak dapat berkomunikasi tanpa kehadiran yang lainnya.

\section{B. Komunikasi Non Verbal dalam Pembelajaran}

Kualitas guru menjadi faktor penting dalam kesuksesan siswa. Salah satu kualitas yang harus dimilikinya adalah guru harus memiliki sosial skill yang baik sehingga siswa bisa berkomunikasi dengan baik kepadanya. Keterampilan sosial ini dibutuhkan setiap orang dalam berinteraksi dan berkomunikasi dengan yang lainnya. Ada cara komunikasi verbal dan nonverbal. 
Komunikasi verbal mencakup berbicara pendek, berdiskusi, sharing lelucon dan ide. Untuk komunikasi nonverbal mencakup; mendengar aktif, yaitu mendengar dengan penuh empati dan ini terdaftar sebagai keterampilan sosial yang baik. Guru harus mendengar dengan hati-hati pada siswanya. Guru juga harus mendengar 'pembicaraan' siswanya dengan teman-teman sekelasnya. Di samping itu, bahasa tubuh juga termasuk komunikasi non verbal. Ini menjadi bagian penting dalam komunikasi, karena 50\% lebih digunakan dalam komunikasi. Maka guru harus memiliki keterampilan komunikasi verbal dan nonverbal yang baik dengan siswanya, membujuk, menyelesaikan masalah, dan memotivasi mereka.

Guru yang memiliki keterampilan sosial baik, akan tampak melalui bahasa tubuh dan bahasa oralnya. Guru harus memiliki kemampuan menjelaskan sehingga siswa secara jelas memahami apa yang disampaikan guru. Maka dari itu, hal ini akan menjadikan proses belajar mengajar lebih efektif. Sebagai tambahan, guru yang memiliki keterampilan sosial yang baik akan mudah menyelesaikan masalah siswa dan memotivasinya. Mereka memiliki kesadaran sosial dan kemampuan memahami 
dan memprediksi perilaku dan perasaan siswa. Maka, keterampilan sosial menjadi salah satu kriteria kualitas guru.

Untuk mendapatkan data tentang perilaku nonverbal guru, Van Tartwijk (1993) mengembangkan instrumen obeservasi kelas. Nonverbal behavior yang diukur salah satunya ekspresi wajah guru, sebagaimana yang diterima siswa adalah aspek yang sangat penting untuk menentukan tingkat kooperatif interpersonal guru.

Penelitian lain menunjukkan bahwa perilaku guru dapat memberikan efek pada prestasi siswa. (Good \& Broophy, 1974; Walberg, 1984). Menurut penelitian ini, pertanyaan yang diberikan oleh guru dan jawaban siswa adalah faktor utama menunjukkan bagaimana interaksi antara guru dan siswa terjadi dalam kelas. Eva Jarosova, Ljubica, Back-Tomic, Sanja Sikic dalam jurnalnya yang berjudul An Intervension Program for Developing the Interpersonal and Communication Skills of University Students mendukung tentang program strategi intervensi untuk mengembangkan keterampilan interpersonal dan komunikasi yang menghasilkan konsep bahwa self efficacy menjadi kata penting dalam mengembangkan keterampilan tersebut. Strategi intervensi yang digunakan adalah experiential 
learning karena experiential learning merupakan sebuah proses pembelajaran yang terintegrasi, dengan 4 tahapan; having a concrete experience, observation and reflections, formulating of abstract concepts and generalizations, and testing implications of the concepts in new situations in a different context. (Kolb, Rubin, Osland, 1991). Experiential learning dapat meningkatkan Self Efficacy melalui interaksi sosial (Bandura, 1993) Menurut Bandura (1995), self efficacy didefinisikan kemampuan seseorang dalam menghadapi situasi.

How do Teacher Communicate? Adalah sebuah artikel yang menyuguhkan konsep bagaimana mengevaluasi komunikasi yang dilakukan guru. Untuk menjawab itu, maka digunakan tes performen guru dengan 12 kategori komunikasi, yaitu; penggunaan bahasa oral, kefasihan, umpan balik, mekanisme berbicara, keluasan pengetahuan, kemampuan menjelaskan, menegaskan, memerintahkan, bertanya, menerima ide siswa, interaksi dengan orang tua, antusiasme, dan komunikasi nonverbalnya. Tidak semua negara menggunakan kriteria ini. Dalam beberapa kasus digunakan dengan kriteria sama, dan terkadang menggunakan kriteria berbeda. 
Dalam jurnal Essential Skills for Middle School Teachers, dijelaskan konsep tentang keterampilan kerjasama dan keterampilan komunikasi antar person merupakan keterampilan dasar yang dibutuhkan untuk membantu guru, tidak hanya menyelesaikan beberapa faktor stressor yang terjadi pada guru tetapi juga untuk keberhasilan dalam menghadapi lingkungan baru.

Di Pakistan, non verbal belum disadari urgensinya oleh para guru dan praktisi pendidikan lainnya. Namun saat ini para guru muda di Pakistan berpihak terhadap inovasi dan refleksi pembelajaran serta mencoba menemukan pentingnya komunikasi non verbal bagi guru. Padahal, dengan komunikasi non verbal guru dapat lebih enjoy dan menghemat energy dalam berkatakata. Siswa juga dapat terlibat dan termotivasi serta mendapatkan kebebasan dalam proses diskusi dalam kelas.

Komunikasi non verbal merupakan proses sharing makna yang multi-interpretatif dan tipe komunikasi yang unik. Ia bersifat natural, reliable dan spontan. Komunikasi memainkan peranan yang sangat signifikan dalam komunikasi interpersonal dan sangat penting bagi guru yang secara langsung berkomunikasi dengan siswa di kelas. Keterampilan komunikiasi non verbal 
yang harus dikuasai guru diantaranya; body language, penggunaan kontak pandang, jarak berdiri dengan siswa, sentuhan. Menurut Balzer, dalam sebuah penelitiannya menyebutkan, bahwa pengelolaan kelas hampir $75 \%$ menggunakan non verbal.

Research menunjukkan, komunikasi non verbal menjadi salah satu yang terbanyak secara budaya dipengaruhi oleh perilaku. Maka dari itu, kajian komunikasi non verbal seharusnya masuk dalam kurikulum pembelajaran sebagai perbedaan peran antar budaya yang signifikan ketika anggota salah satu budaya mempelajari bahasa yang lain. (Osterloh, 1986). Perbedaan orang Jepang dan non Jepang dalam menggunakan komunikasi non verbal dalam pembelajaran menjadi salah satu aspek penting untuk mengajar siswa jika menggunakan komunikasi dalam bahasa inggris secara efektif.

Kesadaran menggunakan komunikasi nonverbal menyumbangkan kesadaran antarkebudayaan dalam berkomunikasi, tidak hanya dengan native speaker tapi juga nonnative speaker dari negara lain yang memiliki latar belakang budaya yang berbeda. Komunikasi nonverbal memainkan peranan penting dalam interaksi sosial manusia. Meskipun begitu, 
fenomena komunikasi nonverbal hampir tidak pernah diteliti. Namun akhir-akhir ini Nonverbal aspects of Teacher-Pupil Communication in the Foreign Language Classroom barbagai disiplin ilmu mulai tertarik untuk mengkajinya. Mulai dari disiplin ilmu antropologi, ekonomi, bahasa, dan pendidikan. Disimpulkan bahwa sinyal-sinyal nonverbal memainkan peranan yang sangat tinggi dan memiliki peran esensi dalam komunikasi kelas.

Objek komunikasi nonverbal berbeda antar penulis. Menurut Argyle (1972), yang termasuk komunikasi nonverbal yaitu; kontak badan, postur, kedekatan, gerakan badan dan mimik, fisik, pandangan, emosi suara saat berbicara, kesalahan berbicara, aksen. Sedangkan menurut Knapp (1972) adalah; gerakan, karakteristik fisik, sentuhan, kedekatan, artifak, dan faktor lingkungan.

Menurut Dilek \& Steve dalam jurnal nonverbal communication lesson, menyajikan bagaimana mengajarkan komunikasi nonverbal. Di bawah ini teknik-teknik yang dapat digunakan untuk mengajarkan komunikasi nonverbal, yaitu: 
1. Para pebelajar diajak berdiskusi tentang makna gerak isyarat (gesture) dan ekspresi (didemonstrasikan oleh guru, melalui gambar, atau dari bahan lainnya)

2. Pebelajar meniru baik secara fisik maupun emosi.

3. Pebelajar diajak menonton video klip tanpa suara, mendiskusikan bahasa tubuh, hubungan, emosi dan perasaan, kemudian menulis dialog.

4. Pebelajar memperagakan dialog dengan menggunakan gerak isyarat dan ekspresi saja.

5. Pebelajar memoles dialog berdasarkan hasil meniru.

6. Pebelajar, secara berpasangan, mendengarkan satu sama lain selama 30 menit, hanya menggunakan respon nonverbal.

Steve Darn menjelaskan bahwa menggunakan komunikasi nonverbal yang efektif dalam kelas harus menambahkan ekstra bahasa, yaitu: mengurangi waktu berbicara yang tidak penting, meningkatkan partisipasi siswa, membangun percaya diri, mengurangi rasa takut untuk diam, memberikan petunjuk yang jelas, pengelolaan kelas yang efesien, menciptakan atmosphere kelas, meningkatkan keterampilan mendengar, meningkatkan performen dalam kegiatan berpasangan atau kelompok, saling mengkoreksi diri dan teman, menghindari kesalahpahaman, dan meningkatkan kompetensi antar budaya. 
Maka, guru harus selalu ingat bahwa gerak isyarat (gesture) dan insyarat nonverbal lainnya perlu untuk diajarkan dalam kelas. Yakinkan bahwa siswa mengerti sandi-sandi, dan ajarkan siswa untuk menggunakan sandi-sandi tersebut.

\section{Komunikasi Verbal dalam Pembelajaran}

Guru adalah orang yang selalu memberikan penjelasan. Menjelaskan biasanya merupakan proses verbal. Guru yang baik adalah guru yang menjadi role model dalam berbicara yang tepat dan memiliki keterampilan menulis yang baik. Guru juga dituntut untuk memahami komunikasi verbal siswa dan mampu membantu siswa meningkatkan kemampuan verbal mereka.

Menurut Andrew, et.al., bahwa kemampuan verbal mengacu pada kecakapan seseorang untuk memanfaatkan ide melalui kata-kata, baik lisan maupun tulisan. Kecakapan ini melibatkan kekayaan tidak hanya kuat secara vocabulary juga kemampuan untuk memilih kata yang tepat untuk memberikan makna pada audien. Kemampuan verbal juga menyangkut kemampuan untuk mengorganisir kata-kata dengan cara yang 
logis. Kemampuan verbal merupakan bagian dari konstruksi tradisional kecerdasan.

Secara umum, kemampuan verbal yang dikuasai guru adalah:

1. Jelas dalam memyampaikan informasi

2. Memberikan penjelasan yang jelas

3. Membantu siswa untuk menggunakan idenya dalam kata-kata

4. Membantu siswa meningkatkan keterampilan komunikasinya

5. Membantu siswa untuk memahami arti bahasa tulisan

6. Mampu menggunakan analogi dalam pembelajaran

7. Berkomunikasi secara baik dengan orang tua baik secara lisan maupun tulisan

8. Berkomunikasi secara efektif dengan tenaga administrasi.

Komunikasi verbal dan non verbal guru memiliki peran besar dalam menunjang keberhasilan pendidikan. Guru yang memahami tentang pentingnya komunikasi ini akan mampu menjadi pendidik yang berkualitas.

\section{BAB IX}




\section{KOMUNIKASI INTERPERSONAL DALAM PEMBELAJARAN}

\section{A. Pengertian Komunikasi Interpersonal}

Ada beberapa definisi komunikasi interpersonal yang dikemukakan beberapa ahli, yaitu:

Blake and Haroldsen mendefinisikan komunikasi interpersonal merupakan komunikasi dari mulut ke mulut ke mulut yang terjadi dalam interaksi langsung atau tatap muka antara beberapa pribadi dengan menggunakan bahasa verbal dan non verbal.(Blake and Haroldsen).

Sedangkan menurut Supratiknya, komunikasi Interpersonal merupakan suatu bentuk komunikasi baik verbal ataupun non verbal antara dua orang atau lebih dengan feedback seketika. (Supratiknya, 1995)

Komunikasi interpersonal adalah interaksi tatap muka antar dua atau beberapa orang, di mana pengirim dapat menyampaikan pesan secara langsung, dan penerima pesan dapat menerima dan menanggapi secara langsung pula. (Agus $\mathrm{M}$. Hardjana, 2003)

Komunikasi interpersonal pada masing-masing orang berbeda tingkat kedalaman komunikasinya, tingkat intensifnya, dan ekstensifnya. Komunikasi interpersonal antara dua orang kenalan berbeda dari komuniksi interpersonal antar sahabat juga antara guru dan siswa.

Komunikasi interpersonal merupakan kegiatan dinamis (Agus M. Hardjana, 2003). Dengan memperhatikan 
kedinamisannya, komunikasi interpersonal mempunyai cirri-ciri sebagai berikut:

1. Komunikasi interpersonal adalah verbal dan non verbal Komunikasi interpersonal adalah komunikasi yang pesannya dikemas dalam bentuk verbal dan nonverbal. Dalam komunikasi itu, seperti komunikasi pada umumnya, selalu mencakup dua unsur pokok: isi pesan dan bagaimana isi itu dikatakan atau dilakukan, baik secara verbal maupun non verbal.

2. Komunikasi interpersonal menyangkut perilaku tertentu Perilaku dalam komunikasi meliputi perilaku verbal dan non verbal. Ada tiga perilaku dalam komunikasi interpersonal, yaitu : pertama, perilaku spontan (spontaneous behaviour) adalah perilaku dilakukan karena desakan emosi dan tanpa sensor serta revisi secara kognitif. Kedua, perilaku menurut kebiasaan (script behaviour) adalah perilaku yang dipelajari dari kerbiasaan diri sendiri. Perilaku itu khas, dilakukan pada situasi tertentu, dan dimengerti orang. Misalnya ucapan 'apa kabar' pada waktu berjumpa dengan teman. Ketiga, perilaku sadar (contrived behaviour) adalah perilaku yang dipilih karena dianggap sesuai dengan situasi yang ada. Perilaku itu dipikirkan dan dirancang sebelumnya, dan disesuaikan dengan orang yang akan dihadapi, 
urusan yang akan diselesaikan, dan situasi serta kondisi yang ada.

3. Komunikasi interpersonal adalah yang berproses pengembangan Komunikasi interpersonal merupakan komunikasi yang berproses pengembangan (development process). Komunikasi interpersonal berbeda-beda tergantung dari tingkat hubungan pihak-pihak yang terlibat dalam komunikasi, pesan yang dikomunikasikan dan cara pesan dikomunikasikan.

4. Komunikasi interpersonal mengandung umpan balik, interaksi, dan koherensi.

Komunikasi interpersonal merupakan komunikasi tatap muka, sehingga kemungkinan umpan balik (feedback) besar sekali. Penerima pesan dapat langsung menanggapi dengan menyampaikan umpan balik. Dengan demikian, di antara pengirim dan penerima pesan terjadi interaksi (interaction) yang satu mempengaruhi yang lain, dan kedua-duanya saling mempengaruhi dan memberi serta menerima dampak. Agar komunikasi interpersonal itu berjalan secara teratur, dalam komunikasi itu pihak-pihak yang terlibat saling menanggapi sesuai dengan isi pesan yang diterima. Dari sini terjadilah koherensi dalam komunikasi baik antara pesan yang 
disampaikan dan u mpan balik yang diberikan, maupun dalam keseluruhan komunikasi.

5. Komunikasi interpersonal berjalan menurut peraturan tertentu Komunikasi interpersonal hendaknya mengikuti peraturan (rules) tertentu, baik intrinsik maupun ekstrinsik. Peraturan intrinsik adalan peraturan yang dikembangkan oleh masyarakat untuk mengatur cara orang harus berkomunikasi satu sama lain, yang menjadi patokan perilaku dalam komunikasi interpersonal. Peraturan ekstrinsik adalah peraturan yang ditetapkan oleh situasi atau masyarakat, dan sering menjadi pembatasan komunikasi. Misalnya, komunikasi interpersonal di rumah ibadah berbeda dengan komunikasi di lapangan bola.

6. Komunikasi interpersonal adalah kegiatan aktif Komunikasi interpersonal merupakan komunikasi timbal balik antara pengirim dan penerima pesan. Pihak-pihak yang berkomunikasi tidak hanya saling bertukar produk tetapi terlibat dalam proses untuk bersama-sama membentuk dan menghasilkan produk.

7. Komunikasi interpersonal saling mengubah

Melalui interaksi dalam komunikasi, pihak-pihak yang terlibat komunikasi dapat saling memberi inspirasi, semangat dan 
dorongan untuk mengubah pemikiran, perasaan, dan sikap yang sesuai dengan topik yang dibahas bersama.

Adapun efektifitas komunikasi interpersonal dimulai dengan kualitas umum yang dipertimbangkan yaitu; keterbukaan, empati, sikap mendukung, sikap positif, dan kesetaraan. (Devito, 1997)

\section{B. Komunikator yang Mendidik untuk Penguatan Karakter Siswa}

Mengelola kelas dan memecahkan konflik secara konstruktif membutuhkan keterampilan komunikasi efektif. Untuk itu, guru seharusnya menjadi komunikator pembelajaran yang baik.

Sebuah Penelitian tentang Kemahiran Komunikasi Guru Pelatih University Sains Malaysia (Communication Skills Among Training Teachers of University Sains Malaysia), dilakukan Nor Shafrin Ahmad, et.all,. Penelitian ini bertujuan untuk mengenal aspek komunikasi verbal dan non-verbal di kalangan guru pelatih, Pusat Pengkajian Ilmu Pendidikan, Universiti Sains Malaysia (USM), yang mengikuti program latihan mengajar. Aspek komunikasi verbal yang dikaji meliputi intonasi suara, kejelasan sebutan, dan kelancaran guru dalam menyampaikan bahan pengajaran. Aspek komunikasi non verbal meliputi ekspresi muka, kontak mata dan sentuhan.

Menurut Mohd. Safar dan Fatimah (1988) komunikasi verbal dan non verbal merupakan satu kesatuan yang tidak dapat 
dipisahkan. Antara satu dan lainnya berkaitan dalam menyampaikan sesuatu pesan. Maka dari itu, dalam melaksanakan proses pembelajaran guru harus mampu menggabungkan kedua jenis komunikasi ini.

Abdorrakhman Gintings menjelaskan hal-hal yang harus dilakukan guru dalam membangun komunikasi yang kondusif dalam pembelajaran adalah guru harus menguasai kompetensi komunikasi, yaitu:

1. Kemampuan menggunakan bahasa pengantar yang baik, benar, efektif, efesien serta disesuaikan dengan tingkat kemampuan siswa. Kemampuan bahasa ini diperlukan dalam mengemas pesan agar mudah dipahami oleh siswa dan sebaliknya, memahami pesan yang disampaikan siswa.

2. Mengatur irama suara melalui pengaturan variasi nada, volume, dan kecepatan, sehingga tidak membosankan siswa. Kebosanan akibat penyampaian materi dengan suara datar dan monoton akan sangat dirasakan siswa terutama ketika guru menyampaikan materi dengan kompleksitas tinggi atau pada waktu menjelang pelajaran usai.

3. Menggunakan bahasa non verbal seperti gerakan tubuh (body language) atau gesture dan movement serta ekspresi lainnya untuk memberikan kesan dan tekanan pada materi penting yang 
disampaikan. Dengan dukungan bahasa nonverbal, maka lebih banyak alat indera siswa yang diaktifkan dan dengan sendirinya semakin banyak sajian materi sajian yang terserap oleh siswa. (Abdorrakhman Gintings, 2008)

Sebagaimana penelitian yang dilakukan Mohammad Thoriq Hasan, dia melakukan penelitian untuk mengetahui pemahaman mahasiswa tentang komunikasi non verbal yang belum disadari urgensinya oleh para guru dan praktisi pendidikan lainnya di Pakistan. Dalam penelitian ini juga memberikan feedback kepada para guru muda di Pakistan yang berpihak terhadap inovasi dan refleksi pembelajaran serta mencoba menemukan pentingnya komunikasi non verbal bagi guru.

Peran komunikasi non verbal dalam dunia pendidikan tidak sepenuhnya disadari dan diterapkan oleh guru. Padahal, dengan komunikasi non verbal guru dapat lebih enjoy dan menghemat energy dalam berkata-kata. Siswa juga dapat terlibat dan termotivasi serta mendapatkan kebebasan dalam proses diskusi dalam kelas.

Keterampilan komunikiasi non verbal yang harus dikuasai guru diantaranya; body language, penggunaan kontak pandang, jarak berdiri dengan siswa, sentuhan. Menurut Balzer, dalam sebuah penelitiannya menyebutkan, bahwa pengelolaan kelas hampir 75\% menggunakan non verbal.

Penelitian Thariq menghasilkan temuan, bahwa penggunaan komunikasi non verbal yang kurang tepat dapat mengakibatkan siswa depresi dan gagal dalam ujian. Dia kemudian mengemukakan bahwa perlu ada pelatihan yang tepat 
dalam penggunaan komunikasi non verbal bagi guru. (Muhammad Thariq Hasan,2007)

Dalam pandangan Santrock, tiga aspek utama dari komunikasi adalah keterampilan komunikasi verbal, mendengar, dan komunikasi non verbal (John W. Santrock, 2004).

Guru dan siswa akan memperoleh banyak manfaat jika memiliki keterampilan komunikasi verbal dan guru bekerjasama dengan siswa untuk mengembangkan keterampilan komunikasi verbal mereka. Menurut Santrock, ada beberapa strategi untuk dapat berkomunikasi verbal di depan kelas (Santrock, 2004), yaitu:

1. Berbicara di depan kelas dan siswa. Dalam berbicara di depan kelas dan siswa, salah satu hal penting yang harus diingat adalah mengomunikasikan informasi secara jelas. Kejelasan (clarity) dalam berbicara sangat penting agar pengajaran berjalan baik. Strategi untuk berbicara secara jelas dengan kelas antara lain (Florez, 1999): menggunakan tata bahasa dengan benar, memilih kosakata yang gampang dipahami dan tepat bagi level grade siswa, Menerapkan strategi untuk meningkatkan kemampuan siswa dalam memahami apa yang dikatakan guru, berbicara dengan tempo yang tepat, tidak menyampaikan hal-hal yang kabur, menggunakan perencanaan dan pemikiran logis sebagai dasar untuk berbicara secara jelas di kelas. 
2. Bersikap asertif (tegas). Guru dengan gaya asertif dapat mengekspresikan perasaannya, meminta apa yang dia inginkan, dan berkata tidak untuk apa yang dia tidak inginkan. Ketika guru bertindak tegas, dia bertindak demi kepentingan dirinya yang terbaik. Guru yang asertif bersikeras agar perilaku yang salah harus diperbaiki, dan dia menolak untuk dipaksa atau dimanipulasi (Evertson, Emmer, \& Worsham, 2003). Menurut Robert Alberti dan Michael Emmons (1995), assertiveness bisa menciptakan hubungan yang positif dan konstruktif.

Mengelola kelas akan lebih mudah dan efektif jika guru dan siswa memiliki keterampilan mendengar yang baik. Mendengar adalah keahlian penting dalam menjalin dan menjaga hubungan. Jika guru memiliki keterampilan mendengar yang baik, maka siswa, orang tua, guru lain dan administrator akan tertarik dengan dirinya. Jika siswa adalah pendengar yang baik, mereka akan mendapat manfaat dari pengajaran dan mereka akan memiliki hubungan sosial yang lebih baik.

Beberapa strategi mengembangkan keterampilan mendengar aktif (Santrock \& Halonen, 2002) yaitu: Memberikan perhatian cermat pada orang yang sedang berbicara, menggunakan prafrasa, mensintesiskan tema dan pola, serta memberikan umpan balik atau tanggapan dengan cara yang kompeten.

Selain apa yang dikatakan (verbal), komunikasi juga dilakukan melalui tangan, tatapan mata, menggerakkan mulut, menyilangkan kaki, atau menyentuh orang lain. Beberapa contoh 
perilaku umum yang dilakukan dalam komunikasi non verbal (Santrock, 2004), :

1. Mengangkat alis sebagai tanda tidak percaya

2. Bersedekap untuk melindungi diri

3. Mengangkat bahu sebagai tanda tidak peduli

4. Mengedipkan satu mata untuk menunjukkan kehangatan dan persetujuan

5. Mengetukkan jari tanda tidak sabar, dan

6. Menepuk dahi tanda lupa sesuatu

Banyak pakar komunikasi percaya bahwa sebagian besar komunikasi interpersonal dilakukan secara non verbal. Bahkan orang duduk di sudut ruangan sambil membacakan buku sebenarnya sedang mengkomunikasikan sesuatu secara nonverbal, mungkin mereka sedang ingin sendirian. Saat ada siswa menatap kosong ke jendela dengan tatapan kosong, mungkin mengindikasikan bahwa mereka sedang bosan.

\section{Komunikasi Pendidikan}

Pada dasarnya seorang guru adalah seorang komunikator. Proses pembelajaran yang dilakukan di dalam kelas merupakan proses komunikasi. Dalam konteks komunikasi pendidikan, guru harus memiliki prasyarat komunikasi yang efektif dalam menyampaikan pesan pembelajaran.

Komunikasi adalah sebuah proses terus menerus yang terjadi antara pengirim dan penerima pesan yang terjadi pada 
manusia untuk berbagi pengetahuan, sikap, dan keterampilan. Dalam pembelajaran yang efektif tergantung pada efektifitas komunikasi. Pada saat guru dan siswa berinteraksi, maka sedang terjadi komunikasi eksplisit dan implisit. (Pattrick w. Miller, 5)

Komunikiasi pendidikan memiliki batasan tujuan untuk mengajar dan memenej kelas (Richard A. Fiordo, 2010). Komunikasi pendidikan mencoba untuk mencapai keseluruhan materi dan perilaku yang tepat dalam pembelajaran. Dengan kata lain, komunikasi pendidikan adalah pembelajaran yang setiap komponennya memiliki makna interaksi dengan komunikatornya.

Komunikasi pendidikan juga diartikan sebagai proses perjalanan pesan atau informasi yang merambah bidang atau peristiwa-peritiwa pendidikan. Maka komunikasi dalam pendidikan tidak lagi bebas dan netral, tetapi dikendalikan dan dikondisikan untuk tujuan-tujuan pendidikan (Pawit M. Yusuf, 2010)

Mengelola kelas dan memecahkan konflik secara konstruktif membutuhkan keterampilan komunikasi efektif. Untuk itu, guru seharusnya menjadi komunikator pembelajaran yang baik. Banyak tipe komunikasi diantaranya; komunikasi intrapersonal, interpersonal, publik, media, organisasi, interkultural, dan massa. Komunikasi interpersonal lebih lazim diterapkan dalam kelompok kecil termasuk kelas.

Salah satu definisi komunikasi interpersonal yang dikemukakan oleh ahli, yaitu: Blake and Haroldsen 
mendefinisikan komunikasi interpersonal merupakan komunikasi dari mulut ke mulut ke mulut yang terjadi dalam interaksi langsung atau tatap muka antara beberapa pribadi dengan menggunakan bahasa verbal dan non verbal.(Blake and Haroldsen, 2002).

Komunikasi interpersonal pada masing-masing orang berbeda tingkat kedalaman komunikasinya, tingkat intensifnya, dan ekstensifnya. Komunikasi interpersonal antara dua orang kenalan berbeda dari komuniksi interpersonal antar sahabat juga antara guru dan siswa.

Dalam dunia pendidikan, komunikasi menjadi kunci yang cukup determinan dalam mencapai tujuan. Seorang guru, betapapun pandai dan luas pengetahuannya, jika tidak mampu mengkomunikasikan pikiran, pengetahuan, dan wawasannya, tentu tidak akan mampu memberikan transformasi pengetahuannya kepada para siswa. Seorang guru dalam kelas harus memikirkan bentuk komunikasi yang efektif agar pesan yang disampaikan dapat tepat sasaran dan mencapai hasil optimal sebagaimana diharapkan.

Menurut Steven A. Meyers (2009), bentuk-bentuk komunikasi interpersonal yang dapat dilakukan guru ada 2, kedekatan secara verbal dan kedekatan secara fisik. Berikut contoh-contohnya: 


\begin{tabular}{|l|l|}
\hline katan secara Verbal & ekatan secara fisik \\
\hline eritakan pengalaman yang terjadi di & hat keseluruhan kelas ketika berbicara, \\
kelas, memberikan pertanyaan atau um saat berbicara, ketika mengajar \\
lorong siswa untuk bertanya, & berdiam di satu tempat, posisi badan \\
ggunakan humor di dalam kelas, & saat mengajar, tersenyum pada siswa \\
anggil siswa dengan namanya, a individual di dalam kelas, \\
kap-cakap dengan siswa secara ggunakan ragam ekspresi suara ketika \\
idu sebelum atau selesai \\
pelajaran, memberikan umpan balik \\
-tugas siswa, menanyakan kepada \\
a tentang tugas-tugas sekolah, \\
gundang siswa untuk bertemu di luar \\
pelajaran jika mereka ingin bertanya \\
ng sesuatu ataumendiskusikan tentang \\
tu, bertanya untuk membangun opini \\
l, menghargai kerja siswa melalui \\
kan atau komentar, mendiskusikan \\
tu yang tidak ada kaitannya dengan \\
ri kelas baik secara individu atau \\
uruhan siswa.
\end{tabular}




\section{DAFTAR PUSTAKA}

Ahmad Fuadi Romadhon, Achyar Zein, Syamsu Nahar. 2017. Nilai-Nilai

Pendidikan Karakter Dalam Al-Qur'an Surat Yusuf, Edu Riligia.

Pascasarjana UIN Sumatera Utara. Vol. 1 No. 3.

Alwazir Abdusshomad. 2020. Pengaruh Covid-19 terhadap Penerapan Pendidikan Karakter dan Pendidikan Islam. Politeknik Penerbangan Indonesia Curug, Tangerang. Qalamuna - Jurnal Pendidikan, Sosial, dan Agama | Vol. 12 No. 2 (2020) 107-115

Andrew,et al., 2005. Verbal Ability and Teacher Effectiveness, Journal of Teacher Education.

Azmi, Nailul. 2017. Manajemen Pendidikan Karakter Siswa MAN 1 Brebes dan MAN 2 Brebes. Thesis. Program Studi Manajemen Pendidikan Islam. Pascasarjana Institut Agama Islam Negeri Purwokerto

Basher, Abdul. 2018. "Nilai-Nilai Pendidikan Karakter Islami Dalam Buku Hoegeng Polisi dan Menteri Teladan”. Skripsi. Fakultas Ilmu Tarbiyah dan Keguruan. Pendidikan Agama Islam. Institut Agama Islam Negeri Surakarta

Brucea, M.A. \& Stellern, J. 2005. Building Caring Community in Teacher Education, Journal of The Teacher Educator, 41 (1), 34-53. 
Budiyono1; Yoga Ardian Feriandi2. 2017. Menggali Nilai Nilai Kearifan Lokal Budaya Jawa Sebagai Sumber Pendidikan Karakter. FKIP Universitas PGRI Madiun . Prosiding SNBK (Seminar Nasional Bimbingan dan Konseling) Vol. 1 No.1 (Mei 2017) Online ISSN 2580-216X

Byham, W. C., \& Pescuric, A. 1996. Behavior Modeling at the teachable moment. Training, 33, 50-53.

Chairiyah. 2014. Revitalisasi Nilai-Nilai Pancasila Sebagai Pendidikan Karakter. Universitas Sarjanawiyata Tamansiswa. Trihayu : Jurnal Pendidikan Ke SD an Vol. 1, Nomor 1, September 2014, hlm 54-62

Darn, Steve., Aspects of Nonverbal Communication, The Internet TESL Journal, Vol.XI, No.2, 2005

Decker, Philip J., 1984, Behavior Modeling Training, New York USA: CBS Educational and Professional Publishing

Eryilmaz, Dilek \& Darn, Steve., A Non Verbal Communication Lesson, Izmir University of Economics, 2005

Fry, John.P. \& Dede Bonner, 2001, Models and Strategies for Training Design, (edited by: Karen L. Medsker \& Kristina M. 
Holdsworth), USA: International Society for Performance Improvement (ISPI)

McCroskey, J.C. 1992. An Introduction to Communication in The Classroom. Edina, MN: Burgess International Group.

Miftah Nurul Annisa, Ade Wiliah, Nia Rahmawati. 2020. Pentingnya Pendidikan Karakter Pada Anak Sekolah Dasar di Zaman Serba Digital . Universitas Muhammadiyah Tangerang . Jurnal Pendidikan dan Sains Volume 2, Nomor 1, April 2020; 35-48 https://ejournal.stitpn.ac.id/index.php/bintang

Miller, S. A. \& Anderson, E. S. 2009. Modeling and measuring Caring Behaviors among Nursing Education Faculty. Journal of Nursing Education, 32.

Muhammad Sulhan. 2018. Pendidikan Karakter Berbasis Budaya Dalam Menghadapi Tantangan Globalisasi. Universitas Indraprasta PGRI. Jurnal VisipenaVolume 9, Nomor 1, Juni 2018

Mustoip, sofyan, Muhammad Japar, zulela Ms. 2018. Implementasi Pendidikan Karakter. CV. Jakad Publishing Surabaya

Nafiah, Wasilatun. 2019. Manajemen Pendidikan Karakter (Studi Kasus di Smp Muhammadiyah 2 Malang). Thesis. Program Magister Manajement Pendidikan Islam Pascasarjana Universitas Islam Negeri Maulana Malik Ibrahim Malang 
NKongho, N. 1994. The Caring Ability Inventory. In O.L.

Strickland \& C.R. Waltz (Eds.), Measurement of Nursing Outcomes (4). New York: Springer Publishing.

Noddings, N. 2001. The Caring Teacher. Dalam V. Richardson (Ed.), Handbook of research on teaching ( $4^{\text {th }}$ ed., pp.99-105). Washington, DC: American Educationala Research Association.

Noddings, N., Michael S. K. \& Kenneth A. S. 1999. Justice and Caring, the Search for Common Ground in Education. New York: Teachers College Press.

Noddings, N. 1993. Educating for Intelligent Belief or Unbelief. New York: Teacher College Press.

Noddings, N. 1992. The challenge to Care in School. New York: Teachers College Press.

Noddings, N. 1984. Caring a Feminine Approach to Ethics and Moral Education, Barkeley: University of California Press.

Noddings, N. 2001. The Caring Teacher. Dalam V. Richardson (Ed.), Handbook of research on teaching ( $4^{\text {th }}$ ed., pp.99-105). Washington, DC: American Educationala Research Association

Nopan Omeri. 2015. Pentingnya Pendidikan Karakter Dalam Dunia Pendidikan. SMA Negeri 1 Arga Makmur. Volume 9, Nomor 3, Juli 2015, hlm. 464-468 
Palmer, P.J. 1998. The Courage to Teach. San Fransisco: Jossey-Bass.

Paul, J. T. \& Darlene F. R.E. 2005. Jurnal of Applied Psychology, 90(4), 113-124.

Putra, Bil Hakki., 2014. Teknik Evaluasi Pendidikan Karakter Pada Mata Pelajaran Pendidikan Agama Islam di Sekolah Menengah Pertama Negeri 1 Pekanbaru. Skripsi thesis, Universitas Islam Negeri Sultan Syarif Kasim Riau

Ristanti, Dini Hadi. 2019. Pendidikan Karakter Berbasis Budaya Sekolah (Studi Kasus Di Smp Negeri 30 Dan Smpit Ash-Shiddiq Jakarta Utara). Tesis. Program Magister Manajemen Pendidikan Islam Fakultas Ilmu Tarbiyah Dan Keguruan Uin Syarif Hidayatullah Jakarta

Robinson, J.C. 1982. Developing Managers Through Behavior Modeling. Austin, TX: Learning Concepts.

Rogers, D. L. 1994. Conceptions of Caringin a fourth grade classroom. dalam A. R. Prillaman, D. J. Eaken and D. M.Kendrick (Eds) The apestry of Caring. Norwood,NJ: Ablex Publishing.

Rogers, D. L., \& Webb, J. 1991. The ethic of Caring in teacher education. Journal of Teacher Education, 42(3), 173-181. 
Ronald, Schmidt \& Fajlik, Ibaraki., 2007. Introducing non verbal Communication to Japanese University Students: Determining Content, Univ. Japan. Journal of Intercultural Communication.

Rohendi, Edi. 2016 .Pendidikan Karakter di Sekolah. Edu Humaniora Jurnal Pendidikan Dasar Kampus Cibiru Vol 3, No 1

Samrin. 2016. Pendidikan Karakter (Sebuah Pendekatan Nilai). Dosen Fakultas Tarbiyah dan Ilmu Keguruan IAIN Kendari. Jurnal AlTa'dib Vol. 9 No. 1, Januari-Juni.

Sofia Ratna, Awaliyah Fitri, Tanto Aljauharie Tantowie. 2016 .Nilai-Nilai Pendidikan Karakter Dalam Al-Quran Surah Al-An'am Ayat 151153 dan Implementasinya Dalam Pembelajaran Pendidikan Agama Islam (Studi Analisis terhadap Tafsir Al-Munir Karya Wahbah Az-Zuhaili), Tarbiyah al-Aulad ISSN 2549 4651, Volume 1, No. 1.

Subianto, Jito. 2013. Peran Keluarga, Sekolah, dan Masyarakat Dalam Pembentukan Karakter Berkualitas . LPPG (Lembaga Peningkatan Profesi Guru), Jawa Tengah, Indonesia Vol. 8, No. 2, Agustus 2013 
Sudarmiani. 2013. Membangun Karakter Anak Dengan Budaya Kearifan Lokal Dalam Proses Pembelajaran di Sekolah. IKIP PGRI Madiun

Sunhaji. 2018. Mendidik Melalui Hati Sebagai Strategi Membentuk Karakter Bangsa. Fakultas Tarbiyah dan Ilmu Keguruan IAIN Purwokerto .Jurnal Ilmiah Lingua Idea ISSN 2580-1066 (Online) ISSN 2086-1877 (Printed) Vol. 9 No. 2.

Supriyono. 2014. Membangun Karakter Mahasiswa Berbasis Nilai-Nilai Pancasila Sebagai Resolusi Konflik. Universitas Pendidikan Indonesia. Edutech, Tahun 13, Vol.1, No.3

Tariq Hassan, M. Muhammad., 2007. Non Verbal Communication: The Language of Motivation for Pakistani Students, Jurnal Language in India, volume 7.

Tuckman, B.W. 1999. Conducting Educational Research. New York: Harcourt Brace College Publisher.

Wachid, Nur. 2019. Implementasi Nilai-Nilai Pendidikan Karakter dalam Pembelajaran Pendidikan Agama Islam di SMA Negeri 1 Semarang Tahun Pelajaran 2018/2019. Skripsi. Fakultas Ilmu Tarbiyah dan Keguruan Universitas Islam Negeri (UIN) Walisongo Semarang

Wentzel, K. R. 1997. Student Motivation in Middle School: The Role of Perceived Pedagogical Caring. Journal of Educational Psychology, 89 (3), 411-419. 
Woolfolk, H. A., \& Weinstein, C. 2006. Student and Teacher perspectives on Classroom Management. New Jersey: Erlbaum.

Wolfgang Lorscher, 2002., Nonverbal aspects of Teacher-Pupil Communication in the Foreign Language Classroom, University of Leipzig Germany. 


\section{TENTANG PENULIS}

Akhtim Wahyuni lahir di desa Laren-Lamongan pada 20 Maret 1973 anak ke enam dari enam bersaudara, pasangan Bapak Saechanan (Alm.) dan Ibu Hj. Tadzkiroh. Menikah dengan Eko Sulis Budianto, dari Kediri . Pendidikan Dasar dan Menengah ditempuh SDN I Laren, MIM Laren, dan MTs. Muhammadiyah Laren, dan selanjutnya melanjutkan ke MA YTP Kertosono Nganjuk lulus tahun 1991. Selepas dari MA, melanjutkan S1 di fakultas Tarbiyah IAIN Sunan Ampel (sekarang UINSA) Surabaya, lulus tahun 1995.

Gelar Master diperolehnya pada tahun 2001 di UINSA. Tahun 2009, ia berkesempatan untuk melanjutkan program Doktor di Universitas Negeri Malang dengan beasiswa dari DIKTI lulus tahun 2014. Pendidikan non formal yang pernah diikuti yaitu; Pendidikan Pelatihan, kursus-kursus baik di dalam maupun di luar negeri.

Kariernya sebagai dosen tetap Universitas Muhammadiyah Sidoarjo dimulai tahun 2002. Sejak tahun 2004 menjadi dosen DPK di universitas yang sama sampai saat ini. Selain mengajar di UMSIDA, ia juga aktif di kegiatan Organisasi Kemasyarakatan. 
Tercatat aktif di Pimpinan Wilayah 'Aisyiyah Jawa Timur sejak tahun 2003, juga aktif di Majelis Pendidikan Dasar dan Menengah Pimpinan Wilayah Muhammadiyah Jawa Timur. Di samping itu, aktif juga di kegiatan penelitian, pengabdian kepada masyarakat, menjadi pembicara seminar, workshop, juga trainer di pelatihanpelatihan pendidikan. 
188N 978-823-6252-78-5 (PDF)

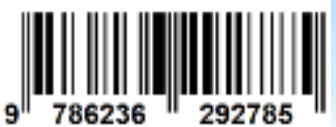

